\title{
Publications of the U.S. Geological Survey, Water Resources Division, for Puerto Rico and the U.S. Virgin Islands, 1899-1992
}

By Ruth I. Guzmán-Otero

U.S. GEOLOGICAL SURVEY

Open-File Report 93-629 


\title{
U.S. DEPARTMENT OF THE INTERIOR BRUCE BABBITT, Secretary
}

\author{
U.S. GEOLOGICAL SURVEY
}

Robert M. Hirsch, Acting Director

For additional information write to:

Caribbean District Chief

U.S. Geological Survey, WRD

GSA Center

651 Federal Drive, Suite 400-15

Guaynabo, Puerto Rico 00965
Copies of this report can be purchased from:

U.S. Geological Survey

Earth Science Information Center

Open-File Reports Section, MS 517

Box 25286, Denver Federal Center

Denver, CO 80225 


\section{CONTENTS}

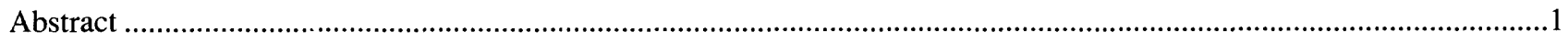

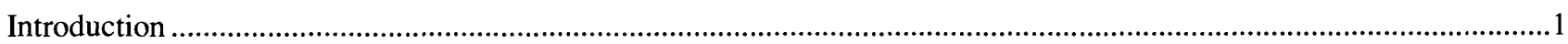

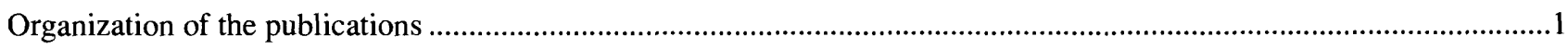

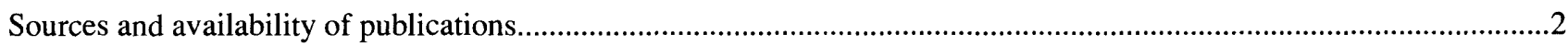

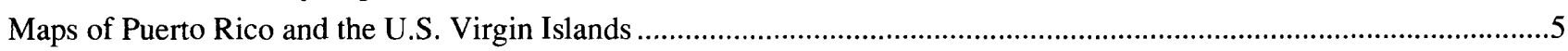

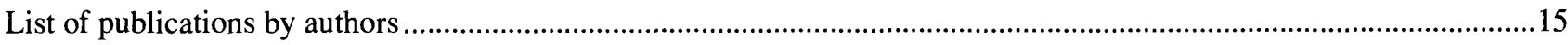

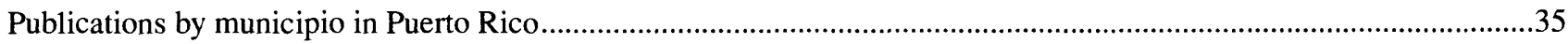

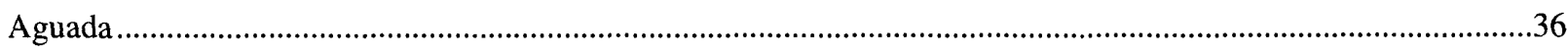

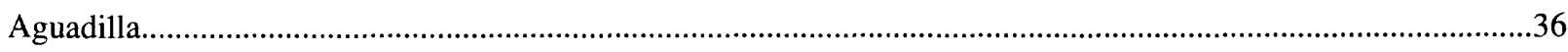

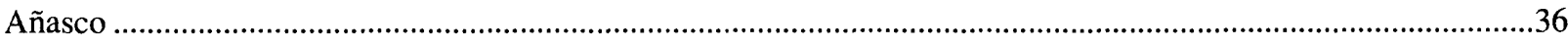

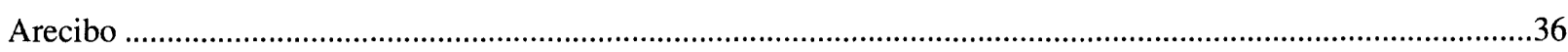

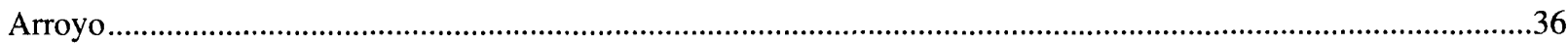

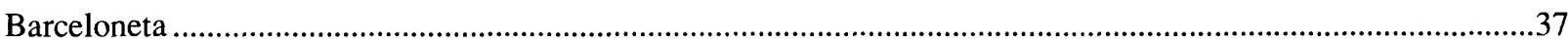

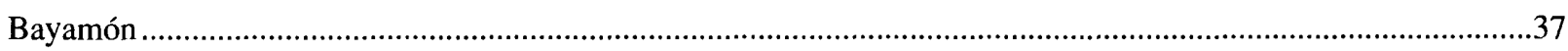

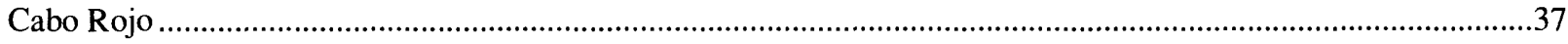

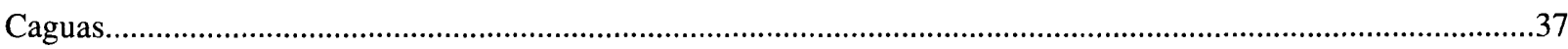

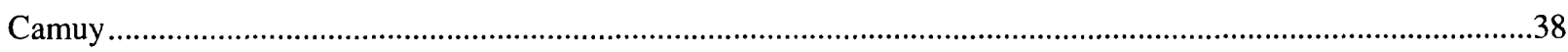

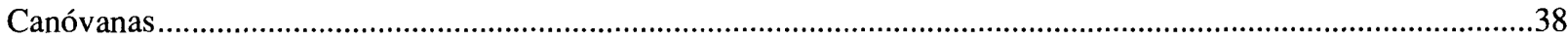

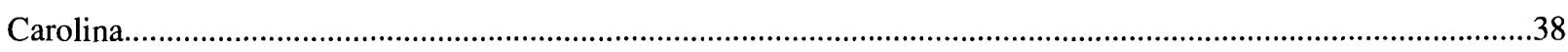

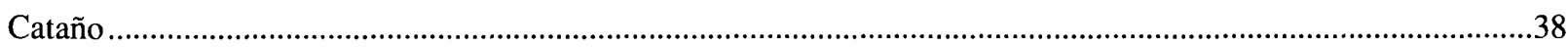

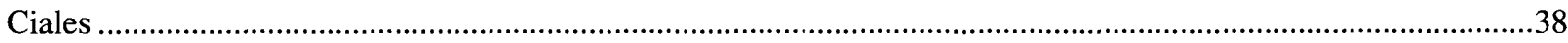

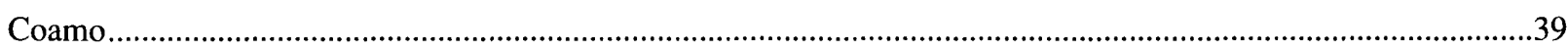

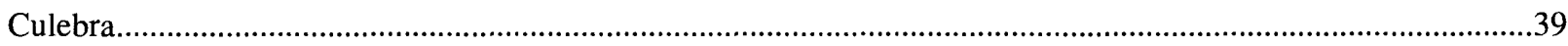

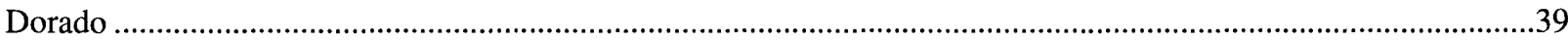

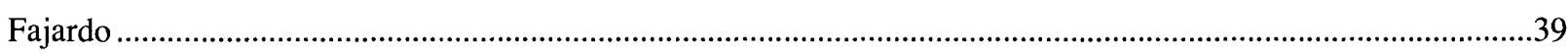

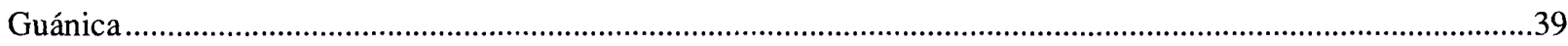

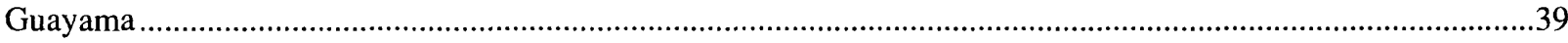

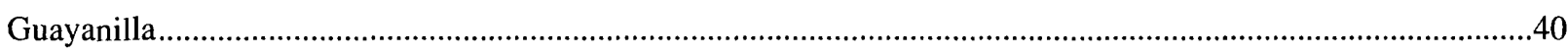

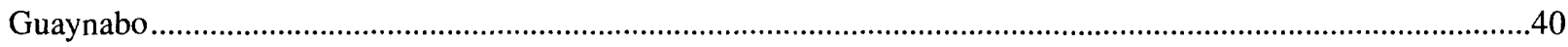

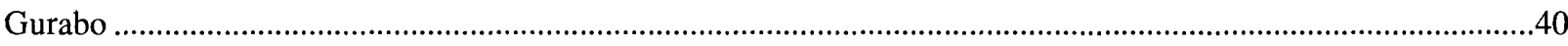

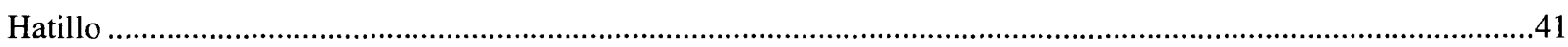

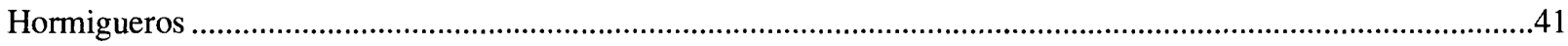

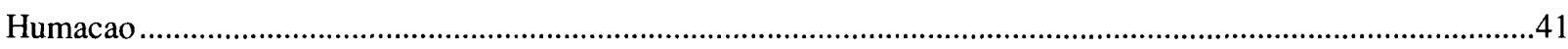

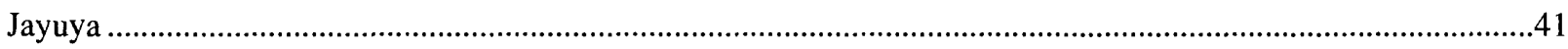

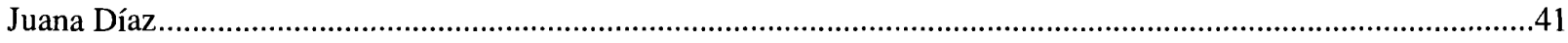

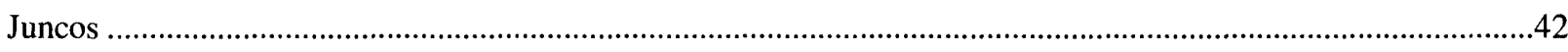

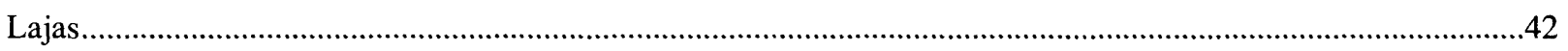




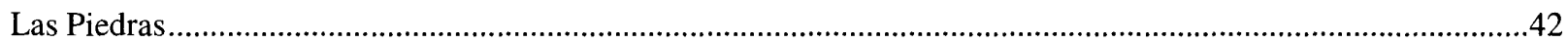

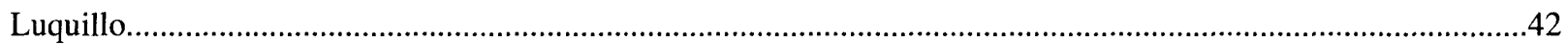

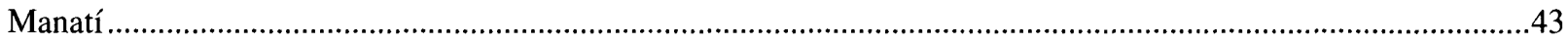

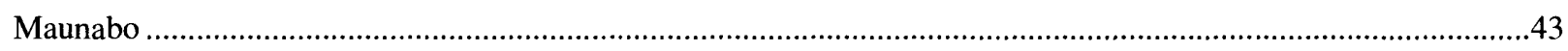

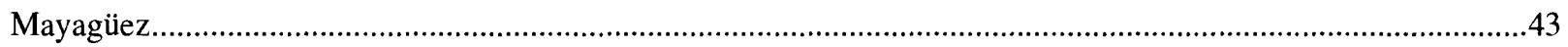

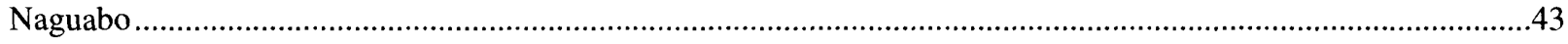

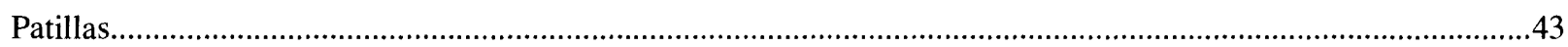

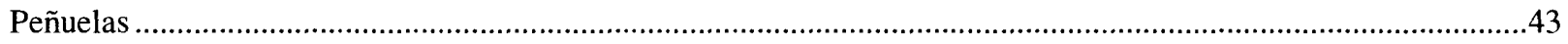

Ponce

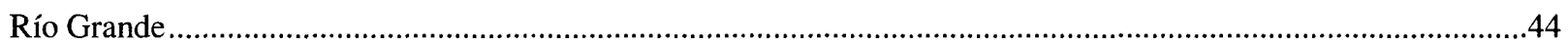

Sabana Grande

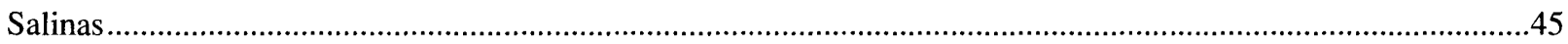

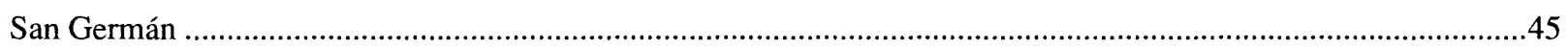

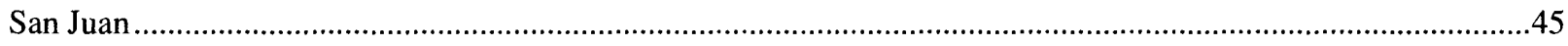

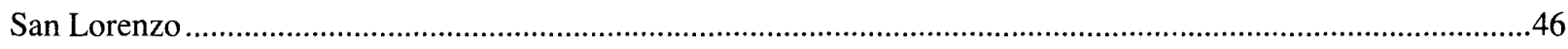

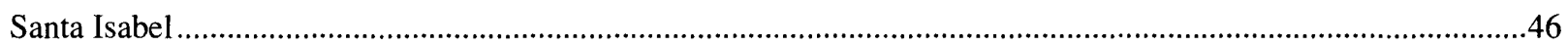

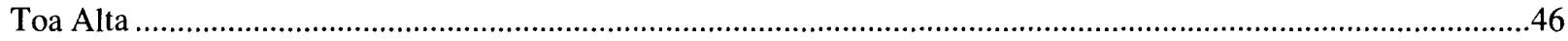

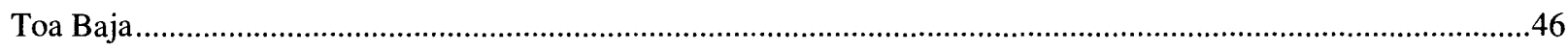

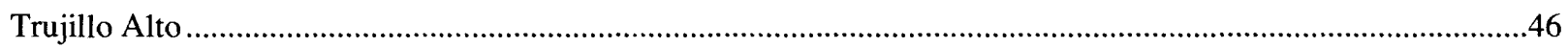

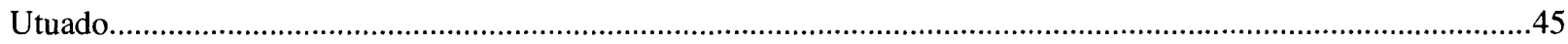

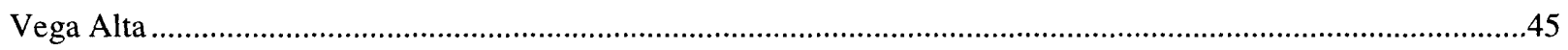

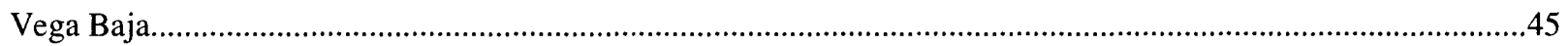

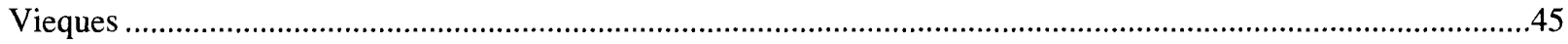

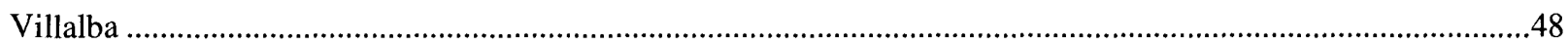

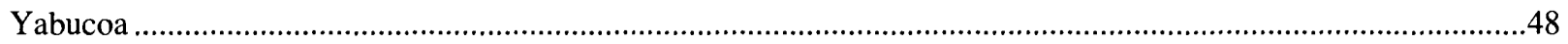

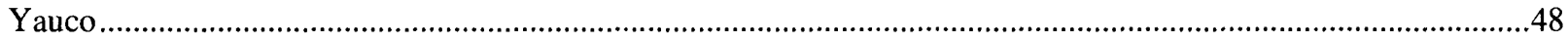

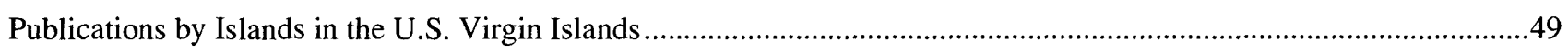

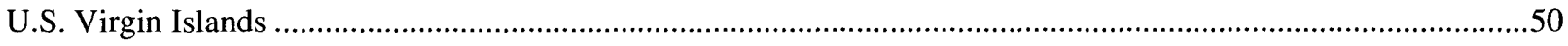

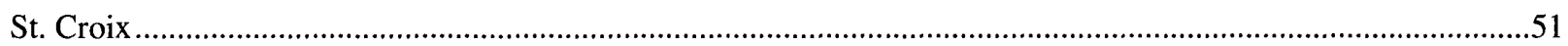

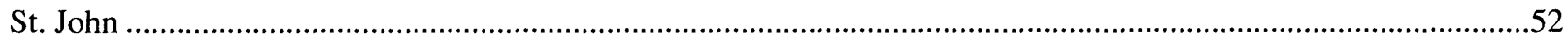

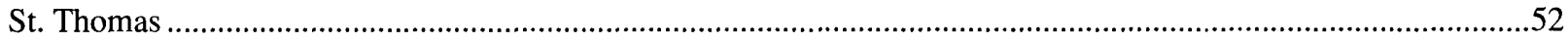

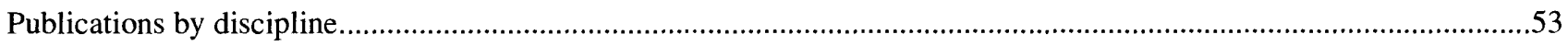

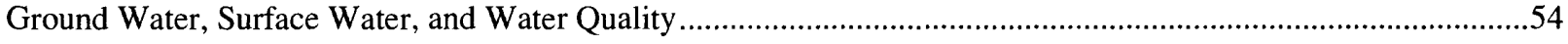

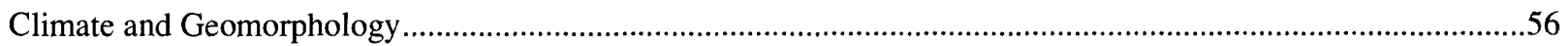

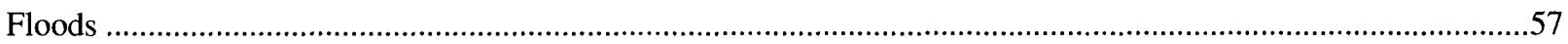

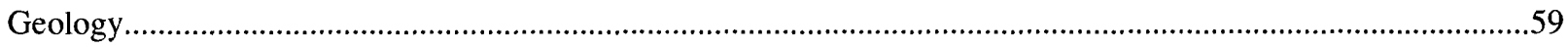

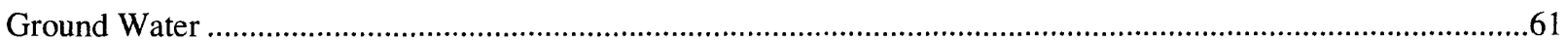

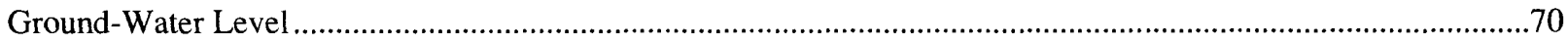




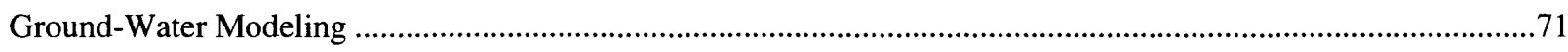

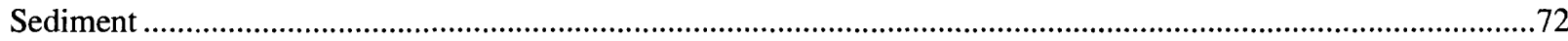

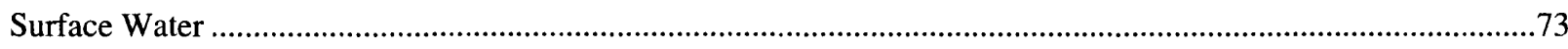

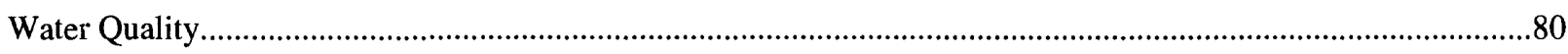

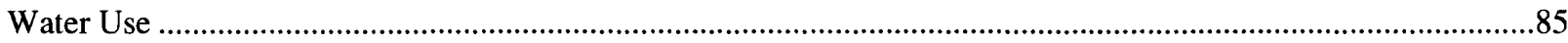

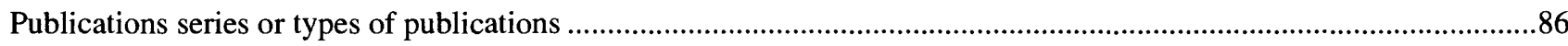

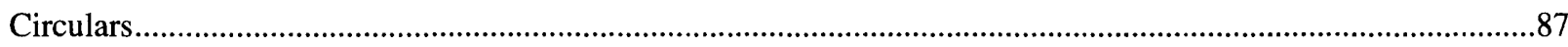

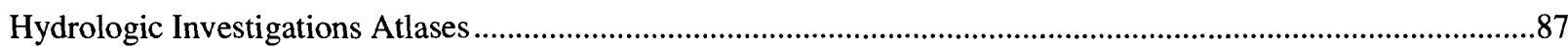

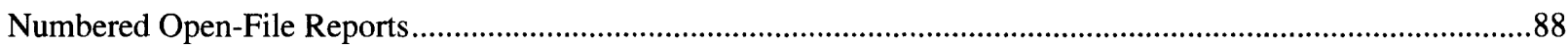

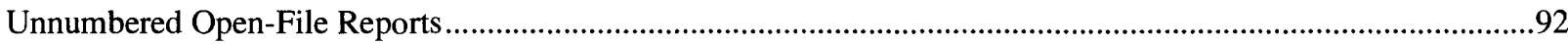

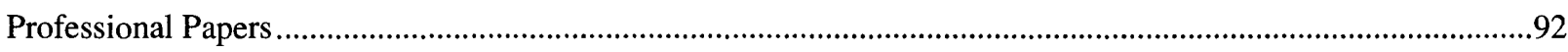

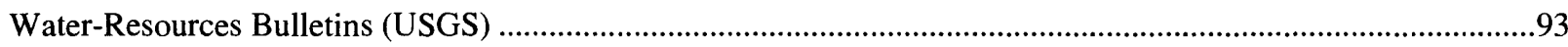

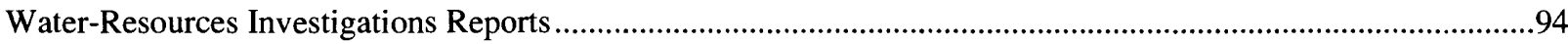

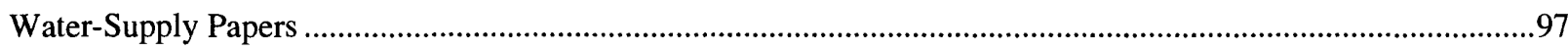

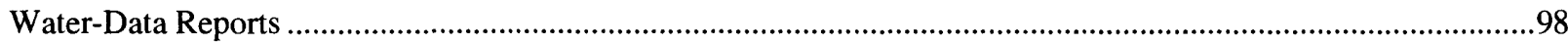

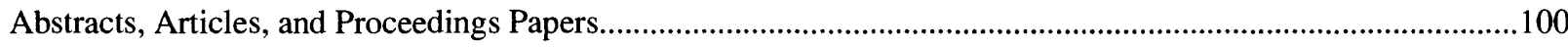

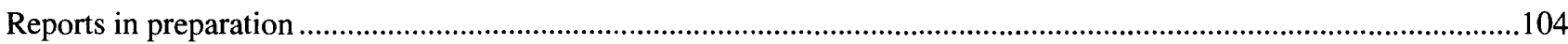

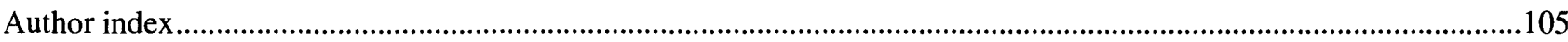

\section{ILLUSTRATIONS}

Figure 1-7. Map showing:

1. Location of the U.S. Geological Survey Caribbean District,

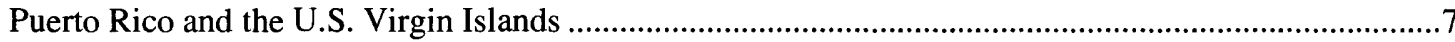

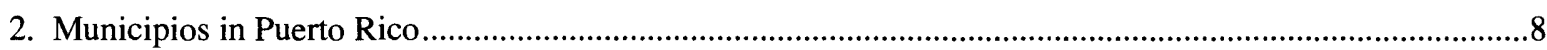

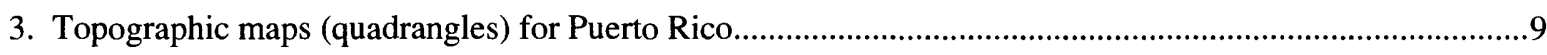

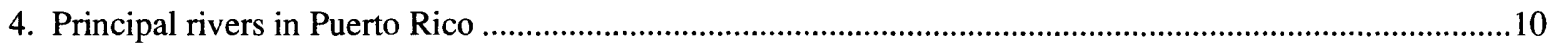

5. Principal streams in Culebra and Vieques, Puerto Rico.......................................................................11

6. Principal drainages in St. Thomas and St. John, U.S. Virgin Islands ..........................................................12

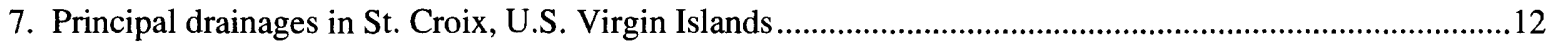

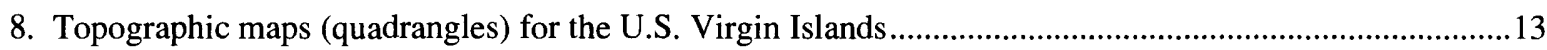




\title{
Publications of the U.S. Geological Survey, Water Resources Division, for Puerto Rico and the U.S. Virgin Islands, 1899-1992
}

\author{
By Ruth I. Guzmán-Otero
}

\begin{abstract}
A list of publications of the water-resources investigations conducted by the U.S. Geological Survey, Water Resources Division, for Puerto Rico and the U.S. Virgin Islands was compiled. The water-resources data and the results of the interpretive investigations and research are published by either the U.S. Geological Survey or cooperating agencies. This report lists all publications resulting from water-resources activities in Puerto Rico and the U.S. Virgin Islands from 1899 to 1992, and lists sources of publication information in the U.S. Geological Survey.
\end{abstract}

\section{INTRODUCTION}

The U.S. Geological Survey, Water Resources Division's mission is to provide the hydrologic information and understanding needed for the optimum utilization and management of the Nations water resources for the overall benefit of the people of the United States and its territories. The U.S. Geological Survey has conducted water-resources investigations in Puerto Rico and the U.S. Virgin Islands since 1899.

The U.S. Geological Survey Caribbean District office was established in Puerto Rico in 1957. Since then, almost all of the water-resources investigations conducted by the U.S. Geological Survey have been in cooperation with local agencies. The studies include data collection related to streamflow, ground-water levels, water-quality, sediment transport, water-use inventories, and areal water-resources appraisals. The results of these investigations are published in a variety of data and interpretive reports.

\section{ORGANIZATION OF THE PUBLICATIONS}

This report includes publications regarding water-resources information in Puerto Rico and the U.S. Virgin Islands released from 1899 to 1992 . The publications are grouped into four categories: by author(s), by specific locations in Puerto Rico and the U.S. Virgin Islands, by discipline of interest (climate and geomorphology, floods, geology, ground water, ground-water level, ground-water modeling, sediment, surface water, water quality, and water use), and publication by series or type. For the reader's information, a list of approved reports pending publication is included. As these reports are completed and printed, they will be available for distribution. 
For each publication the following information is presented: author(s), year of publication, title, publisher, type of publication, and number of pages. Publications in all categories are listed alphabetically by senior author, except for the section on types of publications, which are in numerical order. There is also a section entitled 'Maps of Puerto Rico and the U.S. Virgin Islands' which shows the location of the U.S. Geological Survey Caribbean District (fig. 1), the municipios in Puerto Rico (fig. 2), the topographic maps (quadrangles) for Puerto Rico (fig. 3), the principal rivers in Puerto Rico (fig. 4), the principal streams in Culebra and Vieques, Puerto Rico (fig. 5), the principal drainages in St. Thomas and St. John, U.S. Virgin Islands (fig. 6), the principal drainages in St. Thomas, U.S. Virgin Islands (fig. 7), and the topographic maps (quadrangles) for the U.S. Virgin Islands (fig. 8). The reader should refer to these figures when necessary to find a particular area. An index of authors is also included at the end of this report. To help make this report more useful to the user, it would be appreciated if discrepancies are noted and sent to the Caribbean District office mentioned below, so that corrections can be incorporated into the next edition.

\section{SOURCES AND AVAILABILITY OF PUBLICATIONS}

Many of the publications listed in this report may be available from the U.S. Geological Survey, Caribbean District office. Journal articles, proceedings papers, and abstracts by Geological Survey personnel in non-Geological Survey publications are not available from the U.S. Geological Survey. Inquiries concerning available publications can be made by writing to the following address:

\section{U.S. Gcological Survey, WRD GSA Center \\ 651 Iiederal Drive, Suitc 400-15 \\ Guaynabo, Pucrto Rico 00965}

The inquiry should include the author of the report, type and number, and the full title of the report. The Caribbean District office also maintains library copies of some of the out-of-print publications. Many of the listed publications are out-of-print and can be obtained only through the National Technical Information Services (NTIS) or from the U.S. Geological Survey Text Distribution Center:

\section{U.S. Geological Survey Publication Series}

Water-Resources Investigations Reports

Open-File Reports

Hydrologic Investigations Atlases

Topographic Maps (quadrangles)
Sources of Publications

U.S. Geological Survey

Earth Science Information Center

Open-File Reports Section

Box 25286, MS 517

Denver Federal Center

Denver, Colorado 80225

USGS Map Distribution

Box 25286, Building 810

Denver Federal Center

Denver, Colorado 80225 


\section{U.S. Geological Survey Publication Series}

Bulletins, Circulars, Leaflets

Professional Papers

Techniques of Water-Resources Investigations

Water-Supply Papers

Water-Data Reports
Sources of Publications

USGS Map Distribution

Box 25286, MS 306

Denver Federal Center

Denver, Colorado 80225

National Technical Information Service

U.S. Department of Commerce

5285 Port Royal Road

Springfield, Virginia 22161

Within Puerto Rico, topographic maps (quadrangles) may be obtained at the:

\author{
Highway Authority \\ Photogrammetry Office \\ Minillas South Building, Third Floor \\ Santurce, Puerto Rico
}

Questions about water resources in general or about the water resources of specific areas of the United States can be directed to the:

$$
\begin{gathered}
\text { Hydrologic Information Unit } \\
\text { U.S. Geological Survey } \\
420 \text { National Center } \\
\text { Reston, Virginia } 22092
\end{gathered}
$$

This office will also answer inquires about the availability of water-resources investigations reports.

The U.S. Geological Survey issues a list of "New Publications of the Geological Survey." A subscription to this monthly catalog is free by writing to the:

\author{
U.S. Geological Survey \\ 582 National Center \\ Reston, Virginia 22092
}


(BLANK) 
MAPS OF PUERTO RICO AND THE U.S. VIRGIN ISLANDS 


\section{(BLANK)}




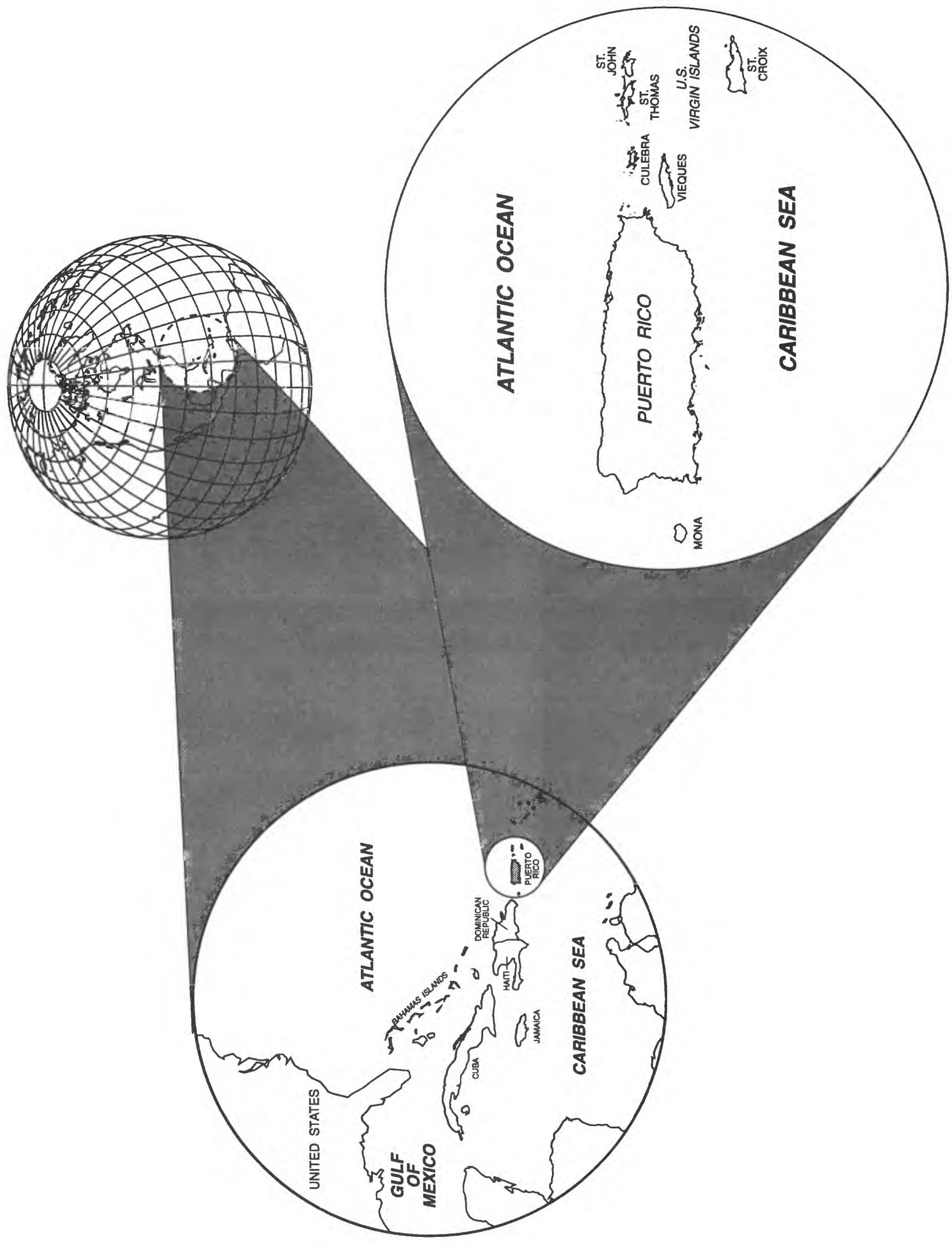

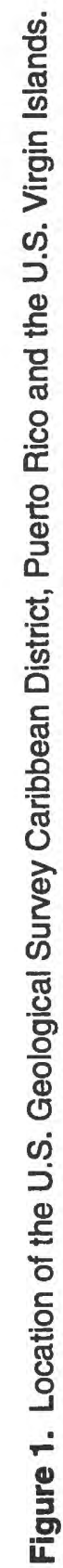




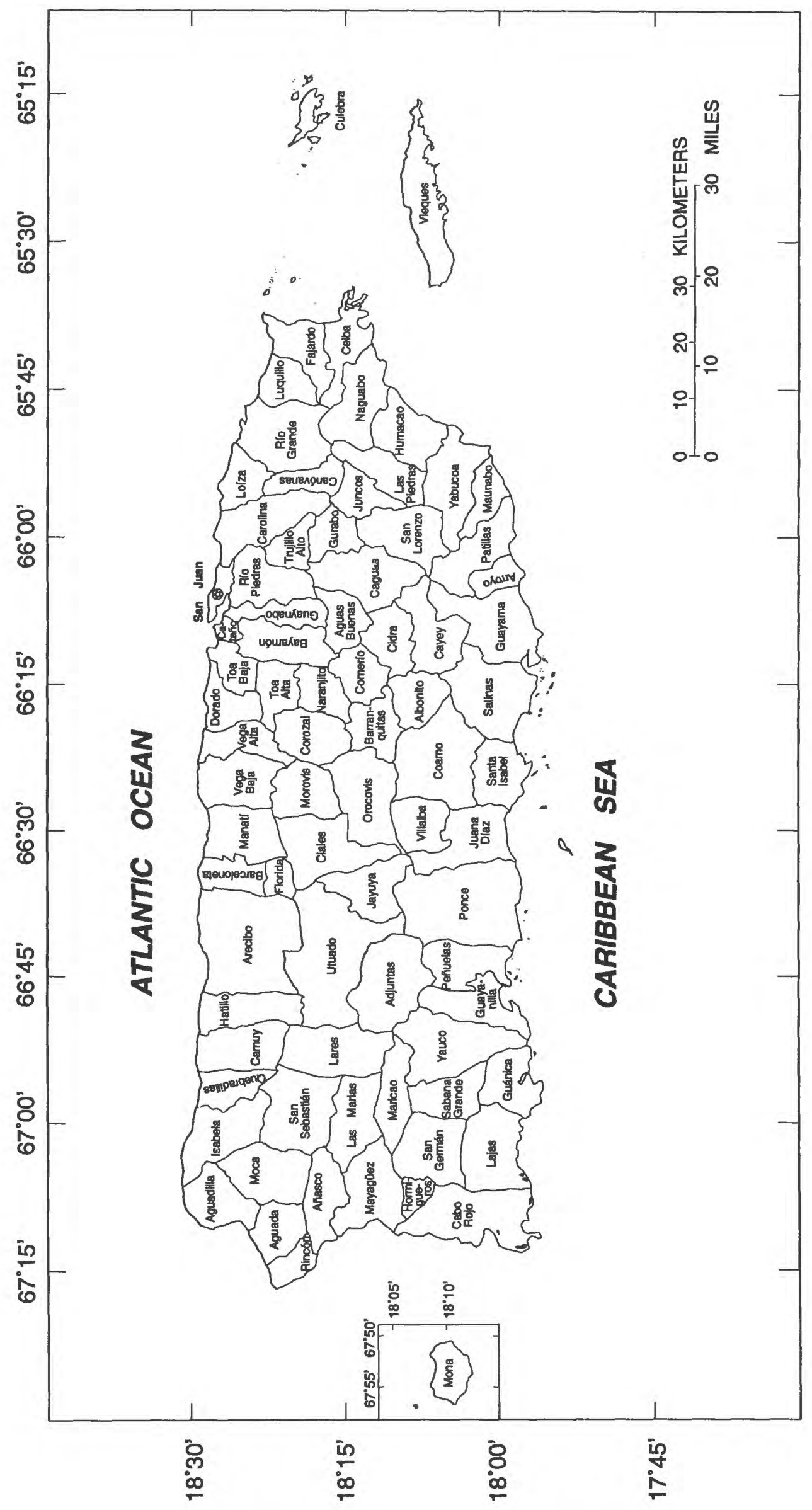

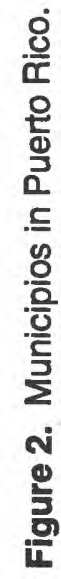




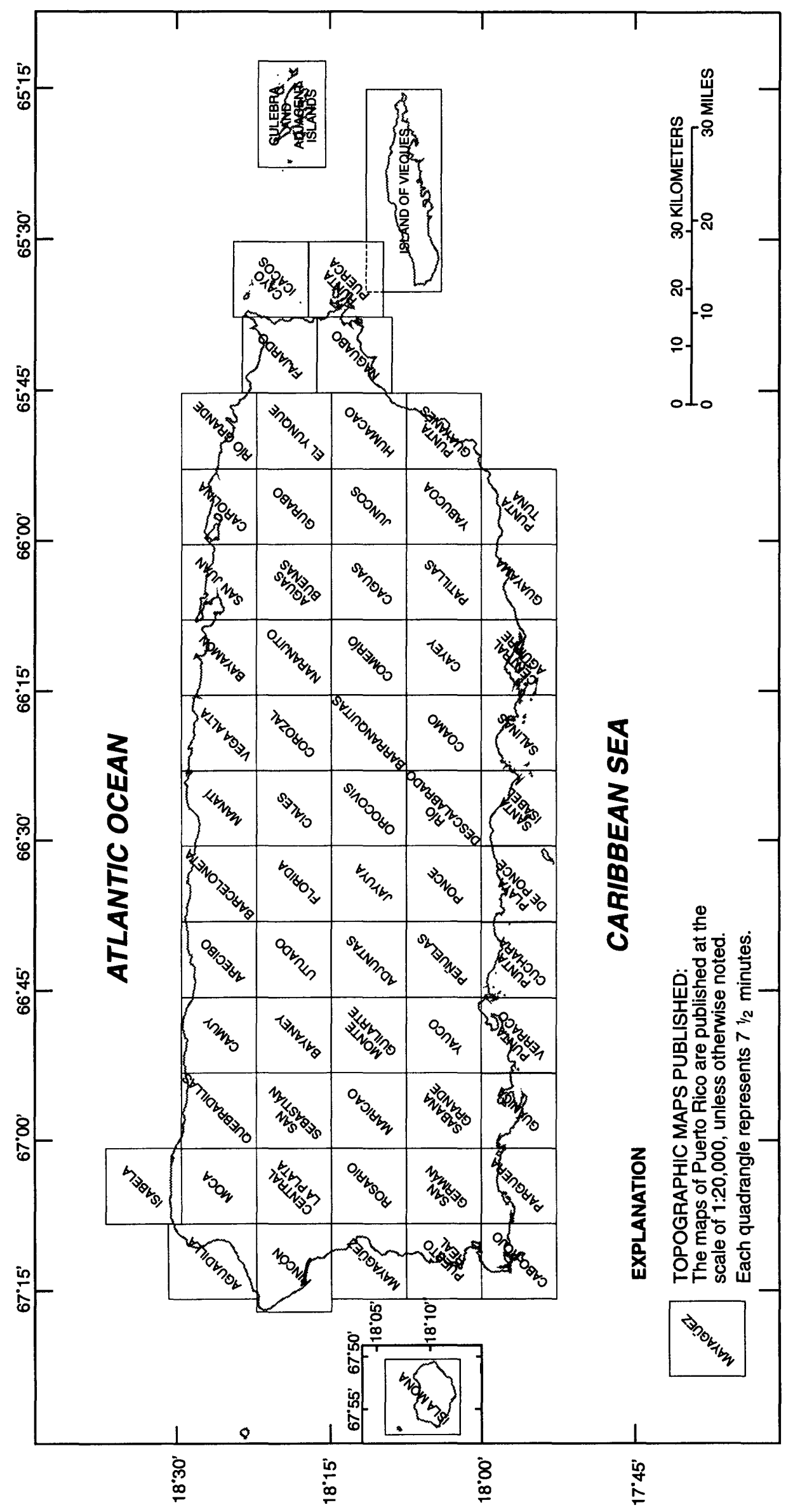

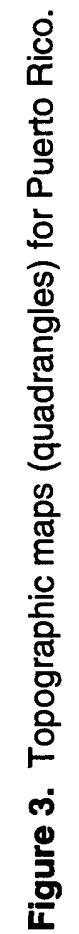




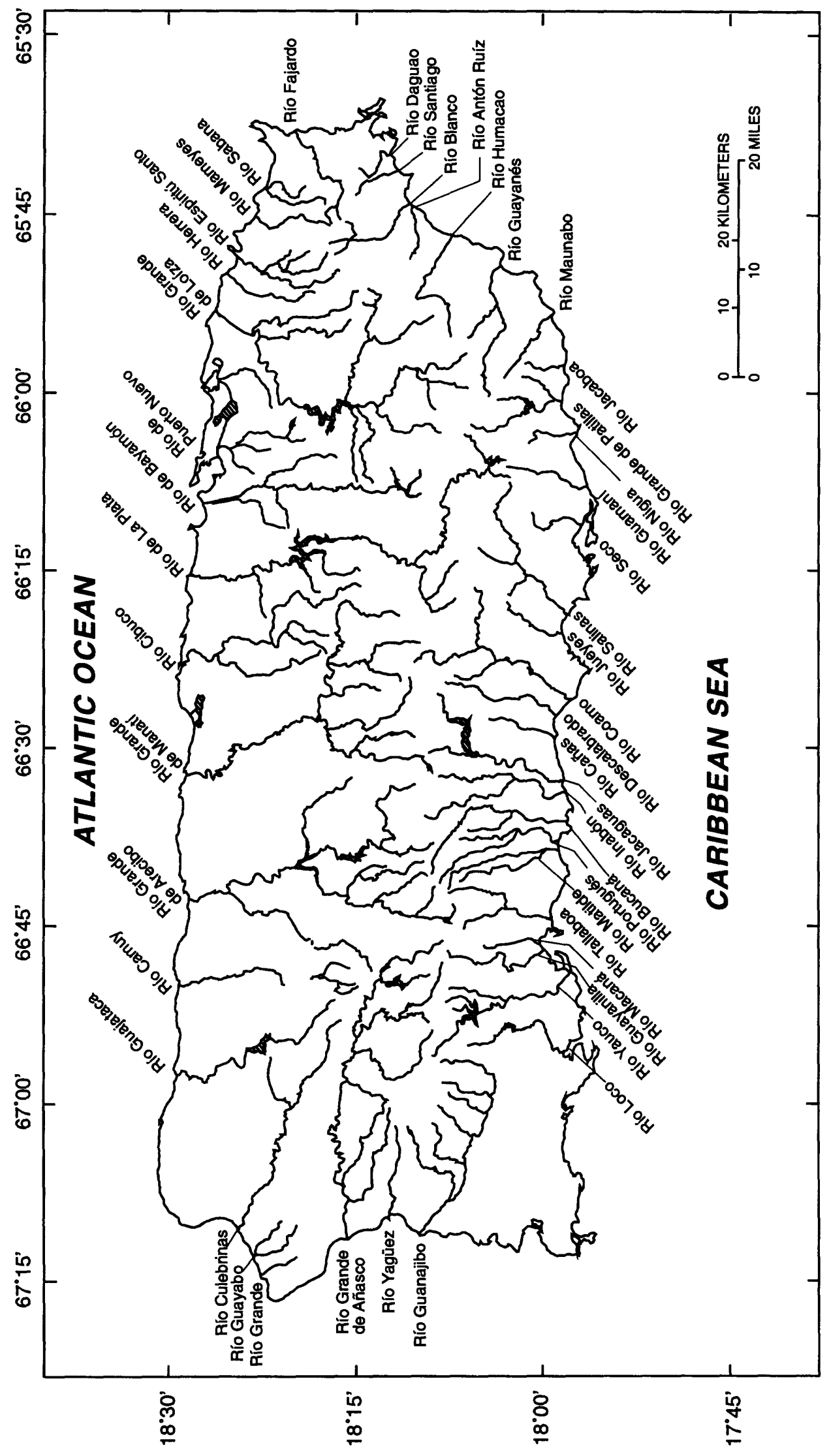

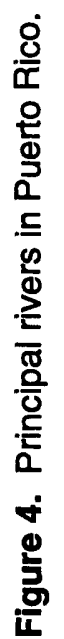



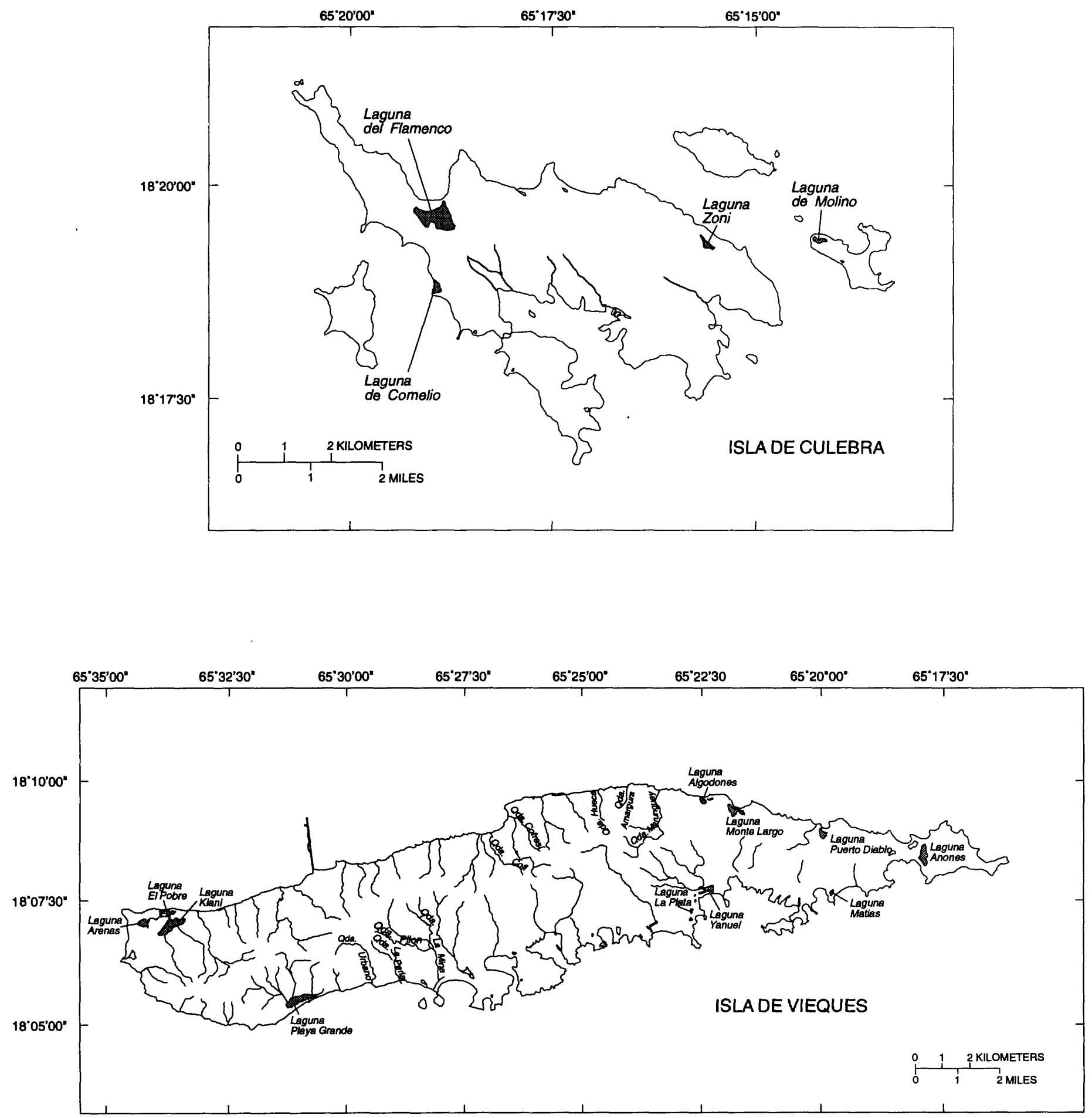

Figure 5. Principal streams in Culebra and Vieques, Puerto Rico. 


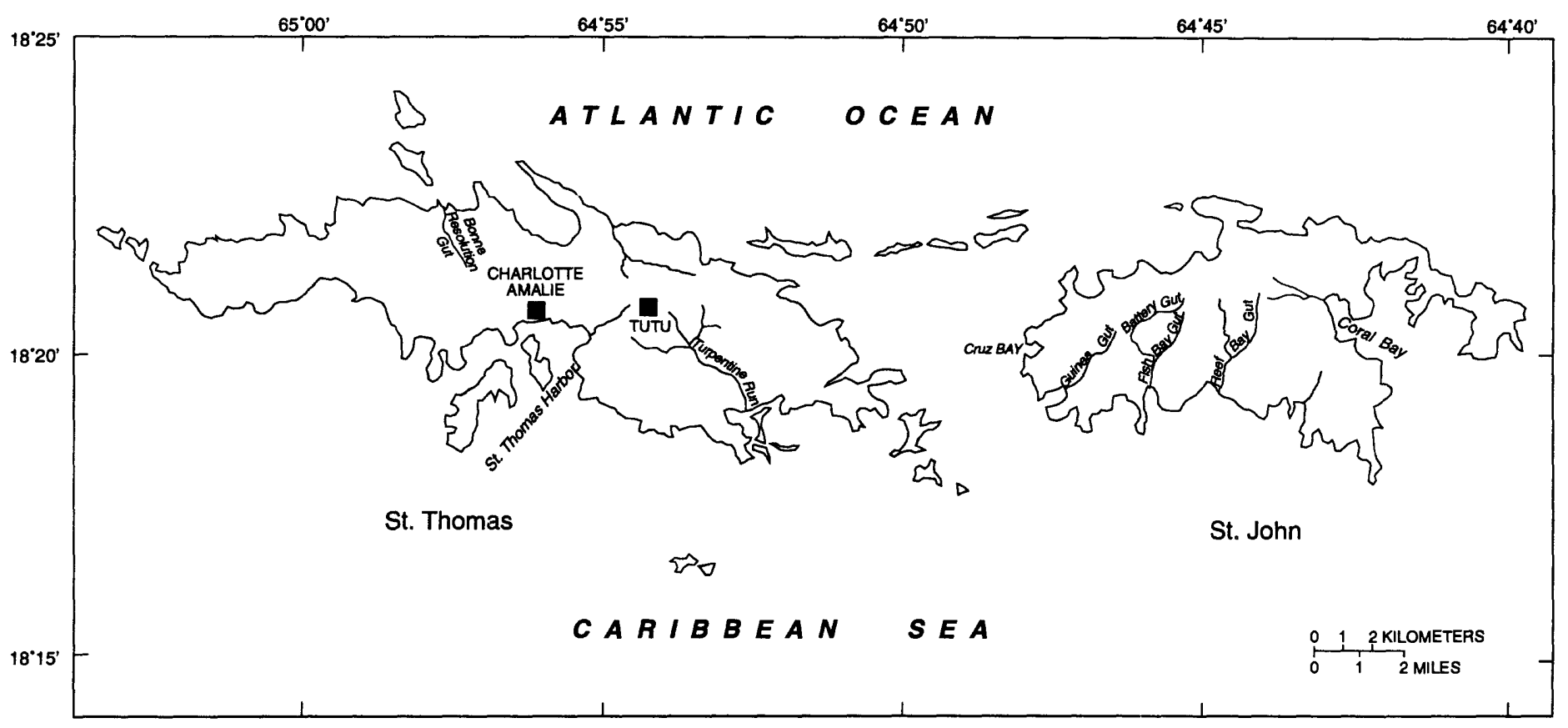

Figure 6. Principal drainages in St. Thomas and St. John, U.S. Virgin Islands.

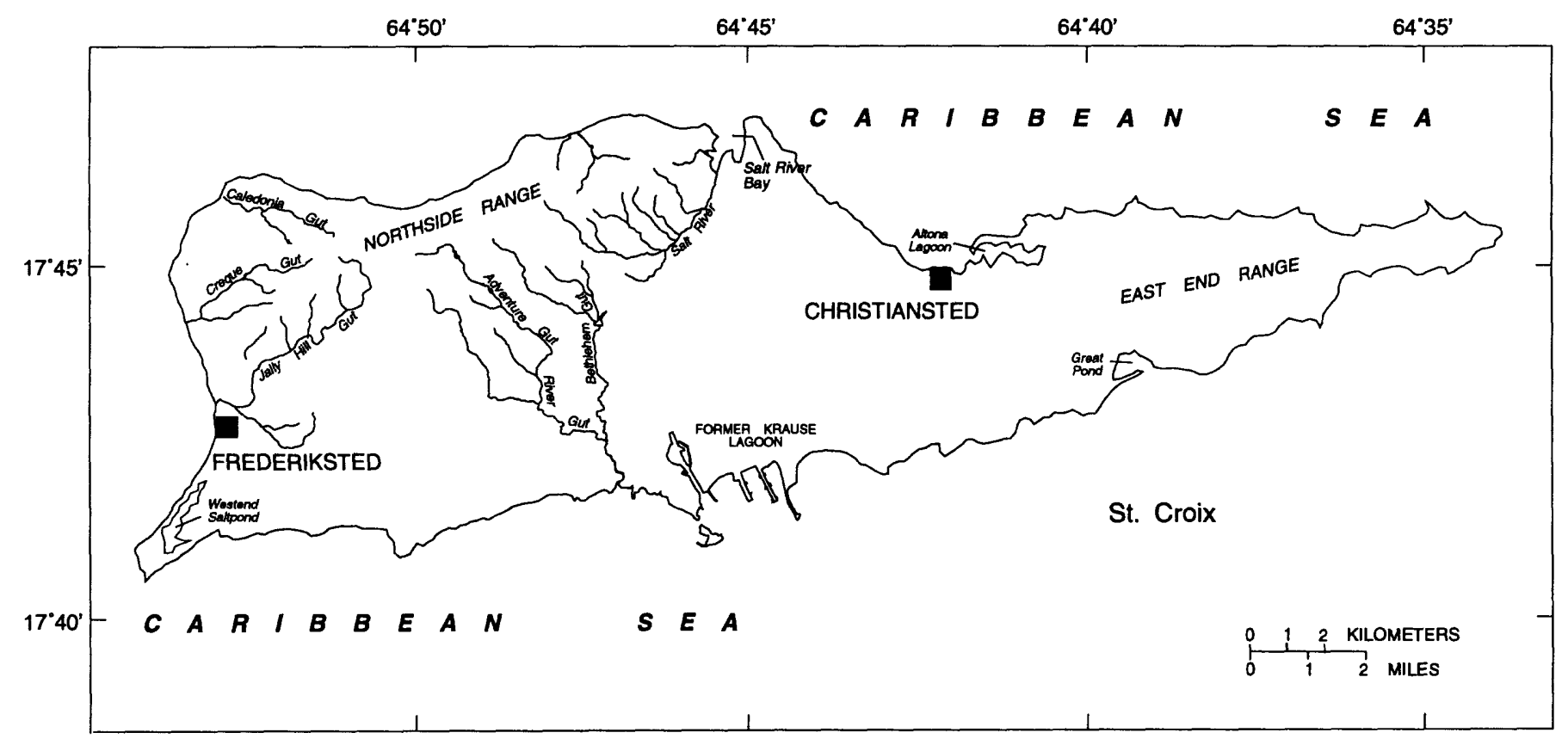

Figure 7. Principal drainages in St. Croix, U.S. Virgin Islands. 


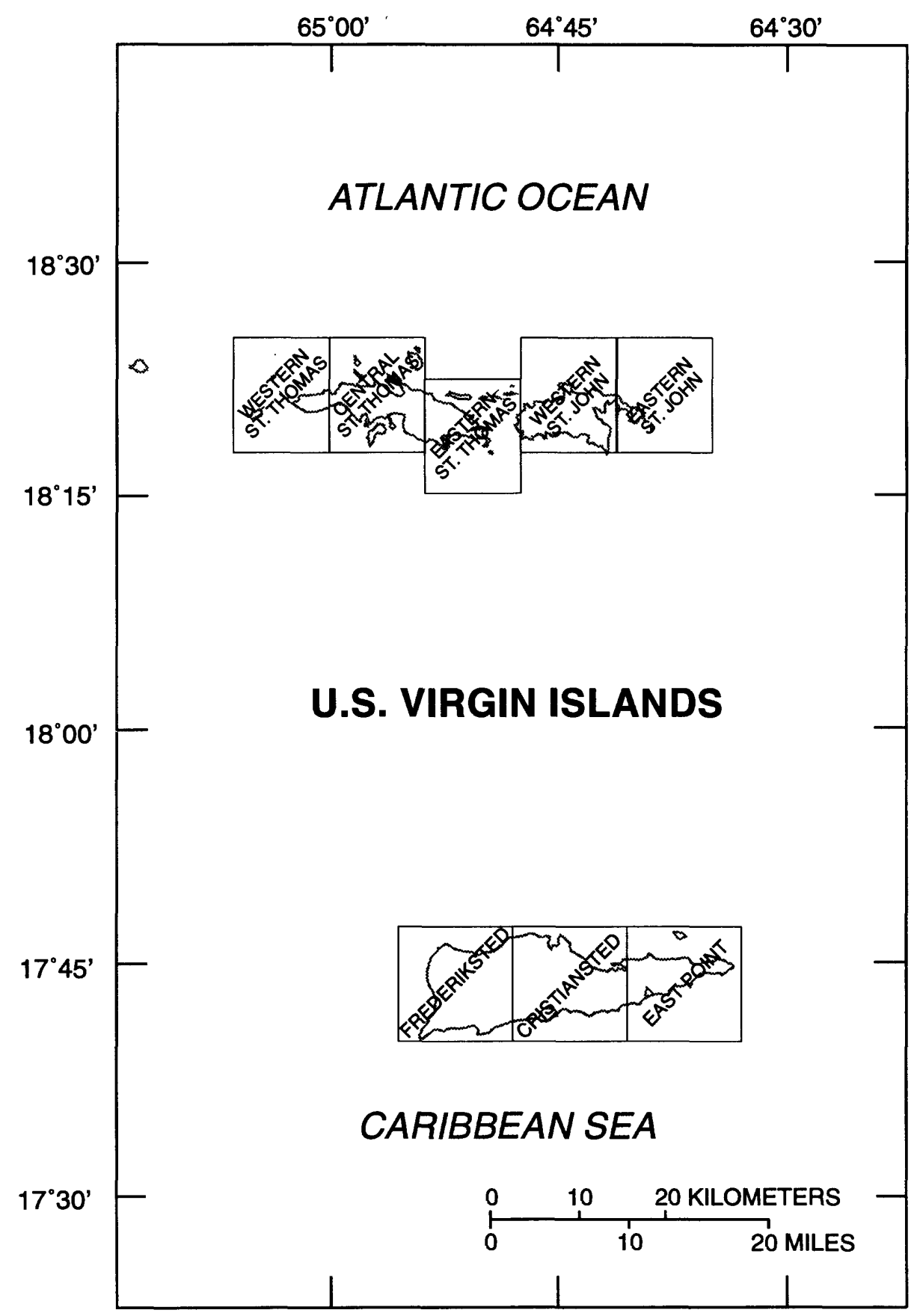

\section{EXPLANATION}

TOPOGRAPHIC MAPS PUBLISHED:

The maps of the U.S. Virgin Islands are published at the scale of $1: 24,000$, unless otherwise noted.

Figure 8. Topographic maps (quadrangles) for the U.S. Virgin Islands. 
(BLANK)

14

Publications of the U.S. Geological Survey, Water Resources Division, for Puerto Rico and the U.S. Virgin Islands, 1899-1992 


\section{LIST OF PUBLICATIONS BY AUTHOR}

The list of publications by author includes all the publications listed in the other four categories of this report. The publications are listed alphabetically by senior author. Non-Geological Survey personnel who share authorship in articles with U.S. Geological Survey personnel are indicated by an asterisk $\left(^{*}\right)$ immediately following the name. 


\section{LIST OF PUBLICATIONS BY AUTHOR}

Adolphson, D.G., Seijo, M.A., and Robison, T.M., 1977, Water resources of the Maunabo Valley, Puerto Rico: U.S. Geological Survey Water-Resources Investigations Report 115-76, 38 p.

Anders, R.B., 1968, Reconnaissance of the water resources of the Central Guanajibo Valley, Cabo Rojo, Puerto Rico: U.S. Geological Survey Open-File Report, 15 p.

Anders, R.B., 1971, Electric analog model study of water in the Yabucoa Valley, Puerto Rico (Phase-1, Collecting preliminary data and assembling available data): U.S. Geological Survey Open-File Report 71-5, 47 p.

Anderson, H.R., 1976, Ground water in the San Juan Metropolitan area, Puerto Rico: U.S. Geological Survey Water-Resources Investigations Report 75-41, 34 p.

Anderson, H.R., 1977, Ground water in the Lajas Valley, Puerto Rico: U.S. Geological Survey Water-Resources Investigations Report 68-76, 45 p.

Arnow, Ted, 1961, Water bearing properties of the rocks in the Arecibo-Barceloneta area, Puerto Rico: in Short Papers in the Geologic and Hydrologic Sciences, Articles 147-292, Geological Survey Research 1961, U.S. Geological Survey Professional Paper 424-C, Article 221, p. 201-202.

Arnow, Ted, and Bogart, D.B., 1959, Water problems of Puerto Rico and a program of water-resources investigations: Transactions of the Second Caribbean Geological Conference, January 4-9, 1959, Mayagüez, Puerto Rico, p. 120-129.

Arnow, Ted, and Crooks, J.W., 1960, Public water supplies in Puerto Rico: U.S. Geological Survey Water-Resources Bulletin 2, $34 \mathrm{p}$.

Arroyo, I.E., Torres-González, Sigfredo, and Carrasquillo, R.A., 1990, A computer program for GEOphysical log data MANagement and plotting (GEOMAN): in Krishna, J.H., Quiñones-Aponte, Vicente, Gómez-Gómez, Fernando, and Morris, G.L., eds., Tropical Hydrology and Caribbean Water Resources, Proceedings of the International Symposium on Tropical Hydrology, San Juan, Puerto Rico, July 23-27, 1990, AWRA TPS-90-2, p. 395-401.

Attanasi, E.D., Close, E.R., and López, M.A., 1975, Techniques for water demand analysis and forecasting, Puerto Rico, A case study: U.S. Geological Survey Open-File Report 75-94, 76 p.

Barnes, H.H., Jr., and Bogart, D.B., 1961, Floods of September 6, 1960, in eastern Puerto Rico: U.S. Geological Survey Circular $451,13 \mathrm{p}$.

Bennett, G.D., 1972, Ground water along Río Bucaná at Ponce, Puerto Rico - And the effects of a proposed floodway on groundwater quality: U.S. Geological Survey Water-Resources Bulletin 11, 29 p.

Bennett, G.D., 1976, Electrical analog simulation of the aquifers along the south coast of Puerto Rico: U.S. Geological Survey Open-File Report 74-4, 101 p.

Bennett, G.D., and Giusti, E.V., 1971, Coastal ground-water flow near Ponce, Puerto Rico: in Geological Survey Research 1971, Chap. D, U.S. Geological Survey Professional Paper 750-D, p. 206-211.

Bennett, G.D., and Giusti, E.V., 1972, Ground water in the Tortuguero area, Puerto Rico - As related to proposed harbor construction: U.S. Geological Survey Water-Resources Bulletin 10, 25 p.

Bogart, D.B., Arnow, Ted, and Crooks, J.W., 1960, Water problems of Puerto Rico and a program of water-resources investigations: U.S. Geological Survey Water-Resources Bulletin 1, 40 p.

Bogart, D.B., Arnow, Ted, and Crooks, J.W., 1964, Water resources of Puerto Rico - A progress report: U.S. Geological Survey Water-Resources Bulletin 4, $120 \mathrm{p}$.

Briggs, R.P., and Akers, J.P., 1965, Hydrogeologic map of Puerto Rico and adjacent islands: U.S. Geological Survey Hydrologic Investigations Atlas HA-197, 1 sheet.

Cederstrom, D.J., 1950, Geology and ground-water resources of St. Croix, Virgin Islands: U.S. Geological Survey Water-Supply Paper 1067, 117 p., 1 pl. 


\section{LIST OF PUBLICATIONS BY AUTHOR--Continued}

Cobb, E.D., 1977, Activities of the Water Resources Division of the U.S. Geological Survey in the Caribbean area in 1976: U.S. Geological Survey Open-File Report 77-674, 32 p.

Cobb, E.D., 1978, Estimates of 7-day, 10-year minimum flows at selected stream sites in Puerto Rico: U.S. Geological Survey Open-File Report 78-583, 19 p.

Collar, P.D., 1991, Fluvial metal transport during a storm event, Río Grande de Loíza basin, Puerto Rico [Abstract]: The Geological Society of America, Abstracts with Programs, v. 23, no. 5, p. 203.

Collar, P.D., and Guzmán-Ríos, Senén, 1991, Sedimentation rates and capacity restoration options, Lago Loíza, Puerto Rico: in Drs. Shou-Shan Fan and Yung-Huang Kuo, eds., Proceedings of the Fifth Federal Interagency Sedimentation Conference, Las Vegas, Nevada, March 18-21, 1991, v. 2, p. 15-17 to 15-25.

Collar, P.D., Troester, J.W., Deike, R.G., and Robinson, P.D.*, 1990, Iron and manganese in alluvial ground water, Yabucoa, Puerto Rico: Proceedings of the Interamerican Association of Sanitary and Environmental Engineers Annual Meeting, v. 3, p. 708-732.

Colón-Dieppa, Eloy, 1986, Puerto Rico surface-water resources - National Water Summary 1985: U.S. Geological Survey WaterSupply Paper 2300, p. 399-406.

Colón-Dieppa, Eloy, and González, J.R., 1981, Ground-water levels in alluvium on the south coast of Puerto Rico, February 1979: U.S. Geological Survey Open-File Report 81-641, 21 p.

Colón-Dieppa, Eloy, and González, Ralph, 1978, Cross section data for selected Puerto Rico streams: U.S. Geological Survey Open-File Report 78-882, 153 p.

Colón-Dieppa, Eloy, and Mansue, L.J., 1976, Water resources of the proposed copper mining area, Puerto Rico, 1958-74 (2 Parts): U.S. Geological Survey Open-File Report 76-1 and 76-2, 414 p.

Colón-Dieppa, Eloy, and Quiñones-Aponte, Vicente, 1985, Estimates of 7-day, 10-year low flow at ungaged streams in Puerto Rico: U.S. Geological Survey Water-Resources Investigations Report 84-4089, 2 sheets.

Colón-Dieppa, Eloy, and Quiñones-Márquez, Ferdinand, 1985, A reconnaissance of the water resources of the Central Río Guanajibo Valley, Puerto Rico: U.S. Geological Survey Water-Resources Investigations Report 82-4050, 47 p.

Colón-Dieppa, Eloy, and Torres-Sierra, Heriberto, 1991, Puerto Rico floods and droughts - National Water Summary 1988-89: U.S. Geological Survey Water-Supply Paper 2375, p. 475-482.

Colón-Dieppa, Eloy, Díaz, P.L., and García, René, 1987, Water resources data Puerto Rico and the U.S. Virgin Islands, Water Year 1985: U.S. Geological Survey Water-Data Report PR-85-1, 400 p.

Colón-Dieppa, Eloy, Torres-Sierra, Heriberto, and Ortíz, Jorge, 1991, U.S. Virgin Islands floods and droughts - National Water Summary 1988-89: U.S. Geological Survey Water-Supply Paper 2375, p. 521-526.

Colón-Ramos, H.M., 1983, Ground-water records for St. Croix, U.S. Virgin Islands, 1969-1973: U.S. Geological Survey OpenFile Data Report 83-546, 28 p.

Colón-Ramos, Héctor, and Colón-Dieppa, Eloy, 1981, Ground-water levels and chloride concentrations in alluvial aquifers on the south coast of Puerto Rico, February 1980: U.S. Geological Survey Open-File Report 81-626, 20 p.

Conde-Costas, Carlos, and Troester, J.W., 1988, The effects of bat guano on carbonate chemistry in Cueva El Convento, Guayanilla, Puerto Rico [Abstract]: National Speleological Society, Forty-Fifth Annual Convention Program, Hot Spring, South Dakota, June 27 to July 1, 1988, p. 34.

Cosner, O.J., 1972, Water in St. John, U.S. Virgin Islands: U.S. Geological Survey Open-File Report 72-78, 46 p.

Crooks, J.W., Grossman, I.G., and Bogart, D.B., 1968, Water resources of the Guayanilla-Yauco area, Puerto Rico: U.S. Geological Survey Water-Resources Bulletin 5, 55 p., 7 pls.

Curtis, R.E., Jr., 1984, Floods of April 18, 1983 on St. Thomas and St. John, U.S. Virgin Islands: U.S. Geological Survey WaterResources Investigations Report 84-4184, 1 sheet. 


\section{LIST OF PUBLICATIONS BY AUTHOR--Continued}

Curtis, R.E., Jr., 1985, Floods of April 18, 1983 on St. Thomas and St. John, U.S. Virgin Islands: Proceedings of the Tropical Hydrology and Second Caribbean Islands Water-Resources Congress, May 5-8, 1985, American Water Resources Association, Technical Publication Series TPS-85-1, p. 90-95.

Curtis, R.E., Jr., Guzmán-Ríos, Senén, and Díaz, P.L., 1984, Water resources data Puerto Rico and the U.S. Virgin Islands, Water Year 1983: U.S. Geological Survey Water-Data Report PR-83-1, 302 p.

Curtis, R.E., Jr., Guzmán-Ríos, Senén, and Díaz, P.L., 1985, Water resources data Puerto Rico and the U.S. Virgin Islands, Water Year 1984: U.S. Geological Survey Water-Data Report PR-84-1, 374 p.

Curtis, R.E., Jr., McKinley P.W., and Colón-Ramos, H.M., 1983, Water resources data Puerto Rico, Water Years 1981-82: U.S. Geological Survey Water-Data Report PR-81-82-1, 414 p.

Curtis, R.E., Jr., Aquino, Zaida, Díaz, P.L., and García, René, 1988, Water resources data Puerto Rico and the U.S. Virgin Islands, Water Year 1986: U.S. Geological Survey Water-Data Report PR-86-1, 362 p.

Curtis, R.E., Jr., Aquino, Zaida, Díaz, P.L., and Vachier, Ricardo, 1989, Water resources data Puerto Rico and the U.S. Virgin Islands, Water Year 1987: U.S. Geological Survey Water-Data Report PR-87-1, 356 p.

Curtis, R.E., Jr., Aquino, Zaida, Díaz, P.L., and Vachier, Ricardo, 1989, Water resources data Puerto Rico and the U.S. Virgin Islands, Water Year 1988: U.S. Geological Survey Water-Data Report PR-88-1, 460 p.

Curtis, R.E., Jr., Aquino, Zaida, Díaz, P.L., and Vachier, Ricardo, 1990, Water resources data Puerto Rico and the U.S. Virgin Islands, Water Year 1989: U.S. Geological Survey Water-Data Report PR-89-1, 419 p.

Curtis, R.E., Jr., Aquino, Zaida, Díaz, P.L., and Vachier, Ricardo, 1991, Water resources data Puerto Rico and the U.S. Virgin Islands, Water Year 1990: U.S. Geological Survey Water-Data Report PR-90-1, 514 p.

Dacosta, Rafael, and Gómez-Gómez, Fernando, 1987, Potentiometric surface of the alluvial aquifer and hydrologic conditions in the Guayama quadrangle, Puerto Rico, March 1986: U.S. Geological Survey Water-Resources Investigations Report 87-4162, 1 sheet.

Díaz, J.R., 1971, Electric analog model study of water in the Guayama area, Puerto Rico (Phase-1, Assembling data for the analog model): U.S. Geological Survey Open-File Report 71-86, 68 p.

Díaz, J.R., 1973, Chemical quality of water in Caño Tiburones, Puerto Rico: A reconnaissance study carried out in 1967: U.S. Geological Survey Open-File Report Map Series no. 2, 2 pls.

Díaz, J.R., 1974, Coastal salinity reconnaissance and monitoring system--south coast of Puerto Rico: U.S. Geological Survey Open-File Report 74-1, 28 p.

Díaz, J.R., 1977, Ground-water levels in alluvium on the south coast of Puerto Rico, February 1977: U.S. Geological Survey OpenFile Report 77-696, 6 p.

Díaz, J.R., 1977, Ground-water levels on the south coast of Puerto Rico, February 1974 to February 1975: U.S. Geological Survey Open-File Report 76-625, 30 p.

Díaz, J.R., 1979, Ground-water levels in alluvium on the south coast of Puerto Rico, February 1978: U.S. Geological Survey OpenFile Report 79-1272, 18 p.

Díaz, J.R., 1979, Seawater intrusion, south coast of Puerto Rico, 1966-77: U.S. Geological Survey Open-File Report 79-1334, 20 p.

Díaz, J.R., and Jordan, D.G., 1987, Water resources of the Río Grande de Añasco - lower Valley, Puerto Rico: U.S. Geological Survey Water-Resources Investigations Report 85-4237, 48 p.

Durfor, C.N., and Becker, Edith, 1964, Chemical quality of public water supplies of the United States and Puerto Rico, 1962: U.S. Geological Survey Hydrologic Investigations Atlas HA-200, 1 sheet.

Durum, W.H., Hem, J.D., and Heidel, S.G., 1971, Reconnaissance of selected minor elements in surface waters of the United States, October 1970: U.S. Geological Survey Circular 643, 49 p. 


\section{LIST OF PUBLICATIONS BY AUTHOR--Continued}

Ellins, K.K., Román-Más, Angel, and Lee, R.N., 1986, Estimating ground water influx to a portion of the Río Grande de Manatí River basin in Puerto Rico through the measurement of ${ }^{222} \mathrm{Rn}$ : in Quiñones, Ferdinand, Sánchez, A.V., and Smith, H.H., eds., Proceedings of the Third Caribbean Islands Water-Resources Congress, U.S. Virgin Islands, July 22-25, 1986, Puerto Rico Water Resources Association, p. 27.

Ellis, S.R., 1976, History of dredging and filling of lagoons in the San Juan area, Puerto Rico: U.S. Geological Survey WaterResources Investigations Report 76-38, 25 p., 4 pls.

Ellis, S.R., and Gómez-Gómez, Fernando, 1975, Water-quality and hydraulic data, San Juan lagoon system, Puerto Rico: U.S. Geological Survey Open-File Report 75-2, 142 p.

Ellis, S.R., and Gómez-Gómez, Fernando, 1976, Hydrologic characteristics of lagoons at San Juan, Puerto Rico, during a January 1974 tidal cycle: U.S. Geological Survey Water-Resources Investigations Report 75-38, 45 p.

Fields, F.K., 1971, Floods in the Añasco area, Puerto Rico: U.S. Geological Survey Hydrologic Investigations Atlas HA-375, 1 sheet.

Fields, F.K., 1971, Floods in the Guayanilla-Yauco area, Puerto Rico: U.S. Geological Survey Hydrologic Investigations Atlas HA-414, 1 sheet.

Fields, F.K., 1971, Floods in the Yabucoa area, Puerto Rico: U.S. Geological Survey Hydrologic Investigations Atlas HA-382, 1 sheet.

Fields, F.K., 1972, Floods at Caguas, Gurabo, Juncos, and San Lorenzo, Puerto Rico: U.S. Geological Survey Hydrologic Investigations Atlas HA-438, 1 sheet.

Fields, F.K., and Jordan, D.G., 1972, Storm-wave swash along the north coast of Puerto Rico: U.S. Geological Survey Hydrologic Investigations Atlas HA-430, 2 sheets.

Figueroa-Alamo, Carlos, 1991, Sedimentation survey of Lago Toa Vaca, Puerto Rico, July 1985: U.S. Geological Survey OpenFile Report 90-199, 9 p.

García, René, and Canoy, Michael, 1984, Reconnaissance of ground-water quality in the Virgin Islands, July 1984: U.S. Geological Survey Open-File Data Report 84-807, 1 sheet.

Gellis, Allen, 1990, Sediment loads in selected streams in Puerto Rico during the passage of Hurricane Hugo [Abstract]: The Geological Society of America, Abstracts with Programs, v. 22, no. 7, p. A331.

Gellis, Allen, 1991, Construction effects on sediment for two basins in Puerto Rico: in Drs. Shou-Shan Fan and Yung-Huang Kuo, eds., Proceedings of the Fifth Federal Interagency Sedimentation Conference, Las Vegas, Nevada, March 18-21, 1991, v. 1, p. 4-72 to 4-78.

Giusti, E.V., 1968, Water resources of the Juana Díaz area, Puerto Rico - A preliminary appraisal, 1966: U.S. Geological Survey Water- Resources Bulletin 8, 43 p.

Giusti, E.V., 1971, Regional specific yield of the Coamo Fan, Puerto Rico, computed by the water budget method: in Geological Survey Research 1971, Chap. B, U.S. Geological Survey Professional Paper 750-B, p. 248-251.

Giusti, E.V., 1971, Water resources of the Coamo area, Puerto Rico: U.S. Geological Survey Water-Resources Bulletin 9, 31 p.

Giusti, E.V., 1978, Hydrogeology of the karst of Puerto Rico: U.S. Geological Survey Professional Paper 1012, 68 p., 2 pls.

Giusti, E.V., and Bennett, G.D., 1976, Water resources of the north coast limestone area, Puerto Rico: U.S. Geological Survey Water-Resources Investigations Report 75-42, $42 \mathrm{p}$

Giusti, E.V., and López, M.A., 1967, Climate and streamflow of Puerto Rico: Caribbean Journal of Science, September December, 1967, v. 7, no. 3-4, p. 87-93.

Gómez-Gómez, Fernando, 1979, Reconnaissance of six solid-waste disposal sites in Puerto Rico and effects on water quality: U.S. Geological Survey Open-File Report 79-1338, 73 p. 


\section{LIST OF PUBLICATIONS BY AUTHOR--Continued}

Gómez-Gómez, Fernando, 1984, Water resources of the lower Río Grande de Manatí Valley: U.S. Geological Survey WaterResources Investigations Report 83-4199, 42 p.

Gómez-Gómez, Fernando, 1986, Caribbean Islands Regional Aquifer-System Study - Phase 1, Regional Aquifer-System Study projects started in 1984: in Ren Jen Sun, ed., Summary of Projects 1978-84: U.S. Geological Survey Circular 1002, p. 234-241.

Gómez-Gómez, Fernando, 1987, Planning report for the Caribbean Islands Regional Aquifer-System Analysis project: U.S. Geological Survey Water-Resources Investigations Report 86-4074, 50 p., 3 pls.

Gómez-Gómez, Fernando, 1990, Hydrochemistry of the South Coastal Plain Aquifer System of Puerto Rico and its relation to surface-water recharge: in Gómez-Gómez, Fernando, Quiñones-Aponte, Vicente, and Johnson, A.I., eds., Aquifers of the Caribbean Islands, Proceedings of the International Symposium on Tropical Hydrology, San Juan, Puerto Rico, July 23-27, 1990, AWRA Monograph Series no. 15, p. 57-75.

Gómez-Gómez, Fernando, and Guzmán-Ríos, Senén, 1982, Reconnaissance of ground-water quality throughout Puerto Rico, September-October 1981: U.S. Geological Survey Open-File Report 82-332, 1 sheet.

Gómez-Gómez, Fernando, and Heisel, J.E., 1980, Summary appraisals of the Nation's ground-water resources - Caribbean Region: U.S. Geological Survey Professional Paper 813-U, 32 p., 2 pls.

Gómez-Gómez, Fernando, and Torres-Sierra, Heriberto, 1988, Hydrology and effects of development on the water-table aquifer in the Vega Alta quadrangle, Puerto Rico: U.S. Geological Survey Water-Resources Investigations Report 87-4105, 54 p.

Gómez-Gómez, Fernando, Dacosta, Rafael, and Orona, Miguel, 1983, Estimated water use in Puerto Rico, 1980 -- U.S. Geological Survey water-use information program: U.S. Geological Survey Water Resources Division Miscellaneous Map Series, 1 sheet.

Gómez-Gómez, Fernando, Quiñones, Ferdinand, and Ellis, S.R., 1983, Hydrologic characteristics of lagoons at San Juan, Puerto Rico, during an October 1974 tidal cycle: U.S. Geological Survey Water-Resources Investigations Open-File Report 82-349, 34 p.

Gómez-Gómez, Fernando, Quiñones, Ferdinand, and López, Marisol, 1984, Public water supplies in Puerto Rico, 1983: U.S. Geological Survey Open-File Data Report 84-126, 102 p.

Gómez-Gómez, Fernando, Quiñones-Márquez, Ferdinand, and Zack, A.L., 1984, U.S. Virgin Islands ground-water resources National Water Summary 1984: U.S. Geological Survey Water-Supply Paper 2275, p. 409-413.

Graves, R.P., 1989, Water resources of the Humacao-Naguabo area, eastern Puerto Rico: U.S. Geological Survey Water-Resources Investigations Report 87-4088, 69 p.

Graves, R.P., 1991, Ground-water resources in Lajas Valley, Puerto Rico: U.S. Geological Survey Water-Resources Investigations Report 89-4182, $55 \mathrm{p}$.

Graves, R.P., 1992, Geohydrology of the Aguirre and Pozo Hondo areas, southern Puerto Rico: U.S. Geological Survey WaterResources Investigations Report 91-4124, 43 p.

Graves, R.P., and González, Ralph, 1988, Potentiometric surface of the Turpentine Run basin aquifer in the Tutu area, eastern St. Thomas, U.S. Virgin Islands, September 11, 1987: U.S. Geological Survey Water-Resources Investigations Report 88-4131, 1 sheet.

Grossman, I.G., 1959, Ground-water data from St. Thomas, Virgin Islands: U.S. Geological Survey Open-File Report, 35 p., 5 pls.

Grossman, I.G., 1961, Ground-water conditions in the lower Tallaboa Valley, Puerto Rico: in Short Papers in the Geologic and Hydrologic Sciences, Articles 147-292, U.S. Geological Survey Professional Paper 424-C, Article 222, p. 202-203.

Grossman, I.G., 1962, Chemical quality of ground water in St. Thomas, Virgin Islands: in Short Papers in Geology, Hydrology, and Topography, Articles 1-59, U.S. Geological Survey Professional Paper 450-B, Article 55, p. 131-133.

Grossman, I.G., 1962, Stratigraphy and hydrology of the Juana Díaz Formation in the Yauco area, Puerto Rico: in Short Papers in Geology, Hydrology, and Topography, Articles 120-179, U.S. Geological Survey Professional Paper 450-D, Article 137, p. 62-63. 


\section{LIST OF PUBLICATIONS BY AUTHOR--Continued}

Grossman, I.G., 1963, Geology of the Guánica-Guayanilla bay area, southwestern Puerto Rico: in Short Papers in Geology and Hydrology, Articles 1-59, U.S. Geological Survey Professional Paper 475-B, Article 29, p. 114-116.

Grossman, I.G., 1966, Fluctuations of ground-water levels in Puerto Rico resulting from earthquakes (1959-1961) [Abstract]: Transactions of the Third Caribbean Geological Conference, Kingston, Jamaica, April 1962, p. 104-105.

Grossman, I.G., Bogart, D.B., Crooks, J.W., and Díaz, J.R., 1972, Water resources of the Tallaboa Valley, Puerto Rico: U.S. Geological Survey Water-Resources Bulletin 7, 115 p.

Guariguata, M.R., and Larsen, M.C., 1990, Preliminary map showing locations of landslides in El Yunque quadrangle, Puerto Rico: U.S. Geological Survey Open-File Report 89-257, 1 sheet.

Guzmán-Ríos, Senén, 1983, Reconnaissance of the principal springs of Puerto Rico, 1982-83: U.S. Geological Survey Open-File Data Report 83-683, 1 sheet.

Guzmán-Ríos, Senén, 1988, Hydrology and water quality of the principal springs in Puerto Rico: U.S. Geological Survey WaterResources Investigations Report 85-4269, $30 \mathrm{p}$.

Guzmán-Ríos, Senén, 1989, Suspended-sediment data in the upper Río Grande de Loíza basin, Puerto Rico: U.S. Geological Survey Open-File Data Report 88-324, 42 p.

Guzmán-Ríos, Senén, and Quiñones-Márquez, Ferdinand, 1984, Ground-water quality at selected sites throughout Puerto Rico, September 1982 - July 1983: U.S. Geological Survey Open-File Data Report 84-058, 1 sheet.

Guzmán-Ríos, Senén, and Quiñones-Márquez, Ferdinand, 1985, Reconnaissance of trace organic compounds in ground water throughout Puerto Rico, October 1983: U.S. Geological Survey Open-File Data Report 84-810, 1 sheet.

Haire, W.J., 1971, Flooding along the Río Piedras in the San Juan area, Puerto Rico: U.S. Geological Survey Hydrologic Investigations Map Series no. 1, 2 sheets.

Haire, W.J., 1971, Floods in Salinas area, Puerto Rico: U.S. Geological Survey Hydrologic Investigations Atlas HA-447, 1 sheet.

Haire, W.J., 1971, Floods in the Guayama area, Puerto Rico: U.S. Geological Survey Hydrologic Investigations Atlas HA-446, 1 sheet.

Haire, W.J., 1971, Floods in the Patillas-Maunabo area, Puerto Rico: U.S. Geological Survey Hydrologic Investigations Atlas HA-445, 1 sheet.

Haire, W.J., 1971, Floods in the Santa Isabel area, Puerto Rico: U.S. Geological Survey Hydrologic Investigations Atlas HA-448, 1 sheet.

Haire, W.J., 1972, Floods in the Río Guanajibo Valley, southwestern Puerto Rico: U.S. Geological Survey Hydrologic Investigations Atlas HA-456, 1 sheet.

Haire, W.J., 1972, Flood of October 5-10, 1970 in Puerto Rico: U.S. Geological Survey Water-Resources Bulletin 12, 38 p.

Haire, W.J., 1975, Floods in the Carolina-Río Grande area, northeastern Puerto Rico: U.S. Geological Survey Hydrologic Investigations Atlas HA-533, 1 sheet.

Haire, W.J., 1975, Floods in the Fajardo-Luquillo area, northeastern Puerto Rico: U.S. Geological Survey Hydrologic Investigations Atlas HA-545, 1 sheet.

Haire, W.J., 1978, Floods in the Naguabo area, eastern Puerto Rico: U.S. Geological Survey Hydrologic Investigations Atlas HA-584, 1 sheet.

Haire, W.J., and Johnson, K.G., 1973, Floods in and near the Charlotte Amalie area, St. Thomas, U.S. Virgin Islands: U.S. Geological Survey Hydrologic Investigations Map Series no. 3, 4 sheets.

Haire, W.J., and Johnson, K.G., 1977, Floods of November 12, 1974, in the Charlotte Amalie area, St. Thomas, U.S. Virgin Islands: U.S. Geological Survey Water-Resources Investigations Report 76-91, 3 sheets. 


\section{LIST OF PUBLICATIONS BY AUTHOR--Continued}

Haire, W.J., and Johnson, K.G., 1978, Floods of November 11-13, 1974, in St. Croix, U.S. Virgin Islands: U.S. Geological Survey Water-Resources Investigations Report 77-136, 11 sheets.

Harris, K.F., 1962, Inventory of published and unpublished sediment-load data, United States and Puerto Rico, 1950-60: U.S. Geological Survey Water-Supply Paper 1547, 117 p.

Heisel, J.E., and González, J.R., 1976, Ground-water levels on the south coast of Puerto Rico, February 1976: U.S. Geological Survey Open-File Report 76-705, 13 p.

Heisel, J.E., and González, J.R., 1979, Water budget and hydraulic aspects of artificial recharge, south coast of Puerto Rico: U.S. Geological Survey Water-Resources Investigations Report 78-58, 102 p.

Heisel, J.E., González, J.R., and Cruz, Carlos, 1983, Analog model analysis of the north coast limestone aquifers, Puerto Rico: U.S. Geological Survey Open-File Report 82-52, 49 p.

Hendrickson, G.E., 1962, Development of the ground-water resources of St. Croix, Virgin Islands: U.S. Geological Survey OpenFile Report, 84 p.

Hendrickson, G.E., 1963, Ground water for public supply in St. Croix, Virgin Islands: U.S. Geological Survey Water-Supply Paper 1663-D, $27 \mathrm{p}$.

Hickenlooper, I.J., 1967, Floods at Barceloneta and Manatí, Puerto Rico: U.S. Geological Survey Hydrologic Investigations Atlas HA-262, 1 sheet.

Hickenlooper, I.J., 1968, Floods at Arecibo, Puerto Rico: U.S. Geological Survey Hydrologic Investigations Atlas HA-271, 1 sheet.

Hickenlooper, I.J., 1968, Floods in the area of Vega Alta and Vega Baja, Puerto Rico: U.S. Geological Survey Hydrologic Investigations Atlas HA-289, 1 sheet.

Hickenlooper, I.J., 1968, Floods in the Mayagüez area of Puerto Rico: U.S. Geological Survey Hydrologic Investigations Atlas HA-288, 1 sheet.

Hickenlooper, I.J., and López, M.A., 1967, Floods in the Ponce area, Puerto Rico: U.S. Geological Survey Hydrologic Investigations Atlas HA-261, 1 sheet.

Johnson, K.G., 1972, Floods in the Aguadilla-Aguada area, northwestern Puerto Rico: U.S. Geological Survey Hydrologic Investigations Atlas HA-457, 1 sheet.

Johnson, K.G., 1974, Floods in eastern Lajas Valley and the lower Río Loco basin, southwestern Puerto Rico: U.S. Geological Survey Hydrologic Investigations Atlas HA-532, 1 sheet.

Johnson, K.G., 1981, Flood of September 16, 1975, in Tallaboa Valley, Puerto Rico: U.S. Geological Survey Open-File Report $80-1283,5$ sheets.

Johnson, K.G., 1982, Flood of September 16, 1975, in the Guanajibo Valley, Puerto Rico: U.S. Geological Survey Open-File Report 81-805, 1 sheet.

Johnson, K.G., 1982, Flood of September 16, 1975, in the Guayanilla Valley, Puerto Rico: U.S. Geological Survey Open-File Report 80-1282, 1 sheet.

Johnson, K.G., 1982, Flood of September 16, 1975, in the Yauco Valley, Puerto Rico: U.S. Geological Survey Open-File Report 81-331, $13 \mathrm{p}$.

Johnson, K.G., and Carrasquillo, R.A., 1982, Floods of October 9, 1970, and September 16, 1975, at Jayuya, Puerto Rico: U.S. Geological Survey Open-File Report 81-346, 1 sheet.

Johnson, K.G., and González, Ralph, 1982, Flood of September 16, 1975, in the Guánica area, Puerto Rico: U.S. Geological Survey Open-File Report 81-480, 1 sheet.

Johnson, K.G., and Quiñones-Aponte, Vicente, 1982, Flood of September 16, 1975, in the Añasco area, Puerto Rico: U.S. Geological Survey Open-File Report 81-345, 1 sheet. 


\section{LIST OF PUBLICATIONS BY AUTHOR--Continued}

Johnson, K.G., Carrasquillo, R.A., and González, Ralph, 1982, Flood of October 8, 1977, in St. Croix, U.S. Virgin IsIands: U.S. Geological Survey Open-File Report 82-262, 21 p., 3 pls.

Johnson, K.G., Quiñones, Ferdinand, and Alicea, José, 1982, Flood of September 16, 1975, at Utuado, Puerto Rico: U.S. Geological Survey Open-File Report 81-413, 1 sheet.

Johnson, K.G., Quiñones, Ferdinand, and González, Ralph, 1987, Hydraulic analyses of water-surface profiles in the vicinity of the Coamo Dam and Highway 52 bridge, southern Puerto Rico; Flood analyses as related to the flood of October 7, 1985: U.S. Geological Survey Water-Resources Investigations Report 87-4039, 26 p.

Jordan, D.G., 1970, Water and copper-mine tailings in karst terrane of Río Tanamá basin, Puerto Rico: U.S. Geological Survey Open-File Report 71-163, 24 p.

Jordan, D.G., 1972, Land-use effect on the water regimen of the U.S. Virgin Islands: in Geological Survey Research 1972, Chap. D, U.S. Geological Survey Professional Paper 800-D, p. 211-216.

Jordan, D.G., 1975, A survey of the water resources of St. Croix, Virgin Islands: U.S. Geological Survey Open-File Report 73-137, $51 \mathrm{p}$.

Jordan, D.G., and Cosner, O.J., 1973, A survey of the water resources of St. Thomas, Virgin Islands: U.S. Geological Survey Open-File Report 72-201, 55 p.

Jordan, D.G., and Fisher, D.W., 1977, Relation of bulk precipitation and evaporation to water quality and water resources, St. Thomas, Virgin Islands: U.S. Geological Survey Water-Supply Paper 1663-I, 30 p.

Jordan, D.G., and Gilbert, B.K., 1976, Water supply and waste disposal, Culebra, Puerto Rico: U.S. Geological Survey WaterResources Investigations 76-3, $31 \mathrm{p}$.

Kipple, F.P., and others, 1968, Water records of Puerto Rico, 1958-63: U.S. Geological Survey Water-Data Report, 353 p.

Larsen, M.C., 1989, Use of seismic refraction techniques for investigating morphology of recent landslides in a tropical rain forest in Puerto Rico [Abstract]: The Geological Society of America, Abstracts with Programs, v. 21, no. 3, p. 46.

Larsen, M.C., 1990, Landslides and pore pressure responses associated with Hurricane Hugo, September 1989, eastern Puerto Rico [Abstract]: The Geological Society of America, Abstracts with Programs, v. 22, no. 7., p. A331.

Larsen, M.C., 1990, Landslides caused by the intense precipitation of Hurricane Hugo in El Yunque and surrounding areas: Boletín Oficial de la Sociedad de Historia Natural de Puerto Rico, v. 24, no. 12, p. 8.

Larsen, M.C., 1990, Landslides caused by the intense precipitation of Hurricane Hugo, September 1989, eastern Puerto Rico [Abstract]: EOS, Transactions, American Geophysical Union, v. 71, no. 6., p. 257.

Larsen, M.C., 1991, Mass wasting disturbance and denudation in a humid-tropical montane forest, Puerto Rico [Abstract]: The Geological Society of America, Abstracts with Programs, v. 23, no. 5, p. A256.

Larsen, M.C., and Simon, Andrew, 1990, Landslide processes in saprolitic soils of a tropical rain forest, Puerto Rico: in Larue, D.K., and Draper, G., eds., Transactions of the 12th Caribbean Geological Conference, St. Croix, U.S. Virgin Islands, Miami Geological Society, p. 217-222.

Larsen, M.C., and Simon, Andrew, 1992, A rainfall intensity-duration threshold relation for landslide occurrence in the humidtropical environment of Puerto Rico [Abstract]: The Geological Society of America, Abstracts with Programs, v. 24, no. 7, p. A166.

Larsen, M.C., and Torres-Sánchez, A.J., 1990, Rainfall-soil moisture relations in landslide-prone areas of a tropical rain forest, Puerto Rico: in Krishna, J.H., Quiñones-Aponte, Vicente, Gómez-Gómez, Fernando, and Morris, G.L., eds., Tropical Hydrology and Caribbean Water Resources, Proceedings of the International Symposium on Tropical Hydrology, San Juan, Puerto Rico, July 23-27, 1990, AWRA TPS-90-2, p. 121-129.

Larsen, M.C., and Torres-Sánchez, A.J., 1992, Landslides triggered by Hurricane Hugo in eastern Puerto Rico, September 1989: Caribbean Journal of Science, v. 28, no. 3-4, p. 113-125. 


\section{LIST OF PUBLICATIONS BY AUTHOR--Continued}

Lohr, E.W., 1957, Chemical character of public water supplies of the larger cities in Alaska, Hawaii, and Puerto Rico, 1954: U.S. Geological Survey Water-Supply Paper 1460-A, 39 p., 1 pl.

López, M.A., 1962, Floods at Bayamón and Cataño, Puerto Rico: U.S. Geological Survey Hydrologic Investigations Atlas HA-77, 1 sheet.

López, M.A., 1964, Floods at Toa Alta, Toa Baja, and Dorado, Puerto Rico: U.S. Geological Survey Hydrologic Investigations Atlas HA-128, 1 sheet.

López, M.A., 1967, Floods at Humacao, Puerto Rico: U.S. Geological Survey Hydrologic Investigations Atlas HA-265, 1 sheet.

López, M.A., and Fields, F.K., 1970, A proposed streamflow-data program for Puerto Rico: U.S. Geological Survey Open-File Report, 42 p.

López, M.A., Colón-Dieppa, Eloy, and Cobb, E.D., 1979, Floods in Puerto Rico, magnitude and frequency: U.S. Geological Survey Water-Resources Investigations Report 78-141, 68 p.

McClymonds, N.E., 1967, Water resources of the Guánica area, Puerto Rico - A preliminary appraisal, 1963: U.S. Geological Survey Water-Resources Bulletin 6, 43 p.

McClymonds, N.E., 1972, Water resources of the Ponce area, Puerto Rico: U.S. Geological Survey Water-Resources Bulletin 14, $26 \mathrm{p}$.

McClymonds, N.E., and Díaz, J.R., 1972, Water resources of the Jobos area, Puerto Rico - A preliminary appraisal, 1962: U.S. Geological Survey Water-Resources Bulletin 13, 32 p.

McClymonds, N.E., and Ward, P.E., 1966, Hydrologic characteristics of the alluvial fan near Salinas, Puerto Rico: in Geological Survey Research 1966, Chap. C, U.S. Geological Survey Professional Paper 550-C, p. 231-234.

McCoy, J.H., 1978, Summary of the water resources of Puerto Rico: U.S. Geological Survey Open-File Report 78-971, 24 p.

McGuinness, C.L., 1946, Ground-water reconnaissance of Vieques Island, Puerto Rico: U.S. Geological Survey Open-File Report.

McGuinness, C.L., 1946, Records of wells in Puerto Rico: U.S. Geological Survey Open-File Report, 267 p.

McGuinness, C.L., 1948, Ground-water resources of Puerto Rico: U.S. Geological Survey Open-File Report, 277 p.

McGuinness, C.L., 1953, Summary of the water resources of the Virgin Islands: U.S. Geological Survey Open-File Report, 8 p.

McKinley, P.W., 1985, Surface water data network analysis for Puerto Rico: U.S. Geological Survey Water-Resources Investigations Report 83-4055, $14 \mathrm{p}$.

Menoyo, L.E., 1992, Using a microcomputer to create an animated three-dimensional visualization of Bahía de Añasco, Puerto Rico [Abstract]: Joint U.S. Geological Survey/Jet Propulsion Laboratory Scientific Visualization Workshop, Program and Abstracts, Norfolk, Virginia, May 18-19, 1992, p. 22.

Monroe, W.H., 1976, The karst landforms of Puerto Rico: U.S. Geological Survey Professional Paper 899, 69 p., 1 pl.

-. Monroe, W.H., 1979, Map showing landslides and areas of susceptibility to landsliding in Puerto Rico: U.S. Geological Survey Miscellaneous Investigations Map Series, 1 sheet.

Monroe, W.H., 1980, Geology of the middle Tertiary Formations of Puerto Rico: U.S. Geological Survey Professional Paper 953, 93 p., 1 pl.

Monroe, W.H., 1980, Some tropical landforms of Puerto Rico: U.S. Geological Survey Professional Paper 1159, 39 p., 1 pl.

Peck, D.L., Troester, J.W., and Moore, J.E., 1988, Karst hydrogeology in the United States of America: U.S. Geological Survey Open-File Report 88-476, 19 p.

Puig, J.C., and Rodríguez, J.M., 1990, Potentiometric surface of the alluvial aquifer and hydrologic conditions near Gurabo and Juncos, Puerto Rico, March 1988: U.S. Geological Survey Water-Resources Investigations Report 90-4059, 2 sheets. 


\section{LIST OF PUBLICATIONS BY AUTHOR--Continued}

Puig, J.C., and Rodríguez, J.M., 1992, Ground-water resources of the Caguas-Juncos Valley, Puerto Rico: U.S. Geological Survey Water-Resources Investigations Report 91-4079, 48 p.

Puig, J.C., Rodríguez-del-Río, Félix, and Rodríguez, J.M., 1989, Potentiometric surface of the alluvial aquifer and hydrologic conditions near Caguas, Puerto Rico, March 1988: U.S. Geological Survey Water-Resources Investigations Report 89-4075, 1 sheet.

Puig, J.C., Rolón-Collazo, L.I., and Pagán-Trinidad, Ismael*, 1990, Development of an aquifer management model: AQMAN3D: in Krishna, J.H., Quiñones-Aponte, Vicente, Gómez-Gómez, Fernando, and Morris, G.L., eds., Tropical Hydrology and Caribbean Water Resources, Proceedings of the International Symposium on Tropical Hydrology, San Juan, Puerto Rico, July 23-27, 1990, AWRA TPS-90-2, p. 39-48.

Quiñones, Ferdinand, and Alicea, José, 1981, Water resources investigations in Puerto Rico and the U.S. Virgin Islands Programs and activities of the U.S. Geological Survey, Water Resources Division, Caribbean District: U.S. Geological Survey Open-File Report, 69 p.

Quiñones, Ferdinand, and Alicea, José, 1983, Water resources investigations in Puerto Rico and the U.S. Virgin Islands Programs and activities of the U.S. Geological Survey, Water Resources Division, Caribbean District: U.S. Geological Survey Open-File Report, 28 p.

Quiñones, Ferdinand, and Alicea, José, 1984, Water rcsources investigations in Puerto Rico and the U.S. Virgin Islands Programs and activities of the U.S. Geological Survey, Water Resources Division, Caribbean District: U.S. Geological Survey Open-File Report, 41 p.

Quiñones, Ferdinand, and Alicea-Ortíz, José, 1985, Agua subterránea en Puerto Rico: U.S. Geological Survey Open-File Report 85-642,6 p.

Quiñones, Ferdinand, and Johnson, K.G., 1987, The floods of May 17-18, 1985, and October 6-7, 1985, in Puerto Rico: U.S. Geological Survey Open-File Report 87-123, 22 p.

Quiñones, Ferdinand, and López, Marisol, 1984, Publications of the U.S. Geological Survey, Water Resources Division for Puerto Rico and the U.S. Virgin Islands, 1946-1984: U.S. Geological Survey Open-File Data Report 84-229, 32 p.

Quiñones, Ferdinand, and Rivera, Elba, 1985, Publications of the U.S. Geological Survey, Water Resources Division for Puerto Rico and the U.S. Virgin Islands, 1946-1985: U.S. Geological Survey Open-File Data Report 85-414, 21 p.

Quiñones, Ferdinand, Colón-Dieppa, Eloy, and Juarbe, Max*, 1984, Flow duration at streamflow gaging stations in Puerto Rico: U.S. Geological Survey Open-File Data Report 84-127, 93 p.

Quiñones, Ferdinand, Green, Bruce, and Santiago, Luis, 1989, Sedimentation survey of Lago Loíza, Puerto Rico, July 1985: U.S. Geological Survey Water-Resources Investigations Report 87-4019, 17 p.

Quiñones, Ferdinand, Meléndez, Frank, and Bonnet, Carlos, 1989, Sedimentation survey of Lago Dos Bocas, Puerto Rico, June 1985: U.S. Geological Survey Open-File Report 86-241, 14 p.

Quiñones-Aponte, Vicente, 1986, Simulation of ground-water flow in the Río Yauco alluvial valley, Yauco, Puerto Rico: U.S. Geological Survey Water-Resources Investigations Report 85-4179, 32 p.

Quiñones-Aponte, Vicente, 1986, Water resources of the lower Río Grande de Arecibo alluvial valley, Puerto Rico: U.S. Geological Survey Water-Resources Investigations Report 85-4160, 38 p., 1 pl.

Quiñones-Aponte, Vicente, 1987, Effects of the channelization of Río Bucaná on the ground-water resources north of the Ponce Valley, Puerto Rico; Numerical analysis: Proceedings of the 12th Natural Resources Symposium, San Juan, Puerto Rico, December 11-12, 1985, Puerto Rico Department of Natural Resources (Published in Spanish), 4 p.

Quiñones-Aponte, Vicente, 1988, Effects of the horizontal anisotropy on the determination of storage coefficient [Abstract]: International Conference on Advances in Ground-Water Hydrology, Tampa, Florida, November 16-18, 1988, American Institute of Hydrology. 


\section{LIST OF PUBLICATIONS BY AUTHOR--Continued}

Quiñones-Aponte, Vicente, 1989, Comparison of aquifer storage coefficients computed using anisotropic and isotropic analytical models: Proceedings of the Recent Advances in Ground-Water Hydrology, American Institute of Hydrology, p. 349-357.

Quiñones-Aponte, Vicente, 1989, Horizontal Anisotropy of the principal ground-water flow zone in the Salinas alluvial fan, Puerto Rico: Ground Water Journal, v. 27, no. 4, p. 491-500.

Quiñones-Aponte, Vicente, 1989, Hydrogeologic characteristics of the lower Río Grande de Arecibo alluvial valley: Proceedings of the 13th Natural Resources Symposium, San Juan, Puerto Rico, February 26, 1987, Puerto Rico Department of Natural Resources, p. 41-59.

Quiñones-Aponte, Vicente, 1988, Recovery efficiency from single-well injection/recovery tests in a limestone aquifer of high secondary porosity: Proceedings of the American Society of Civil Engineers, Irrigation and Drainage Division, Artificial Recharge of Ground Water, International Symposium, Anaheim, California, August 1988, p. 54-63.

Quiñones-Aponte, Vicente, 1991, Water-resources development and its influence on the water budget for the aquifer system in the Salinas to Patillas area, Puerto Rico: in Gómez-Gómez, Fernando, Quiñones-Aponte, Vicente, and Johnson, A.I., eds., Aquifers of the Caribbean Islands, Proceedings of the International Symposium on Tropical Hydrology, San Juan, Puerto Rico, July 2327, 1990, AWRA Monograph Series no. 15, p. 37-55.

Quiñones-Aponte, Vicente, and Carrasquillo, R.A., 1986, Use of borehole neutron logs to estimate moisture content in the unsaturated zone of an alluvial aquifer: in Quiñones, Ferdinand, Sánchez, A.V., and Smith, H.H., eds., Proceedings of the Third Caribbean Islands Water-Resources Congress, U.S. Virgin Islands, July 22-25, 1986, Puerto Rico Water Resources Association, p. 57-60.

Quiñones-Aponte, Vicente, and Gómez-Gómez, Fernando, 1987, Potentiometric surface of the alluvial aquifer and hydrologic conditions in the Salinas quadrangle, Puerto Rico, March 1986: U.S. Geological Survey Water-Resources Investigations Report 87-4161, 1 sheet.

Quiñones-Aponte, Vicente, and Torres-Sierra, Heriberto, 1985, Application of a ground-water flow digital model in evaluating alternate dewatering systems in the Río Grande de Arecibo alluvial valley, Puerto Rico: Proceedings of the Tropical Hydrology and Second Caribbean Islands Water-Resources Congress, May 5-8, 1985, American Water Resources Association, Technical Publication Series TPS-85-1, p. 129-134.

Quiñones-Aponte, Vicente, Whitesides, D.V., and Zack, Allen, 1989, Single-well injection and recovery of freshwater from an aquifer containing saline water a t Arecibo, Puerto Rico: U.S. Geological Survey Water-Resources Investigations Report $88-4037,19 \mathrm{p}$.

Quiñones-Márquez, Ferdinand, 1973, Chemical-quality and flow-duration curves for selected streams in Puerto Rico: U.S. Geological Survey Open-File Report PR-7.

Quiñones-Márquez, Ferdinand, 1975, Chemical, biochemical, and bacteriological determinations at selected stream sites in Puerto Rico: U.S. Geological Survey Open-File Report 75-1, 118 p.

Quiñones-Márquez, Ferdinand, 1975, Chemical composition of rainfall at selected sites in Puerto Rico: U.S. Geological Survey Open-File Report 75-364, 17 p.

Quiñones-Márquez, Ferdinand, 1976, Chemical, physical, biochemical, and bacteriological determinations in Lago Loíza, Puerto Rico, and in its main tributaries, September 1973 - December 1974: U.S. Geological Survey Open-File Report 76-7, 74 p.

Quiñones-Márquez, Ferdinand, 1976, Chemical, physical, biochemical, and bacteriological determinations in Laguna Tortuguero, Puerto Rico, July 1974 - June 1975: U.S. Geological Survey Open-File Report 76-5, 39 p.

Quiñones-Márquez, Ferdinand, 1978, Selected chemical properties of rainfall in the Río Piedras basin, Puerto Rico: U.S. Geological Survey Open-File Report 78-159, 14 p.

Quiñones-Márquez, Ferdinand, 1980, Limnology of Lago Loíza, Puerto Rico: U.S. Geological Survey Water-Resources Investigations Report 79-97, $113 \mathrm{p}$.

Quiñones-Márquez, Ferdinand, 1981, Frecuencia de magnitud y flujos en los ríos principales de Puerto Rico: U.S. Geological Survey Open-File Data Report. 


\section{LIST OF PUBLICATIONS BY AUTHOR--Continued}

Quiñones-Márquez, Ferdinand, 1981, Ground-water levels in the south coast of Puerto Rico, February 1969-71: U.S. Geological Survey Open-File Data Report PR-1-71.

Quiñones-Márquez, Ferdinand, 1987, Management and development of surface and ground water: in Krushesky, R.D., ed., Proceedings of the Development of Mineral, Energy, and Water Resources and Mitigation of Geologic Hazards in Central America, U.S. Geological Survey Circular 1006, p. 140-149.

Quiñones-Márquez, Ferdinand, and Fusté, L.A., 1978, Limnology of Laguna Tortuguero, Puerto Rico: U.S. Geological Survey Water-Resources Investigations Report 77-122, 86 p.

Quiñones-Márquez, Ferdinand, and Peña-Cruz, Gilberto, 1985, Water resources investigations in Puerto Rico and the U.S. Virgin Islands - Programs and activities of the U.S. Geological Survey, Water Resources Division, Caribbean District 19841985: U.S. Geological Survey Open-File Report 85-556, 43 p.

Quiñones-Márquez, Ferdinand, Gómez-Gómez, Fernando, and Zack, Allen, 1984, Puerto Rico ground-water resources National Water Summary 1984: U.S. Geological Survey Water-Supply Paper 2275, p. 367-372.

Quiñones-Márquez, Ferdinand, Guzmán-Ríos, Senén, 1986, Determinación de caudal y técnicas de muestreo en agua superficial: U.S. Geological Survey Water-Resources Investigations Report 85-89, 68 p.

Quiñones-Márquez, Ferdinand, López, M.A., and Latkovich, V.J., 1976, Water records of the Río Piedras basin, Puerto Rico, 1971-74: U.S. Geological Survey Open-File Report 76-3, 111 p.

Quiñones-Márquez, Ferdinand, Vázquez, Pedro, and Peña, Rafael, 1977, Chemical, physical, biochemical, and bacteriological characteristics at selected stream sites in Puerto Rico, 1975-76: U.S. Geological Survey Open-File Report 77-237, 176 p.

Quiñones-Márquez, Ferdinand, Vázquez, Pedro, and Peña-Cortés, Rafael, 1978, Chemical, physical, biochemical, and bacteriological characteristics at selected stream sites in Puerto Rico 1976-77: U.S. Geological Survey Open-File Report 78$445,145 \mathrm{p}$.

Quiñones-Márquez, Ferdinand, Vázquez, Pedro, Class, Angel, and Peña, Rafael, 1976, Chemical, physical, biochemical, and bacteriological characteristics at selected stream sites in Puerto Rico, 1974-75: U.S. Geological Survey Open-File Report 76-1, $163 \mathrm{p}$.

Ramos-Ginés, Orlando, 1991, Elevation of water table and hydrologic conditions in the Río Lapa to Río Majada area, Puerto Rico, for December 1988, and April, July, and October 1989: U.S. Geological Survey Water-Resources Investigations Report 90-4125, 4 p., 1 sheet.

Reid, Ken, 1991, Cost-effectiveness of the stream-gaging program in Puerto Rico and the U.S. Virgin Islands: U.S. Geological Survey Water-Resources Investigations Report 90-4088, 32 p.

Renken, R.A., Barker, R.A., and Gómez-Gómez, Fernando, 1990, Basin analysis, paleoenvironment reconstruction and tectonic structures: Application of geologic interpretations to regional ground-water assessment in large sedimentary basins: Proceedings of the International Conference on Ground Water in Large Sedimentary Basins, Australia Water-Resources Council Conference Series no. 20, Perth, Western Australia, July 9-13, 1990, p. 80-88.

Renken, R.A., Díaz, Pedro, Gómez-Gómez, Fernando, and Quiñones-Aponte, Vicente, 1990, Hydrologic excursion to Puerto Rico's Southern Plain: U.S. Geological Survey Open-File Report 90-365, 24 p., 1 pl.

Renken, R.A., Gómez-Gómez, Fernando, Quiñones-Aponte, Vicente, and Dacosta, Rafael, 1991, Structure and depositional patterns and their influence on the hydraulic conductivity of fan-deltas in southern Puerto Rico: in Gómez-Gómez, Fernando, Quiñones-Aponte, Vicente, and Johnson, A.I., eds., Aquifers of the Caribbean Islands, Proceedings of the International Symposium on Tropical Hydrology, San Juan, Puerto Rico, July 23-27, 1990, AWRA Monograph Series no. 15, p. 25-36.

Richards, R.T., Troester, J.W., 1992, Using surface geophysical techniques to map the saline-freshwater interface and the depth to bedrock in the Valle de Yabucoa alluvial aquifer, Puerto Rico [Abstract]: Proceedings of the 17th Symposium of Natural Resources, San Juan, Puerto Rico, November 1991.

Rickler, J.G., and others, 1970, Water records of Puerto Rico, 1964-67, Volume 1, north and northeast slopes: U.S. Geological Survey Water-Data Report 71-238, 265 p. 


\section{LIST OF PUBLICATIONS BY AUTHOR--Continued}

Rickler, J.G., and others, 1970, Water records of Puerto Rico, 1964-67, Volume 2, south and west slopes: U.S. Geological Survey Water-Data Report, 308 p.

Robison, T.M., 1971, Earthquake-accelerated decline of water level in an observation well in St. Thomas, Virgin Islands: U.S. Geological Survey Professional Paper 750-B, p. 252-253.

Robison, T.M., 1972, Ground water in central St. Croix, U.S. Virgin Islands: U.S. Geological Survey Open-File Report, 18 p.

Robison, T.M., and Anders, R.B., 1973, Electric analog model study of the alluvial aquifer in the Yabucoa Valley, Puerto Rico (Phase 2--The planning, construction, and use of the model): U.S. Geological Survey Open-File Report 73-242, 47 p.

Robison, T.M., and others, 1972, Water records of the U.S. Virgin Islands, 1962-69: U.S. Geological Survey Water-Data Report, $163 \mathrm{p}$.

Rodríguez-del-Río, Félix, and Gómez-Gómez, Fernando, 1990, Potentiometric surface of the alluvial aquifer and hydrologic conditions in the Santa Isabel-Juana Díaz area, Puerto Rico, March to April 1987: U.S. Geological Survey Water-Resources Investigations Report 89-4116, 1 sheet.

Rodríguez-del-Río, Félix, and Quiñones-Aponte, Vicente, 1990, Potentiometric surface of the principal aquifer and hydrologic conditions in the Ponce-Juana Díaz area, Puerto Rico, April to May 1987: U.S. Geological Survey Water-Resources Investigations Report 89-4115, 1 sheet.

Rodríguez-Martínez, Jesús, 1991, The hydrogeologic framework of the Northern Coastal Province Aquifer System of Puerto Rico: in Gómez-Gómez, Fernando, Quiñones-Aponte, Vicente, and Johnson, A.I., eds., Aquifers of the Caribbean Islands, Proceedings of the International Symposium on Tropical Hydrology, San Juan, Puerto Rico, July 23-27, 1990: AWRA Monograph Series no. 15 , p. $5-16$.

Rodríguez-Martínez, Jesús, Hartley, J.L.*, and Torres-González, Arturo, 1991, Geologic and hydrologic data collected at test well NC-5, Barceloneta, Puerto Rico: U.S. Geological Survey Open-File Report 90-390, 30 p.

Rodríguez-Martínez, Jesús, Scharlach, R.A.*, and Torres-González, Arturo, 1991, Geologic and hydrologic data collected at test holes NC-1 and NC-3, Guaynabo and San Juan, eastern Puerto Rico: U.S. Geological Survey Open-File Report 91-217, $20 \mathrm{p}$.

Rodríguez-Martínez, Jesús, Scharlach, R.A.*, and Torres-González, Arturo, 1992, Geologic and hydrologic data collected at test holes NC-4 and NC-14, Manatí and Vega Baja, Puerto Rico: U.S. Geological Survey Open-File Report 92-126, 31 p.

Rolón-Collazo, L.I., and González, Philip, 1990, An interactive computer program, GWARC, to create a geographic information system data set from ground-water site inventory data [Abstract]: National Computer Technology Meeting, May 7-11, 1990, Programs and Abstracts, U.S. Geological Survey Open-File Report 90-161, p. 34.

Román-Más, Angel, 1986, Role of blanket deposits on the hydrology and water chemistry of the limestone water-table aquifer within the north coast of Puerto Rico through interpretation of geochemical data: in Quiñones, Ferdinand, Sánchez, A.V., and Smith, H.H., eds., Proceedings of the Third Caribbean Islands Water-Resources Congress, U.S. Virgin Islands, July 22-25, 1986, Puerto Rico Water Resources Association, p. 33.

Román-Más, Angel, 1986, Role of climatic data in determining the water required, used, and supplied for irrigation in the ricegrowing areas along the north coast of Puerto Rico [Abstract]: Conference on Climate and Water Management - A Critical Era, American Meteorological Society, August 4-7, 1986, p. 1-9.

Román-Más, Angel, 1988, Water required, water used, and potential water sources for rice irrigation, north coast of Puerto Rico: U.S. Geological Survey Water-Resources Investigations Report 86-4334, 35 p.

Román-Más, Angel, and Green, Bruce, 1987, Climatological data for the rice-growing areas along the north coast of Puerto Rico: U.S. Geological Survey Open-File Data Report 86-53, 90 p.

Román-Más, Angel, and Lee, R.W., 1985, Water quality and chemical evolution of ground water within the north coast limestone aquifers of Puerto Rico: Proceedings of the Tropical Hydrology and Second Caribbean Islands Water-Resources Congress, May 5-8, 1985, American Water Resources Association, Technical Publication Series TPS-85-1, p. 57-63. 


\section{LIST OF PUBLICATIONS BY AUTHOR--Continued}

Román-Más, Angel, and Lee, R.W., 1987, Geochemical evolution of waters within the north coast limestone aquifers of Puerto Rico: A conceptualization based on a flow path in the Barceloneta area: U.S. Geological Survey Water-Resources Investigations Report 86-4080, 28 p.

Román-Más, Angel, and Ramos-Ginés, Orlando, 1987, Elevation of the water-table surface for the alluvial aquifer and hydrologic conditions in the Santa Isabel-Juana Díaz area, Puerto Rico, March 1986: U.S. Geological Survey Water-Resources Investigations Report 87-4123, 2 sheets.

Román-Más, Angel, and Ramos-Ginés, Orlando, 1988, Compilation of water-quality data for the north coast limestone aquifers, Puerto Rico, 1951 to 1987: U.S. Geological Survey Open-File Data Report 87-533, 133 p.

Santiago-Rivera, Luis, 1992, Low-flow characteristics at selected sites on streams in eastern Puerto Rico: U.S. Geological Survey Water-Resources Investigations Report 92-4063, 46 p.

Santiago-Rivera, Luis, and Colón-Dieppa, Eloy, 1986, U.S. Virgin Islands surface-water resources - National Water Summary 1985: U.S. Geological Survey Water-Supply Paper 2300, p. 447-452.

Scatena, F.N.*, and Larsen, M.C., 1991, Physical aspects of Hurricane Hugo in Puerto Rico: Biotropica, v. 23, no. 4A, p. 317-323.

Schuck-Kolben, R.E., and Kaufman, Lionel, 1991, Storm-surge flooding by Hurricane Hugo on the U.S. Virgin Islands, Puerto Rico, and South Carolina, September 1989 - National Water Summary 1988-89: U.S. Geological Survey Water-Supply Paper 2375, p. 59-64.

Sepulveda, Nicasio, 1991, Solution of the one-dimensional consolidation theory equation with a Pseudospectral Method: Proceedings of the Fourth International Association of Hydrological Sciences, Symposium on Land Subsidence, Houston, Texas, IAHS no. 200, p. 555-564.

Sépulveda, Nicasio, 1992, Computer algorithm for the analysis of underdamped and overdamped water-level responses in slug tests: U.S. Geological Survey Water Resources-Investigations Report 91-4162, 20 p.

Sepulveda, Nicasio, and Zack, A.L., 1990, Laboratory simulation of the effects of overburden stress on the specific storage of shallow artesian aquifers: in Krishna, J.H., Quiñones-Aponte, Vicente, Gómez-Gómez, Fernando, and Morris, G.L., eds., Tropical Hydrology and Caribbean Water Resources, Proceedings of the International Symposium on Tropical Hydrology, San Juan, Puerto Rico, July 23-27, 1990, AWRA TPS-90-2, p. 349-356.

Simon, Andrew, and Larsen, M.C., 1988, Shear strength and slope stability at sites in the Caribbean National Forest and Coamo area, Puerto Rico [Abstract]: The Geological Society of America, Abstracts with Programs, v. 20, no. 7, p. A144.

Simon, Andrew, Larsen, M.C., and Hupp, C.R., 1990, The role of soil processes in determining mechanisms of slope failure and hillslope development in a himid-tropical forest, eastern, Puerto Rico: in Kneupfer , P.L.D. and McFadden, L.D., eds., Soils and Landscape Evolution, Geomorphology, 3(1990), p. 263-286.

Stevens, K.E., Gómez-Gómez, Fernando, and Alicea, José, 1981, Water wells in the U.S. Virgin Islands, Part 1, St. Thomas: U.S. Geological Survey Open-File Report 82-82, 112 p.

Torres-González, Arturo, 1981, Hydrology of the Río Camuy caves system, Puerto Rico [Abstract]: Proceedings of the Eighth International Congress of Speleology, July 18-24, 1981, Kentucky, no. 8, p. 475.

Torres-González, Arturo, 1985, Simulation of ground-water flow in the water table aquifer near Barceloneta, Puerto Rico: U.S. Geological Survey Water-Resources Investigations Report 84-4113, 39 p.

Torres-González, Arturo, 1985, Use of surface-geophysical techniques for ground-water exploration in the Canóvanas-Río Grande area, Puerto Rico: U.S. Geological Survey Water-Resources Investigations Report 83-4266, 29 p.

Torres-González, Arturo, and Díaz, J.R., 1984, Water resources of the Sabana Seca to Vega Baja area, Puerto Rico: U.S. Geological Survey Water-Resources Investigations Report 82-4115, 53 p.

Torres-González, Arturo, and Gómez-Gómez, Fernando, 1982, Geohydrologic descriptions of selected solid-waste disposal sites in Puerto Rico: U.S. Geological Survey Open-File Report 81-490, 146 p. 


\section{LIST OF PUBLICATIONS BY AUTHOR--Continued}

Torres-González, Arturo, and Wolansky, R.M., 1984, Planning report for the comprehensive appraisal of the ground-water resources of the north coast limestone area of Puerto Rico: U.S. Geological Survey Open-File Data Report 84-427, 32 p.

Torres-González, Sigfredo, 1984, Water-resources investigations of Vieques Island, Puerto Rico: Proceedings of the First Caribbean Islands Water-Resources Congress, St. Thomas, U.S. Virgin Islands, July 26-27, 1984, p. 298-311.

Torres-González, Sigfredo, 1989, Reconnaissance of the ground-water resources of Vieques Island, Puerto Rico: U.S. Geological Survey Water-Resources Investigations Report 86-4100, 37 p.

Torres-González, Sigfredo, 1991, Compilation of ground-water level measurements obtained by the United States Geological Survey in Puerto Rico, 1958-1985: U.S. Geological Survey Open-File Data Report 88-701, 163 p.

Torres-González, Sigfredo, 1991, Steady-state simulation of ground-water flow conditions in the Kingshill aquifer, St. Croix, U.S. Virgin Islands, July 1987: in Gómez-Gómez, Fernando, Quiñones-Aponte, Vicente, and Johnson, A.I., eds., Aquifers of the Caribbean Islands, Proceedings of the International Symposium on Tropical Hydrology, San Juan, Puerto Rico, July 23-27, 1990, AWRA Monograph Series no. 15, p. 93-108.

Torres-González, Sigfredo, and Gómez-Gómez, Fernando, 1987, Potentiometric surface of the alluvial aquifer and hydrologic conditions in the Central Aguirre quadrangle, Puerto Rico, March 1986: U.S. Geological Survey Water-Resources Investigations Report 87-4160, 1 sheet.

Torres-González, Sigfredo, and Rodríguez-del-Río, Félix, 1990, Potentiometric surface of the Kingshill aquifer and hydrologic conditions, St. Croix, U.S. Virgin Islands, July 1987: U.S. Geological Survey Water-Resources Investigations Report 89-4085, 1 sheet.

Torres-González, Sigfredo, and Rolón-Collazo, L.I., 1990, The interactive computer program MODUMANAG, a data management tool for the modular finite-difference ground-water flow model: in Krishna, J.H., Quiñones-Aponte, Vicente, Gómez-Gómez, Fernando, and Morris, G.L., eds., Tropical Hydrology and Caribbean Water Resources, Proceedings of the International Symposium on Tropical Hydrology, San Juan, Puerto Rico, July 23-27, 1990, AWRA TPS-90-2, p. 403-410.

Torres-Sierra, Heriberto, 1985, Potentiometric surface of the upper limestone aquifer in the Dorado-Vega Alta area, north-central Puerto Rico, February 1983: U.S. Geological Survey Water-Resources Investigations Report 85-4268, 1 sheet.

Torres-Sierra, Heriberto, 1986, Estimated water use in St. Croix, U.S. Virgin Islands, 1983-1985: in Quiñones, Ferdinand, Sánchez, A.V., and Smith, H.H., eds., Proceedings of the Third Caribbean Islands Water-Resources Congress, U.S. Virgin Islands, July 22-25, 1986, Puerto Rico Water Resources Association, p. 7-11.

Torres-Sierra, Heriberto, 1987, Estimated water use in St. Croix, U.S. Virgin Islands, October 1983 - September 1985: U.S. Geological Survey Open-File Data Report 86-537, 1 sheet.

Torres-Sierra, Heriberto, and Avilés, Ada*, 1986, Estimated water use in Puerto Rico, 1980-82: U.S. Geological Survey OpenFile Data Report 85-557, 77 p.

Torres-Sierra, Heriberto, and Dacosta, Rafael, 1984, Estimated water use in St. Thomas, U.S. Virgin Islands, July 1983 - June 1984: U.S. Geological Survey Open-File Data Report 84-721, 1 sheet.

Troester, J.W., 1988, U.S. Geological Survey ground-water studies in Puerto Rico: U.S. Geological Survey Water Fact Sheet, Open-File Report 88-162, 2 p.

Troester, J.W., 1988, U.S. Geological Survey ground-water studies in the U.S. Virgin Islands: U.S. Geological Survey Water Fact Sheet, Open-File Report 88-163, 2 p.

Troester, J.W., 1990, Hydrogeologic processes in the northern karst belt of Puerto Rico: A humid tropical karst [Abstract]: Proceedings of the International Symposium and Field Seminar on Hydrogeologic Processes in Karst Terranes, Antalya, Turkey, October 7-17, 1990, p. 116-117.

Troester, J.W., 1992, The northern karst belt of Puerto Rico: A Humid Tropical Karst: in Back, William, Herman, J.S., and Paloc, Henri, eds., Hydrogeology of Selected Karst Regions, International Association of Hydrogeologists, v. 13, p. 475-486. 


\section{LIST OF PUBLICATIONS BY AUTHOR--Continued}

Troester, J.W., 1992, Wind as a hydrogeologic agent and cultural factor in the Lesser Antilles [Abstract]: The Geologic Society of America, Abstracts with Programs, v. 24, no. 7, p. A68.

Troester, J.W., and Moore, J.E., 1989, Karst hydrogeology in the United States of America: Episodes, v. 12, no. 3, p. 172-178.

Troester, J.W., and White, W.B.*, 1988, River knickpoints, uplift, and tilting in the northern karst belt of Puerto Rico [Abstract]: The Geological Society of America, Abstracts with Programs, v. 20, no. 7, p. 307.

Troester, J.W., and White, W.B.*, 1988, The carbonate chemistry of the Río Camuy drainage basin, Puerto Rico: A Humid Tropical Karst [Abstract]: National Speleological Society, Annual Convention Program, p. 34

Troester, J.W., and White, W.B.*, 1989, Carbonate chemistry and hydrogeology of Río Camuy drainage basin, Puerto Rico [Abstract]: Humid Tropical Karst 28th International Geologic Congress, Washington D.C., July 9-19, 1989, v. 3, p. 255.

Troester, J.W., Back, William, and Mora, S.C.*, 1987, Karst of the Caribbean: in Graf, W.L., Geomorphic Systems of North America: The Geological Society of America, DNAG (Decade of North American Geology) Centennial Special Volume no. 2 , p. 343-402.

Troester, J.W., Collar, P.D., Robinson, P.D.*, and Deike, R.G., 1990, Geochemical processes controlling manganese and iron concentrations in the ground water of the Valle de Yabucoa alluvial aquifer, Puerto Rico [Abstract]: EOS, Transactions, American Geophysical Union, April 24, 1990, v. 71, no. 17, p. 506.

Troester, J.W., Deike, R.G., Robinson, P.D.*, and Collar, P.D., 1990, Petrographic analyses and geochemical modeling of aquequs/solid phase reactions in the Valle de Yabucoa alluvial aquifer, Puerto Rico [Abstract]: The Geological Society of America, Abstracts with Programs, p. A295.

U.S. Geological Survey, 1973, Water resources data for Puerto Rico, 1968, Part 1, Surface water records: U.S. Geological Survey Water-Data Report, 87 p.

U.S. Geological Survey, 1973, Water resources data for Puerto Rico, 1968, Part 2, Surface water records: U.S. Geological Survey Water-Data Report, 87 p.

U.S. Geological Survey, 1973, Water resources data for Puerto Rico, 1968-72, Part 3, Ground water records: U.S. Geological Survey Water-Data Report, 78 p.

U.S. Geological Survey, 1973, Water resources data for Puerto Rico, 1969, Part 1, Surface water records: U.S. Geological Survey Water-Data Report, 89 p.

U.S. Geological Survey, 1973, Water resources data for Puerto Rico, 1970, Part 1, Surface water records: U.S. Geological Survey Water-Data Report, 90 p.

U.S. Geological Survey, 1973, Water resources data for Puerto Rico, 1971, Part 1, Surface water records: U.S. Geological Survey Water-Data Report, 72 p.

U.S. Geological Survey, 1974, Water resources data for Puerto Rico, 1972, Part 1, Surface water records: U.S. Geological Survey Water-Data Report, 70 p.

U.S. Geological Survey, 1974, Water resources data for Puerto Rico, 1968-72, Part 2A, Water quality records: U.S. Geological Survey Water-Data Report, 410 p.

U.S. Geological Survey, 1975, Water resources data for Puerto Rico, 1973, Part 1, Surface water records: U.S. Geological Survey Water-Data Report, 69 p.

U.S. Geological Survey, 1975, Water resources data for Puerto Rico, 1973, Part 2, Water quality records: U.S. Geological Survey Water-Data Report, 133 p.

U.S. Geological Survey, 1975, Water resources data for Puerto Rico, 1968-72, Part 2B, Water quality records (sediment): U.S. Geological Survey Water-Data Report, 182 p.

U.S. Geological Survey, 1976, Water resources data for Puerto Rico, 1974, Part 1, Surface water records: U.S. Geological Survey Water-Data Report, 66 p. 


\section{LIST OF PUBLICATIONS BY AUTHOR--Continued}

U.S. Geological Survey, 1976, Water resources data for Puerto Rico, 1974, Part 2, Water quality records: U.S. Geological Survey Water-Data Report, 158 p.

U.S. Geological Survey, 1978, Water resources data for Puerto Rico, Surface and quality-of-water records, Water Years 1975-76, Ground water records, Water Years 1973-76: U.S. Geological Survey Water-Data Report-PR-76-1, 366 p.

U.S. Geological Survey, 1979, Water-resources investigations in Puerto Rico and the U.S. Virgin Islands, 1978: U.S. Geological Survey Folder.

U.S. Geological Survey, 1980, Water resources data for Puerto Rico, Surface and quality-of-water records, Water Year 1977, Ground water records, Water Year 1977: U.S. Geological Survey Water-Data Report PR-77-1, 215 p.

U.S. Geological Survey, 1981, Water resources data for Puerto Rico, Water Year 1978: U.S. Geological Survey Water-Data Report PR-78-1, 255 p.

U.S. Geological Survey, 1982, Water resources data for Puerto Rico, Water Years 1979-80: U.S. Geological Survey Water-Data Report PR-79-80, 408 p.

U.S. Geological Survey, 1983, Puerto Rico and the U.S. Virgin Islands water issues: National Water Summary 1983 - Hydrologic Events and Issues, U.S. Geological Survey Water-Supply Paper 2250, p. 200-202.

Vaughan, T.W., 1920, The ground-water resources of the West Indian Islands, St. John, St. Thomas, Culebra and Vieques, and of the eastern end of Puerto Rico: U.S. Geological Survey Open-File Report.

Veve, T.D., and Troester, J.W., 1990, Water-resources investigations in Puerto Rico and the U.S. Virgin Islands, 1986-1988: U.S. Geologic Survey Open-File Report 90-122, 39 p.

Ward, P.E., and Jordan, D.G., 1963, Water resources of the Virgin Islands, A preliminary appraisal, 1963: U.S. Geological Survey Open-File Report, 44 p.

Ward, P.E., and Truxes, C.S., 1964, Water wells in Puerto Rico: U.S. Geological Survey Water-Resources Bulletin 3, 249 p.

Whitesides, D.V., Quiñones-Aponte, Vicente, and Zack, A.L., 1985, Estimating the capacity of a salty limestone aquifer in Puerto Rico to receive, store, and release injected freshwater using chloride mass balance: Proceedings of the Second Caribbean Islands Water-Resources Congress and Tropical Hydrology, May 5-8, 1985, American Water Resources Association, Technical Publication Series TPS-85-1, p. 50-55.

Wilson, A., and Iseri, K.T., 1967, River discharge to the sea from the shores of the conterminous United States, Alaska, and Puerto Rico: U.S. Geological Survey Hydrology Investigations Atlas HA-282, 1 sheet.

Wilson, H.M., 1899, Water resources of Puerto Rico: U.S. Geological Survey Water-Supply Paper 32.

Woodward, T.H., and Heidel, S.G., 1964, Inventory of published and unpublished chemical analyses of surface waters in the continental United States and Puerto Rico, 1961: U.S. Geological Survey Water-Supply Paper 1786, 490 p.

Yuan, Daoxian*, and Troester, J.W., 1990, Evidence of climatic control on hydrogeologic processes in the karst terranes of Central China and Puerto Rico [Abstract]: Proceedings of the International Symposium and Field Seminar on Hydrogeological Processes in Karst Terranes, Antalya, Turkey, October 7-17, 1990, p. 120-121.

Zack, A.L., 1985, Effects of sand removal on the Camuy Mangrove Forest, Puerto Rico: U.S. Geological Survey Water-Supply Paper 2254.

Zack, A.L., 1988, A well system to recover usable water from a freshwater-saltwater aquifer in Puerto Rico: U.S. Geological Survey Water-Supply Paper 2328, 15 p.

Zack, A.L., and Class-Cacho, Angel, 1984, Restoration of freshwater in the Caño Tiburones area, Puerto Rico: U.S. Geological Survey Water-Resources Investigations Report 83-4071, 33 p., 1 pl.

Zack, A.L., Rodríguez-Alonso, Teresita, and Román-Más, Angel, 1987, Puerto Rico ground-water quality - National Water Summary: U.S. Geological Survey Water-Supply Paper 2325, p. 437-442. 


\section{LIST OF PUBLICATIONS BY AUTHOR--Continued}

Zack, A.L., Rodríguez-Alonso, Teresita, and Román-Más, Angel, 1987, U.S. Virgin Islands ground-water quality - National Water Summary: U.S. Geological Survey Water-Supply Paper 2325, p. 489-492.

Zack, Allen, 1984, Use of scavenger-production well couples to optimize withdrawal of freshwater from saline aquifers in Puerto Rico: Proceedings of the First Caribbean Islands Water-Resources Congress, St. Thomas, U.S. Virgin Islands, July 26-27, 1984, p. 312-336.

Zack, Allen, 1986, Effects of sand removal on the shallow aquifer in the vicinity of the Camuy Mangrove Forest, Puerto Rico: in Quiñones, Ferdinand, Sánchez, A.V., and Smith, H.H., eds., Proceedings of the Third Caribbean Islands Water-Resources Congress, U.S. Virgin Islands, July 22-25, 1986, Puerto Rico Water Resources Association, p. 41-48.

Zack, Allen, and Román-Más, Angel, 1988, Hydrology of the Caribbean Islands Wetlands: Proceedings of the Caribbean Islands Wetlands Workshop, Forestry \& Wildlife Management Institute, University of Massachusetts at Amherst, October 28-29, 1986, p. 65-73. 
(BLANK)

3

Publications of the U.S. Geological Survey, Water Resources Division, for Puerto Rico and the U.S. Virgin Islands, $1899-1992$ 


\section{PUBLICATIONS BY MUNICIPIO IN PUERTO RICO}




\section{PUBLICATIONS BY MUNICIPIO IN PUERTO RICO}

\section{Aguada}

Johnson, K.G., 1972, Floods in the Aguadilla-Aguada area, northwestern Puerto Rico: U.S. Geological Survey Hydrologic Investigations Atlas HA- 457,1 sheet.

\section{Aguadilla}

Johnson, K.G., 1972, Floods in the Aguadilla-Aguada area, northwestern Puerto Rico: U.S. Geological Survey Hydrologic Investigations Atlas HA- 457,1 sheet.

\section{Añasco}

Díaz, J.R., and Jordan, D.G., 1987, Water resources of the Río Grande de Añasco - lower valley, Puerto Rico: U.S. Geological Survey WaterResources Investigations Report 85-4237, 48 p.

Fields, F.K., 1971, Floods in the Añasco area, Puerto Rico: U.S. Geological Survey Hydrologic Investigations Atlas HA-375, 1 sheet.

Johnson, K.G., and Quiñones-Aponte, Vicente, 1982, Flood of September 16, 1975, in the Añasco area, Puerto Rico: U.S. Geological Survey Open-File Report 81-345, 1 sheet.

Menoyo, L.E., 1992, Using a microcomputer to create an animated three-dimensional visualization of Bahía de Añasco, Puerto Rico [Abstract]: Joint U.S. Geological Survey/Jet Propulsion Laboratory Scientific Visualization Workshop, Program and Abstracts, Norfolk, Virginia, May 1819, 1992, p. 22.

\section{Arecibo}

Arnow, Ted, 1961, Water bearing properties of the rocks in the Arecibo-Barceloneta area, Puerto Rico: in Short Papers in the Geologic and Hydrologic Sciences, Articles 147-292, Geological Survey Research 1961, U.S. Geological Survey Professional Paper 424-C, Article 221, p. 201-202.

Díaz, J.R., 1973, Chemical quality of water in Caño Tiburones, Puerto Rico: A reconnaissance study carried out in 1967: U.S. Geological Survey Open-File Report Map Series no. 2, 2 pls.

Hickenlooper, I.J., 1968, Floods at Arecibo, Puerto Rico: U.S. Geological Survey Hydrologic Investigations Atlas HA-271, 1 sheet.

Quiñones, Ferdinand, Meléndez, Frank, and Bonnet, Carlos, 1989, Sedimentation survey of Lago Dos Bocas, Puerto Rico, June 1985: U.S. Geological Survey Open-File Report 86-241, 14 p.

Quiñones-Aponte, Vicente, 1986, Water resources of the lower Río Grande de Arecibo alluvial valley, Puerto Rico: U.S. Geological Survey Water-Resources Investigations Report 85-4160, 38 p., 1 pl.

Quiñones-Aponte, Vicente, 1989, Hydrogeologic characteristics of the lower Río Grande de Arecibo alluvial valley: Proceedings of the 13th Natural Resources Symposium, San Juan, Puerto Rico, February 26, 1987, Puerto Rico Department of Natural Resources, p. 41-59.

Quiñones-Aponte, Vicente, and Torres-Sierra, Heriberto, 1985, Application of a ground-water flow digital model in evaluating alternate dewatering systems in the Río Grande de Arecibo alluvial valley, Puerto Rico: Proceedings of the Tropical Hydrology and Second Caribbean Islands Water-Resources Congress, May 5-8, 1985, American Water Resources Association, Technical Publication Series TPS-85-1, p. 129-134.

Quiñones-Aponte, Vicente, Whitesides, D.V., and Zack, Allen, 1989, Single-well injection and recovery of freshwater from an aquifer containing saline water at Arecibo, Puerto Rico: U.S. Geological Survey Water-Resources Investigations Report 88-4037, 19 p.

Zack, A.L., and Class-Cacho, Angel, 1984, Restoration of freshwater in the Caño Tiburones area, Puerto Rico: U.S. Geological Survey WaterResources Investigations Report 83-4071, 33 p., 1 pl.

\section{Arroyo}

Dacosta, Rafael, and Gómez-Gómez, Fernando, 1987, Potentiometric surface of the alluvial aquifer and hydrologic conditions in the Guayama quadrangle, Puerto Rico, March 1986: U.S. Geological Survey Water-Resources Investigations Report 87-4162, 1 sheet. 


\section{Barceloneta}

Arnow, Ted, 1961, Water bearing properties of the rocks in the Arecibo-Barceloneta area, Puerto Rico: in Short Papers in the Geologic and Hydrologic Sciences, Articles 147-292, Geological Survey Research 1961, U.S. Geological Survey Professional Paper 424-C, Article 221, p. 201-202.

Díaz, J.R., 1973, Chemical quality of water in Caño Tiburones, Puerto Rico: A reconnaissance study carried out in 1967: U.S. Geological Survey Open-File Report Map Series no. 2, 2 pls.

Gómez-Gómez, Fernando, 1984, Water resources of the lower Río Grande de Manatí Valley: U.S. Geological Survey Water-Resources Investigations Report 83-4199, 42 p.

Hickenlooper, I.J., 1967, Floods at Barceloneta and Manatí, Puerto Rico: U.S. Geological Survey Hydrologic Investigations Atlas HA-262, 1 pl.

Rodríguez-Martínez, Jesús, Hartley, J.L., and Torres-González, Arturo, 1991, Geologic and hydrologic data collected at test well NC-5, Barceloneta, Puerto Rico: U.S. Geological Survey Open-File Report 90-390, 30 p.

Román-Más, Angel, and Lee, R.W., 1987, Geochemical evolution of waters within the north coast limestone aquifers of Puerto Rico: A conceptualization based on a flow path in the Barceloneta area: U.S. Geological Survey Water-Resources Investigations Report 86-4080, $28 \mathrm{p}$.

Torres-González, Arturo, 1985, Simulation of ground-water flow in the water table aquifer near Barceloneta, Puerto Rico: U.S. Geological Survey Water-Resources Investigations Report 84-4113, 39 p.

Zack, A.L., and Class-Cacho, Angel, 1984, Restoration of freshwater in the Caño Tiburones area, Puerto Rico: U.S. Geological Survey WaterResources Investigations Report 83-4071, 33 p., 1 pl.

\section{Bayamón}

López, M.A., 1962, Floods at Bayamón and Cataño, Puerto Rico: U.S. Geological Survey Hydrologic Investigations Atlas HA-77, 1 sheet.

\section{Cabo Rojo}

Anders, R.B., 1968, Reconnaissance of the water resources of the Central Guanajibo Valley, Cabo Rojo, Puerto Rico: U.S. Geological Survey Open-File Report, 15 p.

Colón-Dieppa, Eloy, and Quiñones-Marquéz, Ferdinand, 1985, A reconnaissance of the water resources of the Central Río Guanajibo Valley, Puerto Rico: U.S. Geological Survey Water-Resources Investigations Report 82-4050, 47 p.

Haire, W.J., 1972, Floods in the Río Guanajibo Valley, southwestern Puerto Rico: U.S. Geological Survey Hydrologic Investigations Atlas HA456,1 sheet.

Johnson, K.G., 1982, Flood of September 16, 1975, in the Guanajibo Valley, Puerto Rico: U.S. Geological Survey Open-File Report 81-805, 1 sheet.

\section{Caguas}

Collar, P.D., 1991, Fluvial metal transport during a storm event, Río Grande de Loíza basin, Puerto Rico [Abstract]: The Geological Society of America, Abstracts with Programs, v. 23, no. 5, p. 203.

Collar, P.D., and Guzmán-Ríos, Senén, 1991, Sedimentation rates and capacity restoration options, Lago Loíza, Puerto Rico: in Drs. Shou-Shan Fan and Yung-Huang Kuo, eds., Proceedings of the Fifth Federal Interagency Sedimentation Conference, Las Vegas, Nevada, March 18-21, 1991 , v. 2, p. $15-17$ to $15-25$.

Fields, F.K., 1972, Floods at Caguas, Gurabo, Juncos, and San Lorenzo, Puerto Rico: U.S. Geological Survey Hydrologic Investigations Atlas HA-438, 1 sheet.

Guzmán-Ríos, Senén, 1989, Suspended-sediment data in the upper Río Grande de Loíza basin, Puerto Rico: U.S. Geological Survey Open-File Data Report 88-324, 42 p.

Puig, J.C., Rodríguez-del-Río, Félix, and Rodríguez, J.M., 1989, Potentiometric surface of the alluvial aquifer and hydrologic conditions near Caguas, Puerto Rico, March 1988: U.S. Geological Survey Water-Resources Investigations Report 89-4075, 1 sheet.

Quiñones, Ferdinand, Green, Bruce, and Santiago, Luis, 1989, Sedimentation survey of Lago Loíza, Puerto Rico, July 1985: U.S. Geological Survey Water-Resources Investigations Report 87-4019, 17 p. 


\section{Caguas--Continued}

Quiñones-Márquez, Ferdinand, 1976, Chemical, physical, biochemical, and bacteriological determinations in Lago Loíza, Puerto Rico, and in its main tributaries, September 1973 - December 1974: U.S. Geological Survey Open-File Report 76-7, 74 p.

Quiñones-Márquez, Ferdinand, 1980, Limnology of Lago Loíza, Puerto Rico: U.S. Geological Survey Water-Resources Investigations Report $79.97,113 \mathrm{p}$.

\section{Camuy}

Torres-González, Arturo, 1981, Hydrology of the Río Camuy caves system, Puerto Rico [Abstract]: Proceedings of the Eighth International Congress of Speleology, July 18-24, 1981, Kentucky, no. 8, p. 475.

Troester, J.W., and White, W.B., 1988, The carbonate chemistry of the Río Camuy drainage basin, Puerto Rico: A Humid Tropical Karst [Abstract]: National Speleological Society, Annual Convention Program, 34 p.

Troester, J.W., and White, W.B., 1989, Carbonate chemistry and hydrogeology of Río Camuy drainage basin, Puerto Rico [Abstract]: Humid Tropical Karst 28th International Geologic Congress, Washington D.C., July 9-19, 1989, v. 3, p. 255.

Zack, A.L., 1985, Effects of sand removal on the Camuy Mangrove Forest, Puerto Rico: U.S. Geological Survey Water-Supply Paper 2254.

Zack, Allen, 1986, Effects of sand removal on the shallow aquifer in the vicinity of the Camuy Mangrove Forest, Puerto Rico: in Quiñones, Ferdinand, Sánchez, A.V., and Smith, H.H., eds., Proceedings of the Third Caribbean Islands Water-Resources Congress, U.S. Virgin Islands, July 22-25, 1986, Puerto Rico Water Resources Association, p. 41-48.

\section{Canóvanas}

Haire, W.J., 1975, Floods in the Carolina-Río Grande area, northeastern Puerto Rico: U.S. Geological Survey Hydrologic Investigations Atlas HA-533, 1 sheet.

Torres-González, Arturo, 1985, Use of surface-geophysical techniques for ground-water exploration in the Canóvanas-Río Grande area, Puerto Rico: U.S. Geological Survey Water-Resources Investigations Report 83-4266, 29 p.

\section{Carolina}

Collar, P.D., 1991, Fluvial metal transport during a storm event, Río Grande de Loíza basin, Puerto Rico [Abstract]: The Geological Society of America, Abstracts with Programs, v. 23, no. 5, p. 203.

Guzmán-Ríos, Senén, 1989, Suspended-sediment data in the upper Río Grande de Loíza basin, Puerto Rico: U.S. Geological Survey Open-File Data Report 88-324, 42 p.

Haire, W.J., 1975, Floods in the Carolina-Río Grande area, northeastern Puerto Rico: U.S. Geological Survey Hydrologic Investigations Atlas HA-533, 1 sheet.

Quiñones-Márquez, Ferdinand, 1976, Chemical, physical, biochemical, and bacteriological determinations in Lago Loíza, Puerto Rico, and in its main tributaries, September 1973 - December 1974: U.S. Geological Survey Open-File Report 76-7, 74 p.

\section{Cataño}

López, M.A., 1962, Floods at Bayamón and Cataño, Puerto Rico: U.S. Geological Survey Hydrologic Investigations Atlas HA-77, 1 sheet.

\section{Ciales}

Ellins, K.K., Román-Más, Angel, and Lee, R.N., 1986, Estimating ground-water influx to a portion of the Río Grande de Manatí River basin in Puerto Rico through the measurement of ${ }^{222} \mathrm{Rn}$ : in Quiñones, Ferdinand, Sánchez, A.V., and Smith, H.H., eds., Proceedings of the Third Caribbean Islands Water-Resources Congress, U.S. Virgin Islands, July 22-25, 1986, Puerto Rico Water Resources Association, p. 27.

Gómez-Gómez, Fernando, 1984, Water resources of the lower Río Grande de Manatí Valley: U.S. Geological Survey Water-Resources Investigations Report 83-4199, 42 p. 


\section{Coamo}

Giusti, E.V., 1971, Regional specific yield of the Coamo Fan, Puerto Rico, computed by the water budget method: in Geological Survey Research 1971, Chap. B, U.S. Geological Survey Professional Paper 750-B, p. 248-251.

Giusti, E.V., 1971, Water resources of the Coamo area, Puerto Rico: U.S. Geological Survey Water-Resources Bulletin 9, 31 p.

Johnson, K.G., Quiñones, Ferdinand, and González, Ralph, 1987, Hydraulic analyses of water-surface profiles in the vicinity of the Coamo Dam and Highway 52 bridge, southern Puerto Rico; Flood analyses as related to the flood of October 7, 1985: U.S. Geological Survey WaterResources Investigations Report 87-4039, 26 p.

Simon, Andrew, and Larsen, M.C., 1988, Shear strength and slope stability at sites in the Caribbean National Forest and Coamo area, Puerto Rico [Abstract]: The Geological Society of America, Abstracts with Programs, v. 20, no. 7, p. A-144.

\section{Culebra}

Briggs, R.P., and Akers, J.P., 1965, Hydrogeologic map of Puerto Rico and adjacent islands: U.S. Geological Survey Hydrologic Investigations Atlas HA-197, 1 sheet.

Jordan, D.G., and Gilbert, B.K., 1976, Water supply and waste disposal, Culebra, Puerto Rico: U.S. Geological Survey Water-Resources Investigations $76-3,31 \mathrm{p}$.

Vaughan, T.W., 1920, The ground-water resources of the West Indian Islands, St. John, St. Thomas, Culebra and Vieques, and of the eastern end of Puerto Rico: U.S. Geological Survey Open-File Report.

\section{Dorado}

G6mez-Gómez, Fernando, and Torres-Sierra, Heriberto, 1988, Hydrology and effects of development on the water-table aquifer in the Vega Alta quadrangle, Puerto Rico: U.S. Geological Survey Water-Resources Investigations Report 87-4105, 54 p.

López, M.A., 1964, Floods at Toa Alta, Toa Baja, and Dorado, Puerto Rico: U.S. Geological Survey Hydrologic Investigations Atlas HA-128, 1 sheet.

Torres-González, Arturo, and Díaz, J.R., 1984, Water resources of the Sabana Seca to Vega Baja area, Puerto Rico: U.S. Geological Survey Water-Resources Investigations Report 82-4115, 53 p.

Torres-Sierra, Heriberto, 1985, Potentiometric surface of the upper limestone aquifer in the Dorado-Vega Alta area, north-central Puerto Rico, February 1983: U.S. Geological Survey Water-Resources Investigations Report 85-4268, 1 sheet.

\section{Fajardo}

Haire, W.J., 1975, Floods in the Fajardo-Luquillo area, northeastern Puerto Rico: U.S. Geological Survey Hydrologic Investigations Atlas HA545,1 sheet.

\section{Guánica}

Graves, R.P., 1991, Ground-water resources in Lajas Valley, Puerto Rico: U.S. Geological Survey Water-Resources Investigations Report $89-4182,55 \mathrm{p}$.

Grossman, I.G., 1963, Geology of the Guánica-Guayanilla bay area, southwestern Puerto Rico: in Short Papers in Geology and Hydrology, Articles 1-59, U.S. Geological Survey Professional Paper 475-B, Article 29, p. 114-116.

Johnson, K.G., 1974, Floods in eastern Lajas Valley and the lower Río Loco basin, southwestern Puerto Rico: U.S. Geological Survey Hydrologic Investigations Atlas HA-532, 1 sheet.

Johnson, K.G., and González, Ralph, 1982, Flood of September 16, 1975, in the Guánica area, Puerto Rico: U.S. Geological Survey Open-File Report 81-480, 1 sheet.

McClymonds, N.E., 1967, Water resources of the Guánica area, Puerto Rico - A preliminary appraisal, 1963: U.S. Geological Survey WaterResources Bulletin 6, 43 p.

\section{Guayama}

Dacosta, Rafael, and Gómez-G6mez, Fernando, 1987, Potentiometric surface of the alluvial aquifer and hydrologic conditions in the Guayama quadrangle, Puerto Rico, March 1986: U.S. Geological Survey Water-Resources Investigations Report 87-4162, 1 sheet. 


\section{Guayama--Continued}

Díaz, J.R., 1971, Electric analog model study of water in the Guayama area, Puerto Rico (Phase-1, Assembling data for the analog model): U.S. Geological Survey Open-File Report 71-86, 68 p.

Graves, R.P., 1992, Geohydrology of the Aguirre and Pozo Hondo areas, southern Puerto Rico: U.S. Geological Survey Water-Resources Investigations Report 91-4124, 43 p.

Haire, W.J., 1971, Floods in the Guayama area, Puerto Rico: U.S. Geological Survey Hydrologic Investigations Atlas HA-446, 1 sheet.

McClymonds, N.E., and Díaz, J.R., 1972, Water resources of the Jobos area, Puerto Rico - A preliminary appraisal, 1962: U.S. Geological Survey Water-Resources Bulletin 13, 32 p.

Torres-González, Sigfredo, and Gómez-Gómez, Fernando, 1987, Potentiometric surface of the alluvial aquifer and hydrologic conditions in the Central Aguirre quadrangle, Puerto Rico, March 1986: U.S. Geological Survey Water-Resources Investigations Report 87-4160, 1 sheet.

\section{Guayanilla}

Conde-Costas, Carlos, and Troester, J.W., 1988, The effects of bat guano on carbonate chemistry in Cueva El Convento, Guayanilla, Puerto Rico [Abstract]: National Speleological Society, Forty-Fifth Annual Convention Program, Hot Spring, South Dakota, June 27 to July 1, 1988, p. 34 .

Crooks, J.W., Grossman, I.G., and Bogart, D.B., 1968, Water resources of the Guayanilla-Yauco area, Puerto Rico: U.S. Geological Survey Water-Resources Bulletin 5, 55 p., 7 pis.

Fields, F.K., 1971, Floods in the Guayanilla-Yauco area, Puerto Rico: U.S. Geological Survey Hydrologic Investigations Atlas HA-414, 1 sheet.

Grossman, I.G., 1963, Geology of the Guánica-Guayanilla bay area, southwestern Puerto Rico: in Short Papers in Geology and Hydrology, Articles 1-59, U.S. Geological Survey Professional Paper 475-B, Article 29, p. 114-116.

Johnson, K.G., 1982, Flood of September 16, 1975, in the Guayanilla Valley, Puerto Rico: U.S. Geological Survey Open-File Report 80-1282, 1 sheet.

\section{Guaynabo}

Rodríguez-Martínez, Jesús, Scharlach, R.A., and Torres-González, Arturo, 1991, Geologic and hydrologic data collected at test holes NC-1 and NC-3, Guaynabo and San Juan, eastern Puerto Rico: U.S. Geological Survey Open-File Report 91-217, 20 p.

\section{Gurabo}

Collar, P.D., 1991, Fluvial metal transport during a storm event, Río Grande de Loíza basin, Puerto Rico [Abstract]: The Geological Society of America, Abstracts with Programs, v. 23, no. 5, p. 203.

Collar, P.D., and Guzmán-Ríos, Senén, 1991, Sedimentation rates and capacity restoration options, Lago Loíza, Puerto Rico: in Drs. Shou-Shan Fan and Yung-Huang Kuo, eds., Proceedings of the Fifth Federal Interagency Sedimentation Conference, Las Vegas, Nevada, March 18-21, 1991 , v. 2, p. $15-17$ to $15-25$.

Fields, F.K., 1972, Floods at Caguas, Gurabo, Juncos, and San Lorenzo, Puerto Rico: U.S. Geological Survey Hydrologic Investigations Atlas HA-438, 1 sheet.

Guzmán-Ríos, Senén, 1989, Suspended-sediment data in the upper Río Grande de Loíza basin, Puerto Rico: U.S. Geological Survey Open-File Data Report 88-324, 42 p.

Puig, J.C., and Rodríguez, J.M., 1990, Potentiometric surface of the aliuvial aquifer and hydrologic conditions near Gurabo and Juncos, Puerto Rico, March 1988: U.S. Geological Survey Water-Resources Investigations Report 90-4059, 2 sheets.

Quiñones, Ferdinand, Green, Bruce, and Santiago, Luis, 1989, Sedimentation survey of Lago Loíza, Puerto Rico, July 1985: U.S. Geological Survey Water-Resources Investigations Report 87-4019, $17 \mathrm{p}$.

Quiñones-Márquez, Ferdinand, 1976, Chemical, physical, biochemical, and bacteriological determinations in Lago Loíza, Puerto Rico, and in its main tributaries, September 1973 - December 1974: U.S. Geological Survey Open-File Report 76-7, 74 p.

Quiñones-Márquez, Ferdinand, 1980, Limnology of Lago Loíza, Puerto Rico: U.S. Geological Survey Water-Resources Investigations Report $79-97,113 \mathrm{p}$. 


\section{Hatillo}

Torres-González, Arturo, 1981, Hydrology of the Río Camuy caves system, Puerto Rico [Abstract]: Proceedings of the Eighth International Congress of Speleology, July 18-24, 1981, Kentucky, no. 8, p. 475.

Troester, J.W., and White, W.B., 1988, The carbonate chemistry of the Río Camuy drainage basin, Puerto Rico: A Humid Tropical Karst [Abstract]: National Speleological Society, Annual Convention Program, 34 p.

Troester, J.W., and White, W.B., 1989, Carbonate chemistry and hydrogeology of Río Camuy drainage basin, Puerto Rico [Abstract]: Humid Tropical Karst 28th International Geologic Congress, Washington D.C., July 9-19, 1989, v. 3, p. 255.

\section{Hormigueros}

Anders, R.B., 1968, Reconnaissance of the water resources of the Central Guanajibo Valley, Cabo Rojo, Puerto Rico: U.S. Geological Survey Open-File Report, 15 p.

Colón-Dieppa, Eloy, and Quiñones-Marquéz, Ferdinand, 1985, A reconnaissance of the water resources of the Central Río Guanajibo Valley, Puerto Rico: U.S. Geological Survey Water-Resources Investigations Report 82-4050, 47 p.

Haire, W.J., 1972, Floods in the Río Guanajibo Valley, southwestern Puerto Rico: U.S. Geological Survey Hydrologic Investigations Atlas HA-456, 1 sheet.

Johnson, K.G., 1982, Flood of September 16, 1975, in the Guanajibo Valley, Puerto Rico: U.S. Geological Survey Open-File Report 81-805, 1 sheet.

\section{Humacao}

Graves, R.P., 1989, Water resources of the Humacao-Naguabo area, eastern Puerto Rico: U.S. Geological Survey Water-Resources Investigations Report 87-4088, 69 p.

López, M.A., 1967, Floods at Humacao, Puerto Rico: U.S. Geological Survey Hydrologic Investigations Atlas HA-265, 1 sheet.

\section{Jayuya}

Johnson, K.G., and Carrasquillo, R.A., 1982, Floods of October 9, 1970, and September 16, 1975, at Jayuya, Puerto Rico: U.S. Geological Survey Open-File Report 81-346, 1 sheet.

\section{Juana Díaz}

Figueroa-Alamo, Carlos, 1991, Sedimentation survey of Lago Toa Vaca, Puerto Rico, July 1985: U.S. Geological Survey Open-File Report 90-199, 9 p.

Giusti, E.V., 1968, Water resources of the Juana Díaz area, Puerto Rico - A preliminary appraisal, 1966: U.S. Geological Survey WaterResources Bulletin 8, 43 p.

Grossman, I.G., 1962, Stratigraphy and hydrology of the Juana Díaz Formation in the Yauco area, Puerto Rico: in Short Papers in Geology, Hydrology, and Topography, Articles 120-179, U.S. Geological Survey Professional Paper 450-D, Article 137, p. 62-63.

Rodríguez-del-Río, Félix, and Gómez-Gómez, Fernando, 1990, Potentiometric surface of the alluvial aquifer and hydrologic conditions in the Santa Isabel-Juana Díaz area, Puerto Rico, March to April 1987: U.S. Geological Survey Water-Resources Investigations Report 89-4116, 1 sheet.

Rodríguez-del-Río, Félix, and Quiñones-Aponte, Vicente, 1990, Potentiometric surface of the principal aquifer and hydrologic conditions in the Ponce-Juana Díaz area, Puerto Rico, April to May 1987: U.S. Geological Survey Water-Resources Investigations Report 89-4115, 1 sheet.

Román-Más, Angel, and Ramos-Ginés, Orlando, 1987, Elevation of the water-table surface for the alluvial aquifer and hydrologic conditions in the Santa Isabel-Juana Díaz area, Puerto Rico, March 1986: U.S. Geological Survey Water-Resources Investigations Report 87-4123, 2 sheets. 


\section{Juncos}

Collar, P.D., 1991, Fluvial metal transport during a storm event, Río Grande de Loíza basin, Puerto Rico [Abstract]: The Geological Society of America, Abstracts with Programs, v. 23, no. 5, p. 203.

Fields, F.K., 1972, Floods at Caguas, Gurabo, Juncos, and San Lorenzo, Puerto Rico: U.S. Geological Survey Hydrologic Investigations Atlas HA-438, 1 sheet.

Guzmán-Ríos, Senén, 1989, Suspended-sediment data in the upper Río Grande de Loíza basin, Puerto Rico: U.S. Geological Survey Open-File Data Report 88-324, 42 p.

Puig, J.C., and Rodríguez, J.M., 1990, Potentiometric surface of the alluvial aquifer and hydrologic conditions near Gurabo and Juncos, Puerto Rico, March 1988: U.S. Geological Survey Water-Resources Investigations Report 90-4059, 2 sheets.

\section{Lajas}

Anderson, H.R., 1977, Ground water in the Lajas Valley, Puerto Rico: U.S. Geological Survey Water-Resources Investigations Report 68-76, 45 p.

Graves, R.P., 1991, Ground-water resources in Lajas Valley, Puerto Rico: U.S. Geological Survey Water-Resources Investigations Report $89-4182,55 \mathrm{p}$.

Johnson, K.G., 1974, Floods in eastern Lajas Valley and the lower Río Loco basin, southwestern Puerto Rico: U.S. Geological Survey Hydrologic Investigations Atlas HA-532, 1 sheet.

\section{Lares}

Troester, J.W., and White, W.B., 1988, The carbonate chemistry of the Río Camuy drainage basin, Puerto Rico: A Humid Tropical Karst [Abstract]: National Speleological Society, Annual Convention Program, 34 p.

Troester, J.W., and White, W.B., 1989, Carbonate chemistry and hdrogeology of Río Camuy drainage basin, Puerto Rico [Abstract]: Humid Tropical Karst 28th International Geologic Congress, Washington D.C., July 9-19, 1989, v. 3, p. 255.

\section{Las Piedras}

Collar, P.D., 1991, Fluvial metal transport during a storm event, Río Grande de Loíza basin, Puerto Rico [Abstract]: The Geological Society of America, Abstracts with Programs, v. 23, no. 5, p. 203.

Guzmán-Ríos, Senén, 1989, Suspended-sediment data in the upper Río Grande de Loíza basin, Puerto Rico: U.S. Geological Survey Open-File Data Report 88-324, 42 p.

\section{Luquillo}

Guariguata, M.R., and Larsen, M.C., 1990, Preliminary map showing locations of landslides in El Yunque quadrangle, Puerto Rico: U.S. Geological Survey Open-File Report 89-257, 1 sheet.

Haire, W.J., 1975, Floods in the Fajardo-Luquillo area, northeastern Puerto Rico: U.S. Geological Survey Hydrologic Investigations Atlas HA $-545,1$ sheet.

Larsen, M.C., 1990, Landslides caused by the intense precipitation of Hurricane Hugo in El Yunque and surrounding areas: Boletín Oficial de la Sociedad de Historia Natural de Puerto Rico, v. 24, no. 12, p. 8.

Larsen, M.C., 1991, Mass wasting disturbance and denudation in a humid-tropical montane forest, Puerto Rico [Abstract]: The Geological Society of America, Abstracts with Programs, v. 23, no. 5, p. A256.

Larsen, M.C., and Simon, Andrew, 1990, Landslide processes in saprolitic soils of a tropical rain forest, Puerto Rico: in Larue, D.K., and Draper, G., eds., Transactions of the 12th Caribbean Geological Conference, St. Croix, U.S. Virgin Islands, Miami Geological Society, p. $217-222$.

Larsen, M.C., and Torres-Sánchez, A.J., 1990, Rainfall-soil moisture relations in landslide-prone areas of a tropical rain forest, Puerto Rico: in Krishna, J.H., Quiñones-Aponte, Vicente, Gómez-Gómez, Fernando, and Morris, G.L., eds., Tropical Hydrology and Caribbean Water Resources, Proceedings of the International Symposium on Tropical Hydrology, San Juan, Puerto Rico, July 23-27, 1990, AWRA TPS-90-2, p. 121-129. 


\section{Manatí}

Bennett, G.D., and Giusti, E.V., 1972, Ground water in the Tortuguero area, Puerto Rico - As related to proposed harbor construction U.S. Geological Survey Water-Resources Bulletin 10, 25 p.

Ellins, K.K., Román-Más, Angel, and Lee, R.N., 1986, Estimating ground-water influx to a portion of the Río Grande de Manati River hasin in Puerto Rico through the measurement of ${ }^{222} \mathrm{Rn}$ : in Quiñones, Ferdinand, Sánchez, A.V., and Smith, H.H., eds., Proceedings of the Third Caribbean Islands Water-Resources Congress, U.S. Virgin Islands, July 22-25, 1986, Puerto Rico Water Resources Association, p. 27.

Gómez-Gómez, Fernando, 1984, Water resources of the lower Río Grande de Manatí Valley: U.S. Geological Survey Water-Resnurcés Investigations Report 83-4199, $42 \mathrm{p}$.

Hickenlooper, I.J., 1967, Floods at Barceloneta and Manatí, Puerto Rico: U.S. Geological Survey Hydrologic Investigations Atlas HA-262. 1 pl.

Quiñones-Márquez, Ferdinand, 1976, Chemical, physical, biochemical, and bacteriological determinations in Laguna Tortuguero, Puerto Rico, July 1974 - June 1975: U.S. Geological Survey Open-File Report 76-5, 39 p.

Quiñones-Márquez, Ferdinand, and Fusté, L.A., 1978, Limnology of Laguna Tortuguero, Puerto Rico: U.S. Geological Survey WaterResources Investigations Report 77-122, $86 \mathrm{p}$.

Rodríguez-Martínez, Jesús, Scharlach, R.A., and Torres-González, Arturo, 1992, Geologic and hydrologic data collected at test holes NC-4 and NC-14, Manatí and Vega Baja, Puerto Rico: U.S. Geological Survey Open-File Report 92-126, 31 p.

\section{Maunabo}

Adolphson, D.G., Seijo, M.A., and Robison, T.M., 1977, Water resources of the Maunabo Valley, Puerto Rico: U.S. Geological Survey WaterResources Investigations Report 115-76, 38 p.

Haire, W.J., 1971, Floods in the Patillas-Maunabo area, Puerto Rico: U.S. Geological Survey Hydrologic Investigations Atlas HA-445, I sheet

\section{Mayagüez}

Hickenlooper, I.J., 1968, Floods in the Mayagüez area of Puerto Rico: U.S. Geological Survey Hydrologic Investigations Atlas HA-288, I sheet.

\section{Naguabo}

Graves, R.P., 1989, Water resources of the Humacao-Naguabo area, eastern Puerto Rico: U.S. Geological Survey Water-Resources Investigaticns Report 87-4088, $69 \mathrm{p}$.

Haire, W.J., 1978, Floods in the Naguabo area, eastern Puerto Rico: U.S. Geological Survey Hydrologic Investigations Atlas HA-584, 1 sheet.

\section{Patillas}

Haire, W.J., 1971, Floods in the Patillas-Maunabo area, Puerto Rico: U.S. Geological Survey Hydrologic Investigations Atlas HA-445, 1 sheet.

Quiñones-Aponte, Vicente, 1991, Water-resources development and its influence on the water budget for the aquifer system in the Salinas to Patillas area, Puerto Rico: in Gómez-Gómez, Fernando, Quiñones-Aponte, Vicente, and Johnson, A.I., eds., Aquifers oi the Caribbean Islands, Proceedings of the International Symposium on Tropical Hydrology, San Juan, Puerto Rico, July 23-27, 1990, AWRA Monograph Series no. 15, p. $37-55$.

\section{Peñuelas}

Grossman, I.G., 1961, Ground-water conditions in the lower Tallaboa Valley, Puerto Rico: in Short Papers in the Geologic and Hydrologic Sciences, Articles 147-292, U.S. Geological Survey Professional Paper 424-C, Article 222, p. 202-203.

Grossman, I.G., Bogart, D.B., Crooks, J.W., and Díaz, J.R., 1972, Water resources of the Tallaboa Valley, Puerto Rico: U.S. Geological Survey Water-Resources Bulletin 7, 115 p.

Johnson, K.G., 1981, Flood of September 16, 1975, in Tallaboa Valley, Puerto Rico: U.S. Geological Survey Open-File Report 80-1283, 5 sheets. 


\section{Ponce}

Bennett, G.D., 1972, Ground water along Río Bucaná at Ponce, Puerto Rico - An d the effects of a proposed floodway on ground-water quality: U.S. Geological Survey Water-Resources Bulletin 11, 29 p.

Bennett, G.D., and Giusti, E.V., 1971, Coastal ground-water flow near Ponce, Puerto Rico: in Geological Survey Research 1971, Chap. D, U.S. Geological Survey Professional Paper 750-D, p. 206-211.

Hickenlooper, I.J., and López, M.A., 1967, Floods in the Ponce area, Puerto Rico: U.S. Geological Survey Hydrologic Investigations Atlas HA-261, 1 sheet.

McClymonds, N.E., 1972, Water resources of the Ponce area, Puerto Rico: U.S. Geological Survey Water-Resources Bulletin 14, 26 p.

Quiñones-Aponte, Vicente, 1987, Effects of the channelization of Río Bucaná on the ground-water resources north of the Ponce Valley, Puerto Rico; Numerical analysis: Proceedings of the 12th Natural Resources Symposium, San Juan, Puerto Rico, December 11-12, 1985, Puerto Rico Department of Natural Resources (Published in Spanish), 4 p.

Rodríguez-del-Río, Félix, and Quiñones-Aponte, Vicente, 1990, Potentiometric surface of the principal aquifer and hydrologic conditions in the Ponce-Juana Díaz area, Puerto Rico, April to May 1987: U.S. Geological Survey Water-Resources Investigations Report 89-4115, 1 sheet.

\section{Río Grande}

Guariguata, M.R., and Larsen, M.C., 1990, Preliminary map showing locations of landslides in El Yunque quadrangle, Puerto Rico: U.S. Geological Survey Open-File Report 89-257, 1 sheet.

Haire, W.J., 1975, Floods in the Carolina-Río Grande area, northeastern Puerto Rico: U.S. Geological Survey Hydrologic Investigations Atlas HA-533, 1 sheet.

Larsen, M.C., 1990, Landslides caused by the intense precipitation of Hurricane Hugo in El Yunque and surrounding areas: Boletín Oficial de la Sociedad de Historia Natural de Puerto Rico, v. 24, no. 12, p. 8.

Larsen, M.C., 1991, Mass wasting disturbance and denudation in a humid-tropical montane forest, Puerto Rico [Abstract]: The Geological Society of America, Abstracts with Programs, v. 23, no. 5, p. A256.

Larsen, M.C., and Simon, Andrew, 1990, Landslide processes in saprolitic soils of a tropical rain forest, Puerto Rico: in Larue, D.K., and Draper, G., eds., Transactions of the 12th Caribbean Geological Conference, St. Croix, U.S. Virgin Islands, Miami Geological Society, p. $217-222$.

Larsen, M.C., and Torres-Sánchez, A.J., 1990, Rainfall-soil moisture relations in landslide-prone areas of a tropical rain forest, Puerto Rico: in Krishna, J.H., Quiñones-Aponte, Vicente, Gómez-Gómez, Fernando, and Morris, G.L., eds., Tropical Hydrology and Caribbean Water Resources, Proceedings of the International Symposium on Tropical Hydrology, San Juan, Puerto Rico, July 23-27, 1990, AWRA TPS-90-2, p. 121-129.

Simon, Andrew, and Larsen, M.C., 1988, Shear strength and slope stability at sites in the Caribbean National Forest and Coamo area, Puerto Rico [Abstract]: The Geological Society of America, Abstracts with Programs, v. 20, no. 7, p. A144.

Torres-González, Arturo, 1985, Use of surface-geophysical techniques for ground-water exploration in the Canóvanas-Río Grande area, Puerto Rico: U.S. Geological Survey Water-Resources Investigations Report 83-4266, 29 p.

\section{Sabana Grande}

Anders, R.B., 1968, Reconnaissance of the water resources of the Central Guanajibo Valley, Cabo Rojo, Puerto Rico: U.S. Geological Survey Open-File Report, 15 p.

Colón-Dieppa, Eloy, and Quiñones-Marquéz, Ferdinand, 1985, A reconnaissance of the water resources of the Central Río Guanajibo Valley, Puerto Rico: U.S. Geological Survey Water-Resources Investigations Report 82-4050, 47 p.

Haire, W.J., 1972, Floods in the Río Guanajibo Valley, southwestern Puerto Rico: U.S. Geological Survey Hydrologic Investigations Atlas HA456,1 sheet.

Johnson, K.G., 1982, Flood of September 16, 1975, in the Guayanilla Valley, Puerto Rico: U.S. Geological Survey Open-File Report 80-1282, 1 sheet. 


\section{Salinas}

Graves, R.P., 1992, Geohydrology of the Aguirre and Pozo Hondo areas, southern Puerto Rico: U.S. Geological Survey Water-Resources Investigations Report 91-4124, 43 p.

Haire, W.J., 1971, Floods in Salinas area, Puerto Rico: U.S. Geological Survey Hydrologic Investigations Atlas HA-447, 1 sheet.

McClymonds, N.E., and Ward, P.E., 1966, Hydrologic characteristics of the alluvial fan near Salinas, Puerto Rico: in Geological Survey Research 1966, Chap. C, U.S. Geological Survey Professional Paper 550-C, p. 231-234.

Quiñones-Aponte, Vicente, 1989, Horizontal Anisotropy of the principal ground-water flow zone in the Salinas alluvial fan, Puerto Rico: Ground Water Journal, v. 27, no. 4, p. 491-500.

Quiñones-Aponte, Vicente, 1991, Water-resources development and its influence on the water budget for the aquifer system in the Salinas to Patillas area, Puerto Rico: in Gómez-Gómez, Fernando, Quiñones-Aponte, Vicente, and Johnson, A.I., eds., Aquifers of the Caribbean Islands, Proceedings of the International Symposium on Tropical Hydrology, San Juan, Puerto Rico, July 23-27, 1990, AWRA Monograph Series no. 15, p. $37-55$.

Quiñones-Aponte, Vicente, and Gómez-Gómez, Fernando, 1987, Potentiometric surface of the alluvial aquifer and hydrologic conditions in the Salinas quadrangle, Puerto Rico, March 1986: U.S. Geological Survey Water-Resources Investigations Report 87-4161, 1 sheet.

Ramos-Ginés, Orlando, 1991, Elevation of water table and hydrologic conditions in the Río Lapa to Río Majada area, Puerto Rico, for December 1988, and April, July, and October 1989: U.S. Geological Survey Water-Resources Investigations Report 90-4125, 4 p., 1 sheet.

Torres-González, Sigfredo, and Gómez-Gómez, Fernando, 1987, Potentiometric surface of the alluvial aquifer and hydrologic conditions in the Central Aguirre quadrangle, Puerto Rico, March 1986: U.S. Geological Survey Water-Resources Investigations Report 87-4160, 1 sheet.

\section{San Germán}

Anders, R.B., 1968, Reconnaissance of the water resources of the Central Guanajibo Valley, Cabo Rojo, Puerto Rico: U.S. Geological Survey Open-File Report, 15 p.

Colón-Dieppa, Eloy, and Quiñones-Marquéz, Ferdinand, 1985, A reconnaissance of the water resources of the Central Río Guanajibo Valley, Puerto Rico: U.S. Geological Survey Water-Resources Investigations Report 82-4050, 47 p.

Haire, W.J., 1972, Floods in the Río Guanajibo Valley, southwestern Puerto Rico: U.S. Geological Survey Hydrologic Investigations Atlas HA456,1 sheet.

Johnson, K.G., 1982, Flood of September 16, 1975, in the Guayanilla Valley, Puerto Rico: U.S. Geological Survey Open-File Report 80-1282, 1 sheet.

\section{San Juan}

Anderson, H.R., 1976, Ground water in the San Juan Metropolitan area, Puerto Rico: U.S. Geological Survey Water-Resources Investigations Report 75-41, 34 p.

Ellis, S.R., 1976, History of dredging and filling of lagoons in the San Juan area, Puerto Rico: U.S. Geological Survey Water-Resources Investigations Report 76-38, 25 p., 4 pls.

Ellis, S.R., and Gómez-Gómez, Fernando, 1975, Water-quality and hydraulic data, San Juan lagoon system, Puerto Rico: U.S. Geological Survey Open-File Report 75-2-PR, 142 p.

Ellis, S.R., and Gómez-Gómez, Fernando, 1976, Hydrologic characteristics of lagoons at San Juan, Puerto Rico, during a January 1974 tidal cycle: U.S. Geological Survey Water-Resources Investigations Report 75-38, 45 p.

Gómez-Gómez, Fernando, Quiñones, Ferdinand, and Ellis, S.R., 1983, Hydrologic characteristics of lagoons at San Juan, Puerto Rico, during an October 1974 tidal cycle: U.S. Geological Survey Open-File Report 82-349, 34 p.

Haire, W.J., 1971, Flooding along the Río Piedras in the San Juan area, Puerto Rico: U.S. Geological Survey Hydrologic Investigations Map Series no. 1,2 sheets.

Rodríguez-Martínez, Jesús, Scharlach, R.A., and Torres-González, Arturo, 1991, Geologic and hydrologic data collected at test holes NC-1 and NC-3, Guaynabo and San Juan, eastern Puerto Rico: U.S. Geological Survey Open-File Report 91-217, 20 p. 


\section{San Lorenzo}

Fields, F.K., 1972, Floods at Caguas, Gurabo, Juncos, and San Lorenzo, Puerto Rico: U.S. Geological Survey Hydrologic Investigations Atlas HA-438, 1 sheet.

Guzmán-Ríos, Senén, 1989, Suspended-sediment data in the upper Río Grande de Loíza basin, Puerto Rico: U.S. Geological Survey Open-File Data Report 88-324, 42 p.

\section{Santa Isabel}

Haire, W.J., 1971, Floods in the Santa Isabel area, Puerto Rico: U.S. Geological Survey Hydrologic Investigations Atlas HA-448, 1 sheet.

Rodríguez-del-Rio, Félix, and Gómez-Gómez, Fernando, 1990, Potentiometric surface of the alluvial aquifer and hydrologic conditions in the Santa Isabel-Juana Díaz area, Puerto Rico, March to April 1987: U.S. Geological Survey Water-Resources Investigations Report 89-4116, 1 sheet.

Román-Más, Angel, and Ramos-Ginés, Orlando, 1987, Elevation of the water-table surface for the alluvial aquifer and hydrologic conditions in the Santa Isabel-Juana Díaz area, Puerto Rico, March 1986: U.S. Geological Survey Water-Resources Investigations Report 87-4123, 2 sheets.

\section{Toa Alta}

López, M.A., 1964, Floods at Toa Alta, Toa Baja, and Dorado, Puerto Rico: U.S. Geological Survey Hydrologic Investigations Atlas HA-128, 1 sheet.

\section{Toa Baja}

López, M.A., 1964, Floods at Toa Alta, Toa Baja, and Dorado, Puerto Rico: U.S. Geological Survey Hydrologic Investigations Atlas HA-128, 1 sheet.

Gómez-Gómez, Fernando, and Torres-Sierra, Heriberto, 1988, Hydrology and effects of development on the water-table aquifer in the Vega Alta quadrangle, Puerto Rico: U.S. Geological Survey Water-Resources Investigations Report 87-4105, 54 p.

Torres-González, Arturo, and Díaz, J.R., 1984, Water resources of the Sabana Seca to Vega Baja area, Puerto Rico: U.S. Geological Survey Water-Resources Investigations Report 82-4115, 53 p.

\section{Trujillo Alto}

Collar, P.D., 1991, Fluvial metal transport during a storm event, Río Grande de Loíza basin, Puerto Rico [Abstract]: The Geological Society of America, Abstracts with Programs, v. 23, no. 5, p. 203.

Collar, P.D., and Guzmán-Ríos, Senén, 1991, Sedimentation rates and capacity restoration options, Lago Loíza, Puerto Rico: in Drs. Shou-Shan Fan and Yung-Huang Kuo, eds., Proceedings of the Fifth Federal Interagency Sedimentation Conference, Las Vegas, Nevada, March 18-21, 1991 , v. 2, p. $15-17$ to $15-25$.

Guzmán-Ríos, Senén, 1989, Suspended-sediment data in the upper Río Grande de Loíza basin, Puerto Rico: U.S. Geological Survey Open-File Data Report 88-324, 42 p.

Quiñones, Ferdinand, Green, Bruce, and Santiago, Luis, 1989, Sedimentation survey of Lago Loíza, Puerto Rico, July 1985: U.S. Geological Survey Water-Resources Investigations Report 87-4019, 17 p.

Quiñones-Márquez, Ferdinand, 1976, Chemical, physical, biochemical, and bacteriological determinations in Lago Loíza, Puerto Rico, and in its main tributaries, September 1973 - December 1974: U.S. Geological Survey Open-File Report 76-7, 74 p.

Quiñones-Márquez, Ferdinand, 1978, Selected chemical properties of rainfall in the Río Piedras basin, Puerto Rico: U.S. Geological Survey Open-File Report 78-159, 14 p.

Quiñones-Márquez, Ferdinand, 1980, Limnology of Lago Loíza, Puerto Rico: U.S. Geological Survey Water-Resources Investigations Report $79-97,113 \mathrm{p}$.

Quiñones-Márquez, Ferdinand, López, M.A., and Latkovich, V.J., 1976, Water records of the Río Piedras basin, Puerto Rico, 1971-74: U.S. Geological Survey Open-File Report 76-3, 111 p. 


\section{Utuado}

Johnson, K.G., Quiñones, Ferdinand, and Alicea, José, 1982, Flood of September 16, 1975, at Utuado, Puerto Rico: U.S. Geological Survey Open-File Report 81-413, 1 sheet.

Jordan, D.G., 1970, Water and copper-mine tailings in karst terrane of Río Tanamá basin, Puerto Rico: U.S. Geological Survey Open-File Report 71-163, $24 \mathrm{p}$.

Quiñones, Ferdinand, Meléndez, Frank, and Bonnet, Carlos, 1989, Sedimentation survey of Lago Dos Bocas, Puerto Rico, June 1985: U.S. Geological Survey Open-File Report 86-241, 14 p.

Troester, J.W., and White, W.B., 1988, The carbonate chemistry of the Río Camuy drainage basin, Puerto Rico: A Humid Tropical Karst [Abstract]: National Speleological Society, Annual Convention Program, $34 \mathrm{p}$.

Troester, J.W., and White, W.B., 1989, Carbonate chemistry and hydrogeology of Río Camuy drainage basin, Puerto Rico [Abstract]: Humid Tropical Karst 28th International Geologic Congress, Washington D.C., July 9-19, 1989, v. 3, p. 255.

\section{Vega Alta}

Gómez-Gómez, Fernando, and Torres-Sierra, Heriberto, 1988, Hydrology and effects of development on the water-table aquifer in the Vega Alta quadrangle, Puerto Rico: U.S. Geological Survey Water-Resources Investigations Report 87-4105, 54 p.

Hickenlooper, I.J., 1968, Floods in the area of Vega Alta and Vega Baja, Puerto Rico: U.S. Geological Survey Hydrologic Investigations Atlas HA-289, 1 sheet.

Torres-González, Arturo, and Díaz, J.R., 1984, Water resources of the Sabana Seca to Vega Baja area, Puerto Rico: U.S. Geological Survey Water-Resources Investigations Report 82-4115, 53 p.

Torres-Sierra, Heriberto, 1985, Potentiometric surface of the upper limestone aquifer in the Dorado-Vega Alta area, north-central Puerto Rico, February 1983: U.S. Geological Survey Water-Resources Investigations Report 85-4268, 1 sheet.

\section{Vega Baja}

Bennett, G.D., and Giusti, E.V., 1972, Ground water in the Tortuguero area, Puerto Rico - As related to proposed harbor construction: U.S. Geological Survey Water-Resources Bulletin 10, 25 p.

Gómez-Gómez, Fernando, and Torres-Sierra, Heriberto, 1988, Hydrology and effects of development on the water-table aquifer in the Vega Alta quadrangle, Puerto Rico: U.S. Geological Survey Water-Resources Investigations Report 87-4105, 54 p.

Hickenlooper, I.J., 1968, Floods in the area of Vega Alta and Vega Baja, Puerto Rico: U.S. Geological Survey Hydrologic Investigations Atlas HA-289, 1 sheet.

Quiñones-Márquez, Ferdinand, 1976, Chemical, physical, biochemical, and bacteriological determinations in Laguna Tortuguero, Puerto Rico, July 1974 - June 1975: U.S. Geological Survey Open-File Report 76-5, 39 p.

Quiñones-Márquez, Ferdinand, and Fusté, L.A., 1978, Limnology of Laguna Tortuguero, Puerto Rico: U.S. Geological Survey WaterResources Investigations Report 77-122, 86 p.

Rodríguez-Martínez, Jesús, Scharlach, R.A., and Torres-González, Arturo, 1992, Geologic and hydrologic data collected at test holes NC-4 and NC-14, Manatí and Vega Baja, Puerto Rico: U.S. Geological Survey Open-File Report 92-126, 31 p.

Torres-González, Arturo, and Díaz, J.R., 1984, Water resources of the Sabana Seca to Vega Baja area, Puerto Rico: U.S. Geological Survey Water-Resources Investigations Report 82-4115, 53 p.

\section{Vieques}

McGuinness, C.L., 1946, Ground-water reconnaissance of Vieques Island, Puerto Rico: U.S. Geological Survey Open-File Report.

Torres-González, Sigfredo, 1984, Water-resources investigations of Vieques Island, Puerto Rico: Proceedings of the First Caribbean Islands Water Resources Congress, St. Thomas, U.S. Virgin Islands, July 26-27, 1984, p. 298-311.

Torres-González, Sigfredo, 1989, Reconnaissance of the ground-water resources of Vieques Island, Puerto Rico: U.S. Geological Survey WaterResources Investigations Report 86-4100, 37 p.

Vaughan, T.W., 1920, The ground-water resources of the West Indian Islands, St. John, St. Thomas, Culebra and Vieques, and of the eastern end of Puerto Rico: U.S. Geological Survey Open-File Report. 


\section{Villalba}

Figueroa-Alamo, Carlos, 1991, Sedimentation survey of Lago Toa Vaca, Puerto Rico, July 1985: U.S. Geological Survey Open-File Report 90-199, 9 p.

\section{Yabucoa}

Anders, R.B., 1971, Electric analog model study of water in the Yabucoa Valley, Puerto Rico (Phase-1, Collecting preliminary data and assembling available data): U.S. Geological Survey Open-File Report 71-5, 47 p.

Collar, P.D., Troester, J.W., Deike, R.G., and Robinson, P.D., 1990, Iron and manganese in alluvial ground water, Yabucoa, Puerto Rico: Proceedings of the Interamerican Association of Sanitary and Environmental Engineers Annual Meeting, v. 3, p. 708-732.

Fields, F.K., 1971, Floods in the Yabucoa area, Puerto Rico: U.S. Geological Survey Hydrologic Investigations Atlas HA-382, 1 sheet.

Richards, R.T., Troester, J.W., 1992, Using surface geophysical techniques to map the saline-freshwater interface and the depth to bedrock in the Valle de Yabucoa alluvial aquifer, Puerto Rico [Abstract]: Proceedings of the 17th Symposium of Natural Resources, San Juan, Puerto Rico, November 1991.

Robison, T.M., and Anders, R.B., 1973, Electric analog model study of the alluvial aquifer in the Yabucoa Valley, Puerto Rico (Phase 2--The planning, construction, and use of the model): U.S. Geological Survey Open-File Report 73-242, 47 p.

Troester, J.W., Collar, P.D., Robinson, P.D.*, and Deike, R.G., 1990, Geochemical processes controlling manganese and iron concentrations in the ground water of the Valle de Yabucoa alluvial aquifer, Puerto Rico [Abstract]: EOS, Transactions, American Geophysical Union, April 24, 1990 , v. 71 , no. 17 , p. 506.

Troester, J.W., Deike, R.G., Robinson, P.D.*, and Collar, P.D., 1990, Petrographic analyses and geochemical modeling of aquequs/solid phase reactions in the Valle de Yabucoa alluvial aquifer, Puerto Rico [Abstract]: The Geological Society of America, Abstracts with Programs, p. A295.

\section{Yauco}

Crooks, J.W., Grossman, I.G., and Bogart, D.B., 1968, Water resources of the Guayanilla-Yauco area, Puerto Rico: U.S. Geological Survey Water-Resources Bulletin 5, 55 p., 7 pls.

Fields, F.K., 1971, Floods in the Guayanilla-Yauco area, Puerto Rico: U.S. Geological Survey Hydrologic Investigations Atlas HA-414, 1 sheet.

Graves, R.P., 1991, Ground-water resources in Lajas Valley, Puerto Rico: U.S. Geological Survey Water-Resources Investigations Report $89-4182,55 \mathrm{p}$.

Grossman, I.G., 1962, Stratigraphy and hydrology of the Juana Díaz Formation in the Yauco area, Puerto Rico: in Short Papers in Geology, Hydrology, and Topography, Articles 120-179, U.S. Geological Survey Professional Paper 450-D, Article 137, p. 62-63.

Johnson, K.G., 1974, Floods in eastern Lajas Valley and the lower Río Loco basin, southwestern Puerto Rico: U.S. Geological Survey Hydrologic Investigations Atlas HA-532, 1 sheet.

Johnson, K.G., 1982, Flood of September 16, 1975, in the Yauco Valley, Puerto Rico: U.S. Geological Survey Open-File Report 81-331, 13 p.

Quiñones-Aponte, Vicente, 1986, Simulation of ground-water flow in the Río Yauco alluvial valley, Yauco, Puerto Rico: U.S. Geological Survey Water-Resources Investigations Report 85-4179, $32 \mathrm{p}$ 


\section{PUBLICATIONS BY ISLAND IN THE U.S. VIRGIN ISLANDS}

St. Croix, St. John, and St. Thomas 


\section{PUBLICATIONS BY ISLANDS IN THE U.S. VIRGIN ISLANDS}

\section{U.S. Virgin Islands}

Colón-Dieppa, Eloy, Díaz, P.L., and García, René, 1987, Water resources data Puerto Rico and the U.S. Virgin Islands, Water Year 1985: U.S. Geological Survey Water-Data Report PR-85-1, 400 p.

Colón-Dieppa, Eloy, Torres-Sierra, Heriberto, and Ortíz, Jorge, 1991, U.S. Virgin Islands floods and droughts - National Water Summary 1988-89: U.S. Geological Survey Water-Supply Paper 2375, p. 521-526.

Curtis, R.E., Jr., Guzmán-Ríos, Senén, and Díaz, P.L., 1984, Water resources data Puerto Rico and the U.S. Virgin Islands, Water Year 1983: U.S. Geological Survey Water-Data Report PR-83-1, 302 p.

Curtis, R.E., Jr., Guzmán-Ríos, Senén, and Díaz, P.L., 1985, Water resources data Puerto Rico and the U.S. Virgin Islands, Water Year 1984: U.S. Geological Survey Water-Data Report PR-84-1, 374 p.

Curtis, R.E., Jr., Aquino, Zaida, Díaz, P.L., and García, René, 1988, Water resources data Puerto Rico and the U.S. Virgin Islands, Water Year 1986: U.S. Geological Survey Water-Data Report PR-86-1, 362 p.

Curtis, R.E., Jr., Aquino, Zaida, Díaz, P.L., and Vachier, Ricardo, 1989, Water resources data Puerto Rico and the U.S. Virgin Islands, Water Year 1987: U.S. Geological Survey Water-Data Report PR-87-1, 356 p.

Curtis, R.E., Jr., Aquino, Zaida, Díaz, P.L., and Vachier, Ricardo, 1989, Water resources data for Puerto Rico and the U.S. Virgin Islands, Water Year 1988: U.S. Geological Survey Water-Data Report PR-88-1, 460 p.

Curtis, R.E., Jr., Aquino, Zaida, Díaz, P.L., and Vachier, Ricardo, 1990, Water resources data for Puerto Rico and the U.S. Virgin Islands, Water Year 1989: U.S. Geological Survey Water-Data Report PR-89-1, 419 p.

Curtis, R.E., Jr., Aquino, Zaida, Díaz, P.L., and Vachier, Ricardo, 1991, Water resources data for Puerto Rico and the U.S. Virgin Islands, Water Year 1990: U.S. Geological Survey Water-Data Report PR-90-1, 514 p.

García, René, and Canoy, Michael, 1984, Reconnaissance of ground-water quality in the Virgin Islands, July 1984: U.S. Geological Survey Open-File Data Report 84-807, 1 sheet.

Gómez-Gómez, Fernando, Quiñones-Márquez, Ferdinand, and Zack, A.L., 1984, U.S. Virgin Islands ground-water resources - National Water Summary 1984: U.S. Geological Survey Water-Supply Paper 2275, p. 409-413.

Jordan, D.G., 1972, Land-use effect on the water regimen of the U.S. Virgin Islands: in Geological Survey Research 1972, Chap. D, U.S. Geological Survey Professional Paper 800-D, p. 211-216.

McGuinness, C.L., 1953, Summary of the water resources of the Virgin Islands: U.S. Geological Survey Open-File Report, 8 p.

Quiñones, Ferdinand, and Alicea, José, 1981, Water resources investigations in Puerto Rico and the U.S. Virgin Islands - Programs and activities of the U.S. Geological Survey, Water Resources Division, Caribbean District: U.S. Geological Survey Open-File Report, 69 p.

Quiñones, Ferdinand, and Alicea, José, 1983, Water resources investigations in Puerto Rico and the U.S. Virgin Islands - Programs and activities of the U.S. Geological Survey, Water Resources Division, Caribbean District: U.S. Geological Survey Open-File Report, 28 p.

Quiñones, Ferdinand, and Alicea, José, 1984, Water resources investigations in Puerto Rico and the U.S. Virgin Islands - Programs and activities of the U.S. Geological Survey, Water Resources Division, Caribbean District: U.S. Geological Survey Open-File Report, 41 p.

Quiñones, Ferdinand, and López, Marisol, 1984, Publications of the U.S. Geological Survey, Water Resources Division for Puerto Rico and the U.S. Virgin Islands, 1946-1984: U.S. Geological Survey Open-File Data Report 84-229, 32 p.

Quiñones, Ferdinand, and Rivera, Elba, 1985, Publications of the U.S. Geological Survey, Water Resources Division for Puerto Rico and the U.S. Virgin Islands, 1946-1985: U.S. Geological Survey Open-File Data Report 85-414, 21 p.

Quiñones-Márquez, Ferdinand, and Peña-Cruz, Gilberto, 1985, Water resources investigations in Puerto Rico and the U.S. Virgin Islands Programs and activities of the U.S. Geological Survey, Water Resources Division, Caribbean District 1984-1985: U.S. Geological Survey Open-File Report 85-556, 43 p.

Reid, Ken, 1991, Cost-effectiveness of the stream-gaging program in Puerto Rico and the U.S. Virgin Islands: U.S. Geological Survey WaterResources Investigations Report 90-4088, 32 p.

Robison, T.M., and others, 1972, Water records of the U.S. Virgin Islands, 1962-69: U.S. Geological Survey Water-Data Report, 163 p. 


\section{U.S. Virgin Islands--Continued}

Santiago-Rivera, Luis, and Colón-Dieppa, Eloy, 1986, U.S. Virgin Islands surface-water resources - National Water Summary 1985: U.S. Geological Survey Water-Supply Paper 2300, p. 447-452.

Schuck-Kolben, R.E., and Kaufman, Lionel, 1991, Storm-surge flooding by Hurricane Hugo on the U.S. Virgin Islands, Puerto Rico, and South Carolina, September 1989 - National Water Summary 1988-89: U.S. Geological Survey Water-Supply Paper 2375, p. 59-64.

Stevens, K.E., Gómez-Gómez, Fernando, and Ahcea, José, 1981, Water wells in the U.S. Virgin Islands, Part 1, St. Thomas: U.S. Geological Survey Open-File Report 82-82, 112 p.

Troester, J.W., 1988, U.S. Geological Survey ground-water studies in the U.S. Virgin Islands: U.S. Geological Survey Water Fact Sheet, OpenFile Report 88-163, 2 p.

U.S. Geological Survey, 1979, Water-resources investigations in Puerto Rico and the U.S. Virgin Islands, 1978: U.S. Geological Survey Folder.

U.S. Geological Survey, 1983, Puerto Rico and the U.S. Virgin Islands water issues: National Water Summary 1983 - Hydrologic Events and Issues, U.S. Geological Survey Water-Supply Paper 2250, p. 200-202.

Veve, T.D., and Troester, J.W., 1990, Water-resources investigations in Puerto Rico and the U.S. Virgin Islands, 1986-1988: U.S. Geologic Survey Open-File Report 90-122, 39 p.

Ward, P.E., and Jordan, D.G., 1963, Water resources of the Virgin Islands, A preliminary appraisal, 1963: U.S. Geological Survey Open-File Report, 44 p.

Zack, A.L., Rodríguez-Alonso, Teresita, and Román-Más, Angel, 1987, U.S. Virgin Islands ground-water quality - National Water Summary: U.S. Geological Survey Water-Supply Paper 2325, p. 489-492.

\section{St. Croix}

Cederstrom, D.J., 1950, Geology and ground-water resources of St. Croix, Virgin Islands: U.S. Geological Survey Water-Supply Paper 1067, 117 p., 1 pl.

Colón-Ramos, H.M., 1983, Ground-water records for St. Croix, U.S. Virgin Islands, 1969-1973: U.S. Geological Survey Open-File Data Report $83-546,28 \mathrm{p}$.

Haire, W.J., and Johnson, K.G., 1978, Floods of November 11-13, 1974, in St. Croix, U.S. Virgin Islands: U.S. Geological Survey WaterResources Investigations Report 77-136, 11 sheets.

Hendrickson, G.E., 1962, Development of the ground-water resources of St. Croix, Virgin Islands: U.S. Geological Survey Open-File Report, $84 \mathrm{p}$.

Hendrickson, G.E., 1963, Ground water for public supply in St. Croix, Virgin Islands: U.S. Geological Survey Water-Supply Paper 1663-D, 27 p.

Johnson, K.G., Carrasquillo, R.A., and González, Ralph, 1982, Flood of October 8, 1977, in St. Croix, U.S. Virgin Islands: U.S. Geological Survey Open-File Report 82-262, 21 p., 3 pls.

Jordan, D.G., 1975, A survey of the water resources of St. Croix, Virgin Islands: U.S. Geological Survey Open-File Report 73-137, 51 p.

Robison, T.M., 1972, Ground water in central St. Croix, U.S. Virgin Islands: U.S. Geological Survey Open-File Report, 18 p.

Torres-González, Sigfredo, 1991, Steady-state simulation of ground-water flow conditions in the Kingshill aquifer, St. Croix, U.S. Virgin Islands, July 1987: in Gómez-Gómez, Fernando, Quiñones-Aponte, Vicente, and Johnson, A.I., eds., Aquifers of the Caribbean Islands, Proceedings of the International Symposium on Tropical Hydrology, San Juan, Puerto Rico, July 23-27, 1990, AWRA Monograph Series no. 15, p. 93-108.

Torres-González, Sigfredo, and Rodríguez-del-Río, Félix, 1990, Potentiometric surface of the Kingshill aquifer and hydrologic conditions, St. Croix, U.S. Virgin Islands, July 1987: U.S. Geological Survey Water-Resources Investigations Report 89-4085, 1 sheet.

Torres-Sierra, Heriberto, 1986, Estimated water use in St. Croix, U.S. Virgin Islands, 1983-1985: in Quiñones, Ferdinand, Sánchez, A.V., and Smith, H.H., eds., Proceedings of the Third Caribbean Islands Water-Resources Congress, U.S. Virgin Islands, July 22-25, 1986, Puerto Rico Water Resources Association, p. 7-11.

Torres-Sierra, Heriberto, 1987, Estimated water use in St. Croix, U.S. Virgin Islands, October 1983 - September 1985: U.S. Geological Survey Open-File Data Report 86-537, 1 sheet. 


\section{St. John}

Cosner, O.J., 1972, Water in St. John, U.S. Virgin Islands: U.S. Geological Survey Open-File Report 72-78, 46 p.

Curtis, R.E., Jr., 1984, Floods of April 18, 1983 on St. Thomas and St. John, U.S. Virgin Islands: U.S. Geological Survey Water-Resources Investigations Report 84-4184, 1 sheet.

Curtis, R.E., Jr., 1985, Floods of April 18, 1983 on St. Thomas and St. John, U.S. Virgin Islands: Proceedings of the Tropical Hydrology and Second Caribbean Islands Water-Resources Congress, May 5-8, 1985, American Water Resources Association, Technical Publication Series TPS-85-1, p. 90-95.

Vaughan, T.W., 1920, The ground-water resources of the West Indian Islands, St. John, St. Thomas, Culebra and Vieques, and of the eastern end of Puerto Rico: U.S. Geological Survey Open-File Report.

\section{St. Thomas}

Curtis, R.E., Jr., 1984, Floods of April 18, 1983 on St. Thomas and St. John, U.S. Virgin Islands: U.S. Geological Survey Water-Resources Investigations Report 84-4184, 1 sheet.

Curtis, R.E., Jr., 1985, Floods of April 18, 1983 on St. Thomas and St. John, U.S. Virgin Islands: Proceedings of the Tropical Hydrology and Second Caribbean Islands Water-Resources Congress, May 5-8, 1985, American Water Resources Association, Technical Publication Series TPS-85-1, p. 90-95.

Graves, R.P., and Gonzalez, Ralph, 1988, Potentiometric surface of the Turpentine Run basin aquifer in the Tutu area, eastern St. Thomas, U.S. Virgin Islands, September 11, 1987: U.S. Geological Survey Water-Resources Investigations Report 88-4131, 1 sheet.

Grossman, I.G., 1959, Ground-water data from St. Thomas, Virgin Islands: U.S. Geological Survey Open-File Report, 35 p., 5 pls.

Grossman, I.G., 1962, Chemical quality of ground water in St. Thomas, Virgin Islands: in Short Papers in Geology, Hydrology, and Topography, Articles 1-59, U.S. Geological Survey Professional Paper 450-B, Article 55, p. 131-133.

Haire, W.J., and Johnson, K.G., 1973, Floods in and near the Charlotte Amalie area, St. Thomas, U.S. Virgin Islands: U.S. Geological Survey Hydrologic Investigations Map Series no. 3, 4 sheets.

Haire, W.J., and Johnson, K.G., 1977, Floods of November 12, 1974, in the Charlotte Amalie area, St. Thomas, U.S. Virgin Islands: U.S. Geological Survey Water-Resources Investigations Report 76-91, 3 sheets.

Jordan, D.G., and Cosner, O.J., 1973, A survey of the water resources of St. Thomas, Virgin Islands: U.S. Geological Survey Open-File Report 72-201, $55 \mathrm{p}$.

Jordan, D.G., and Fisher, D.W., 1977, Relation of bulk precipitation and evaporation to water quality and water resources, St. Thomas, Virgin Islands: U.S. Geological Survey Water-Supply Paper 1663-I, 30 p.

Robison, T.M., 1971, Earthquake-accelerated decline of water level in an observation well in St. Thomas, Virgin Islands: U.S. Geological Survey Professional Paper 750-B, p. 252-253.

Torres-Sierra, Heriberto, and Dacosta, Rafael, 1984, Estimated water use in St. Thomas, U.S. Virgin Islands, July 1983 - June 1984: U.S. Geological Survey Open-File Data Report 84-721, 1 sheet.

Vaughan, T.W., 1920, The ground-water resources of the West Indian Islands, St. John, St. Thomas, Culebra and Vieques, and of the eastern end of Puerto Rico: U.S. Geological Survey Open-File Report. 


\title{
PUBLICATIONS BY DISCIPLINE
}

The publications in the 11 categories under this heading are listed alphabetically by senior author.

\author{
Multidisciplinary \\ (Ground Water, Surface Water, and Water Quality) \\ Climate and Geomorphology \\ Floods \\ Geology \\ Ground Water \\ Ground-Water Level \\ Ground-Water Modeling \\ Sediment \\ Surface Water \\ Water Quality \\ Water Use
}




\section{PUBLICATIONS BY DISCIPLINE}

\section{Ground Water, Surface Water, and Water Quality}

Arnow, Ted, and Bogart, D.B., 1959, Water problems of Puerto Rico and a program of water-resources investigations: Transactions of the Second Caribbean Geological Conference, January 4-9, 1959, Mayagüez, Puerto Rico, p. 120-129.

Bogart, D.B., Arnow, Ted, and Crooks, J.W., 1960, Water problems of Puerto Rico and a program of water-resources investigations: U.S. Geological Survey Water-Resources Bulletin 1, 40 p.

Bogart, D.B., Arnow, Ted, and Crooks, J.W., 1964, Water resources of Puerto Rico - A progress report: U.S. Geological Survey WaterResources Bulletin 4, $120 \mathrm{p}$.

Colón-Dieppa, Eloy, and Mansue, L.J., 1976, Water resources of the proposed copper mining area, Puerto Rico, 1958-74 (2 Parts): U.S. Geological Survey Open-File Report 76-1 and 76-2, 414 p.

Colón-Dieppa, Eloy, Díaz, P.L., and García, René, 1987, Water resources data Puerto Rico and the U.S. Virgin Islands, Water Year 1985: U.S. Geological Survey Water-Data Report PR-85-1, 400 p.

Cosner, O.J., 1972, Water in St. John. U.S. Virgin Islands: U.S. Geological Survey Open-File Report 72-78, 46 p.

Crooks, J.W., Grossman, 1.G., and Bogart, D.B., 1968, Water resources of the Guayanilla-Yauco area, Puerto Rico: U.S. Geological Survey Water-Resources Bulletin 5, 55 p., 7 pls.

Curtis, R.E., Jr., Guzmán-Ríos, Senén, and Díaz, P.L., 1984, Water resources data Puerto Rico and the U.S. Virgin Islands, Water Year 1983: U.S. Geological Survey Water-Data Report PR-83-1, 302 p.

Curtis, R.E.. Jr., Guzmán-Ríos, Senén, and Díaz, P.L., 1985, Water resources data Puerto Rico and the U.S. Virgin Islands, Water Year 1984: U.S. Geological Survey Water-Data Report PR-84-1, 374 p.

Curtis, R.E., Jr., McKinley P.W., and Colón-Ramos, H.M., 1983, Water resources data Puerto Rico, Water Years 1981-82: U.S. Geological Survey Water-Data Report PR-81-82-1, 414 p.

Curtis, R.E., Jr., A quino, Zaida, Díaz, P.L., and García, René, 1988, Water resources data Puerto Rico and the U.S. Virgin Islands, Water Year 1986: U.S. Geological Survey Water-Data Report PR-86-1, 362 p.

Curtis, R.E., Jr., Aquino, Zaida, Díaz, P.L., and Vachier, Ricardo, 1989, Water resources data Puerto Rico and the U.S. Virgin Islands, Water Year 1987: U.S. Geological Survey Water-Data Report PR-87-1, 356 p.

Curtis, R.E., Jr., Aquino, Zaida, Díaz, P.L., and Vachier, Ricardo, 1989, Water resources data for Puerto Rico and the U.S. Virgin Islands, Water Year 1988: U.S. Geological Survey Water-Data Report PR-88-1, 460 p.

Curtis, R.E., Jr., Aquino, Zaida, Díaz, P.L., and Vachier, Ricardo, 1990, Water resources data for Puerto Rico and the U.S. Virgin Islands, Water Year 1989: U.S. Geological Survey Water-Data Report PR-89-1, 419 p.

Curtis, R.E., Jr., Aquino, Zaida, Díaz, P.L., and Vachier, Ricardo, 1991, Water resources data for Puerto Rico and the U.S. Virgin Islands, Water Year 1990: U.S. Geological Survey Water-Data Report PR-90-1, 514 p.

Díaz, J.R., 1973, Chemical quality of water in Caño Tiburones, Puerto Rico: A reconnaissance study carried out in 1967: U.S. Geological Survey Open-File Report Map Series no. 2, 2 pls.

Durfor, C.N., and Becker, Edith, 1964, Chemical quality of public water supplies of the United States and Puerto Rico, 1962: U.S. Geological Survey Hydrologic Investigations Atlas HA-200, 1 sheet.

Ellins, K.K., Román-Más, Angel, and Lee, R.N., 1986, Estimating ground water influx to a portion of the Río Grande de Manatí River basin in Puerto Rico through the measurement of ${ }^{222} \mathrm{Rn}$ : in Quiñones, Ferdinand, Sánchez, A.V., and Smith, H.H., eds., Proceedings of the Third Caribbean Islands Water-Resources Congress, U.S. Virgin Islands, July 22-25, 1986, Puerto Rico Water Resources Association, p. 27.

Giusti, E.V., 1968. Water resources of the Juana Díaz area, Puerto Rico - A preliminary appraisal, 1966: U.S. Geological Survey WaterResources Bulletin 8, 43 p.

Giusti, E.V., and Bennett, G.D., 1976, Water resources of the north coast limestone area, Puerto Rico: U.S. Geological Survey Water-Resources Investigations Report $75-42,42 \mathrm{p}$

Gómez-Gómez, Fernando, 1984, Water resources of the lower Río Grande de Manatí Valley: U.S. Geological Survey Water-Resources Investigations Report 83-4199, 42 p. 


\section{Ground Water, Surface Water, and Water Quality--Continued}

Gómez-Gómez, Fernando, 1986, Caribbean Islands Regional Aquifer-System Study - Phase 1, Regional Aquifer-System Study projects started in 1984: in Ren Jen Sun, ed., Summary of Projects 1978-84: U.S. Geological Survey Circular 1002, p. $234-241$.

Gómez-Gómez, Fernando, 1987, Planning report for the Caribbean Islands Regional Aquifer-System Analysis project: U.S. Geological Survey Water-Resources Investigations Report 86-4074, 50 p., 3 pls.

Gómez-G6́mez, Fernando, 1990, Hydrochemistry of the South Coastal Plain Aquifer System of Puerto Rico and its relation to surface-water recharge: in Gómez-Gómez, Fernando, Quiñones-Aponte, Vicente, and Johnson, A.I., eds., Aquifers of the Caribbean Islands, Proceedings of the International Symposium on Tropical Hydrology, San Juan, Puerto Rico, July 23-27, 1990, AWRA Monograph Series no. 15, p. 57-75.

Graves, R.P., 1989, Water resources of the Humacao-Naguabo area, eastern Puerto Rico: U.S. Geological Survey Water-Resources Investigations Report 87-4088, 69 p.

Graves, R.P., 1991, Ground-water resources in Lajas Valley, Puerto Rico: U.S. Geological Survey Water-Resources Investigations Report $89-4182,55$ p.

Graves, R.P., 1992, Geohydrology of the Aguirre and Pozo Hondo areas, southern Puerto Rico: U.S. Geological Survey Water-Resources Investigations Report 91-4124, 43 p.

Grossman, I.G., Bogart, D.B., Crooks, J.W., and Díaz, J.R., 1972, Water resources of the Tallaboa Valley, Puerto Rico: U.S. Geological Survey Water-Resources Bulletin 7,115 p.

Jordan, D.G., 1970, Water and copper-mine tailings in karst terrane of Río Tanamá basin, Puerto Rico: U.S. Geological Survey Open-File Report $71-163,24 \mathrm{p}$.

Jordan, D.G., 1975, A survey of the water resources of St. Croix, Virgin Islands: U.S. Geological Survey Open-File Report 73-137, 51 p.

Jordan, D.G., and Cosner, O.J., 1973, A survey of the water resources of St. Thomas, Virgin Islands: U.S. Geological Survey Open-File Report 72-201, $55 \mathrm{p}$.

Kipple, F.P., and others, 1968, Water records of Puerto Rico, 1958-63: U.S. Geological Survey Water-Data Report, 353 p.

Lohr, E.W., 1957, Chemical character of public water supplies of the larger cities in Alaska, Hawaii, and Puerto Rico, 1954: U.S. Geological Survey Water-Supply Paper 1460-A, 39 p., 1 pl.

McClymonds, N.E., 1967, Water resources of the Guánica area, Puerto Rico - A preliminary appraisal, 1963: U.S. Geological Survey WaterResources Bulletin 6, 43 p.

McClymonds, N.E., 1972, Water resources of the Ponce area, Puerto Rico: U.S. Geological Survey Water-Resources Bulletin 14, 26 p.

McClymonds, N.E., and Díaz, J.R., 1972, Water resources of the Jobos area, Puerto Rico - A preliminary appraisal, 1962: U.S. Geological Survey Water-Resources Bulletin 13, 32 p.

McClymonds, N.E., and Ward, P.E., 1966, Hydrologic characteristics of the alluvial fan near Salinas, Puerto Rico: in Geological Survey Research 1966, Chap. C, U.S. Geological Survey Professional Paper 550-C, p. 231-234.

McCoy, J.H., 1978, Summary of the water resources of Puerto Rico: U.S. Geological Survey Open-File Report 78-971, 24 p.

McGuinness, C.L., 1953, Summary of the water resources of the Virgin Islands: U.S. Geological Survey Open-File Report, 8 p.

Quiñones, Ferdinand, and Alicea, José, 1981, Water resources investigations in Puerto Rico and the U.S. Virgin Islands - Programs and activities of the U.S. Geological Survey, Water Resources Division, Caribbean District: U.S. Geological Survey Open-File Report, 69 p.

Quiñones, Ferdinand, and Alicea, José, 1983, Water resources investigations in Puerto Rico and the U.S. Virgin Islands - Programs and activities of the U.S. Geological Survey, Water Resources Division, Caribbean District: U.S. Geological Survey Open-File Report, 28 p.

Quiñones, Ferdinand, and Alicea, José, 1984, Water resources investigations in Puerto Rico and the U.S. Virgin Islands - Programs and activities of the U.S. Geological Survey, Water Resources Division, Caribbean District: U.S. Geological Survey Open-File Report, 41 p.

Quiñones, Ferdinand, and López, Marisol, 1984, Publications of the U.S. Geological Survey, Water Resources Division for Puerto Rico and the U.S. Virgin Islands, 1946-1984: U.S. Geological Survey Open-File Data Report 84-229, 32 p.

Quiñones, Ferdinand, and Rivera, Elba, 1985, Publications of the U.S. Geological Survey, Water Resources Division for Puerto Rico and the U.S. Virgin Islands, 1946-1985: U.S. Geological Survey Open-File Data Report 85-414, 21 p.

Quiñones-Aponte, Vicente, 1986, Water resources of the lower Río Grande de Arecibo alluvial valley, Puerto Rico: U.S. Geological Survey Water-Resources Investigations Report 85-4160, 38 p., 1 pl. 


\section{Ground Water, Surface Water, and Water Quality--Continued}

Quiñones-Aponte, Vicente, 1989, Hydrogeologic characteristics of the lower Río Grande de Arecibo alluvial valley: Proceedings of the 13th Natural Resources Symposium, San Juan, Puerto Rico, February 26, 1987, Puerto Rico Department of Natural Resources, p. $41-59$.

Quiñones-Márquez, Ferdinand, and Peña-Cruz, Gilberto, 1985, Water resources investigations in Puerto Rico and the U.S. Virgin Islands Programs and Activities of the U.S. Geological Survey, Water Resources Division, Caribbean District 1984-1985: U.S. Geological Survey Open-File Report 85-556, 43 p.

Quiñones-Márquez, Ferdinand, López, M.A., and Latkovich, V.J., 1976, Water records of the Río Piedras basin, Puerto Rico, 1971-74: U.S. Geological Survey Open-File Report 76-3, 111 p.

Rickler, J.G., and others, 1970, Water records of Puerto Rico, 1964-67, Volume 1, north and northeast slopes: U.S. Geological Survey WaterData Report 71-238, 265 p.

Rickler, J.G., and others, 1970, Water records of Puerto Rico, 1964-67, Volume 2, south and west slopes: U.S. Geological Survey Water-Data Report, 308 p.

Robison, T.M., and others, 1972, Water records of the U.S. Virgin Islands, 1962-69: U.S. Geological Survey Water-Data Report, 163 p.

Román-Más, Angel, 1986, Role of blanket deposits on the hydrology and water chemistry of the limestone water-table aquifer within the north coast of Puerto Rico through interpretation of geochemical data: in Quiñones, Ferdinand, Sánchez, A.V., and Smith, H.H., eds., Proceedings of the Third Caribbean Islands Water-Resources Congress, U.S. Virgin Islands, July 22-25, 1986, Puerto Rico Water Resources Association, p. 33.

Torres-González, Arturo, and Díaz, J.R., 1984, Water resources of the Sabana Seca to Vega Baja area, Puerto Rico: U.S. Geological Survey Water-Resources Investigations Report 82-4115, 53 p.

Torres-González, Sigfredo, 1984, Water-resources investigations of Vieques Island, Puerto Rico: Proceedings of the First Caribbean Islands Water-Resources Congress, St. Thomas, U.S. Virgin Islands, July 26-27, 1984, p. 298-311.

U.S. Geological Survey, 1978, Water resources data for Puerto Rico, Surface and quality-of-water records, Water Years 1975-76, Ground water records, Water Years 1973-76: U.S. Geological Survey Water-Data Report PR-76-1, 366 p.

U.S. Geological Survey, 1979, Water-resources investigations in Puerto Rico and the U.S. Virgin Islands, 1978: U.S. Geological Survey Folder.

U.S. Geological Survey, 1981, Water resources data for Puerto Rico, Water Year 1978: U.S. Geological Survey Water-Data Report PR-78-1, 255 p.

U.S. Geological Survey, 1982, Water resources data for Puerto Rico, Water Years 1979-80: U.S. Geological Survey Water-Data Report PR-79-80, $408 \mathrm{p}$.

U.S. Geological Survey, 1983, Puerto Rico and the U.S. Virgin Islands water issues: National Water Summary 1983 - Hydrologic Events and Issues, U.S. Geological Survey Water-Supply Paper 2250, p. 200-202.

Vaughan, T.W., 1920, The ground-water resources of the West Indian Islands, St. John, St. Thomas, Culebra and Vieques, and of the eastern end of Puerto Rico: U.S. Geological Survey Open-File Report.

Veve, T.D., and Troester, J.W., 1990, Water-resources investigations in Puerto Rico and the U.S. Virgin Islands, 1986-1988: U.S. Geologic Survey Open-File Report 90-122, 39 p.

Ward, P.E., and Jordan, D.G., 1963, Water resources of the Virgin Islands, A preliminary appraisal, 1963: U.S. Geological Survey Open-File Report, 44 p.

Wilson, H.M., 1899, Water resources of Puerto Rico: U.S. Geological Survey Water-Supply Paper 32.

\section{Climate and Geomorphology}

Giusti, E.V., and López, M.A., 1967, Climate and streamflow of Puerto Rico: Caribbean Journal of Science, September - December, 1967, v. 7, no. $3-4$, p. $87-93$.

Jordan, D.G., and Fisher, D.W., 1977, Relation of bulk precipitation and evaporation to water quality and water resources, St. Thomas, Virgin Islands: U.S. Geological Survey Water-Supply Paper 1663-I, 30 p.

Larsen, M.C., 1990, Landslides and pore pressure responses associated with Hurricane Hugo, September 1989, eastern Puerto Rico [Abstract]: The Geological Society of America, Abstracts with Programs, v. 22, no. 7., p. A331. 


\section{Climate and Geomorphology--Continued}

Larsen, M.C., 1990, Landslides caused by the intense precipitation of Hurricane Hugo in El Yunque and surrounding areas: Boletín Oficial de la Sociedad de Historia Natural de Puerto Rico, v. 24, no. 12, p. 8.

Larsen, M.C., 1990, Landslides caused by the intense precipitation of Hurricane Hugo, September 1989, eastern Puerto Rico [Abstract]: EOS, Transactions, American Geophysical Union, v. 71, no. 6., p. 257.

Larsen, M.C., 1991, Mass wasting disturbance and denudation in a humid-tropical montane forest, Puerto Rico [Abstract]: The Geological Society of America, Abstracts with Programs, v. 23, no. 5, p. A256.

Larsen, M.C., and Simon, Andrew, 1990, Landslide processes in saprolitic soils of a tropical rain forest, Puerto Rico: in Larue, D.K., and Draper, G., eds., Transactions of the 12th Caribbean Geological Conference, St. Croix, U.S. Virgin Islands, Miami Geological Society, p. $217-222$.

Larsen, M.C., and Simon, Andrew, 1992, A rainfall intensity-duration threshold relation for landslide occurrence in the humid-tropical environment of Puerto Rico [Abstract]: The Geological Society of America, Abstracts with Programs, v. 24, no. 7, p. A166.

Larsen, M.C., and Torres-Sánchez, A.J., 1990, Rainfall-soil moisture relations in landslide-prone areas of a tropical rain forest, Puerto Rico: in Krishna, J.H., Quiñones-Aponte, Vicente, Gómez-Gómez, Fernando, and Morris, G.L., eds., Tropical Hydrology and Caribbean Water Resources, Proceedings of the International Symposium on Tropical Hydrology, San Juan, Puerto Rico, July 23-27, 1990, AWRA TPS-90-2, p. 121-129.

Larsen, M.C., and Torres-Sánchez, A.J., 1992, Landslides triggered by Hurricane Hugo in eastern Puerto Rico, September 1989: Caribbean Journal of Science, v. 28, no. 3-4, p. 113-125.

Monroe, W.H., 1979, Map showing landslides and areas of susceptibility to landsliding in Puerto Rico: U.S. Geological Survey Miscellaneous Investigations Map Series, 1 sheet.

Quiñones-Márquez, Ferdinand, 1975, Chemical composition of rainfall at selected sites in Puerto Rico: U.S. Geological Survey Open-File Report 75-364, 17 p.

Quiñones-Márquez, Ferdinand, 1978, Selected chemical properties of rainfall in the Río Piedras basin, Puerto Rico: U.S. Geological Survey Open-File Report 78-159, 14 p.

Román-Más, Angel, and Green, Bruce, 1987, Climatological data for the rice-growing areas along the north coast of Puerto Rico: U.S. Geological Survey Open-File Data Report 86-53, 90 p.

Scatena, F.N., and Larsen, M.C., 1991, Physical aspects of Hurricane Hugo in Puerto Rico: Biotropica, v. 23, no. 4A, p. 317-323.

Schuck-Kolben, R.E., and Kaufman, Lionel, 1991, Storm-surge flooding by Hurricane Hugo on the U.S. Virgin Islands, Puerto Rico, and South Carolina, September 1989 - National Water Summary 1988-89: U.S. Geological Survey Water-Supply Paper 2375, p. 59-64.

Troester, J.W., 1992, Wind as a hydrogeologic agent and cultural factor in the Lesser Antilles [Abstract]: The Geologic Society of America, Abstracts with Programs, v. 24, no. 7, p. A68.

Yuan, Daoxian, and Troester, J.W., 1990, Evidence of climatic control on hydrogeologic processes in the karst terranes of Central China and Puerto Rico [Abstract]: Proceedings of the International Symposium and Field Seminar on Hydrogeological Processes in Karst Terranes, Antalya, Turkey, October 7-17, 1990, p. 120-121.

\section{Floods}

Barnes, H.H., Jr., and Bogart, D.B., 1961, Floods of September 6, 1960, in eastern Puerto Rico: U.S. Geological Survey Circular 451, 13 p.

Colón-Dieppa, Eloy, and Torres-Sierra, Heriberto, 1991, Puerto Rico floods and droughts - National Water Summary 1988-89: U.S. Geological Survey Water-Supply Paper 2375, p. 475-482.

Colón-Dieppa, Eloy, Torres-Sierra, Heriberto, and Ortíz, Jorge, 1991, U.S. Virgin Islands floods and droughts - National Water Summary 1988-89: U.S. Geological Survey Water-Supply Paper 2375, p. 521-526.

Curtis, R.E., Jr., 1984, Floods of April 18, 1983 on St. Thomas and St. John, U.S. Virgin Islands: U.S. Geological Survey Water-Resources Investigations Report 84-4184, 1 sheet.

Curtis, R.E., Jr., 1985, Floods of April 18, 1983 on St. Thomas and St. John, U.S. Virgin Islands: Proceedings of the Tropical Hydrology and Second Caribbean Islands Water-Resources Congress, May 5-8, 1985, American Water Resources Association, Technical Publication Series TPS-85-1, p. 90-95.

Fields, F.K., 1971, Floods in the Añasco area, Puerto Rico: U.S. Geological Survey Hydrologic Investigations Atlas HA-375, 1 sheet. 


\section{Floods--Continued}

Fields, F.K., 1971, Floods in the Guayanilla-Yauco area, Puerto Rico: U.S. Geological Survey Hydrologic Investigations Atlas HA-414, 1 sheet.

Fields, F.K., 1971, Floods in the Yabucoa area, Puerto Rico: U.S. Geological Survey Hydrologic Investigations Atlas HA-382, 1 sheet.

Fields, F.K., 1972, Floods at Caguas, Gurabo, Juncos, and San Lorenzo, Puerto Rico: U.S. Geological Survey Hydrologic Investigations Atlas HA-438, 1 sheet.

Fields, F.K., and Jordan, D.G., 1972, Storm-wave swash along the north coast of Puerto Rico: U.S. Geological Survey Hydrologic Investigations Atlas HA-430, 2 sheets.

Haire, W.J., 1971, Flooding along the Río Piedras in the San Juan area, Puerto Rico: U.S. Geological Survey Hydrologic Investigations Map Series no. 1, 2 sheets.

Haire, W.J., 1971, Floods in Salinas area, Puerto Rico: U.S. Geological Survey Hydrologic Investigations Atlas HA-447, 1 sheet.

Haire, W.J., 1971, Floods in the Guayama area, Puerto Rico: U.S. Geological Survey Hydrologic Investigations Atlas HA-446, 1 sheet.

Haire, W.J., 1971, Floods in the Patillas-Maunabo area, Puerto Rico: U.S. Geological Survey Hydrologic Investigations Atlas HA-445, 1 sheet.

Haire, W.J., 1971, Floods in the Santa Isabel area, Puerto Rico: U.S. Geological Survey Hydrologic Investigations Atlas HA-448, 1 sheet.

Haire, W.J., 1972, Flood of October 5-10, 1970 in Puerto Rico: U.S. Geological Survey Water-Resources Bulletin 12, 38 p.

Haire, W.J., 1972, Floods in the Río Guanajibo Valley, southwestern Puerto Rico: U.S. Geological Survey Hydrologic Investigations Atlas HA-456, 1 sheet.

Haire, W.J., 1975, Floods in the Carolina-Río Grande area, northeastern Puerto Rico: U.S. Geological Survey Hydrologic Investigations Atlas HA-533, 1 sheet.

Haire, W.J., 1975, Floods in the Fajardo-Luquillo area, northeastern Puerto Rico: U.S. Geological Survey Hydrologic Investigations Atlas HA-545, 1 sheet.

Haire, W.J., 1978, Floods in the Naguabo area, eastern Puerto Rico: U.S. Geological Survey Hydrologic Investigations Atlas HA-584, 1 sheet.

Haire, W.J., and Johnson, K.G., 1973, Floods in and near the Charlotte Amalie area, St. Thomas, U.S. Virgin Islands: U.S. Geological Survey Hydrologic Investigations Map Series no. 3, 4 sheets.

Haire, W.J., and Johnson, K.G., 1977, Floods of November 12, 1974, in the Charlotte Amalie area, St. Thomas, U.S. Virgin Islands: U.S. Geological Survey Water-Resources Investigations Report 76-91, 3 sheets.

Haire, W.J., and Johnson, K.G., 1978, Floods of November 11-13, 1974, in St. Croix, U.S. Virgin Islands: U.S. Geological Survey WaterResources Investigations Report 77-136, 11 sheets.

Hickenlooper, I.J., 1967, Floods at Barceloneta and Manatí, Puerto Rico: U.S. Geological Survey Hydrologic Investigations Atlas HA-262, 1 sheet.

Hickenlooper, I.J., 1968, Floods at Arecibo, Puerto Rico: U.S. Geological Survey Hydrologic Investigations Atlas HA-271, 1 sheet.

Hickenlooper, I.J., 1968, Floods in the area of Vega Alta and Vega Baja, Puerto Rico: U.S. Geological Survey Hydrologic Investigations Atlas HA-289, 1 sheet.

Hickenlooper, I.J., 1968, Floods in the Mayagüez area of Puerto Rico: U.S. Geological Survey Hydrologic Investigations Atlas HA-288, 1 sheet.

Hickenlooper, I.J., and López, M.A., 1967, Floods in the Ponce area, Puerto Rico: U.S. Geological Survey Hydrologic Investigations Atlas HA-261, 1 sheet.

Johnson, K.G., 1972, Floods in the Aguadilla-Aguada area, northwestern Puerto Rico: U.S. Geological Survey Hydrologic Investigations Atlas HA-457, 1 sheet.

Johnson, K.G., 1974, Floods in eastern Lajas Valley and the lower Río Loco basin, southwestern Puerto Rico: U.S. Geological Survey Hydrologic Investigations Atlas HA-532, 1 sheet.

Johnson, K.G., 1981, Flood of September 16, 1975, in Tallaboa Valley, Puerto Rico: U.S. Geological Survey Open-File Report 80-1283, 5 sheets.

Johnson, K.G., 1982, Flood of September 16, 1975, in the Guanajibo Valley, Puerto Rico: U.S. Geological Survey Open-File Report 81-805, 1 sheet. 


\section{Floods--Continued}

Johnson, K.G., 1982, Flood of September 16, 1975, in the Guayanilla Valley, Puerto Rico: U.S. Geological Survey Open-File Report 80-1282, 1 sheet.

Johnson, K.G., 1982, Flood of September 16, 1975, in the Yauco Valley, Puerto Rico: U.S. Geological Survey Open-File Report 81-331, 13 p.

Johnson, K.G., and Carrasquillo, R.A., 1982, Floods of October 9, 1970, and September 16, 1975, at Jayuya, Puerto Rico: U.S. Geological Survey Open-File Report 81-346, 1 sheet.

Johnson, K.G., and González, RaIph, 1982, Flood of September 16, 1975, in the Guánica area, Puerto Rico: U.S. Geological Survey Open-File Report 81-480, 1 sheet.

Johnson, K.G., and Quiñones-Aponte, Vicente, 1982, Flood of September 16, 1975, in the Añasco area, Puerto Rico: U.S. Geological Survey Open-File Report 81-345, 1 sheet.

Johnson, K.G., Carrasquillo, R.A., and González, Ralph, 1982, Flood of October 8, 1977, in St. Croix, U.S. Virgin Islands: U.S. Geological Survey Open-File Report 82-262, 21 p., 3 pls.

Johnson, K.G., Quiñones, Ferdinand, and Alicea, José, 1982, Flood of September 16, 1975, at Utuado, Puerto Rico: U.S. Geological Survey Open-File Report 81-413, 1 sheet.

Johnson, K.G., Quiñones, Ferdinand, and González, Ralph, 1987, Hydraulic analyses of water-surface profiles in the vicinity of the Coamo Dam and Highway 52 bridge, southern Puerto Rico; Flood analyses as related to the flood of October 7, 1985: U.S. Geological Survey WaterResources Investigations Report 87-4039, 26 p.

López, M.A., 1962, Floods at Bayamón and Cataño, Puerto Rico: U.S. Geological Survey Hydrologic Investigations Atlas HA-77, 1 sheet.

López, M.A., 1964, Floods at Toa Alta, Toa Baja, and Dorado, Puerto Rico: U.S. Geological Survey Hydrologic Investigations Atlas HA-128, 1 sheet.

López, M.A., 1967, Floods at Humacao, Puerto Rico: U.S. Geological Survey Hydrologic Investigations Atlas HA-265, 1 sheet.

López, M.A., Colón-Dieppa, EIoy, and Cobb, E.D., 1979, Floods in Puerto Rico, magnitude and frequency: U.S. Geological Survey WaterResources Investigations Report 78-141, 68 p.

Quiñones, Ferdinand, and Johnson, K.G., 1987, The floods of May 17-18, 1985, and October 6-7, 1985, in Puerto Rico: U.S. Geological Survey Open-File Report 87-123, 22 p.

Scatena, F.N., and Larsen, M.C., 1991, Physical aspects of Hurricane Hugo in Puerto Rico: Biotropica, v. 23, no. 4A, p. 317-323.

Schuck-Kolben, R.E., and Kaufman, Lionel, 1991, Storm-surge flooding by Hurricane Hugo on the U.S. Virgin Islands, Puerto Rico, and South Carolina, September 1989 - National Water Summary 1988-89: U.S. Geological Survey Water-Supply Paper 2375, p. 59-64.

\section{Geology}

Arnow, Ted, 1961, Water bearing properties of the rocks in the Arecibo-Barceloneta area, Puerto Rico: in Short Papers in the Geologic and Hydrologic Sciences, Articles 147-292, Geological Survey Research 1961, U.S. Geological Survey Professional Paper 424-C, Article 221, p. 201-202.

Briggs, R.P., and Akers, J.P., 1965, Hydrogeologic map of Puerto Rico and adjacent islands: U.S. Geological Survey Hydrologic Investigations Atlas HA-197, 1 sheet.

Cederstrom, D.J., 1950, Geology and ground-water resources of St. Croix, Virgin Islands: U.S. Geological Survey Water-Supply Paper 1067, 117 p., 1 pl.

FieIds, F.K., and Jordan, D.G., 1972, Storm-wave swash along the north coast of Puerto Rico: U.S. Geological Survey Hydrologic Investigations Atlas HA-430, 2 sheets.

Giusti, E.V., 1978, Hydrogeology of the karst of Puerto Rico: U.S. Geological Survey Professional Paper 1012, 68 p., 2 pls.

Graves, R.P., 1992, Geohydrology of the Aguirre and Pozo Hondo areas, southern Puerto Rico: U.S. Geological Survey Water-Resources Investigations Report 91-4124, 43 p.

Grossman, I.G., 1962, Stratigraphy and hydrology of the Juana Díaz Formation in the Yauco area, Puerto Rico: in Short Papers in Geology, Hydrology, and Topography, Articles 120-179, U.S. Geological Survey Professional Paper 450-D, Article 137, p. 62-63. 


\section{Geology--Continued}

Grossman, I.G., 1963, Geology of the Guánica-Guayanilla bay area, southwestern Puerto Rico: in Short Papers in Geology and Hydrology, Articles 1-59, U.S. Geological Survey Professional Paper 475-B, Article 29, p. 114-116.

Guariguata, M.R. and Larsen, M.C., 1990, Preliminary map showing locations of landslide in El Yunque quadrangle, Puerto Rico: U.S. Geological Survey Open-File Report 89-257, 1 sheet.

Jordan, D.G., 1970, Water and copper-mine tailings in karst terrane of Río Tanamá basin, Puerto Rico: U.S. Geological Survey Open-File Report 71-163, $24 \mathrm{p}$.

Larsen, M.C., 1989, Use of seismic refraction techniques for investigating morphology of recent landslides in a tropical rain forest in Puerto Rico [Abstract]: The Geological Society of America, Abstracts with Programs, v. 21, no. 3, p. 46.

Larsen, M.C., 1990, Landslides caused by the intense precipitation of Hurricane Hugo in El Yunque and surrounding areas: Boletín Oficial de la Sociedad de Historia Natural de Puerto Rico, v. 24, no. 12, p. 8.

Larsen, M.C., 1990, Landslides caused by the intense precipitation of Hurricane Hugo, September 1989, eastern Puerto Rico [Abstract]: EOS, Transactions, American Geophysical Union, v. 71, no. 6, p. 259.

Larsen, M.C., 1990, Landslides and pore pressure responses associated with Hurricane Hugo, September 1989, eastern Puerto Rico [Abstract]: The Geological Society of America, Abstracts with Programs, v. 22, no. 7, p. A331.

Larsen, M.C., 1991, Mass wasting disturbance and denudation in a humid-tropical montane forest, Puerto Rico [Abstract]: The Geological Society of America, Abstracts with Programs, v. 23, no. 5, p. A256.

Larsen, M.C., and Simon, Andrew, 1990, Landslide processes in saprolitic soils of a tropical rain forest, Puerto Rico: in Larue, D.K., and Draper, G., eds., Transactions of the 12th Caribbean Geological Conference, St. Croix, U.S. Virgin Islands, Miami Geological Society, p. 217-222.

Larsen, M.C., and Simon, Andrew, 1992, A rainfall intensity-duration threshold relation for landslide occurrence in the humid-tropical environment of Puerto Rico [Abstract]: The Geological Society of America, Abstracts with Programs, v. 24, no. 7, p. A166.

Larsen, M.C., and Torres-Sánchez, A.J., 1990, Rainfall-soil moisture relations in landslide-prone areas of a tropical rain forest, Puerto Rico: in Krishna, J.H., Quiñones-Aponte, Vicente, Gómez-Gómez, Fernando, and Morris, G.L., eds., Tropical Hydrology and Caribbean Water Resources, Proceedings of the International Symposium on Tropical Hydrology, San Juan, Puerto Rico, July 23-27, 1990, AWRA TPS-90-2, p. 121-129.

Larsen, M.C., and Torres-Sánchez, A.J., 1992, Landslides triggered by Hurricane Hugo in eastern Puerto Rico, September 1989: Caribbean Journal of Science, v. 28, no. 3-4, p. 113-125.

Monroe, W.H., 1976, The karst landforms of Puerto Rico: U.S. Geological Survey Professional Paper 899, 69 p., 1 pl.

Monroe, W.H., 1979, Map showing landslides and areas of susceptibility to landsliding in Puerto Rico: U.S. Geological Survey Miscellaneous Investigations Map Series, 1 sheet.

Monroe, W.H., 1980, Geology of the middle Tertiary Formations of Puerto Rico: U.S. Geological Survey Professional Paper 953, 93 p., 1 pl.

Monroe, W.H., 1980, Some tropical landforms of Puerto Rico: U.S. Geological Survey Professional Paper 1159, 39 p., 1 pl.

Peck, D.L., Troester, J.W., and Moore, J.E., 1988, Karst hydrogeology in the United States of America: U.S. Geological Survey Open-File Report 88-476, 19 p.

Renken, R.A., Barker, R.A., and Gómez-Gómez, Fernando, 1990, Basin analysis, paleoenvironment reconstruction and tectonic structures: Application of geologic interpretations to regional ground-water assessment in large sedimentary basins: Proceedings of the International Conference on Ground Water in Large Sedimentary Basins, Australia Water-Resources Council Conference Series no. 20, Perth, Western Australia, July 9-13, 1990, p. 80-88.

Renken, R.A., Gómez-G6mez, Fernando, Quiñones-Aponte, Vicente, and Dacosta, Rafael, 1991, Structure and depositional patterns and their influence on the hydraulic conductivity of fan-deltas in southern Puerto Rico: in Gómez-Gómez, Fernando, Quiñones-Aponte, Vicente, and Johnson, A.I., eds., Aquifers of the Caribbean Islands, Proceedings of the International Symposium on Tropical Hydrology, San Juan, Puerto Rico, July 23-27, 1990, AWRA Monograph Series no. 15, p. 25-36.

Richards, R.T., Troester, J.W., 1992, Using surface geophysical techniques to map the saline-freshwater interface and the depth to bedrock in the Valle de Yabucoa alluvial aquifer, Puerto Rico [Abstract]: Proceedings of the 17th Symposium of Natural Resources, San Juan, Puerto Rico, November 1991. 


\section{Geology--Continued}

Rodríguez-Martínez, Jesús, 1991, The hydrogeologic framework of the Northern Coastal Province Aquifer System of Puerto Rico: in GómezGómez, Fernando, Quiñones-Aponte, Vicente, and Johnson, A.I., eds., Aquifers of the Caribbean Islands, Proceedings of the International Symposium on Tropical Hydrology, San Juan, Puerto Rico, July 23-27, 1990: AWRA Monograph Series no. 15, p. 5-16.

Rodríguez-Martínez, Jesús, Hartley, J.L., and Torres-González, Arturo, 1991, Geologic and hydrologic data collected at test well NC-5, Barceloneta, Puerto Rico: U.S. Geological Survey Open-File Report 90-390, 30 p.

Rodríguez-Martínez, Jesús, Scharlach, R.A., and Torres-González, Arturo, 1991, Geologic and hydrologic data collected at test holes NC-1 and NC-3, Guaynabo and San Juan, eastern Puerto Rico: U.S. Geological Survey Open-File Report 91-217, 20 p.

Rodríguez-Martínez, Jesús, Scharlach, R.A., and Torres-González, Arturo, 1992, Geologic and hydrologic data collected at test holes NC-4 and NC-14, Manatí and Vega Baja, Puerto Rico: U.S. Geological Survey Open-File Report 92-126, 31 p.

Simon, Andrew, and Larsen, M.C., 1988, Shear strength and slope stability at sites in the Caribbean National Forest and Coamo area, Puerto Rico [Abstract]: The Geological Society of America, Abstracts with Programs, v. 20, no. 7, p. A144.

Simon, Andrew, Larsen, M.C., and Hupp, C.R., 1990, The role of soil processes in determining mechanisms of slope failure and hillslope development in a himid-tropical forest, eastern, Puerto Rico: in Kneupfer , P.L.D. and McFadden, L.D., eds., Soils and Landscape Evolution, Geomorphology, 3(1990), p. 263-286.

Torres-González, Arturo, and Gómez-Gómez, Fernando, 1982, Geohydrologic descriptions of selected solid-waste disposal sites in Puerto Rico: U.S. Geological Survey Open-File Report 81-490, 146 p.

Troester, J.W., 1992, The northern karst belt of Puerto Rico: A Humid Tropical Karst: in Back, William, Herman, J.S., and Paloc, Henri, eds., Hydrogeology of Selected Karst Regions, International Association of Hydrogeologists, v. 13, p. 475-486.

Troester, J.W., 1992, Wind as a hydrogeologic agent and cultural factor in the Lesser Antilles [Abstract]: The Geologic Society of America, Abstracts with Programs, v. 24, no. 7, p. A68.

Troester, J.W., and Moore, J.E., 1989, Karst hydrogeology in the United States of America: Episodes, v. 12, no. 3, p. 172-178.

Troester, J.W., and White, W.B.*, 1988, River knickpoints, uplift, and tilting in the northern karst belt of Puerto Rico [Abstract]: The Geological Society of America, Abstracts with Programs, v. 20, no. 7, p. 307.

Troester, J.W., Back, William, and Mora, S.C., 1987, Karst of the Caribbean: in Graf, W.L., Geomorphic Systems of North America: The Geologic Society of America, DNAG (Decade of North American Geology) Centennial Special Volume no. 2, p. $343-402$.

Yuan, Daoxian, and Troester, J.W., 1990, Evidence of climatic control on hydrogeologic processes in the karst terranes of Central China and Puerto Rico [Abstract]: Proceedings of the International Symposium and Field Seminar on Hydrogeological Processes in Karst Terranes, Antalya, Turkey, October 7-17, 1990, p. 120-121.

\section{Ground Water}

Adolphson, D.G., Seijo, M.A., and Robison, T.M., 1977, Water resources of the Maunabo Valley, Puerto Rico: U.S. Geological Survey WaterResources Investigations Report 115-76, 38 p.

Anders, R.B., 1968, Reconnaissance of the water resources of the Central Guanajibo Valley, Cabo Rojo, Puerto Rico: U.S. Geological Survey Open-File Report, 15 p.

Anders, R.B., 1971, Electric analog model study of water in the Yabucoa Valley, Puerto Rico (Phase-1, Collecting preliminary data and assembling available data): U.S. Geological Survey Open-File Report 71-5, 47 p.

Anderson, H.R., 1976, Ground water in the San Juan Metropolitan area, Puerto Rico: U.S. Geological Survey Water-Resources Investigations Report 75-41, 34 p.

Anderson, H.R., 1977, Ground water in the Lajas Valley, Puerto Rico: U.S. Geological Survey Water-Resources Investigations Report 68-76, 45 p.

Arnow, Ted, 1961, Water bearing properties of the rocks in the Arecibo-Barceloneta area, Puerto Rico: in Short Papers in the Geologic and Hydrologic, Sciences Articles 147-292, Geological Survey Research 1961, U.S. Geological Survey Professional Paper 424-C, Article 221, p. 201-202.

Arnow, Ted, and Bogart, D.B., 1959, Water problems of Puerto Rico and a program of water-resources investigations: Transactions of the Second Caribbean Geological Conference, January 4-9, 1959, Mayagüez, Puerto Rico, p. 120-129. 


\section{Ground Water--Continued}

Bennett, G.D., 1972, Ground water along Río Bucaná at Ponce, Puerto Rico - An d the effects of a proposed floodway on ground-water quality: U.S. Geological Survey Water-Resources Bulletin 11, 29 p.

Bennett, G.D., 1976, Electrical analog simulation of the aquifers along the south coast of Puerto Rico: U.S. Geological Survey Open-File Report 74-4, $101 \mathrm{p}$.

Bennett, G.D., and Giusti, E.V., 1971, Coastal ground-water flow near Ponce, Puerto Rico: in Geological Survey Research 1971, Chap. D, U.S. Geological Survey Professional Paper 750-D, p. 206-211.

Bennett, G.D., and Giusti, E.V., 1972, Ground water in the Tortuguero area, Puerto Rico - As related to proposed harbor construction: U.S. Geological Survey Water-Resources Bulletin 10, 25 p.

Bogart, D.B., Arnow, Ted, and Crooks, J.W., 1960, Water problems of Puerto Rico and a program of water-resources investigations: U.S. Geological Survey Water-Resources Bulletin 1, 40 p.

Bogart, D.B., Arnow, Ted, and Crooks, J.W., 1964, Water resources of Puerto Rico - A progress report: U.S. Geological Survey WaterResources Bulletin 4, 120 p.

Cederstrom, D.J., 1950, Geology and ground-water resources of St. Croix, Virgin Islands: U.S. Geological Survey Water-Supply Paper 1067, 117 p., 1 pl.

Colón-Dieppa, Eloy, and González, J.R., 1981, Ground-water levels in alluvium on the south coast of Puerto Rico, February 1979: U.S. Geological Survey Open-File Report 81-641, 21 p.

Colón-Dieppa, Eloy, and Mansue, L.J., 1976, Water resources of the proposed copper mining area, Puerto Rico, 1958-74 (2 Parts): U.S. Geological Survey Open-File Report 76-1 and 76-2, 414 p.

Colón-Dieppa, Eloy, and Quiñones-Márquez, Ferdinand, 1985, A reconnaissance of the water resources of the Central Río Guanajibo Valley, Puerto Rico: U.S. Geological Survey Water-Resources Investigations Report 82-4050, 47 p.

Colón-Dieppa, Eloy, Díaz, P.L., and García, René, 1987, Water resources data Puerto Rico and the U.S. Virgin Islands, Water Year 1985: U.S. Geological Survey Water-Data Report PR-85-1, 400 p.

Colón-Ramos, H.M., 1983, Ground-water records for St. Croix, U.S. Virgin Islands, 1969-1973: U.S. Geological Survey Open-File Data Report $83-546,28 \mathrm{p}$.

Colón-Ramos, Héctor, and Colón-Dieppa, Eloy, 1981, Ground-water levels and chloride concentrations in alluvial aquifers on the south coast of Puerto Rico, February 1980: U.S. Geological Survey Open-File Report 81-626, 20 p.

Conde-Costas, Carlos, and Troester, J.W., 1988. The effects of bat guano on carbonate chemistry in Cueva El Convento, Guayanilla, Puerto Rico [Abstract]: National Speleological Society, Forty-Fifth Annual Convention Program, Hot Spring, South Dakota, June 27 to July 1 , 1988 , p. 34.

Cosner, O.J., 1972, Water in St. John, U.S. Virgin Islands: U.S. Geological Survey Open-File Report 72-78, 46 p.

Crooks, J.W., Grossman, I.G., and Bogart, D.B., 1968, Water resources of the Guayanilla-Yauco area, Puerto Rico: U.S. Geological Survey Water-Resources Bulletin 5, 55 p.

Curtis, R.E., Jr., Guzmán-Ríos, Senén, and Díaz, P.L., 1984, Water resources data Puerto Rico and the U.S. Virgin Islands, Water Year 1983: U.S. Geological Survey Water-Data Report PR-83-1, 302 p.

Curtis, R.E., Jr., Guzmán-Ríos, Senén, and Díaz, P.L., 1985, Water resources data Puerto Rico and the U.S. Virgin Islands, Water Year 1984: U.S. Geological Survey Water-Data Report PR-84-1, 374 p.

Curtis, R.E., Jr., McKinley P.W., and Colón-Ramos, H.M., 1983, Water resources data Puerto Rico, Water Years 1981-82: U.S. Geological Survey Water-Data Report PR-81-82-1, 414 p.

Curtis, R.E., Jr., Aquino, Zaida, Díaz, P.L., and García, René, 1988, Water resources data Puerto Rico and the U.S. Virgin Islands, Water Year 1986: U.S. Geological Survey Water-Data Report PR-86-1, 362 p.

Curtis, R.E., Jr., Aquino, Zaida, Díaz, P.L., and Vachier, Ricardo, 1989, Water resources data Puerto Rico and the U.S. Virgin Islands, Water Year 1987: U.S. Geological Survey Water-Data Report PR-87-1, 356 p.

Curtis, R.E., Jr., Aquino, Zaida, Díaz, P.L., and Vachier, Ricardo, 1989, Water resources data Puerto Rico and the U.S. Virgin Islands, Water Year 1988: U.S. Geological Survey Water-Data Report PR-88-1, 460 p. 


\section{Ground Water--Continued}

Curtis, R.E., Jr., Aquino, Zaida, Díaz, P.L., and Vachier, Ricardo, 1990, Water resources data Puerto Rico and the U.S. Virgin Islands, Water Year 1989: U.S. Geological Survey Water-Data Report PR-89-1, 419 p.

Curtis, R.E., Jr., Aquino, Zaida, Díaz, P.L., and Vachier, Ricardo, 1991, Water resources data Puerto Rico and the U.S. Virgin Islands, Water Year 1990: U.S. Geological Survey Water-Data Report PR-90-1, 514 p.

Dacosta, Rafael, and Gómez-Gómez, Fernando, 1987, Potentiometric surface of the alluvial aquifer and hydrologic conditions in the Guayama quadrangle, Puerto Rico, March 1986: U.S. Geological Survey Water-Resources Investigations Report 87-4162, 1 sheet.

Díaz, J.R., 1971, Electric analog model study of water in the Guayama area, Puerto Rico (Phase-1, Assembling data for the analog model): U.S. Geological Survey Open-File Report 71-86, 68 p.

Díaz, J.R., 1973, Chemical quality of water in Caño Tiburones, Puerto Rico: A reconnaissance study carried out in 1967: U.S. Geological Survey Open-File Report Map Series no. 2, 2 pls.

Díaz, J.R., 1974, Coastal salinity reconnaissance and monitoring system--south coast of Puerto Rico: U.S. Geological Survey Open-File Report 74-1, $28 \mathrm{p}$.

Díaz, J.R., 1977, Ground-water levels in alluvium on the south coast of Puerto Rico, February 1977: U.S. Geological Survey Open-File Report 77$696,6 \mathrm{p}$.

Díaz, J.R., 1977, Ground-water levels on the south coast of Puerto Rico, February 1974 to February 1975: U.S. Geological Survey Open-File Report 76-625, 30 p.

Díaz, J.R., 1979, Ground-water levels in alluvium on the south coast of Puerto Rico, February 1978: U.S. Geological Survey Open-File Report $79-1272,18 \mathrm{p}$.

Díaz, J.R., 1979, Seawater intrusion, south coast of Puerto Rico, 1966-77: U.S. Geological Survey Open-File Report 79-1334, 20 p.

Díaz, J.R., and Jordan, D.G., 1987, Water resources of the Río Grande de Añasco - lower Valley, Puerto Rico: U.S. Geological Survey WaterResources Investigations Report 85-4237, 48 p.

Durfor, C.N., and Becker, Edith, 1964, Chemical quality of public water supplies of the United States and Puerto Rico, 1962: U.S. Geological Survey Hydrologic Investigations Atlas HA-200, 1 sheet.

Ellins, K.K., Román-Más, Angel, and Lee, R.N., 1986, Estimating ground-water influx to a portion of the Río Grande de Manatí River basin in Puerto Rico through the measurement of ${ }^{222} \mathrm{Rn}$ : in Quiñones, Ferdinand, Sánchez, A.V., and Smith, H.H., eds., Proceedings of the Third Caribbean Islands Water-Resources Congress, U.S. Virgin Islands, July 22-25, 1986, Puerto Rico Water Resources Association, p. 27.

Fields, F.K., and Jordan, D.G., 1972, Storm-wave swash along the north coast of Puerto Rico: U.S. Geological Survey Hydrologic Investigations Atlas HA-430, 2 sheets.

García, René, and Canoy, Michael, 1984, Reconnaissance of ground-water quality in the Virgin Islands, July 1984: U.S. Geological Survey Open-File Data Report 84-807, 1 sheet.

Giusti, E.V., 1968, Water resources of the Juana Díaz area, Puerto Rico - A preliminary appraisal, 1966: U.S. Geological Survey WaterResources Bulletin 8, 43 p.

Giusti, E.V., 1971, Regional specific yield of the Coamo Fan, Puerto Rico, computed by the water budget method: in Geological Survey Research 1971, Chap. B, U.S. Geological Survey Professional Paper 750-B, p. 248-251.

Giusti, E.V., 1971, Water resources of the Coamo area, Puerto Rico: U.S. Geological Survey Water-Resources Bulletin 9, 31 p.

Giusti, E.V., and Bennett, G.D., 1976, Water resources of the north coast limestone area, Puerto Rico: U.S. Geological Survey Water-Resources Investigations Report 75-42, $42 \mathrm{p}$

Gómez-Gómez, Fernando, 1979, Reconnaissance of six solid-waste disposal sites in Puerto Rico and effects on water quality: U.S. Geological Survey Open-File Report 79-1338, 73 p.

Gómez-Gómez, Fernando, 1984, Water resources of the lower Río Grande de Manatí Valley: U.S. Geological Survey Water-Resources Investigations Report 83-4199, 42 p.

Gómez-Gómez, Fernando, 1986, Caribbean Islands Regional Aquifer-System Study - Phase 1, Regional Aquifer-System Study projects started in 1984: in Ren Jen Sun, ed., Summary of Projects 1978-84: U.S. Geological Survey Circular 1002, p. 234-241. 


\section{Ground Water--Continued}

Gómez-Gómez, Fernando, 1987, Planning report for the Caribbean Islands Regional Aquifer-System Analysis project: U.S. Geological Survey Water-Resources Investigations Report 86-4074, 50 p., 3 pls.

Gómez-Gómez, Fernando, 1990, Hydrochemistry of the South Coastal Plain Aquifer System of Puerto Rico and its relation to surface-water recharge: in Gómez-Gómez, Fernando, Quiñones-Aponte, Vicente, and Johnson, A.I., eds., Aquifers of the Caribbean Islands, Proceedings of the International Symposium on Tropical Hydrology, San Juan, Puerto Rico, July 23-27, 1990, AWRA Monograph Series no. 15, p. 57-75.

Gómez-Gómez, Fernando, and Guzmán-Ríos, Senén, 1982, Reconnaissance of ground-water quality throughout Puerto Rico, SeptemberOctober 1981: U.S. Geological Survey Open-File Report 82-332, 1 sheet.

Gómez-Gómez, Fernando, and Heisel, J.E., 1980, Summary appraisals of the Nation's ground-water resources - Caribbean Region: U.S. Geological Survey Professional Paper 813-U, 32 p., 2 pls.

G6́mez-Gómez, Fernando, and Torres-Sierra, Heriberto, 1988, Hydrology and effects of development on the water-table aquifer in the Vega Alta quadrangle, Puerto Rico: U.S. Geological Survey Water-Resources Investigations Report 87-4105, 54 p.

Gómez-Gómez, Fernando, Quiñones, Ferdinand, and López, Marisol, 1984, Public water supplies in Puerto Rico, 1983: U.S. Geological Survey Open-File Data Report 84-126, 102 p.

Gómez-Gómez, Fernando, Quiñones-Márquez, Ferdinand, and Zack, A.L., 1984, U.S. Virgin Islands ground-water resources -National Water Summary 1984: U.S. Geological Survey Water Supply Paper 2275, p. 409-413.

Graves, R.P., 1989, Water resources of the Humacao-Naguabo area, eastern Puerto Rico: U.S. Geological Survey Water-Resources Investigations Report 87-4088, 69 p.

Graves, R.P., 1991, Ground-water resources in Lajas Valley, Puerto Rico: U.S. Geological Survey Water-Resources Investigations Report $89-4182,55 \mathrm{p}$.

Graves, R.P., 1992, Geohydrology of the Aguirre and Pozo Hondo areas, southern Puerto Rico: U.S. Geological Survey Water-Resources Investigations Report 91-4124, 43 p.

Graves, R.P., and González, Ralph, 1988, Potentiometric surface of the Turpentine Run basin aquifer in the Tutu area, eastern St. Thomas, U.S. Virgin Islands, September 11, 1987: U.S. Geological Survey Water-Resources Investigations Report 88-4131, 1 sheet.

Grossman, I.G., 1959, Ground-water data from St. Thomas, Virgin Islands: U.S. Geological Survey Open-File Report, 35 p., 5 pls.

Grossman, I.G., 1961, Ground-water conditions in the lower Tallaboa Valley, Puerto Rico: in Short Papers in the Geologic and Hydrologic Sciences, Articles 147-292, U.S. Geological Survey Professional Paper 424-C, Article 222, p. 202-203.

Grossman, I.G., 1962, Chemical quality of ground water in St. Thomas, Virgin Islands: in Short Papers in Geology, Hydrology, and Topography, Articles 1-59, U.S. Geological Survey Professional Paper 450-B, Article 55, p. 131-133.

Grossman, I.G., 1966, Fluctuations of ground-water levels in Puerto Rico resulting from earthquakes (1959-1961) [Abstract]: Transactions of the Third Caribbean Geological Conference, Kingston, Jamaica, April 1962, p. 104-105.

Grossman, I.G., Bogart, D.B., Crooks, J.W., and Díaz, J.R., 1972, Water resources of the Tallaboa Valley, Puerto Rico: U.S. Geological Survey Water-Resources Bulletin 7, $115 \mathrm{p}$.

Guzmán-Ríos, Senén, 1983, Reconnaissance of the principal springs of Puerto Rico, 1982-83: U.S. Geological Survey Open-File Data Report 83-683, 1 sheet.

Guzmán-Ríos, Senén, 1988, Hydrology and water quality of the principal springs in Puerto Rico: U.S. Geological Survey Water-Resources Investigations Report 85-4269, 30 p.

Guzmán-Ríos, Senén, and Quiñones-Márquez, Ferdinand, 1984, Ground-water quality at selected sites throughout Puerto Rico, September 1982 - July 1983: U.S. Geological Survey Open-File Data Report 84-058, 1 sheet.

Guzmán-Ríos, Senén, and Quiñones-Márquez, Ferdinand, 1985, Reconnaissance of trace organic compounds in ground water throughout Puerto Rico, October 1983: U.S. Geological Survey Open-File Data Report 84-810, 1 sheet.

Heisel, J.E., and González, J.R., 1976, Ground-water levels on the south coast of Puerto Rico, February 1976: U.S. Geological Survey Open-File Report 76-705, 13 p.

Heisel, J.E., and González, J.R., 1979, Water budget and hydraulic aspects of artificial recharge, south coast of Puerto Rico: U.S. Geological Survey Water-Resources Investigations Report 78-58, 102 p. 


\section{Ground Water--Continued}

Heisel, J.E., González, J.R., and Cruz, Carlos, 1983, Analog model analysis of the north coast limestone aquifers, Puerto Rico: U.S. Geological Survey Open-File Report 82-52, 49 p.

Hendrickson, G.E., 1962, Development of the ground-water resources of St. Croix, Virgin Islands: U.S. Geological Survey Open-File Report, $84 \mathrm{p}$.

Hendrickson, G.E., 1963, Ground water for public supply in St. Croix, Virgin Islands: U.S. Geological Survey Water-Supply Paper 1663-D, $27 \mathrm{p}$.

Jordan, D.G., 1970, Water and copper-mine tailings in karst terrane of Río Tanamá basin, Puerto Rico: U.S. Geological Survey Open-File Report $71-163,24 \mathrm{p}$.

Jordan, D.G., 1972, Land-use effect on the water regimen of the U.S. Virgin Islands: in Geological Survey Research 1972, Chap. D, U.S. Geological Survey Professional Paper 800-D, p. 211-216.

Jordan, D.G., 1975, A survey of the water resources of St. Croix, Virgin Islands: U.S. Geological Survey Open-File Report 73-137, 51 p.

Jordan, D.G., and Cosner, O.J., 1973, A survey of the water resources of St. Thomas, Virgin Islands: U.S. Geological Survey Open-File Report $72-201,55 \mathrm{p}$.

Jordan, D.G., and Gilbert, B.K., 1976, Water supply and waste disposal, Culebra, Puerto Rico: U.S. Geological Survey Water-Resources Investigations $76-3,31 \mathrm{p}$.

Kipple, F.P., and others, 1968, Water records of Puerto Rico, 1958-63: U.S. Geological Survey Water-Data Report, 353 p.

Lohr, E.W., 1957, Chemical character of public water supplies of the larger cities in Alaska, Hawaii, and Puerto Rico, 1954: U.S. Geological Survey Water-Supply Paper 1460-A, 39 p., 1 pl.

McClymonds, N.E., 1967, Water resources of the Guánica area, Puerto Rico - A preliminary appraisal, 1963: U.S. Geological Survey WaterResources Bulletin 6, 43 p.

McClymonds, N.E., 1972, Water resources of the Ponce area, Puerto Rico: U.S. Geological Survey Water-Resources Bulletin 14, 26 p.

McClymonds, N.E., and Díaz, J.R., 1972, Water resources of the Jobos area, Puerto Rico - A preliminary appraisal, 1962: U.S. Geological Survey Water-Resources Bulletin 13, 32 p.

McClymonds, N.E., and Ward, P.E., 1966, Hydrologic characteristics of the alluvial fan near Salinas, Puerto Rico: in Geological Survey Research 1966, Chap. C, U.S. Geological Survey Professional Paper 550-C, p. 231-234.

McCoy, J.H., 1978, Summary of the water resources of Puerto Rico: U.S. Geological Survey Open-File Report 78-971, 24 p.

McGuinness, C.L., 1946, Ground-water reconnaissance of Vieques Island, Puerto Rico: U.S. Geological Survey Open-File Report.

McGuinness, C.L., 1946, Records of wells in Puerto Rico: U.S. Geological Survey Open-File Report, 267 p.

McGuinness, C.L., 1948, Ground-water resources of Puerto Rico: U.S. Geological Survey Open-File Report, 277 p.

McGuinness, C.L., 1953, Summary of the water resources of the Virgin Islands: U.S. Geological Survey Open-File Report, 8 p.

Puig, J.C., and Rodríguez, J.M., 1990, Potentiometric surface of the alluvial aquifer and hydrologic conditions near Gurabo and Juncos, Puerto Rico, March 1988: U.S. Geological Survey Water-Resources Investigations Report 90-4059, 2 sheets.

Puig, J.C., and Rodríguez, J.M., 1992, Ground-water resources of the Caguas-Juncos Valley, Puerto Rico: U.S. Geological Survey WaterResources Investigations Report 91-4079, 48 p.

Puig, J.C., Rodríguez-del-Río, Félix, and Rodríguez, J.M., 1989, Potentiometric surface of the alluvial aquifer and hydrologic conditions near Caguas, Puerto Rico, March 1988: U.S. Geological Survey Water-Resources Investigations Report 89-4075, 1 sheet.

Puig, J.C., Rolón-Collazo, L.I., and Pagán-Trinidad, Ismael*, 1990, Development of an aquifer management model: AQMAN3D: in Krishna, J.H., Quiñones-Aponte, Vicente, Gómez-Gómez, Fernando, and Morris, G.L., eds., Tropical Hydrology and Caribbean Water Resources, Proceedings of the International Symposium on Tropical Hydrology, San Juan, Puerto Rico, July 23-27, 1990, AWRA TPS-90-2, p. 39-48.

Quiñones, Ferdinand, and Alicea, José, 1981, Water resources investigations in Puerto Rico and the U.S. Virgin Islands - Programs and activities of the U.S. Geological Survey, Water Resources Division, Caribbean District: U.S. Geological Survey Open-File Report, 69 p.

Quiñones, Ferdinand, and Alicea, José, 1983, Water resources investigations in Puerto Rico and the U.S. Virgin Islands - Programs and activities of the U.S. Geological Survey, Water Resources Division, Caribbean District: U.S. Geological Survey Open-File Report, 28 p. 


\section{Ground Water--Continued}

Quiñones, Ferdinand, and Alicea, José, 1984, Water resources investigations in Puerto Rico and the U.S. Virgin Islands - Programs and activities of the U.S. Geological Survey, Water Resources Division, Caribbean District: U.S. Geological Survey Open-File Report, 41 p.

Quiñones, Ferdinand, and Alicea-Ortíz, José, 1985, Agua subterránea en Puerto Rico: U.S. Geological Survey Open-File Report 85-642, 6 p.

Quiñones-Márquez, Ferdinand, 1981, Ground-water levels in the south coast of Puerto Rico, February 1969-71: U.S. Geological Survey OpenFile Data Report PR-1-71.

Quiñones-Márquez, Ferdinand, 1987, Management and development of surface and ground water: in Krushesky, R.D., ed., Proceedings of the Development of Mineral, Energy, and Water Resources and Mitigation of Geologic Hazards in Central America, U.S. Geological Survey Circular 1006, p. 140-149.

Quiñones-Márquez, Ferdinand, Gómez-Gómez, Fernando, and Zack, Allen, 1984, Puerto Rico ground-water resources - National Water Summary 1984: U.S. Geological Survey, Water-Supply Paper 2275, p. 367-372.

Quiñones-Aponte, Vicente, 1986, Simulation of ground-water flow in the Río Yauco alluvial valley, Yauco, Puerto Rico: U.S. Geological Survey Water-Resources Investigations Report 85-4179, 32 p.

Quiñones-Aponte, Vicente, 1986, Water resources of the lower Río Grande de Arecibo alluvial valley, Puerto Rico: U.S. Geological Survey Water-Resources Investigations Report 85-4160, 38 p., 1 pl.

Quiñones-Aponte, Vicente, 1987, Effects of the channelization of Río Bucaná on the ground-water resources north of the Ponce Valley, Puerto Rico; Numerical analysis: Proceedings of the 12th Natural Resources Symposium, San Juan, Puerto Rico, December 11-12, 1985, Puerto Rico Department of Natural Resources (Published in Spanish), 4 p.

Quiñones-Aponte, Vicente, 1988, Effects of the horizontal anisotropy on the determination of storage coefficient [Abstract]: International Conference on Advances in Ground-Water Hydrology, Tampa, Florida, November 16-18, 1988, American Institute of Hydrology.

Quiñones-Aponte, Vicente, 1989, Comparison of aquifer storage coefficients computed using anisotropic and isotropic analytical models: Proceedings of the Recent Advances in Ground-Water Hydrology, American Institute of Hydrology, p. 349-357.

Quiñones-Aponte, Vicente, 1989, Horizontal Anisotropy of the principal ground-water flow zone in the Salinas alluvial fan, Puerto Rico: Ground Water Journal, v. 27, no. 4, p. 491-500.

Quiñones-Aponte, Vicente, 1989, Hydrogeologic characteristics of the lower Río Grande de Arecibo alluvial valley: Proceedings of the 13th Natural Resources Symposium, San Juan, Puerto Rico, February 26, 1987, Puerto Rico Department of Natural Resources, p. 41-59.

Quiñones-Aponte, Vicente, 1988, Recovery efficiency from single-well injection/recovery tests in a limestone aquifer of high secondary porosity: Proceedings of the American Society of Civil Engineers, Irrigation and Drainage Division, Artificial Recharge of Ground Water, International Symposium, Anaheim, California, August 1988, p. 54-63.

Quiñones-Aponte, Vicente, 1991, Water-resources development and its influence on the water budget for the aquifer system in the Salinas to Patillas area, Puerto Rico: in Gómez-Gómez, Fernando, Quiñones-Aponte, Vicente, and Johnson, A.I., eds., Aquifers of the Caribbean Islands, Proceedings of the International Symposium on Tropical Hydrology, San Juan, Puerto Rico, July 23-27, 1990, AWRA Monograph Series no. 15, p. 37-55.

Quiñones-Aponte, Vicente, and Carrasquillo, R.A., 1986, Use of borehole neutron logs to estimate moisture content in the unsaturated zone of an alluvial aquifer: in Quiñones, Ferdinand, Sánchez, A.V., and Smith, H.H., eds., Proceedings of the Third Caribbean Islands WaterResources Congress, U.S. Virgin Islands, July 22-25, 1986, Puerto Rico Water Resources Association, p. 57-60.

Quiñones-Aponte, Vicente, and Gómez-Gómez, Fernando, 1987, Potentiometric surface of the alluvial aquifer and hydrologic conditions in the Salinas quadrangle, Puerto Rico, March 1986: U.S. Geological Survey Water-Resources Investigations Report 87-4161, 1 sheet.

Quiñones-Aponte, Vicente, and Torres-Sierra, Heriberto, 1985, Application of a ground-water flow digital model in evaluating alternate dewatering systems in the Río Grande de Arecibo alluvial valley, Puerto Rico: Proceedings of the Tropical Hydrology and Second Caribbean Islands Water-Resources Congress, May 5-8, 1985, American Water Resources Association, Technical Publication Series TPS-85-1, p. 129-134.

Quiñones-Aponte, Vicente, Whitesides, D.V., and Zack, Allen, 1989, Single-well injection and recovery of freshwater from an aquifer containing saline water at Arecibo, Puerto Rico: U.S. Geological Survey Water-Resources Investigations Report 88-4037, 19 p. 


\section{Ground Water--Continued}

Quiñones-Márquez, Ferdinand, 1987, Management and development of surface and ground water: in Krushesky, R.D., ed., Proceedings of the Development of Mineral, Energy, and Water Resources and Mitigation of Geologic Hazards in Central America, U.S. Geological Survey Circular 1006, p. 140-149.

Quiñones-Márquez, Ferdinand, and Peña-Cruz, Gilberto, 1985, Water resources investigations in Puerto Rico and the U.S. Virgin Islands Programs and activities of the U.S. Geological Survey, Water Resources Division, Caribbean District 1984-1985: U.S. Geological Survey Open-File Report 85-556, 43 p.

Quiñones-Márquez, Ferdinand, Gómez-Gómez, Fernando, and Zack, Allen, 1984, Puerto Rico ground-water resources - National Water Summary 1984: U.S. Geological Survey Water-Supply Paper 2275, p. 367-372.

Quiñones-Márquez, Ferdinand, López, M.A., and Latkovich, V.J., 1976, Water records of the Río Piedras basin, Puerto Rico, 1971-74: U.S. Geological Survey Open-File Report 76-3, 111 p.

Ramos-Ginés, Orlando, 1991, Elevation of water table and hydrologic conditions in the Río Lapa to Río Majada area, Puerto Rico, for December 1988, and April, July, and October 1989: U.S. Geological Survey Water-Resources Investigations Report 90-4125, 4 p., 1 sheet.

Renken, R.A., Barker, R.A., and Gómez-Gómez, Fernando, 1990, Basin analysis, paleoenvironment reconstruction and tectonic structures: Application of geologic interpretations to regional ground-water assessment in large sedimentary basins: Proceedings of the International Conference on Ground Water in Large Sedimentary Basins, Australia Water-Resources Council Conference Series no. 20, Perth, Western Australia, July 9-13, 1990, p. 80-88.

Renken, R.A., Díaz, Pedro, Gómez-Gómez, Fernando, and Quiñones-Aponte, Vicente, 1990, Hydrologic excursion to Puerto Rico's Southern Plain: U.S. Geological Survey Open-File Report 90-365, 24 p., 1 pl.

Renken, R.A., Gómez-Gómez, Fernando, Quiñones-Aponte, Vicente, and Dacosta, Rafael, 1991, Structure and depositional patterns and their influence on the hydraulic conductivity of fan-deltas in southern Puerto Rico: in Gómez-Gómez, Fernando, Quiñones-Aponte, Vicente, and Johnson, A.I., eds., Aquifers of the Caribbean Islands, Proceedings of the International Symposium on Tropical Hydrology, San Juan, Puerto Rico, July 23-27, 1990, AWRA Monograph Series no. 15, p. 25-36.

Richards, R.T., Troester, J.W., 1992, Using surface geophysical techniques to map the saline-freshwater interface and the depth to bedrock in the Valle de Yabucoa alluvial aquifer, Puerto Rico [Abstract]: Proceedings of the 17th Symposium of Natural Resources, San Juan, Puerto Rico, November 1991.

Rickler, J.G., and others, 1970, Water records of Puerto Rico, 1964-67, Volume 1, north and northeast slopes: U.S. Geological Survey WaterData Report 71-238, 265 p.

Rickler, J.G., and others, 1970, Water records of Puerto Rico, 1964-67, Volume 2, south and west slopes: U.S. Geological Survey Water-Data Report, 308 p.

Robison, T.M., 1971, Earthquake-accelerated decline of water level in an observation well in St. Thomas, Virgin Islands: U.S. Geological Survey Professional Paper 750-B, p. 252-253.

Robison, T.M., 1972, Ground water in central St. Croix, U.S. Virgin Islands: U.S. Geological Survey Open-File Report, 18 p.

Robison, T.M., and Anders, R.B., 1973, Electric analog model study of the alluvial aquifer in the Yabucoa Valley, Puerto Rico (Phase 2--The planning, construction, and use of the model): U.S. Geological Survey Open-File Report 73-242, 47 p.

Robison, T.M., and others, 1972, Water records of the U.S. Virgin Islands, 1962-69: U.S. Geological Survey Water-Data Report, 163 p.

Rodríguez-del-Río, Félix, and Gómez-Gómez, Fernando, 1990, Potentiometric surface of the alluvial aquifer and hydrologic conditions in the Santa Isabel-Juana Díaz area, Puerto Rico, March to April 1987: U.S. Geological Survey Water-Resources Investigations Report 89-4116, 1 sheet.

Rodríguez-del-Río, Félix, and Quiñones-Aponte, Vicente, 1990, Potentiometric surface of the principal aquifer and hydrologic conditions in the Ponce-Juana Díaz area, Puerto Rico, April to May 1987: U.S. Geological Survey Water-Resources Investigations Report 89-4115, 1 sheet.

Rodríguez-Martínez, Jesús, 1991, The hydrogeologic framework of the Northern Coastal Province Aquifer System of Puerto Rico: in GómezGómez, Fernando, Quiñones-Aponte, Vicente, and Johnson, A.I., eds., Aquifers of the Caribbean Islands, Proceedings of the International Symposium on Tropical Hydrology, San Juan, Puerto Rico, July 23-27, 1990: AWRA Monograph Series no. 15, p. 5-16.

Rolón-Collazo, L.I., and González, Philip, 1990, An interactive computer program, GWARC, to create a geographic information system data set from ground-water site inventory data [Abstract]: National Computer Technology Meeting, May 7-11, 1990, Programs and Abstracts, U.S. Geological Survey Open-File Report 90-161, p. 34. 


\section{Ground Water--Continued}

Román-Más, Angel, 1986, Role of blanket deposits on the hydrology and water chemistry of the limestone water-table aquifer within the north coast of Puerto Rico through interpretation of geochemical data: in Quiñones, Ferdinand, Sánchez, A.V., and Smith, H.H., eds., Proceedings of the Third Caribbean Islands Water-Resources Congress, U.S. Virgin Islands, July 22-25, 1986, Puerto Rico Water Resources Association, p. 33.

Román-Más, Angel, and Lee, R.W., 1985, Water quality and chemical evolution of ground water within the north coast limestone aquifers of Puerto Rico: Proceedings of the Tropical Hydrology and Second Caribbean Islands Water-Resources Congress, May 5-8, 1985, American Water Resources Association, Technical Publication Series TPS-85-1, p. 57-63.

Román-Más, Angel, and Lee, R.W., 1987, Geochemical evolution of waters within the north coast limestone aquifers of Puerto Rico: A conceptualization based on a flow path in the Barceloneta area: U.S. Geological Survey Water-Resources Investigations Report 86-4080, $28 \mathrm{p}$.

Román-Más, Angel, and Ramos-Ginés, Orlando, 1987, Elevation of the water-table surface for the alluvial aquifer and hydrologic conditions in the Santa Isabel-Juana Díaz area, Puerto Rico, March 1986: U.S. Geological Survey Water-Resources Investigations Report 87-4123, 2 sheets.

Román-Más, Angel, and Ramos-Ginés, Orlando, 1988, Compilation of water-quality data for the north coast limestone aquifers, Puerto Rico, 1951 to 1987: U.S. Geological Survey Open-File Data Report 87-533, 133 p.

Sepulveda, Nicasio, 1991, Solution of the one-dimensional consolidation theory equation with a Pseudospectral Method: Proceedings of the Fourth International Association of Hydrological Sciences, Symposium on Land Subsidence, Houston, Texas, IAHS no. 200 , p. $555-564$.

Sépulveda, Nicasio, 1992, Computer algorithm for the analysis of underdamped and overdamped water-level responses in slug tests: U.S. Geological Survey Water Resources-Investigations Report 91-4162, 20 p.

Sepulveda, Nicasio, and Zack, A.L., 1990, Laboratory simulation of the effects of overburden stress on the specific storage of shallow artesian aquifers: in Krishna, J.H., Quiñones-Aponte, Vicente, Gómez-Gómez, Fernando, and Morris, G.L., eds., Tropical Hydrology and Caribbean Water Resources, Proceedings of the International Symposium on Tropical Hydrology, San Juan, Puerto Rico, July 23-27, 1990, AWRA TPS-90-2, p. 349-356.

Stevens, K.E., Gómez-Gómez, Fernando, and Alicea, José, 1981, Water wells in the U.S. Virgin Islands, Part 1, St. Thomas: U.S. Geological Survey Open-File Report 82-82, 112 p.

Torres-González, Arturo, 1981, Hydrology of the Río Camuy caves system, Puerto Rico [Abstract]: Proceedings of the Eighth International Congress of Speleology, July 18-24, 1981, Kentucky, no. 8, p. 475.

Torres-González, Arturo, 1985, Simulation of ground-water flow in the water table aquifer near Barceloneta, Puerto Rico: U.S. Geological Survey Water-Resources Investigations Report 84-4113, 39 p.

Torres-González, Arturo, 1985, Use of surface-geophysical techniques for ground-water exploration in the Canбvanas-Río Grande area, Puerto Rico: U.S. Geological Survey Water-Resources Investigations Report 83-4266, 29 p.

Torres-González, Arturo, and Díaz, J.R., 1984, Water resources of the Sabana Seca to Vega Baja area, Puerto Rico: U.S. Geological Survey Water-Resources Investigations Report 82-4115, 53 p.

Torres-González, Arturo, and Wolansky, R.M., 1984, Planning report for the comprehensive appraisal of the ground-water resources of the north coast limestone area of Puerto Rico: U.S. Geological Survey Open-File Data Report 84-427, 32 p.

Torres-González, Sigfredo, 1984, Water-resources investigations of Vieques Island, Puerto Rico: Proceedings of the First Caribbean Islands Water-Resources Congress, St. Thomas, U.S. Virgin Islands, July 26-27, 1984, p. 298-311.

Torres-González, Sigfredo, 1989, Reconnaissance of the ground-water resources of Vieques Island, Puerto Rico: U.S. Geological Survey WaterResources Investigations Report 86-4100, 37 p.

Torres-González, Sigfredo, 1991, Compilation of ground-water level measurements obtained by the United States Geological Survey in Puerto Rico, 1958-1985: U.S. Geological Survey Open-File Data Report 88-701, 163 p.

Torres-González, Sigfredo, 1991, Steady-state simulation of ground-water flow conditions in the Kingshill aquifer, St. Croix, U.S. Virgin Islands, July 1987: in Gómez-Gómez, Fernando, Quiñones-Aponte, Vicente, and Johnson, A.I., eds., Aquifers of the Caribbean Islands, Proceedings of the International Symposium on Tropical Hydrology, San Juan, Puerto Rico, July 23-27, 1990, AWRA Monograph Series no. 15, p. 93-108.

Torres-González, Sigfredo, and Gómez-Gómez, Fernando, 1987, Potentiometric surface of the alluvial aquifer and hydrologic conditions in the Central Aguirre quadrangle, Puerto Rico, March 1986: U.S. Geological Survey Water-Resources Investigations Report 87-4160, 1 sheet. 


\section{Ground Water--Continued}

Torres-González, Sigfredo, and Rodríguez-del-Río, Félix, 1990, Potentiometric surface of the Kingshill aquifer and hydrologic conditions, St. Croix, U.S. Virgin Islands, July 1987: U.S. Geological Survey Water-Resources Investigations Report 89-4085, 1 sheet.

Torres-González, Sigfredo, and Rolón-Collazo, L.I., 1990, The interactive computer program MODUMANAG, a data management tool for the modular finite-difference ground-water flow model: in Krishna, J.H., Quiñones-Aponte, Vicente, Gómez-Gómez, Fernando, and Morris, G.L., eds., Tropical Hydrology and Caribbean Water Resources, Proceedings of the International Symposium on Tropical Hydrology, San Juan, Puerto Rico, July 23-27, 1990, AWRA TPS-90-2, p. 403-410.

Torres-Sierra, Heriberto, 1985, Potentiometric surface of the upper limestone aquifer in the Dorado-Vega Alta area, north-central Puerto Rico, February 1983: U.S. Geological Survey Water-Resources Investigations Report 85-4268, 1 sheet.

Troester, J.W., 1988, U.S. Geological Survey ground-water studies in Puerto Rico: U.S. Geological Survey Water Fact Sheet, Open-File Report $88-162,2$ p.

Troester, J.W., 1988, U.S. Geological Survey ground-water studies in the U.S. Virgin Islands: U.S. Geological Survey Water Fact Sheet, OpenFile Report 88-163, 2 p.

Troester, J.W., and White, W.B., 1988, The carbonate chemistry of the Río Camuy drainage basin, Puerto Rico: A Humid Tropical Karst [Abstract]: National Speleological Society, Annual Convention Program, p. 34.

Troester, J.W., and White, W.B., 1989, Carbonate chemistry and hydrogeology of Río Camuy drainage basin, Puerto Rico [Abstract]: Humid Tropical Karst 28th International Geologic Congress, Washington D.C., July 9-19, 1989, v. 3, p. 255.

Troester, J.W., Collar, P.D., Robinson, P.D., and Deike, R.G., 1990, Geochemical processes controlling manganese and iron concentrations in the ground water of the Valle de Yabucoa alluvial aquifer, Puerto Rico [Abstract]: EOS, Transactions, American Geophysical Union, April 24, 1990 , v. 71, no. 17 , p. 506 .

Troester, J.W., Deike, R.G., Robinson, P.D., and Collar, P.D., 1990, Petrographic analyses and geochemical modeling of aquequs/solid phase reactions in the Valle de Yabucoa alluvial aquifer, Puerto Rico [Abstract]: The Geological Society of America, Abstracts with Programs, p. A295.

U.S. Geological Survey, 1973, Water resources data for Puerto Rico, 1968-72, Part 3, Ground water records: U.S. Geological Survey Water-Data Report, 78 p.

U.S. Geological Survey, 1978, Water resources data for Puerto Rico, Surface and quality-of-water records, Water Years 1975-76, Ground water records, Water Years 1973-76: U.S. Geological Survey Water-Data Report-PR-76-1, 366 p.

U.S. Geological Survey, 1979, Water-resources investigations in Puerto Rico and the U.S. Virgin Islands, 1978: U.S. Geological Survey Folder.

U.S. Geological Survey, 1981, Water resources data for Puerto Rico, Water Year 1978: U.S. Geological Survey Water-Data Report PR-78-1, $255 \mathrm{p}$.

U.S. Geological Survey, 1982, Water resources data for Puerto Rico, Water Years 1979-80: U.S. Geological Survey Water-Data Report PR-79-80, $408 \mathrm{p}$.

U.S. Geological Survey, 1983, Puerto Rico and the U.S. Virgin Islands water issues: National Water Summary 1983 - Hydrologic Events and Issues, U.S. Geological Survey Water-Supply Paper 2250, p. 200-202.

Vaughan, T.W., 1920, The ground-water resources of the West Indian Islands, St. John, St. Thomas, Culebra and Vieques, and of the eastern end of Puerto Rico: U.S. Geological Survey Open-File report.

Veve, T.D., and Troester, J.W., 1990, Water-resources investigations in Puerto Rico and the U.S. Virgin Islands, 1986-1988: U.S. Geologic Survey Open-File Report 90-122, 39 p.

Ward, P.E., and Truxes, C.S., 1964, Water wells in Puerto Rico: U.S. Geological Survey Water-Resources Bulletin 3, 249 p.

Whitesides, D.V., Quiñones-Aponte, Vicente, and Zack, A.L., 1985, Estimating the capacity of a salty limestone aquifer in Puerto Rico to receive, store, and release injected freshwater using chloride mass balance: Proceedings of the Second Caribbean Islands Water-Resources Congress and Tropical Hydrology, May 5-8, 1985, American Water Resources Association, Technical Publication Series TPS-85-1, p. 50-55.

Wilson, H.M., 1899, Water resources of Puerto Rico: U.S. Geological Survey Water-Supply Paper 32.

Zack, A.L., 1985, Effects of sand removal on the Camuy Mangrove Forest, Puerto Rico: U.S. Geological Survey Water-Supply Paper 2254. 


\section{Ground Water--Continued}

Zack, A.L., 1988, A well system to recover usable water from a freshwater-saltwater aquifer in Puerto Rico: U.S. Geological Survey WaterSupply Paper 2328, 15 p.

Zack, A.L., and Class-Cacho, Angel, 1984, Restoration of freshwater in the Caño Tiburones area, Puerto Rico: U.S. Geological Survey WaterResources Investigations Report 83-4071, 33 p., 1 pl.

Zack, A.L., Rodríguez-Alonso, Teresita, and Román-Más, Angel, 1987, Puerto Rico ground-water quality - National Water Summary: U.S. Geological Survey Water-Supply Paper 2325, p. 437-442.

Zack, A.L., Rodríguez-Alonso, Teresita, and Román-Más, Angel, 1987, U.S. Virgin Islands ground-water quality - National Water Summary: U.S. Geological Survey Water-Supply Paper 2325, p. 489-492.

Zack, Allen, 1984, Use of scavenger-production well couples to optimize withdrawal of freshwater from saline aquifers in Puerto Rico: Proceedings of the First Caribbean Islands Water-Resources Congress, St. Thomas, U.S. Virgin Islands, July 26-27, 1984, p. 312-336.

Zack, Allen, 1986, Effects of sand removal on the shallow aquifer in the vicinity of the Camuy Mangrove Forest, Puerto Rico: in Quiñones, Ferdinand, Sánchez, A.V., and Smith, H.H., eds., Proceedings of the Third Caribbean Islands Water-Resources Congress, U.S. Virgin Islands, July 22-25, 1986, Puerto Rico Water Resources Association, p. 41-48.

Zack, Allen, and Román-Más, Angel, 1988, Hydrology of the Caribbean Islands Wetlands: Proceedings of the Caribbean Islands Wetlands Workshop, Forestry \& Wildlife Management Institute, University of Massachusetts at Amherst, October 28-29, 1986, p. 65-73.

\section{Ground-Water Level}

Colón-Ramos, Héctor, and Colón-Dieppa, Eloy, 1981, Ground-water levels and chloride concentrations in alluvial aquifers on the south coast of Puerto Rico, February 1980: U.S. Geological Survey Open-File Report 81-626, 20 p.

Dacosta, Rafael, and Gómez-Gómez, Fernando, 1987, Potentiometric surface of the alluvial aquifer and hydrologic conditions in the Guayama quadrangle, Puerto Rico, March 1986: U.S. Geological Survey Water-Resources Investigations Report 87-4162, 1 sheet.

Díaz, J.R., 1977, Ground-water levels in alluvium on the south coast of Puerto Rico, February 1977: U.S. Geological Survey Open-File Report 77696, $6 \mathrm{p}$.

Díaz, J.R., 1977, Ground-water levels on the south coast of Puerto Rico, February 1974 to February 1975: U.S. Geological Survey Open-File Report 76-625, 30 p.

Diaz, J.R., 1979, Ground-water levels in alluvium on the south coast of Puerto Rico, February 1978: U.S. Geological Survey Open-File Report 79$1272,18 \mathrm{p}$.

Graves, R.P., and González, Ralph, 1988, Potentiometric surface of the Turpentine Run basin aquifer in the Tutu area, eastern St. Thomas, U.S. Virgin Islands, September 11, 1987: U.S. Geological Survey Water-Resources Investigations Report 88-4131, 1 sheet.

Grossman, I.G., 1966, Fluctuations of ground-water levels in Puerto Rico resulting from earthquakes (1959-1961) [Abstract]: Transactions of the Third Caribbean Geological Conference, Kingston, Jamaica, April 1962, p. 104-105.

Heisel, J.E., and González, J.R., 1976, Ground-water levels on the south coast of Puerto Rico, February 1976: U.S. Geological Survey Open-File Report 76-705, 13 p.

Puig, J.C., and Rodríguez, J.M., 1990, Potentiometric surface of the alluvial aquifer and hydrologic conditions near Gurabo and Juncos, Puerto Rico, March 1988: U.S. Geological Survey Water-Resources Investigations Report 90-4059, 2 sheets.

Puig, J.C., Rodríguez-del-Río, Félix, and Rodriguez, J.M., 1989, Potentiometric surface of the alluvial aquifer and hydrologic conditions near Caguas, Puerto Rico, March 1988: U.S. Geological Survey Water-Resources Investigations Report 89-4075, 1 sheet.

Quiñones-Aponte, Vicente, and Gómez-Gómez, Fernando, 1987, Potentiometric surface of the alluvial aquifer and hydrologic conditions in the Salinas quadrangle, Puerto Rico, March 1986: U.S. Geological Survey Water-Resources Investigations Report 87-4161, 1 sheet.

Quiñones-Márquez, Ferdinand, 1981, Ground-water levels in the south coast of Puerto Rico, February 1969-71: U.S. Geological Survey OpenFile Data Report PR-1-71.

Ramos-Ginés, Orlando, 1991, Elevation of water table and hydrologic conditions in the Río Lapa to Río Majada area, Puerto Rico, for December 1988, and April, July, and October 1989: U.S. Geological Survey Water-Resources Investigations Report 90-4125, 4 p., 1 sheet. 


\section{Ground-Water Level--Continued}

Robison, T.M., 1971, Earthquake-accelerated decline of water level in an observation well in St. Thomas, Virgin Islands: U.S. Geological Survey Professional Paper 750-B, p. 252-253.

Rodríguez-del-Río, Félix, and Gómez-Gómez, Fernando, 1990, Potentiometric surface of the alluvial aquifer and hydrologic conditions in the Santa Isabel-Juana Díaz area, Puerto Rico, March to April 1987: U.S. Geological Survey Water-Resources Investigations Report 89-4116, 1 sheet.

Rodríguez-del-Río, Félix, and Quiñones-Aponte, Vicente, 1990, Potentiometric surface of the principal aquifer and hydrologic conditions in the Ponce-Juana Díaz area, Puerto Rico, April to May 1987: U.S. Geological Survey Water-Resources Investigations Report 89-41 15, 1 sheet.

Román-Más, Angel, and Ramos-Ginés, Orlando, 1987, Elevation of the water-table surface for the alluvial aquifer and hydrologic conditions in the Santa Isabel-Juana Díaz area, Puerto Rico, March 1986: U.S. Geological Survey Water-Resources Investigations Report 87-4123, 2 sheets.

Torres-González, Sigfredo, 1991, Compilation of ground-water level measurements obtained by the United States Geological Survey in Puerto Rico, 1958-1985: U.S. Geological Survey Open-File Data Report 88-701, 163 p.

Torres-González, Sigfredo, and Gómez-Gómez, Fernando, 1987, Potentiometric surface of the alluvial aquifer and hydrologic conditions in the Central Aguirre quadrangle, Puerto Rico, March 1986: U.S. Geological Survey Water-Resources Investigations Report 87-4160, 1 sheet.

Torres-González, Sigfredo, and Rodríguez-del-Río, Félix, 1990, Potentiometric surface of the Kingshill aquifer and hydrologic conditions, St. Croix, U.S. Virgin Islands, July 1987: U.S. Geological Survey Water-Resources Investigations Report 89-4085, 1 sheet.

Torres-Sierra, Heriberto, 1985, Potentiometric surface of the upper limestone aquifer in the Dorado-Vega Alta area, north-central Puerto Rico, February 1983: U.S. Geological Survey Water-Resources Investigations Report 85-4268, 1 sheet.

\section{Ground-Water Modeling}

Anders, R.B., 1971, Electric analog model study of water in the Yabucoa Valley, Puerto Rico (Phase-1, Collecting preliminary data and assembling available data): U.S. Geological Survey Open-File Report 71-5, $47 \mathrm{p}$.

Arroyo, I.E., Torres-González, Sigfredo, and Carrasquillo, R.A., 1990, A computer program for GEOphysical log data MANagement and plotting (GEOMAN): in Krishna, J.H., Quiñones-Aponte, Vicente, Gómez-Gómez, Fernando, and Morris, G.L., eds., Tropical Hydrology and Caribbean Water Resources, Proceedings of the International Symposium on Tropical Hydrology, San Juan, Puerto Rico, July 23-27, 1990, AWRA TPS-90-2, p. 395-401.

Bennett, G.D., 1976, Electrical analog simulation of the aquifers along the south coast of Puerto Rico: U.S. Geological Survey Open-File Report 74-4, $101 \mathrm{p}$.

Diaz, J.R., 1971, Electric analog model study of water in the Guayama area, Puerto Rico (Phase-1, Assembling data for the analog model): U.S. Geological Survey Open-File Report 71-86, 68 p.

Gómez-G6́mez, Fernando, and Torres-Sierra, Heriberto, 1988, Hydrology and effects of development on the water-table aquifer in the Vega Alta quadrangle, Puerto Rico: U.S. Geological Survey Water-Resources Investigations Report 87-4105, 54 p.

Heisel, J.E., González, J.R., and Cruz, Carlos, 1983, Analog model analysis of the north coast limestone aquifers, Puerto Rico: U.S. Geological Survey Open-File Report 82-52, 49 p.

Puig, J.C., Rolón-Collazo, L.I., and Pagán-Trinidad, Ismael*, 1990, Development of an aquifer management model: AQMAN3D: in Krishna, J.H., Quiñones-Aponte, Vicente, Gómez-Gómez, Fernando, and Morris, G.L., eds., Tropical Hydrology and Caribbean Water Resources, Proceedings of the International Symposium on Tropical Hydrology, San Juan, Puerto Rico, July 23-27, 1990, AWRA TPS-90-2, p. 39-48.

Quiñones-Aponte, Vicente, 1986, Simulation of ground-water flow in the Río Yauco alluvial valley, Yauco, Puerto Rico: U.S. Geological Survey Water-Resources Investigations Report 85-4179, 32 p.

Quiñones-Aponte, Vicente, and Torres-Sierra, Heriberto, 1985, Application of a ground-water flow digital model in evaluating alternate dewatering systems in the Río Grande de Arecibo alluvial valley, Puerto Rico: Proceedings of the Tropical Hydrology and Second Caribbean Islands Water-Resources Congress, May 5-8, 1985, American Water Resources Association, Technical Publication Series TPS-85-1, p. 129134.

Robison, T.M., and Anders, R.B., 1973, Electric analog model study of the alluvial aquifer in the Yabucoa Valley, Puerto Rico (Phase 2--The planning, construction, and use of the model): U.S. Geological Survey Open-File Report 73-242, 47 p.

Sepúlveda, Nicasio, 1991, Solution of the one-dimensional consolidation theory equation with a Pseudospectral Method: Proceedings of the Fourth International Association of Hydrological Sciences, Symposium on Land Subsidence, Houston, Texas, 1AHS no. 200 , p. 555-564. 


\section{Ground-Water Modeling--Continued}

Sépulveda, Nicasio, 1992, Computer algorithm for the analysis of underdamped and overdamped water-level responses in slug tests: U.S. Geological Survey Water Resources-Investigations Report 91-4162, 20 p.

Sepulveda, Nicasio, and Zack, A.L., 1990, Laboratory simulation of the effects of overburden stress on the specific storage of shallow artesian aquifers: in Krishna, J.H., Quiñones-Aponte, Vicente, Gómez-Gómez, Fernando, and Morris, G.L., eds., Tropical Hydrology and Caribbean Water Resources, Proceedings of the International Symposium on Tropical Hydrology, San Juan, Puerto Rico, July 23-27, 1990, AWRA TPS-90-2, p. 349-356.

Torres-González, Arturo, 1985, Simulation of ground-water flow in the water table aquifer near Barceloneta, Puerto Rico: U.S. Geological Survey Water-Resources Investigations Report 84-4113, 39 p.

Torres-González, Sigfredo, 1991, Steady-state simulation of ground-water flow conditions in the Kingshill aquifer, St. Croix, U.S. Virgin Islands, July 1987: in Gómez-Gómez, Fernando, Quiñones-Aponte, Vicente, and Johnson, A.I., eds., Aquifers of the Caribbean Islands, Proceedings of the International Symposium on Tropical Hydrology, San Juan, Puerto Rico, July 23-27, 1990, AWRA Monograph Series no. 15, p. 93-108.

Torres-González, Sigfredo, and Rolón-Collazo, L.I., 1990, The interactive computer program MODUMANAG, a data management tool for the modular finite-difference ground-water flow model: in Krishna, J.H., Quiñones-Aponte, Vicente, Gómez-Gómez, Fernando, and Morris, G.L., eds., Tropical Hydrology and Caribbean Water Resources, Proceedings of the International Symposium on Tropical Hydrology, San Juan, Puerto Rico, July 23-27, 1990, AWRA TPS-90-2, p. 403-410.

Troester, J.W., Deike, R.G., Robinson, P.D.*, and Collar, P.D., 1990, Petrographic analyses and geochemical modeling of aquequs/solid phase reactions in the Valle de Yabucoa alluvial aquifer, Puerto Rico [Abstract]: The Geological Society of America, Abstracts with Programs, p. A295.

\section{Sediment}

Collar, P.D., 1991, Fluvial metal transport during a storm event, Río Grande de Loíza basin, Puerto Rico [Abstract]: The Geological Society of America, Abstracts with Programs, v. 23, no. 5, p. 203.

Collar, P.D., and Guzmán-Ríos, Senén, 1991, Sedimentation rates and capacity restoration options, Lago Loíza, Puerto Rico: in Drs. Shou-Shan Fan and Yung-Huang Kuo, eds., Proceedings of the Fifth Federal Interagency Sedimentation Conference, Las Vegas, Nevada, March 18-21, 1991 , v. 2 , p. $15-17$ to $15-25$.

Ellis, S.R., 1976, History of dredging and filling of lagoons in the San Juan area, Puerto Rico: U.S. Geological Survey Water-Resources Investigations Report 76-38, 25 p., 4 pls.

Figueroa-Alamo, Carlos, 1991, Sedimentation survey of Lago Toa Vaca, Puerto Rico, July 1985: U.S. Geological Survey Open-File Report 90$199,9 \mathrm{p}$.

Gellis, Allen, 1990, Sediment loads in selected streams in Puerto Rico during the passage of Hurricane Hugo [Abstract]: The Geological Society of America, Abstracts with Programs, v. 22, no. 7, p. A331.

Gellis, Allen, 1991, Construction effects on sediment for two basins in Puerto Rico: in Drs. Shou-Shan Fan and Yung-Huang Kuo, eds., Proceedings of the Fifth Federal Interagency Sedimentation Conference, Las Vegas, Nevada, March 18-21, 1991 , v. 1, p. 4-72 to 4-78.

Guzmán-Ríos, Senén, 1989, Suspended-sediment data in the upper Río Grande de Loíza basin, Puerto Rico: U.S. Geological Survey Open-File Data Report 88-324, 42 p.

Harris, K.F., 1962, Inventory of published and unpublished sediment-load data, United States and Puerto Rico, 1950-60: U.S. Geological Survey Water-Supply Paper 1547, 117 p.

Quiñones, Ferdinand, Green, Bruce, and Santiago, Luis, 1989, Sedimentation survey of Lago Loíza, Puerto Rico, July 1985: U.S. Geological Survey Water-Resources Investigations Report 87-4019, 17 p.

Quiñones, Ferdinand, Meléndez, Frank, and Bonnet, Carlos, 1989, Sedimentation survey of Lago Dos Bocas, Puerto Rico, June 1985: U.S. Geological Survey Open-File Report 86-241, 14 p. 


\section{Surface Water}

Adolphson, D.G., Seijo, M.A., and Robison, T.M., 1977, Water resources of the Maunabo Valley, Puerto Rico: U.S. Geological Survey WaterResources Investigations Report 115-76, 38 p.

Anders, R.B., 1968, Reconnaissance of the water resources of the Central Guanajibo Valley, Cabo Rojo, Puerto Rico: U.S. Geological Survey Open-File Report, 15 p.

Arnow, Ted, and Bogart, D.B., 1959, Water problems of Puerto Rico and a program of water-resources investigations: Transactions of the Second Caribbean Geological Conference, January 4-9, 1959, Mayagdez, Puerto Rico, p. 120-129.

Barnes, H.H., Jr., and Bogart, D.B., 1961, Floods of September 6, 1960, in eastern Puerto Rico: U.S. Geological Survey Circular 451, 13 p.

Bennett, G.D., 1972, Ground water along Río Bucaná at Ponce, Puerto Rico - And the effects of a proposed floodway on ground-water quality: U.S. Geological Survey Water-Resources Bulletin 11, 29 p.

Bogart, D.B., Arnow, Ted, and Crooks, J.W., 1960, Water problems of Puerto Rico and a program of water-resources investigations: U.S. Geological Survey Water-Resources Bulletin 1, 40 p.

Bogart, D.B., Arnow, Ted, and Crooks, J.W., 1964, Water resources of Puerto Rico - A progress report: U.S. Geological Survey WaterResources Bulletin 4, 120 p.

Cobb, E.D., 1978, Estimates of 7-day, 10-year minimum flows at selected stream sites in Puerto Rico: U.S. Geological Survey Open-File Report 78-583, $19 \mathrm{p}$.

Collar, P.D., 1991, Fluvial metal transport during a storm event, Río Grande de Loíza basin, Puerto Rico [Abstract]: The Geological Society of America, Abstracts with Programs, v. 23, no. 5, p. 203.

Collar, P.D., and Guzmán-Ríos, Senén, 1991, Sedimentation rates and capacity restoration options, Lago Loíza, Puerto Rico: in Drs. Shou-Shan Fan and Yung-Huang Kuo, eds., Proceedings of the Fifth Federal Interagency Sedimentation Conference, Las Vegas, Nevada, March 18-21, 1991 , v. 2, p. $15-17$ to $15-25$.

Colón-Dieppa, Eloy, 1986, Puerto Rico surface-water resources - National Water Summary 1985: U.S. Geological Survey Water-Supply Paper 2300 , p. $399-406$.

Colón-Dieppa, Eloy, and González, Ralph, 1978, Cross section data for selected Puerto Rico streams: U.S. Geological Survey Open-File Report $78-882,153 \mathrm{p}$.

Colón-Dieppa, Eloy, and Mansue, L.J., 1976, Water resources of the proposed copper mining area, Puerto Rico, $1958-74$ (2 Parts): U.S. Geological Survey Open-File Report 76-1 and 76-2, 414 p.

Colón-Dieppa, Eloy, and Quiñones-Aponte, Vicente, 1985, Estimates of 7-day, 10-year low flow at ungaged streams in Puerto Rico: U.S. Geological Survey Water-Resources Investigations Report 84-4089, 2 sheets.

Colón-Dieppa, Eloy, and Quiñones-Márquez, Ferdinand, 1985, A reconnaissance of the water resources of the Central Río Guanajibo Valley, Puerto Rico: U.S. Geological Survey Water-Resources Investigations Report 82-4050, 47 p.

Colón-Dieppa, Eloy, and Torres-Sierra, Heriberto, 1991, Puerto Rico floods and droughts - National Water Summary 1988-89: U.S. Geological Survey Water-Supply Paper 2375, p. 475-482.

Colón-Dieppa, Eloy, Díaz, P.L., and García, René, 1987, Water resources data Puerto Rico and the U.S. Virgin Islands, Water Year 1985: U.S. Geological Survey Water-Data Report PR-85-1, 400 p.

Colón-Dieppa, Eloy, Torres-Sierra, Heriberto, and Ortíz, Jorge, 1991, U.S. Virgin Islands floods and droughts - National Water Summary 1988-89: U.S. Geological Survey Water-Supply Paper 2375, p. 521-526.

Cosner, O.J., 1972, Water in St. John, U.S. Virgin Islands: U.S. Geological Survey Open-File Report 72-78, 46 p.

Curtis, R.E., Jr., 1984, Floods of April 18, 1983 on St. Thomas and St. John, U.S. Virgin Islands: U.S. Geological Survey Water-Resources Investigations Report 84-4184, 1 sheet.

Curtis, R.E., Jr., 1985, Floods of April 18, 1983 on St. Thomas and St. John, U.S. Virgin Islands: Proceedings of the Tropical Hydrology and Second Caribbean Islands Water-Resources Congress, May 5-8, 1985, American Water Resources Association, Technical Publication Series TPS-85-1, p. 90-95.

Curtis, R.E., Jr., Guzmán-Ríos, Senén, and Díaz, P.L., 1984, Water resources data Puerto Rico and the U.S. Virgin Islands, Water Year 1983: U.S. Geological Survey Water-Data Report PR-83-1, 302 p. 


\section{Surface Water--Continued}

Curtis, R.E., Jr., Guzmán-Ríos, Senén, and Díaz, P.L., 1985, Water resources data Puerto Rico and the U.S. Virgin Islands, Water Year 1984: U.S. Geological Survey Water-Data Report PR-84-1, 374 p.

Curtis, R.E., Jr., McKinley P.W., and Colón-Ramos, H.M., 1983, Water resources data Puerto Rico, Water Years 1981-82: U.S. Geological Survey Water-Data Report PR-81-82-1, 414 p.

Curtis, R.E., Jr., Aquino, Zaida, Díaz, P.L., and García, René, 1988, Water resources data Puerto Rico and the U.S. Virgin Islands, Water Year 1986: U.S. Geological Survey Water-Data Report PR-86-1,362 p.

Curtis, R.E., Jr., Aquino, Zaida, Díaz, P.L., and Vachier, Ricardo, 1989, Water resources data Puerto Rico and the U.S. Virgin Islands, Water Year 1987: U.S. Geological Survey Water-Data Report PR-87-1, 356 p.

Curtis, R.E., Jr., Aquino, Zaida, Díaz, P.L., and Vachier, Ricardo, 1989, Water resources data Puerto Rico and the U.S. Virgin Islands, Water Year 1988: U.S. Geological Survey Water-Data Report PR-88-1, 460 p.

Curtis, R.E., Jr., Aquino, Zaida, Díaz, P.L., and Vachier, Ricardo, 1990, Water resources data Puerto Rico and the U.S. Virgin Islands, Water Year 1989: U.S. Geological Survey Water-Data Report PR-89-1, 419 p.

Curtis, R.E., Jr., Aquino, Zaida, Díaz, P.L., and Vachier, Ricardo, 1991, Water resources data Puerto Rico and the U.S. Virgin Islands, Water Year 1990: U.S. Geological Survey Water-Data Report PR-90-1, 514 p.

Díaz, J.R., 1971, Electric analog model study of water in the Guayama area, Puerto Rico (Phase-1, Assembling data for the analog model): U.S. Geological Survey Open-File Report 71-86, 68 p.

Díaz, J.R., 1973, Chemical quality of water in Caño Tiburones, Puerto Rico: A reconnaissance study carried out in 1967: U.S. Geological Survey Open-File Report Map Series no. 2, 2 pls.

Díaz, J.R., and Jordan, D.G., 1987, Water resources of the Río Grande de Añasco - lower Valley, Puerto Rico: U.S. Geological Survey WaterResources Investigations Report 85-4237, 48 p.

Durfor, C.N., and Becker, Edith, 1964, Chemical quality of public water supplies of the United States and Puerto Rico, 1962: U.S. Geological Survey Hydrologic Investigations Atlas HA-200, 1 sheet.

Durum, W.H., Hem, J.D., and Heidel, S.G., 1971, Reconnaissance of selected minor elements in surface waters of the United States, October 1970: U.S. Geological Survey Circular 643, 49 p.

Elhins, K.K., Román-Más, Angel, and Lee, R.N., 1986, Estimating ground-water influx to a portion of the Río Grande de Manatí River basin in Puerto Rico through the measurement of ${ }^{222} \mathrm{Rn}$ : in Quiñones, Ferdinand, Sánchez, A.V., and Smith, H.H., eds., Proceedings of the Third Caribbean Islands Water-Resources Congress, U.S. Virgin Islands, July 22-25, 1986, Puerto Rico Water Resources Association, p. 27.

Ellis, S.R., 1976, History of dredging and filling of lagoons in the San Juan area, Puerto Rico: U.S. Geological Survey Water-Resources Investigations Report 76-38, 25 p., 4 pls.

Ellis, S.R., and Gómez-Gómez, Fernando, 1975, Water-quality and hydraulic data, San Juan lagoon system, Puerto Rico: U.S. Geological Survey Open-File Report 75-2-PR, 142 p.

Ellis, S.R., and Gómez-Gómez, Fernando, 1976, Hydrologic characteristics of lagoons at San Juan, Puerto Rico, during a January 1974 tidal cycle: U.S. Geological Survey Water-Resources Investigations Report 75-38, 45 p.

Fields, F.K., 1971, Floods in the Añasco area, Puerto Rico: U.S. Geological Survey Hydrologic Investigations Atlas HA-375, 1 sheet.

Fields, F.K., 1971, Floods in the Guayanilla-Yauco area, Puerto Rico: U.S. Geological Survey Hydrologic Investigations Atlas HA-414, 1 sheet.

Fields, F.K., 1971, Floods in the Yabucoa area, Puerto Rico: U.S. Geological Survey Hydrologic Investigations Atlas HA-382, 1 sheet.

Fields, F.K., 1972, Floods at Caguas, Gurabo, Juncos, and San Lorenzo, Puerto Rico: U.S. Geological Survey Hydrologic Investigations Atlas HA-438, 1 sheet.

Figueroa-Alamo, Carlos, 1991, Sedimentation survey of Lago Toa Vaca, Puerto Rico, July 1985: U.S. Geological Survey Open-File Report 90$199,9 \mathrm{p}$.

Gellis, Allen, 1990, Sediment loads in selected streams in Puerto Rico during the passage of Hurricane Hugo [Abstract]: The Geological Society of America, Abstracts with Programs, v. 22, no. 7, p. A331.

Gellis, Allen, 1991, Construction effects on sediment for two basins in Puerto Rico: in Drs. Shou-Shan Fan and Yung-Huang Kuo, eds., Proceedings of the Fifth Federal Interagency Sedimentation Conference, Las Vegas, Nevada, March 18-21, 1991, v. 1, p. 4-72 to 4-78. 


\section{Surface Water--Continued}

Giusti, E.V., 1968, Water resources of the Juana Díaz area, Puerto Rico - A preliminary appraisal, 1966: U.S. Geological Survey WaterResources Bulletin 8, 43 p.

Giusti, E.V., 1971, Regional specific yield of the Coamo Fan, Puerto Rico, computed by the water budget method: in Geological Survey Research 1971, Chap. B, U.S. Geological Survey Professional Paper 750-B, p. 248-251.

Giusti, E.V., 1971, Water resources of the Coamo area, Puerto Rico: U.S. Geological Survey Water-Resources Bulletin 9, 31 p.

Giusti, E.V., and Bennett, G.D., 1976, Water resources of the north coast limestone area, Puerto Rico: U.S. Geological Survey Water-Resources Investigations Report 75-42, $42 \mathrm{p}$

Giusti, E.V., and López, M.A., 1967, Climate and streamflow of Puerto Rico: Caribbean Journal of Science, September - December, 1967, v. 7, no. $3-4$, p. 87-93.

Gómez-Gómez, Fernando, 1979, Reconnaissance of six solid-waste disposal sites in Puerto Rico and effects on water quality: U.S. Geological Survey Open-File Report 79-1338, 73 p.

Gómez-Gómez, Fernando, 1984, Water resources of the lower Río Grande de Manatí Valley: U.S. Geological Survey Water-Resources Investigations Report 83-4199, 42 p.

Gómez-Gómez, Fernando, 1986, Caribbean Islands Regional Aquifer-System Study - Phase 1, Regional Aquifer-System Study projects started in 1984: in Ren Jen Sun, ed., Summary of Projects 1978-84: U.S. Geological Survey Circular 1002, p. $234-241$.

Gómez-Gómez, Fernando, 1987, Planning report for the Caribbean Islands Regional Aquifer-System Analysis project: U.S. Geological Survey Water-Resources Investigations Report 86-4074, 50 p., 3 pls.

Gómez-Gómez, Fernando, 1990, Hydrochemistry of the South Coastal Plain Aquifer System of Puerto Rico and its relation to surface-water recharge: in Gómez-Gómez, Fernando, Quiñones-Aponte, Vicente, and Johnson, A.I., eds., Aquifers of the Caribbean Islands, Proceedings of the International Symposium on Tropical Hydrology, San Juan, Puerto Rico, July 23-27, 1990, AWRA Monograph Series no. 15, p. 57-75.

Gómez-Gómez, Fernando, Quiñones, Ferdinand, and Ellis, S.R., 1983, Hydrologic characteristics of lagoons at San Juan, Puerto Rico, during an October 1974 tidal cycle: U.S. Geological Survey Open-File Report 82-349, 34 p.

Gómez-Gómez, Fernando, Quiñones, Ferdinand, and López, Marisol, 1984, Public water supplies in Puerto Rico, 1983: U.S. Geological Survey Open-File Data Report 84-126, 102 p.

Graves, R.P., 1989, Water resources of the Humacao-Naguabo area, eastern Puerto Rico: U.S. Geological Survey Water-Resources Investigations Report 87-4088, 69 p.

Graves, R.P., 1991, Ground-water resources in Lajas Valley, Puerto Rico: U.S. Geological Survey Water-Resources Investigations Report 894182, $55 \mathrm{p}$.

Grossman, I.G., Bogart, D.B., Crooks, J.W., and Díaz, J.R., 1972, Water resources of the Tallaboa Valley, Puerto Rico: U.S. Geological Survey Water-Resources Bulletin 7, 115 p.

Guzmán-Ríos, Senén, 1989, Suspended-sediment data in the upper Río Grande de Loíza basin, Puerto Rico: U.S. Geological Survey Open-File Data Report 88-324, 42 p.

Haire, W.J., 1971, Flooding along the Río Piedras in the San Juan area, Puerto Rico: U.S. Geological Survey Hydrologic Investigations Map Series no. 1, 2 sheets.

Haire, W.J., 1971, Floods in Salinas area, Puerto Rico: U.S. Geological Survey Hydrologic Investigations Atlas HA-447, 1 sheet.

Haire, W.J., 1971, Floods in the Guayama area, Puerto Rico: U.S. Geological Survey Hydrologic Investigations Atlas HA-446, 1 sheet.

Haire, W.J., 1971, Floods in the Patillas-Maunabo area, Puerto Rico: U.S. Geological Survey Hydrologic Investigations Atlas HA-445, 1 sheet.

Haire, W.J., 1971, Floods in the Santa Isabel area, Puerto Rico: U.S. Geological Survey Hydrologic Investigations Atlas HA-448, 1 sheet.

Haire, W.J., 1972, Flood of October 5-10, 1970 in Puerto Rico: U.S. Geological Survey Water-Resources Bulletin 12, 38 p.

Haire, W.J., 1972, Floods in the Río Guanajibo Valley, southwestern Puerto Rico: U.S. Geological Survey Hydrologic Investigations Atlas HA456, 1 sheet.

Haire, W.J., 1975, Floods in the Carolina-Río Grande area, northeastern Puerto Rico: U.S. Geological Survey Hydrologic Investigations Atlas HA-533, 1 sheet. 


\section{Surface Water--Continued}

Haire, W.J., 1975, Floods in the Fajardo-Luquillo area, northeastern Puerto Rico: U.S. Geological Survey Hydrologic Investigations Atlas HA545,1 sheet.

Haire, W.J., 1978, Floods in the Naguabo area, eastern Puerto Rico: U.S. Geological Survey Hydrologic Investigations Atlas HA-584, 1 sheet.

Haire, W.J., and Johnson, K.G., 1973, Floods in and near the Charlotte Amalie area, St. Thomas, U.S. Virgin Islands: U.S. Geological Survey Hydrologic Investigations Map Series no. 3, 4 sheets.

Haire, W.J., and Johnson, K.G., 1977, Floods of November 12, 1974, in the Charlotte Amalie area, St. Thomas, U.S. Virgin Islands: U.S. Geological Survey Water-Resources Investigations Report 76-91, 3 sheets.

Haire, W.J., and Johnson, K.G., 1978, Floods of November 11-13, 1974, in St. Croix, U.S. Virgin Islands: U.S. Geological Survey WaterResources Investigations Report 77-136, 11 sheets.

Harris, K.F., 1962, Inventory of published and unpublished sediment-load data, United States and Puerto Rico, 1950-60: U.S. Geological Survey Water-Supply Paper 1547, 117 p.

Heisel, J.E., and González, J.R., 1976, Ground-water levels on the south coast of Puerto Rico, February 1976: U.S. Geological Survey Open-File Report 76-705, 13 p.

Hickenlooper, I.J., 1967, Floods at Barceloneta and Manatí, Puerto Rico: U.S. Geological Survey Hydrologic Investigations Atlas HA-262, 1 sheet.

Hickenlooper, I.J., 1968, Floods at Arecibo, Puerto Rico: U.S. Geological Survey Hydrologic Investigations Atlas HA-271, 1 sheet.

Hickenlooper, I.J., 1968, Flo is in the area of Vega Aita and Vega Baja, Puerto Rico: U.S. Geological Survey Hydrologic Investigations Atlas HA-289, 1 sheet.

Hickenlooper, I.J., 1968, Floods in the Mayagüez area of Puerto Rico: U.S. Geological Survey Hydrologic Investigations Atlas HA-288, 1 sheet.

Hickenlooper, I.J., and López, M.A., 1967, Floods in the Ponce area, Puerto Rico: U.S. Geological Survey Hydrologic Investigations Atlas HA-261, 1 sheet.

Johnson, K.G., 1972, Floods in the Aguadilla-Aguada area, northwestern Puerto Rico: U.S. Geological Survey Hydrologic Investigations Atlas HA-457, 1 sheet.

Johnson, K.G., 1974, Floods in eastern Lajas Valley and the lower Río Loco basin, southwestern Puerto Rico: U.S. Geological Survey Hydrologic Investigations Atlas HA-532, 1 shcet.

Johnson, K.G., 1981, Flood of September 16, 1975, in Tallaboa Valley, Puerto Rico: U.S. Geological Survey Water-Resources Investigations Open-File Report 80-1283, 5 sheets.

Johnson, K.G., 1982, Flood of September 16, 1975, in the Guanajibo Valley, Puerto Rico: U.S. Geological Survey Water-Resources Investigations Open-File Report 81-805, 1 sheet.

Johnson, K.G., 1982, Flood of September 16, 1975, in the Guayanilla Valley, Puerto Rico: U.S. Geological Survey Water-Resources Investigations Open-File Report 80-1282, 1 sheet.

Johnson, K.G., 1982, Flood of September 16, 1975, in the Yauco Valley, Puerto Rico: U.S. Geological Survey Open-File Report 81-331, 13 p.

Johnson, K.G., and Carrasquillo, R.A., 1982, Floods of October 9, 1970, and September 16, 1975, at Jayuya, Puerto Rico: U.S. Geological Survey Water-Resources Investigations Open-File Report 81-346, 1 sheet.

Johnson, K.G., and González, Ralph, 1982, Flood of September 16, 1975, in the Guánica area, Puerto Rico: U.S. Geological Survey Open-File Report 81-480, 1 sheet.

Johnson, K.G., and Quiñones-Aponte, Vicente, 1982, Flood of September 16, 1975, in the Añasco area, Puerto Rico: U.S. Geological Survey Water-Resources Investigations Open-File Report 81-345, 1 sheet.

Johnson, K.G., Carrasquillo, R.A., and González, Ralph, 1982, Flood of October 8, 1977, in St. Croix, U.S. Virgin Islands: U.S. Geological Survey Water-Resources Investigations Open-File Report 82-262, 21 p., 3 pls.

Johnson, K.G., Quiñones, Ferdinand, and Alicea, José, 1982, Flood of September 16, 1975, at Utuado, Puerto Rico: U.S. Geological Survey Water-Resources Investigations Open-File Report 81-413, 1 sheet. 


\section{Surface Water--Continued}

Johnson, K.G., Quiñones, Ferdinand, and González, Ralph, 1987, Hydraulic analyses of water-surface profiles in the vicinity of the Coamo Dam and Highway 52 bridge, southern Puerto Rico; Flood analyses as related to the flood of October 7, 1985: U.S. Geological Survey WaterResources Investigations Report 87-4039, 26 p.

Jordan, D.G., 1970, Water and copper-mine tailings in karst terrane of Río Tanamá basin, Puerto Rico: U.S. Geological Survey Open-File Report $71-163,24 \mathrm{p}$.

Jordan, D.G., 1972, Land-use effect on the water regimen of the U.S. Virgin Islands: in Geological Survey Research 1972, Chap. D, U.S. Geological Survey Professional Paper 800-D, p. 211-216.

Jordan, D.G., 1975, A survey of the water resources of St. Croix, Virgin Islands: U.S. Geological Survey Open-File Report 73-137, 51 p.

Jordan, D.G., and Cosner, O.J., 1973, A survey of the water resources of St. Thomas, Virgin Islands: U.S. Geological Survey Open-File Report $72-201,55 \mathrm{p}$.

Jordan, D.G., and Gilbert, B.K., 1976, Water supply and waste disposal, Culebra, Puerto Rico: U.S. Geological Survey Water-Resources Investigations $76-3,31 \mathrm{p}$.

Kipple, F.P., and others, 1968, Water records of Puerto Rico, 1958-63: U.S. Geological Survey Water-Data Report, 353 p.

Lohr, E.W., 1957, Chemical character of public water supplies of the larger cities in Alaska, Hawaii, and Puerto Rico, 1954: U.S. Geological Survey Water-Supply Paper 1460-A, 39 p., 1 pl.

López, M.A., 1962, Floods at Bayamón and Cataño, Puerto Rico: U.S. Geological Survey Hydrologic Investigations Atlas HA-77, 1 sheet.

López, M.A., 1964, Floods at Toa Alta, Toa Baja, and Dorado, Puerto Rico: U.S. Geological Survey Hydrologic Investigations Atlas HA-128, 1 sheet.

López, M.A., 1967, Floods at Humacao, Puerto Rico: U.S. Geological Survey Hydrologic Investigations Atlas HA-265, 1 sheet.

López, M.A., and Fields, F.K., 1970, A proposed streamflow-data program for Puerto Rico: U.S. Geological Survey Open-File Report, 42 p.

López, M.A., Colón-Dieppa, Eloy, and Cobb, E.D., 1979, Floods in Puerto Rico, magnitude and frequency: U.S. Geological Survey WaterResources Investigations Report 78-141, 68 p.

McClymonds, N.E., 1967, Water resources of the Guánica area, Puerto Rico - A preliminary appraisal, 1963: U.S. Geological Survey WaterResources Bulletin 6, 43 p.

McClymonds, N.E., 1972, Water resources of the Ponce area, Puerto Rico: U.S. Geological Survey Water-Resources Bulletin 14, 26 p.

McClymonds, N.E., and Díaz, J.R., 1972, Water resources of the Jobos area, Puerto Rico - A preliminary appraisal, 1962: U.S. Geological Survey Water-Resources Bulletin 13, 32 p.

McClymonds, N.E., and Ward, P.E., 1966, Hydrologic characteristics of the alluvial fan near Salinas, Puerto Rico: in Geological Survey Research 1966, Chap. C, U.S. Geological Survey Professional Paper 550-C, p. 231-234.

McCoy, J.H., 1978, Summary of the water resources of Puerto Rico: U.S. Geological Survey Open-File Report 78-971, 24 p.

McGuinness, C.L., 1953, Summary of the water resources of the Virgin Islands: U.S. Geological Survey Open-File Report, 8 p.

McKinley, P.W., 1985, Surface water data network analysis for Puerto Rico: U.S. Geological Survey Water-Resources Investigations Report $83-4055,14 \mathrm{p}$.

Menoyo, L.E., 1992, Using a microcomputer to create an animated three-dimensional visualization of Bahía de Añasco, Puerto Rico [Abstract]: Joint U.S. Geological Survey/Jet Propulsion Laboratory Scientific Visualization Workshop, Program and Abstracts, Norfolk, Virginia, May 1819, 1992, p. 22.

Puig, J.C., and Rodríguez, J.M., 1992, Ground-water resources of the Caguas-Juncos Valley, Puerto Rico: U.S. Geological Survey WaterResources Investigations Report 91-4079, 48 p.

Quiñones, Ferdinand, and Alicea, José, 1981, Water resources investigations in Puerto Rico and the U.S. Virgin Islands - Programs and activities of the U.S. Geological Survey, Water Resources Division, Caribbean District: U.S. Geological Survey Open-File Report, 69 p.

Quiñones, Ferdinand, and Alicea, José, 1983, Water resources investigations in Puerto Rico and the U.S. Virgin Islands - Programs and activities of the U.S. Geological Survey, Water Resources Division, Caribbean District: U.S. Geological Survey Open-File Report, 28 p. 


\section{Surface Water--Continued}

Quiñones, Ferdinand, and Alicea, José, 1984, Water resources investigations in Puerto Rico and the U.S. Virgin Islands - Programs and activities of the U.S. Geological Survey, Water Resources Division, Caribbean District: U.S. Geological Survey Open-File Report, 41 p.

Quiñones, Ferdinand, and Johnson, K.G., 1987, The floods of May 17-18, 1985, and October 6-7, 1985, in Puerto Rico: U.S. Geological Survey Open-File Report 87-123, 22 p.

Quiñones, Ferdinand, Colón-Dieppa, Eloy, and Juarbe, Max, 1984, Flow duration at streamflow gaging stations in Puerto Rico: U.S. Geological Survey Open-File Data Report 84-127, 93 p.

Quiñones, Ferdinand, Green, Bruce, and Santiago, Luis, 1989, Sedimentation survey of Lago Loíza, Puerto Rico, July 1985: U.S. Geological Survey Water-Resources Investigations Report 87-4019, 17 p.

Quiñones, Ferdinand, Meléndez, Frank, and Bonnet, CarIos, 1989, Sedimentation survey of Lago Dos Bocas, Puerto Rico, June 1985: U.S. Geological Survey Open-File Report 86-241, 14 p.

Quiñones-Aponte, Vicente, 1986, Water resources of the lower Río Grande de Arecibo alluvial valley, Puerto Rico: U.S. Geological Survey Water-Resources Investigations Report 85-4160, 38 p., 1 pl.

Quiñones-Aponte, Vicente, 1987, Effects of the channelization of Río Bucaná on the ground-water resources north of the Ponce Valley, Puerto Rico; Numerical analysis: Proceedings of the 12th Natural Resources Symposium, San Juan, Puerto Rico, December 11-12, 1985, Puerto Rico Department of Natural Resources (Published in Spanish), 4 p.

Quiñones-Aponte, Vicente, 1989, Hydrogeologic characteristics of the lower Río Grande de Arecibo alluvial valley: Proceedings of the 13th Natural Resources Symposium, San Juan, Puerto Rico, February 26, 1987, Puerto Rico Department of Natural Resources, p. 41-59.

Quiñones-Aponte, Vicente, 1991, Water-resources development and its influence on the water budget for the aquifer system in the Salinas to Patillas area, Puerto Rico: in Gómez-Gómez, Fernando, Quiñones-Aponte, Vicente, and Johnson, A.I., eds., Aquifers of the Caribbean Islands, Proceedings of the International Symposium on Tropical Hydrology, San Juan, Puerto Rico, July 23-27, 1990, AWRA Monograph Series no. 15, p. $37-55$.

Quiñones-Márquez, Ferdinand, 1973, Chemical-quality and flow-duration curves for selected streams in Puerto Rico: U.S. Geological Survey Open-File Report PR-7.

Quiñones-Márquez, Ferdinand, 1975, Chemical, biochemical, and bacteriological determinations at selected stream sites in Puerto Rico: U.S. Geological Survey Open-File Report 75-1,118 p.

Quiñones-Márquez, Ferdinand, 1976, Chemical, physical, biochemical, and bacteriological determinations in Lago Loíza, Puerto Rico, and in its main tributaries, September 1973 - December 1974: U.S. Geological Survey Open-File Report 76-7, 74 p.

Quiñones-Márquez, Ferdinand, 1976, Chemical, physical, biochemical, and bacteriological determinations in Laguna Tortuguero, Puerto Rico, July 1974 - June 1975: U.S. Geological Survey Open-File Report 76-5, 39 p.

Quiñones-Márquez, Ferdinand, 1980, Limnology of Lago Loíza, Puerto Rico: U.S. Geological Survey Water-Resources Investigations Report 79-97, $113 \mathrm{p}$.

Quiñones-Márquez, Ferdinand, 1981, Frecuencia de magnitud y flujos en los ríos principales de Puerto Rico: U.S. Geological Survey Open-File Data Report.

Quiñones-Márquez, Ferdinand, 1987, Management and development of surface and ground water: in Krushesky, R.D., ed., Proceedings of the Development of Mineral, Energy, and Water Resources and Mitigation of Geologic Hazards in Central America, U.S. Geological Survey Circular 1006, p. 140-149.

Quiñones-Márquez, Ferdinand, and Fusté, L.A., 1978, Limnology of Laguna Tortuguero, Puerto Rico: U.S. Geological Survey WaterResources Investigations Report 77-122, 86 p.

Quiñones-Márquez, Ferdinand, and Peña-Cruz, Gilberto, 1985, Water resources investigations in Puerto Rico and the U.S. Virgin Islands Programs and activities of the U.S. Geological Survey, Water Resources Division, Caribbean District 1984-1985: U.S. Geological Survey Open-File Report 85-556, 43 p.

Quiñones-Márquez, Ferdinand, Guzmán-Ríos, Senén, 1986, Determinación de caudal y técnicas de muestreo en agua superficial: U.S. Geological Survey Water-Resources Investigations Report 85-89, 68 p.

Quiñones-Márquez, Ferdinand, López, M.A., and Latkovich, V.J., 1976, Water records of the Río Piedras basin, Puerto Rico, 1971-74: U.S. Geological Survey Open-File Report 76-3, 111 p. 


\section{Surface Water--Continued}

Quiñones-Márquez, Ferdinand, Vázquez, Pedro, and Peña, Rafael, 1977, Chemical, physical, biochemical, and bacteriological characteristics at selected stream sites in Puerto Rico, 1975-76: U.S. Geological Survey Open-File Report 77-237, 176 p.

Quiñones-Márquez, Ferdinand, Vázquez, Pedro, and Peña-Cortés, Rafael, 1978, Chemical, physical, biochemical, and bacteriological characteristics at selected stream sites in Puerto Rico 1976-77: U.S. Geological Survey Open-File Report 78-445, 145 p.

Quiñones-Márquez, Ferdinand, Vázquez, Pedro, Class, Angel, and Peña, Rafael, 1976, Chemical, physical, biochemical, and bacteriological characteristics at selected stream sites in Puerto Rico, 1974-75: U.S. Geological Survey Open-File Report 76-1, 163 p.

Reid, Ken, 1991, Cost-effectiveness of the stream-gaging program in Puerto Rico and the U.S. Virgin Islands: U.S. Geological Survey WaterResources Investigations Report 90-4088, 32 p.

Renken, R.A., Díaz, Pedro, Gómez-Gómez, Fernando, and Quiñones-Aponte, Vicente, 1990, Hydrologic excursion to Puerto Rico's Southern Plain: U.S. Geological Survey Open-File Report 90-365, 24 p., 1 pl.

Renken, R.A., Gómez-Gómez, Fernando, Quiñones-Aponte, Vicente, and Dacosta, Rafael, 1991, Structure and depositional patterns and their influence on the hydraulic conductivity of fan-deltas in southern Puerto Rico: in Gómez-Gómez, Fernando, Quiñones-Aponte, Vicente, and Johnson, A.I., eds., Aquifers of the Caribbean Islands, Proceedings of the International Symposium on Tropical Hydrology, San Juan, Puerto Rico, July 23-27, 1990, AWRA Monograph Series no. 15, p. 25-36.

Rickler, J.G., and others, 1970, Water records of Puerto Rico, 1964-67, Volume 1, north and northeast slopes: U.S. Geological Survey WaterData Report 71-238, 265 p.

Rickler, J.G., and others, 1970, Water records of Puerto Rico, 1964-67, Volume 2, south and west slopes: U.S. Geological Survey Water-Data Report, $308 \mathrm{p}$.

Robison, T.M., and others, 1972, Water records of the U.S. Virgin Islands, 1962-69: U.S. Geological Survey Water-Data Report, 163 p.

Román-Más, Angel, 1986, Role of blanket deposits on the hydrology and water chemistry of the limestone water-table aquifer within the north coast of Puerto Rico through interpretation of geochemical data: in Quiñones, Ferdinand, Sánchez, A.V., and Smith, H.H., eds., Proceedings of the Third Caribbean Islands Water-Resources Congress, U.S. Virgin Islands, July 22-25, 1986, Puerto Rico Water Resources Association, p. 33.

Santiago-Rivera, Luis, 1992, Low-flow characteristics at selected sites on streams in eastern Puerto Rico: U.S. Geological Survey WaterResources Investigations Report 92-4063, 46 p.

Santiago-Rivera, Luis, and Colón-Dieppa, Eloy, 1986, U.S. Virgin Islands surface-water resources - National Water Summary 1985: U.S. Geological Survey Water-Supply Paper 2300, p. 447-452.

Schuck-Kolben, R.E., and Kaufman, Lionel, 1991, Storm-surge flooding by Hurricane Hugo on the U.S. Virgin Islands, Puerto Rico, and South Carolina, September 1989 - National Water Summary 1988-89: U.S. Geological Survey Water-Supply Paper 2375, p. 59-64.

Torres-González, Arturo, and Díaz, J.R., 1984, Water resources of the Sabana Seca to Vega Baja area, Puerto Rico: U.S. Geological Survey Water-Resources Investigations Report 82-4115, 53 p.

Torres-González, Sigfredo, 1984, Water-resources investigations of Vieques Island, Puerto Rico: Proceedings of the First Caribbean Islands Water-Resources Congress, St. Thomas, U.S. Virgin Islands, July 26-27, 1984, p. 298-311.

U.S. Geological Survey, 1973, Water resources data for Puerto Rico, 1968, Part 1, Surface water records: U.S. Geological Survey Water-Data Report, 87 p.

U.S. Geological Survey, 1973, Water resources data for Puerto Rico, 1968, Part 2, Surface water records: U.S. Geological Survey Water-Data Report, 87 p.

U.S. Geological Survey, 1973, Water resources data for Puerto Rico, 1969, Part 1, Surface water records: U.S. Geological Survey Water-Data Report, 89 p.

U.S. Geological Survey, 1973, Water resources data for Puerto Rico, 1970, Part 1, Surface water records: U.S. Geological Survey Water-Data Report, 90 p.

U.S. Geological Survey, 1973, Water resources data for Puerto Rico, 1971, Part 1, Surface water records: U.S. Geological Survey Water-Data Report, 72 p.

U.S. Geological Survey, 1974, Water resources data for Puerto Rico, 1972, Part 1, Surface water records: U.S. Geological Survey Water-Data Report, 70 p. 


\section{Surface Water--Continued}

U.S. Geological Survey, 1975, Water resources data for Puerto Rico, 1973, Part 1, Surface water records: U.S. Geological Survey Water-Data Report, 69 p.

U.S. Geological Survey, 1976, Water resources data for Puerto Rico, 1974, Part 1, Surface water records: U.S. Geological Survey Water-Data Report, 66 p.

U.S. Geological Survey, 1978, Water resources data for Puerto Rico, Surface and quality-of-water records, Water Years 1975-76, Ground water records, Water Years 1973-76: U.S. Geological Survey Water-Data Report-PR-76-1, 366 p.

U.S. Geological Survey, 1979, Water-resources investigations in Puerto Rico and the U.S. Virgin Islands, 1978: U.S. Geological Survey Folder.

U.S. Geological Survey, 1980, Water resources data for Puerto Rico, Surface and quality-of-water records, Water Year 1977, Ground water records, Water Year 1977: U.S. Geological Survey Water-Data Report PR-77-1, 215 p.

U.S. Geological Survey, 1981, Water resources data for Puerto Rico, Water Year 1978: U.S. Geological Survey Water-Data Report PR-78-1, 255 p.

U.S. Geological Survey, 1982, Water resources data for Puerto Rico, Water Years 1979-80: U.S. Geological Survey Water-Data Report PR-79$80,408 \mathrm{p}$.

U.S. Geological Survey, 1983, Puerto Rico and the U.S. Virgin Islands water issues: National Water Summary 1983 - Hydrologic Events and Issues, U.S. Geological Survey Water-Supply Paper 2250, p. 200-202.

Vaughan, T.W., 1920, The ground-water resources of the West Indian Islands, St. John, St. Thomas, Culebra and Vieques, and of the eastern end of Puerto Rico: U.S. Geological Survey Open-File Report.

Veve, T.D., and Troester, J.W., 1990, Water-resources investigations in Puerto Rico and the U.S. Virgin Islands, 1986-1988: U.S. Geologic Survey Open-File Report 90-122, 39 p.

Ward, P.E., and Jordan, D.G., 1963, Water resources of the Virgin Islands, A preliminary appraisal, 1963: U.S. Geological Survey Open-File Report, 44 p.

Wilson, A., and Iseri, K.T., 1967, River discharge to the sea from the shores of the conterminous United States, Alaska, and Puerto Rico: U.S. Geological Survey Hydrology Investigations Atlas HA-282, 1 sheet.

Wilson, H.M., 1899, Water resources of Puerto Rico: U.S. Geological Survey Water-Supply Paper 32.

Woodward, T.H., and Heidel, S.G., 1964, Inventory of published and unpublished chemical analyses of surface waters in the continental United States and Puerto Rico, 1961: U.S. Geological Survey Water-Supply Paper 1786, 490 p.

Zack, A.L., and Class-Cacho, Angel, 1984, Restoration of freshwater in the Caño Tiburones area, Puerto Rico: U.S. Geological Survey WaterResources Investigations Report 83-4071, 33 p., 1 pl.

Zack, Allen, and Román-Más, Angel, 1988, Hydrology of the Caribbean Islands Wetlands: Proceedings of the Caribbean Islands Wetlands Workshop, Forestry \& Wildlife Management Institute, University of Massachusetts at Amherst, October 28-29, 1986, p. 65-73.

\section{Water Quality}

Arnow, Ted, and Bogart, D.B., 1959, Water problems of Puerto Rico and a program of water-resources investigations: Transactions of the Second Caribbean Geological Conference, January 4-9, 1959, Mayagüez, Puerto Rico, p. 120-129.

Bogart, D.B., Arnow, Ted, and Crooks, J.W., 1960, Water problems of Puerto Rico and a program of water-resources investigations: U.S. Geological Survey Water-Resources Bulletin 1, 40 p.

Bogart, D.B., Arnow, Ted, and Crooks, J.W., 1964, Water resources of Puerto Rico - A progress report: U.S. Geological Survey WaterResources Bulletin 4, 120 p.

Collar, P.D., 1991, Fluvial metal transport during a storm event, Río Grande de Loíza basin, Puerto Rico [Abstract]: The Geological Society of America, Abstracts with Programs, v. 23, no. 5, p. 203.

Collar, P.D., Troester, J.W., Deike, R.G., and Robinson, P.D., 1990, Iron and manganese in alluvial ground water, Yabucoa, Puerto Rico: Proceedings of the Interamerican Association of Sanitary and Environmental Engineers Annual Meeting, v. 3, p. $708-732$.

Colón-Dieppa, Eloy, and Mansue, L.J., 1976, Water resources of the proposed copper mining area, Puerto Rico, $1958-74$ (2 Parts): U.S. Geological Survey Open-File Report 76-1 and 76-2, 414 p. 


\section{Water Quality--Continued}

Colón-Dieppa, Eloy, Díaz, P.L., and García, René, 1987, Water resources data Puerto Rico and the U.S. Virgin Islands, Water Year 1985: U.S. Geological Survey Water-Data Report PR-85-1, 400 p.

Colón-Ramos, Héctor, and Colón-Dieppa, Eloy, 1981, Ground-water levels and chloride concentrations in alluvial aquifers on the south coast of Puerto Rico, February 1980: U.S. Geological Survey Open-File Report 81-626, 20 p.

Conde-Costas, Carlos, and Troester, J.W., 1988, The effects of bat guano on carbonate chemistry in Cueva El Convento, Guayanilla, Puerto Rico [Abstract]: National Speleological Society, Forty-Fifth Annual Convention Program, Hot Spring, South Dakota, June 27 to July 1 , 1988 , p. 34.

Cosner, O.J., 1972, Water in St. John, U.S. Virgin Islands: U.S. Geological Survey Open-File Report 72-78, 46 p.

Crooks, J.W., Grossman, I.G., and Bogart, D.B., 1968, Water resources of the Guayanilla-Yauco area, Puerto Rico: U.S. Geological Survey Water-Resources Bulletin 5, 55 p.

Curtis, R.E., Jr., Guzmán-Ríos, Senén, and Díaz, P.L., 1984, Water resources data Puerto Rico and the U.S. Virgin Islands, Water Year 1983: U.S. Geological Survey Water-Data Report PR-83-1, 302 p.

Curtis, R.E., Jr., Guzmán-Ríos, Senén, and Díaz, P.L., 1985, Water resources data Puerto Rico and the U.S. Virgin Islands, Water Year 1984: U.S. Geological Survey Water-Data Report PR-84-1, 374 p.

Curtis, R.E., Jr., McKinley P.W., and Colón-Ramos, H.M., 1983, Water resources data Puerto Rico, Water Years 1981-82: U.S. Geological Survey Water-Data Report PR-81-82-1, 414 p.

Curtis, R.E., Jr., Aquino, Zaida, Díaz, P.L., and García, René, 1988, Water resources data Puerto Rico and the U.S. Virgin Islands, Water Year 1986: U.S. Geological Survey Water-Data Report PR-86-1, 362 p.

Curtis, R.E., Jr., Aquino, Zaida, Díaz, P.L., and Vachier, Ricardo, 1989, Water resources data Puerto Rico and the U.S. Virgin Islands, Water Year 1987: U.S. Geological Survey Water-Data Report PR-87-1, 356 p.

Curtis, R.E., Jr., Aquino, Zaida, Díaz, P.L., and Vachier, Ricardo, 1989, Water resources data Puerto Rico and the U.S. Virgin Islands, Water Year 1988: U.S. Geological Survey Water-Data Report PR-88-1, 460 p.

Curtis, R.E., Jr., Aquino, Zaida, Díaz, P.L., and Vachier, Ricardo, 1990, Water resources data Puerto Rico and the U.S. Virgin Islands, Water Year 1989: U.S. Geological Survey Water-Data Report PR-89-1, 419 p.

Curtis, R.E., Jr., Aquino, Zaida, Díaz, P.L., and Vachier, Ricardo, 1991, Water resources data Puerto Rico and the U.S. Virgin Islands, Water Year 1990: U.S. Geological Survey Water-Data Report PR-90-1, 514 p.

Díaz, J.R., 1973, Chemical quality of water in Caño Tiburones, Puerto Rico: A reconnaissance study carried out in 1967: U.S. Geological Survey Open-File Report Map Series no. 2, 2 pls.

Díaz, J.R., 1974, Coastal salinity reconnaissance and monitoring system--south coast of Puerto Rico: U.S. Geological Survey Open-File Report $74-1,28 \mathrm{p}$.

Díaz, J.R., 1979, Seawater intrusion, south coast of Puerto Rico, 1966-77: U.S. Geological Survey Open-File Report 79-1334, 20 p.

Díaz, J.R., and Jordan, D.G., 1987, Water resources of the Río Grande de Añasco - lower Valley, Puerto Rico: U.S. Geological Survey WaterResources Investigations Report 85-4237, 48 p.

Durfor, C.N., and Becker, Edith, 1964, Chemical quality of public water supplies of the United States and Puerto Rico, 1962: U.S. Geological Survey Hydrologic Investigations Atlas HA-200, 1 sheet.

Durum, W.H., Hem, J.D., and Heidel, S.G., 1971, Reconnaissance of selected minor elements in surface waters of the United States, October 1970: U.S. Geological Survey Circular 643, 49 p.

Ellins, K.K., Román-Más, Angel, and Lee, R.N., 1986, Estimating ground water influx to a portion of the Río Grande de Manatí River basin in Puerto Rico through the measurement of ${ }^{222} \mathrm{Rn}$ : in Quiñones, Ferdinand, Sánchez, A.V., and Smith, H.H., eds., Proceedings of the Third Caribbean Islands Water-Resources Congress, U.S. Virgin Islands, July 22-25, 1986, Puerto Rico Water Resources Association, p. 27.

Ellis, S.R., and Gómez-Gómez, Fernando, 1975, Water-quality and hydraulic data, San Juan lagoon system, Puerto Rico: U.S. Geological Survey Open-File Report 75-2-PR, 142 p.

Ellis, S.R., and Gómez-Gómez, Fernando, 1976, Hydrologic characteristics of lagoons at San Juan, Puerto Rico, during a January 1974 tidal cycle: U.S. Geological Survey Water-Resources Investigations Report 75-38, 45 p.

García, René, and Canoy, Michael, 1984, Reconnaissance of ground-water quality in the Virgin Islands, July 1984: U.S. Geological Survey Open-File Data Report 84-807, 1 sheet.

Giusti, E.V., 1968, Water resources of the Juana Díaz area, Puerto Rico - A preliminary appraisal, 1966: U.S. Geological Survey WaterResources Bulletin 8, 43 p. 


\section{Water Quality--Continued}

Giusti, E.V., 1971, Water resources of the Coamo area, Puerto Rico: U.S. Geological Survey Water-Resources Bulletin 9, 31 p.

Giusti, E.V., and Bennett, G.D., 1976, Water resources of the north coast limestone area, Puerto Rico: U.S. Geological Survey Water-Resources Investigations Report 75-42, $42 \mathrm{p}$

Gómez-Gómez, Fernando, 1984, Water resources of the lower Río Grande de Manatí Valley: U.S. Geological Survey Water-Resources Investigations Report 83-4199, 42 p.

Gómez-Gómez, Fernando, 1986, Caribbean Islands Regional Aquifer-System Study - Phase 1, Regional Aquifer-System Study projects started in 1984: in Ren Jen Sun, ed., Summary of Projects 1978-84: U.S. Geological Survey Circular 1002, p. $234-241$.

Gómez-Gómez, Fernando, 1987, Planning report for the Caribbean Islands Regional Aquifer-System Analysis project: U.S. Geological Survey Water-Resources Investigations Report 86-4074, 50 p., 3 pls.

Gómez-Gómez, Fernando, 1990, Hydrochemistry of the South Coastal Plain Aquifer System of Puerto Rico and its relation to surface-water recharge: in Gomez-Gómez, Fernando, Quiñones-Aponte, Vicente, and Johnson, A.I., eds., Aquifers of the Caribbean Islands, Proceedings of the International Symposium on Tropical Hydrology, San Juan, Puerto Rico, July 23-27, 1990, AWRA Monograph Series no. 15, p. 57-75.

Gómez-Gómez, Fernando, and Guzmán-Ríos, Senén, 1982, Reconnaissance of ground-water quality throughout Puerto Rico, SeptemberOctober 1981: U.S. Geological Survey Open-File Report 82-332, 1 sheet.

Graves, R.P., 1989, Water resources of the Humacao-Naguabo area, eastern Puerto Rico: U.S. Geological Survey Water-Resources Investigations Report 87-4088, 69 p.

Graves, R.P., 1991, Ground-water resources in Lajas Valley, Puerto Rico: U.S. Geological Survey Water-Resources Investigations Report $89-4182,55 \mathrm{p}$.

Grossman, I.G., 1962, Chemical quality of ground water in St. Thomas, Virgin Islands: in Short Papers in Geology, Hydrology, and Topography, Articles 1-59, U.S. Geological Survey Professional Paper 450-B, Article 55, p. 131-133.

Grossman, I.G., Bogart, D.B., Crooks, J.W., and Díaz, J.R., 1972, Water resources of the Tallaboa Valley, Puerto Rico: U.S. Geological Survey Water-Resources Bulletin 7, $115 \mathrm{p}$.

Guzmán-Ríos, Senén, 1983, Reconnaissance of the principal springs of Puerto Rico, 1982-83: U.S. Geological Survey Open-File Data Report 83-683, 1 sheet.

Guzmán-Ríos, Senén, 1988, Hydrology and water quality of the principal springs in Puerto Rico: U.S. Geological Survey Water-Resources Investigations Report 85-4269, 30 p.

Guzmán-Ríos, Senén, and Quiñones-Márquez, Ferdinand, 1984, Ground-water quality at selected sites throughout Puerto Rico, September 1982 - July 1983: U.S. Geological Survey Open-File Data Report 84-058, 1 sheet.

Guzmán-Ríos, Senén, and Quiñones-Márquez, Ferdinand, 1985, Reconnaissance of trace organic compounds in ground water throughout Puerto Rico, October 1983: U.S. Geological Survey Open-File Data Report 84-810, 1 sheet.

Jordan, D.G., 1970, Water and copper-mine tailings in karst terrane of Río Tanamá basin, Puerto Rico: U.S. Geological Survey Open-File Report $71-163,24 \mathrm{p}$.

Jordan, D.G., 1975, A survey of the water resources of St. Croix, Virgin Islands: U.S. Geological Survey Open-File Report 73-137, 51 p.

Jordan, D.G., and Cosner, O.J., 1973, A survey of the water resources of St. Thomas, Virgin Islands: U.S. Geological Survey Open-File Report $72-201,55 \mathrm{p}$.

Jordan, D.G., and Gilbert, B.K., 1976, Water supply and waste disposal, Culebra, Puerto Rico: U.S. Geological Survey Water-Resources Investigations $76-3,31 \mathrm{p}$.

Kipple, F.P., and others, 1968, Water records of Puerto Rico, 1958-63: U.S. Geological Survey Water-Data Report, 353 p.

Lohr, E.W., 1957, Chemical character of public water supplies of the larger cities in Alaska, Hawaii, and Puerto Rico, 1954: U.S. Geological Survey Water-Supply Paper 1460-A, 39 p., 1 pl.

McClymonds, N.E., 1967, Water resources of the Guánica area, Puerto Rico - A preliminary appraisal, 1963: U.S. Geological Survey WaterResources Bulletin 6, 43 p.

McClymonds, N.E., 1972, Water resources of the Ponce area, Puerto Rico: U.S. Geological Survey Water-Resources Bulletin 14, 26 p.

McClymonds, N.E., and Díaz, J.R., 1972, Water resources of the Jobos area, Puerto Rico - A preliminary appraisal, 1962: U.S. Geological Survey Water-Resources Bulletin 13, 32 p.

McClymonds, N.E., and Ward, P.E., 1966, Hydrologic characteristics of the alluvial fan near Salinas, Puerto Rico: in Geological Survey Research 1966, Chap. C, U.S. Geological Survey Professional Paper 550-C, p. 231-234.

McCoy, J.H., 1978, Summary of the water resources of Puerto Rico: U.S. Geological Survey Open-File Report 78-971, 24 p.

McGuinness, C.L., 1953, Summary of the water resources of the Virgin Islands: U.S. Geological Survey Open-File Report, 8 p. 
Water Quality--Continued

Puig, J.C., and Rodriguez, J.M., 1992, Ground-water resources of the Caguas-Juncos Valley, Puerto Rico: U.S. Geological Survey WaterResources Investigations Report 91-4079, 48 p.

Quiñones, Ferdinand, and Alicea, José, 1981, Water resources investigations in Puerto Rico and the U.S. Virgin Islands - Programs and activities of the U.S. Geological Survey, Water Resources Division, Caribbean District: U.S. Geological Survey Open-File Report, 69 p.

Quiñones, Ferdinand, and Alicea, José, 1983, Water resources investigations in Puerto Rico and the U.S. Virgin Islands - Programs and activities of the U.S. Geological Survey, Water Resources Division, Caribbean District: U.S. Geological Survey Open-File Report, 28 p.

Quiñones, Ferdinand, and Alicea, José, 1984, Water resources investigations in Puerto Rico and the U.S. Virgin Islands - Programs and activities of the U.S. Geological Survey, Water Resources Division, Caribbean District: U.S. Geological Survey Open-File Report, 41 p.

Quiñones-Aponte, Vicente, 1986, Water resources of the lower Río Grande de Arecibo alluvial valley, Puerto Rico: U.S. Geological Survey Water-Resources Investigations Report 85-4160, 38 p., 1 pl.

Quiñones-Aponte, Vicente, 1989, Hydrogeologic characteristics of the lower Río Grande de Arecibo alluvial valley: Proceedings of the 13th Natural Resources Symposium, San Juan, Puerto Rico, February 26, 1987, Puerto Rico Department of Natural Resources, p. $41-59$.

Quiñones-Márquez, Ferdinand, 1973, Chemical-quality and flow-duration curves for selected streams in Puerto Rico: U.S. Geological Survey Open-File Report PR-7.

Quiñones-Márquez, Ferdinand, 1975, Chemical, biochemical, and bacteriological determinations at selected stream sites in Puerto Rico: U.S. Geological Survey Open-File Report 75-1, 118 p.

Quiñones-Márquez, Ferdinand, 1975, Chemical composition of rainfall at selected sites in Puerto Rico: U.S. Geological Survey Open-File Report 75-364, $17 \mathrm{p}$.

Quiñones-Márquez, Ferdinand, 1976, Chemical, physical, biochemical, and bacteriological determinations in Lago Loíza, Puerto Rico, and in its main tributaries, September 1973 - December 1974: U.S. Geological Survey Open-File Report 76-7, 74 p.

Quiñones-Márquez, Ferdinand, 1976, Chemical, physical, biochemical, and bacteriological determinations in Laguna Tortuguero, Puerto Rico, July 1974 - June 1975: U.S. Geological Survey Open-File Report 76-5, 39 p.

Quiñones-Márquez, Ferdinand, 1978, Selected chemical properties of rainfall in the Río Piedras basin, Puerto Rico: U.S. Geological Survey Open-File Report 78-159, 14 p.

Quiñones-Márquez, Ferdinand, 1980, Limnology of Lago Loíza, Puerto Rico: U.S. Geological Survey Water-Resources Investigations Report 79-97, $113 \mathrm{p}$.

Quiñones-Márquez, Ferdinand, and Fusté, L.A., 1978, Limnology of Laguna Tortuguero, Puerto Rico: U.S. Geological Survey WaterResources Investigations Report 77-122,86 p.

Quiñones-Márquez, Ferdinand, and Peña-Cruz, Gilberto, 1985, Water resources investigations in Puerto Rico and the U.S. Virgin Islands Programs and activities of the U.S. Geological Survey, Water Resources Division, Caribbean District 1984-1985: U.S. Geological Survey Open-File Report 85-556, 43 p.

Quiñones-Márquez, Ferdinand, Guzmán-Ríos, Senén, 1986, Determinación de caudal y técnicas de muestreo en agua superficial: U.S. Geological Survey Water-Resources Investigations Report 85-89, 68 p.

Quiñones-Márquez, Ferdinand, López, M.A., and Latkovich, V.J., 1976, Water records of the Río Piedras basin, Puerto Rico, 1971-74: U.S. Geological Survey Open-File Report 76-3, 111 p.

Quiñones-Márquez, Ferdinand, Vázquez, Pedro, and Peña, Rafael, 1977, Chemical, physical, biochemical, and bacteriological characteristics at selected stream sites in Puerto Rico, 1975-76: U.S. Geological Survey Open-File Report 77-237, 176 p.

Quiñones-Márquez, Ferdinand, Vázquez, Pedro, and Peña-Cortés, Rafael, 1978, Chemical, physical, biochemical, and bacteriological characteristics at selected stream sites in Puerto Rico 1976-77: U.S. Geological Survey Open-File Report 78-445, 145 p.

Quiñones-Márquez, Ferdinand, Vázquez, Pedro, Class, Angel, and Peña, Rafael, 1976, Chemical, physical, biochemical, and bacteriological characteristics at selected stream sites in Puerto Rico, 1974-75: U.S. Geological Survey Open-File Report 76-1, 163 p.

Rickler, J.G., and others, 1970, Water records of Puerto Rico, 1964-67, Volume 1, north and northeast slopes: U.S. Geological Survey WaterData Report 71-238, 265 p.

Rickler, J.G., and others, 1970, Water records of Puerto Rico, 1964-67, Volume 2, south and west slopes: U.S. Geological Survey Water-Data Report, 308 p.

Robison, T.M., and others, 1972, Water records of the U.S. Virgin Islands, 1962-69: U.S. Geological Survey Water-Data Report, 163 p. 


\section{Water Quality--Continued}

Román-Más, Angel, 1986, Role of blanket deposits on the hydrology and water chemistry of the limestone water-table aquifer within the north coast of Puerto Rico through interpretation of geochemical data: in Quiñones, Ferdinand, Sánchez, A.V., and Smith, H.H., eds., Proceedings of the Third Caribbean Islands Water-Resources Congress, U.S. Virgin Islands, July 22-25, 1986, Puerto Rico Water Resources Association, p. 33.

Román-Más, Angel, and Lee, R.W., 1985, Water quality and chemical evolution of ground water within the north coast limestone aquifers of Puerto Rico: Proceedings of the Tropical Hydrology and Second Caribbean Islands Water-Resources Congress, May 5-8, 1985, American Water Resources Association, Technical Publication Series TPS-85-1, p. 57-63.

Román-Más, Angel, and Lee, R.W., 1987, Geochemical evolution of waters within the north coast limestone aquifers of Puerto Rico: A conceptualization based on a flow path in the Barceloneta area: U.S. Geological Survey Water-Resources Investigations Report 86-4080, 28 p.

Román-Más, Angel, and Ramos-Ginés, Orlando, 1988, Compilation of water quality data for the north coast limestone aquifers, Puerto Rico, 1951 to 1987: U.S. Geological Survey Open-File Data Report 87-533, 133 p.

Torres-González, Arturo, and Díaz, J.R., 1984, Water resources of the Sabana Seca to Vega Baja area, Puerto Rico: U.S. Geological Survey Water-Resources Investigations Report 82-4115, 53 p.

Torres-González, Sigfredo, 1984, Water-resources investigations of Vieques Island, Puerto Rico: Proceedings of the First Caribbean Islands Water-Resources Congress, St. Thomas, U.S. Virgin Islands, July 26-27, 1984, p. 298-311.

Troester, J.W., and White, W.B., 1988, The carbonate chemistry of the Río Camuy drainage basin, Puerto Rico: A Humid Tropical Karst [Abstract]: National Speleological Society, Annual Convention Program, p. 34.

Troester, J.W., and White, W.B., 1989, Carbonate chemistry and hydrogeology of Río Camuy drainage basin, Puerto Rico [Abstract]: Humid Tropical Karst 28th International Geologic Congress, Washington D.C., July 9-19, 1989, v. 3, p. 255.

Troester, J.W., Collar, P.D., Robinson, P.D., and Deike, R.G., 1990, Geochemical processes controlling manganese and iron concentrations in the ground water of the Valle de Yabucoa alluvial aquifer, Puerto Rico [Abstract]: EOS, Transactions, American Geophysical Union, April 24, 1990 , v. 71 , no. 17 , p. 506.

U.S. Geological Survey, 1973, Water resources data for Puerto Rico, 1968, Part 1, Surface water records: U.S. Geological Survey Water-Data Report, 87 p.

U.S. Geological Survey, 1973, Water resources data for Puerto Rico, 1968, Part 2, Surface water records: U.S. Geological Survey Water-Data Report, 87 p.

U.S. Geological Survey, 1973, Water resources data for Puerto Rico, 1969, Part 1, Surface water records: U.S. Geological Survey Water-Data Report, 89 p.

U.S. Geological Survey, 1973, Water resources data for Puerto Rico, 1970, Part 1, Surface water records: U.S. Geological Survey Water-Data Report, 90 p.

U.S. Geological Survey, 1973, Water resources data for Puerto Rico, 1971, Part 1, Surface water records: U.S. Geological Survey Water-Data Report, 72 p.

U.S. Geological Survey, 1974, Water resources data for Puerto Rico, 1972, Part 1, Surface water records: U.S. Geological Survey Water-Data Report, 70 p.

U.S. Geological Survey, 1974, Water resources data for Puerto Rico, 1968-72, Part 2A, Water quality records: U.S. Geological Survey WaterData Report, 410 p.

U.S. Geological Survey, 1975, Water resources data for Puerto Rico, 1973, Part 2, Water quality records: U.S. Geological Survey Water-Data Report, 133 p.

U.S. Geological Survey, 1975, Water resources data for Puerto Rico, 1968-72, Part 2B, Water quality records (sediment): U.S. Geological Survey Water-Data Report, 182 p.

U.S. Geological Survey, 1976, Water resources data for Puerto Rico, 1974, Part 2, Water quality records: U.S. Geological Survey Water-Data Report, $158 \mathrm{p}$.

U.S. Geological Survey, 1978, Water resources data for Puerto Rico, Surface and quality-of-water records, Water Years 1975-76, Ground water records, Water Years 1973-76: U.S. Geological Survey Water-Data Report-PR-76-1, 366 p.

U.S. Geological Survey, 1979, Water-resources investigations in Puerto Rico and the U.S. Virgin Islands, 1978: U.S. Geological Survey Folder. 


\section{Water Quality--Continued}

U.S. Geological Survey, 1980, Water resources data for Puerto Rico, Surface and quality-of-water records, Water Year 1977, Ground water records, Water Year 1977: U.S. Geological Survey Water-Data Report PR-77-1, 215 p.

U.S. Geological Survey, 1981, Water resources data for Puerto Rico, Water Year 1978: U.S. Geological Survey Water-Data Report PR-78-1, 255 p.

U.S. Geological Survey, 1982, Water resources data for Puerto Rico, Water Years 1979-80: U.S. Geological Survey Water-Data Report PR-79-80, $408 \mathrm{p}$.

U.S. Geological Survey, 1983, Puerto Rico and the U.S. Virgin Islands water issues: National Water Summary 1983 - Hydrologic Events and Issues, U.S. Geological Survey Water-Supply Paper 2250, p. 200-202.

Vaughan, T.W., 1920, The ground-water resources of the West Indian Islands, St. John, St. Thomas, Culebra and Vieques, and of the eastern end of Puerto Rico: U.S. Geological Survey Open-File Report.

Veve, T.D., and Troester, J.W., 1990, Water-resources investigations in Puerto Rico and the U.S. Virgin Islands, 1986-1988: U.S. Geologic Survey Open-File Report 90-122, 39 p.

Ward, P.E., and Jordan, D.G., 1963, Water resources of the Virgin Islands, A preliminary appraisal, 1963: U.S. Geological Survey Open-File Report, 44 p.

Whitesides, D.V., Quiñones-Aponte, Vicente, and Zack, A.L., 1985, Estimating the capacity of a salty limestone aquifer in Puerto Rico to receive, store, and release injected freshwater using chloride mass balance: Proceedings of the Second Caribbean Islands Water-Resources Congress and Tropical Hydrology, May 5-8, 1985, American Water Resources Association, Technical Publication Series TPS-85-1, p. 50-55.

Wilson, H.M., 1899, Water resources of Puerto Rico: U.S. Geological Survey Water-Supply Paper 32.

Woodward, T.H., and Heidel, S.G., 1964, Inventory of published and unpublished chemical analyses of surface waters in the continental United States and Puerto Rico, 1961: U.S. Geological Survey Water-Supply Paper 1786, 490 p.

Zack, A.L., Rodríguez-Alonso, Teresita, and Román-Más, Angel, 1987, Puerto Rico ground-water quality - National Water Summary: U.S. Geological Survey Water-Supply Paper 2325, p. 437-442.

Zack, A.L., Rodríguez-Alonso, Teresita, and Román-Más, Angel, 1987, U.S. Virgin Islands ground-water quality - National Water Summary: U.S. Geological Survey Water-Supply Paper 2325, p. 489-492.

\section{Water Use}

Gómez-Gómez, Fernando, Dacosta, Rafael, and Orona, Miguel, 1983, Estimated water use in Puerto Rico, 1980 -- U.S. Geological Survey water-use information program: U.S. Geological Survey Water Resources Division Miscellaneous Map Series, 1 sheet.

Román-Más, Angel, 1986, Role of blanket deposits on the hydrology and water chemistry of the limestone water-table aquifer within the north coast of Puerto Rico through interpretation of geochemical data: in Quiñones, Ferdinand, Sánchez, A.V., and Smith, H.H., eds., Proceedings of the Third Caribbean Islands Water-Resources Congress, U.S. Virgin Islands, July 22-25, 1986, Puerto Rico Water Resources Association, p. 33.

Román-Más, Angel, 1986, Role of climatic data in determining the water required, used, and supplied for irrigation in the rice-growing areas along the north coast of Puerto Rico [Abstract]: Conference on Climate and Water Management - A Critical Era, American Meteorological Society, August 4-7, 1986, p. 1-9.

Román-Más, Angel, 1988, Water required, water used, and potential water sources for rice irrigation, north coast of Puerto Rico: U.S. Geological Survey Water-Resources Investigations Report 86-4334, 35 p.

Torres-Sierra, Heriberto, 1986, Estimated water use in St. Croix, U.S. Virgin Islands, 1983-1985: in Quiñones, Ferdinand, Sánchez, A.V., and Smith, H.H., eds., Proceedings of the Third Caribbean Islands Water-Resources Congress, U.S. Virgin Islands, July 22-25, 1986, Puerto Rico Water Resources Association, p. 7-11.

Torres-Sierra, Heriberto, 1987, Estimated water use in St. Croix, U.S. Virgin Islands, October 1983 - September 1985: U.S. Geological Survey Open-File Data Report 86-537, 1 sheet.

Torres-Sierra, Heriberto, and Avilés, Ada, 1986, Estimated water use in Puerto Rico, 1980-82: U.S. Geological Survey Open-File Data Report 85-557, $77 \mathrm{p}$.

Torres-Sierra, Heriberto, and Dacosta, Rafael, 1984, Estimated water use in St. Thomas, U.S. Virgin Islands, July 1983 - June 1984: U.S. Geological Survey Open-File Data Report 84-721, 1 sheet. 


\section{PUBLICATIONS SERIES OR TYPES OF PUBLICATIONS}

Most of the publications listed were published by the U.S. Geological Survey, Caribbean District. Publications that are listed numerically in a series are also presented numerically in this section. For an unnumbered series, publications are listed alphabetically by senior author. The definition for each series or type of publication in the U.S. Geological Survey used in this report is from "Publications of the U.S. Geological Survey" (U.S. Department of the Interior, 1990). 


\section{PUBLICATIONS SERIES OR TYPES OF PUBLICATIONS}

\section{Circulars}

Circulars present technical or nontechnical information of popular interest. They are published to disseminate administrative information or important scientific information of an transitory nature.

451

Barnes, H.H., Jr., and Bogart, D.B., 1961, Floods of September 6, 1960, in eastern Puerto Rico: U.S. Geological Survey Circular $451,13 \mathrm{p}$.

643

Durum, W.H., Hem, J.D., and Heidel, S.G., 1971, Reconnaissance of selected minor elements in surface waters of the United States, October 1970: U.S. Geological Survey Circular 643, 49 p.

1002

Gómez-Gómez, Fernando, 1986, Caribbean Islands Regional Aquifer-System Study - Phase 1, Regional Aquifer-System Study projects started in 1984: in Ren Jen Sun, ed., Summary of Projects 1978-84: U.S. Geological Survey Circular 1002, p. 234-241.

1006

Quiñones-Márquez, Ferdinand, 1987, Management and development of surface and ground water: in Krushesky, R.D., ed., Proceedings of the Development of Mineral, Energy, and Water Resources and Mitigation of Geologic Hazards in Central America, U.S. Geological Survey Circular 1006, p. 140-149.

\section{Hydrologic Investigations Atlases}

Hydrologic Investigations Atlases present multicolored or black and white maps on topographic or planimetric bases presenting a wide range of hydrologic and hydrogeologic data of regional and national interest, such as streamflow, ground water, water quality, and extent of flooding.

HA-77 López, M.A., 1962, Floods at Bayamón and Cataño, Puerto Rico: U.S. Geological Survey Hydrologic Investigations Atlas HA-77, 1 sheet.

HA-128 López, M.A., 1964, Floods at Toa Alta, Toa Baja, and Dorado, Puerto Rico: U.S. Geological Survey Hydrologic Investigations Atlas HA-128, 1 sheet.

HA-197 Briggs, R.P., and Akers, J.P., 1965, Hydrogeologic map of Puerto Rico and adjacent islands: U.S. Geological Survey Hydrologic Investigations Atlas HA-197, 1 sheet.

HA-200 Durfor, C.N., and Becker, Edith, 1964, Chemical quality of public water supplies of the United States and Puerto Rico, 1962: U.S. Geological Survey Hydrologic Investigations Atlas HA-200, 1 sheet.

HA-261 Hickenlooper, I.J., and López, M.A., 1967, Floods in the Ponce area, Puerto Rico: U.S. Geological Survey Hydrologic Investigations Atlas HA-261, 1 sheet.

HA-262 Hickenlooper, I.J., 1967, Floods at Barceloneta and Manatí, Puerto Rico: U.S. Geological Survey Hydrologic Investigations Atlas HA-262, 1 sheet.

HA-265 López, M.A., 1967, Floods at Humacao, Puerto Rico: U.S. Geological Survey Hydrologic Investigations Atlas HA-265, 1 sheet.

HA-271 Hickenlooper, I.J., 1968, Floods at Arecibo, Puerto Rico: U.S. Geological Survey Hydrologic Investigations Atlas HA-271, 1 sheet.

HA-282 Wilson, A., and Iseri, K.T., 1967, River discharge to the sea from the shores of the conterminous United States, Alaska, and Puerto Rico: U.S. Geological Survey Hydrology Investigations Atlas HA-282, 1 sheet.

HA-288 Hickenlooper, I.J., 1968, Floods in the Mayagüez area of Puerto Rico: U.S. Geological Survey Hydrologic Investigations Atlas HA-288, 1 sheet.

HA-289 Hickenlooper, I.J., 1968, Floods in the area of Vega Alta and Vega Baja, Puerto Rico: U.S. Geological Survey Hydrologic Investigations Atlas HA-289, 1 sheet.

HA-375 Fields, F.K., 1971, Floods in the Añasco area, Puerto Rico: U.S. Geological Survey Hydrologic Investigations Atlas HA-375, 1 sheet.

HA-382 Fields, F.K., 1971, Floods in the Yabucoa area, Puerto Rico: U.S. Geological Survey Hydrologic Investigations Atlas HA-382, 1 sheet.

HA-414 Fields, F.K., 1971, Floods in the Guayanilla-Yauco area, Puerto Rico: U.S. Geological Survey Hydrologic Investigations Atlas HA-414, 1 sheet. 


\section{Hydrologic Investigations Atlases--Continued}

HA-430 Fields, F.K., and Jordan, D.G., 1972, Storm-wave swash along the north coast of Puerto Rico: U.S. Geological Survey Hydrologic Investigations Atlas HA-430, 2 sheets.

HA-438 Fields, F.K., 1972, Floods at Caguas, Gurabo, Juncos, and San Lorenzo, Puerto Rico: U.S. Geological Survey Hydrologic Investigations Atlas HA-438, 1 sheet.

HA-445 Haire, W.J., 1971, Floods in the Patillas-Maunabo area, Puerto Rico: U.S. Geological Survey Hydrologic Investigations Atlas HA-445, 1 sheet.

HA-446 Haire, W.J., 1971, Floods in the Guayama area, Puerto Rico: U.S. Geological Survey Hydrologic Investigations Atlas HA-446, 1 sheet.

HA-447 Haire, W.J., 1971, Floods in Salinas area, Puerto Rico: U.S. Geological Survey Hydrologic Investigations Atlas HA-447, 1 sheet.

HA-448 Haire, W.J., 1971, Floods in the Santa Isabel area, Puerto Rico: U.S. Geological Survey Hydrologic Investigations Atlas HA-448, 1 sheet.

HA-456 Haire, W.J., 1972, Floods in the Río Guanajibo Valley, southwestern Puerto Rico: U.S. Geological Survey Hydrologic Investigations Atlas HA-456, 1 sheet.

HA-457 Johnson, K.G., 1972, Floods in the Aguadilla-Aguada area, northwestern Puerto Rico: U.S. Geological Survey Hydrologic Investigations Atlas HA-457, 1 sheet.

HA-532 Johnson, K.G., 1974, Floods in eastern Lajas Valley and the lower Río Loco basin, southwestern Puerto Rico: U.S. Geological Survey Hydrologic Investigations Atlas HA-532, 1 sheet.

HA-533 Haire, W.J., 1975, Floods in the Carolina-Río Grande area, northeastern Puerto Rico: U.S. Geological Survey Hydrologic Investigations Atlas HA-533, 1 sheet.

HA-545 Haire, W.J., 1975, Floods in the Fajardo-Luquillo area, northeastern Puerto Rico: U.S. Geological Survey Hydrologic Investigations Atlas HA-545, 1 sheet.

HA-584 Haire, W.J., 1978, Floods in the Naguabo area, eastern Puerto Rico: U.S. Geological Survey Hydrologic Investigations Atlas HA584,1 sheet.

\section{Numbered Open-File Reports}

Open-File Reports include unedited manuscript, maps, and other material, made available for public consultation and use. They are a nonpermanent form of publication that may be cited in other publications as sources of information. They are not considered to be a part of the formal literature.

71-5

71-86

71-163

72-78

72-201

73-137

73-242

74-1

74-4

75-1
Anders, R.B., 1971, Electric analog model study of water in the Yabucoa Valley, Puerto Rico (Phase-1, Collecting preliminary data and assembling available data): U.S. Geological Survey Open-File Report 71-5, 47 p.

Díaz, J.R., 1971, Electric analog model study of water in the Guayama area, Puerto Rico (Phase-1, Assembling data for the analog model): U.S. Geological Survey Open-File Report 71-86, 68 p.

Jordan, D.G., 1970, Water and copper-mine tailings in karst terrane of Río Tanamá basin, Puerto Rico: U.S. Geological Survey Open-File Report 71-163, 24 p.

Cosner, O.J., 1972, Water in St. John, U.S. Virgin Islands: U.S. Geological Survey Open-File Report 72-78, 46 p.

Jordan, D.G., and Cosner, O.J., 1973, A survey of the water resources of St. Thomas, Virgin Islands: U.S. Geological Survey Open-File Report 72-201, 55 p.

Jordan, D.G., 1975, A survey of the water resources of St. Croix, Virgin Islands: U.S. Geological Survey Open-File Report 73$137,51 \mathrm{p}$.

Robison, T.M., and Anders, R.B., 1973, Electric analog model study of the alluvial aquifer in the Yabucoa Valley, Puerto Rico (Phase 2--The planning, construction, and use of the model): U.S. Geological Survey Open-File Report 73-242, 47 p.

Díaz, J.R., 1974, Coastal salinity reconnaissance and monitoring system--south coast of Puerto Rico: U.S. Geological Survey Open-File Report 74-1, 28 p.

Bennett, G.D., 1976, Electrical analog simulation of the aquifers along the south coast of Puerto Rico: U.S. Geological Survey Open-File Report 74-4, 101 p.

Quiñones-Márquez, Ferdinand, 1975, Chemical, biochemical, and bacteriological determinations at selected stream sites in Puerto Rico: U.S. Geological Survey Open-File Report 75-1, 118 p. 


\section{Numbered Open-File Reports--Continued}

75-2

75-94

75-364

76-1

76-1

76-3

76-5

76-7

76-625

76-705

77-136

77-237

77-674

77-696

78-159

78-445

78-583

78-882

78-971

79-1272

79-1334

79-1338

80-1282

Ellis, S.R., and Gómez-Gómez, Fernando, 1975, Water-quality and hydraulic data, San Juan lagoon system, Puerto Rico: U.S. Geological Survey Open-File Report 75-2-PR, 142 p.

Attanasi, E.D., Close, E.R., and López, M.A., 1975, Techniques for water demand analysis and forecasting, Puerto Rico, A case study: U.S. Geological Survey Open-File Report 75-94, 76 p.

Quiñones-Márquez, Ferdinand, 1975, Chemical composition of rainfall at selected sites in Puerto Rico: U.S. Geological Survey Open-File Report 75-364, 17 p.

Quiñones-Márquez, Ferdinand, Vázquez, Pedro, Class, Angel, and Peña, Rafael, 1976, Chemical, physical, biochemical, and bacteriological characteristics at selected stream sites in Puerto Rico, 1974-75: U.S. Geological Survey Open-File Report 76-1, $163 \mathrm{p}$.

Colón-Dieppa, Eloy, and Mansue, L.J., 1976, Water resources of the proposed copper mining area, Puerto Rico, $1958-74$ (2 Parts): U.S. Geological Survey Open-File Report 76-1 and 76-2, 414 p.

Quiñones-Márquez, Ferdinand, López, M.A., and Latkovich, V.J., 1976, Water records of the Río Piedras basin, Puerto Rico, 1971-74: U.S. Geological Survey Open-File Report 76-3, 111 p.

Quiñones-Márquez, Ferdinand, 1976, Chemical, physical, biochemical, and bacteriological determinations in Laguna Tortuguero, Puerto Rico, July 1974 - June 1975: U.S. Geological Survey Open-File Report 76-5, 39 p.

Quiñones-Márquez, Ferdinand, 1976, Chemical, physical, biochemical, and bacteriological determinations in Lago Loíza, Puerto Rico, and in its main tributaries, September 1973 - December 1974: U.S. Geological Survey Open-File Report 76-7, 74 p.

Díaz, J.R., 1977, Ground-water levels on the south coast of Puerto Rico, February 1974 to February 1975: U.S. Geological Survey Open-File Report 76-625, 30 p.

Heisel, J.E., and González, J.R., 1976, Ground-water levels on the south coast of Puerto Rico, February 1976: U.S. Geological Survey Open-File Report 76-705, 13 p.

Haire, W.J., and Johnson, K.G., 1978, Floods of November 11-13, 1974, in St. Croix, U.S. Virgin Islands: U.S. Geological Survey Water-Resources Investigations Report 77-136, 11 sheets.

Quiñones-Márquez, Ferdinand, Vázquez, Pedro, and Peña, Rafael, 1977, Chemical, physical, biochemical, and bacteriological characteristics at selected stream sites in Puerto Rico, 1975-76: U.S. Geological Survey Open-File Report 77-237, 176 p.

Cobb, E.D., 1977, Activities of the Water Resources Division of the U.S. Geological Survey in the Caribbean area in 1976: U.S. Geological Survey Open-File Report 77-674, 32 p.

Díaz, J.R., 1977, Ground-water levels in alluvium on the south coast of Puerto Rico, February 1977: U.S. Geological Survey Open-File Report 77-696, 6 p.

Quiñones-Márquez, Ferdinand, 1978, Selected chemical properties of rainfall in the Río Piedras basin, Puerto Rico: U.S. Geological Survey Open-File Report 78-159, 14 p.

Quiñones-Márquez, Ferdinand, Vázquez, Pedro, and Peña-Cortés, Rafael, 1978, Chemical, physical, biochemical, and bacteriological characteristics at selected stream sites in Puerto Rico 1976-77: U.S. Geological Survey Open-File Report $78-445,145 \mathrm{p}$.

Cobb, E.D., 1978, Estimates of 7-day, 10-year minimum flows at selected stream sites in Puerto Rico: U.S. Geological Survey Open-File Report 78-583, 19 p.

Colón-Dieppa, Eloy, and González, Ralph, 1978, Cross section data for selected Puerto Rico streams: U.S. Geological Survey Open-File Report 78-882, 153 p.

McCoy, J.H., 1978, Summary of the water resources of Puerto Rico: U.S. Geological Survey Open-File Report 78-971, 24 p.

Díaz, J.R., 1979, Ground-water levels in alluvium on the south coast of Puerto Rico, February 1978: U.S. Geological Survey Open-File Report 79-1272, 18 p.

Díaz, J.R., 1979, Seawater intrusion, south coast of Puerto Rico, 1966-77: U.S. Geological Survey Open-File Report 79-1334, $20 \mathrm{p}$.

Gómez-Gómez, Fernando, 1979, Reconnaissance of six solid-waste disposal sites in Puerto Rico and effects on water quality: U.S. Geological Survey Open-File Report 79-1338, 73 p.

Johnson, K.G., 1982, Flood of September 16, 1975, in the Guayanilla Valley, Puerto Rico: U.S. Geological Survey WaterResources Investigations Open-File Report 80-1282, 1 sheet. 


\section{Numbered Open-File Reports--Continued}

80-1283 Johnson, K.G., 1981, Flood of September 16, 1975, in Tallaboa Valley, Puerto Rico: U.S. Geological Survey Water-Resources Investigations Open-File Report 80-1283, 5 sheets.

81-331 Johnson, K.G., 1982, Flood of September 16, 1975, in the Yauco Valley, Puerto Rico: U.S. Geological Survey Open-File Report $81-331,13 \mathrm{p}$.

81-345 Johnson, K.G., and Quiñones-Aponte, Vicente, 1982, Flood of September 16, 1975, in the Añasco area, Puerto Rico: U.S. Geological Survey Water-Resources Investigations Open-File Report 81-345, 1 sheet.

81-346 Johnson, K.G., and Carrasquillo, R.A., 1982, Floods of October 9, 1970, and September 16, 1975, at Jayuya, Puerto Rico: U.S. Geological Survey Water-Resources Investigations Open-File Report 81-346, 1 sheet.

81-413 Johnson, K.G., Quiñones, Ferdinand, and Alicea, José, 1982, Flood of September 16, 1975, at Utuado, Puerto Rico: U.S. Geological Survey Water-Resources Investigations Open-File Report 81-413, 1 sheet.

81-480 Johnson, K.G., and González, Ralph, 1982, Flood of September 16, 1975, in the Guánica area, Puerto Rico: U.S. Geological Survey Open-File Report 81-480, 1 sheet.

81-490 Torres-González, Arturo, and Gómez-Gómez, Fernando, 1982, Geohydrologic descriptions of selected solid-waste disposal sites in Puerto Rico: U.S. Geological Survey Open-File Report 81-490, 146 p.

81-626

Colón-Ramos, Héctor, and Colón-Dieppa, Eloy, 1981, Ground-water levels and chloride concentrations in alluvial aquifers on the south coast of Puerto Rico, February 1980: U.S. Geological Survey Open-File Report 81-626, 20 p.

\section{1-641}

81-805

Colón-Dieppa, Eloy, and González, J.R., 1981, Ground-water levels in alluvium on the south coast of Puerto Rico, February 1979: U.S. Geological Survey Open-File Report 81-641, 21 p.

Johnson, K.G., 1982, Flood of September 16, 1975, in the Guanajibo Valley, Puerto Rico: U.S. Geological Survey WaterResources Investigations Open-File Report 81-805, 1 sheet.

82-52

82-82

82-262

Heisel, J.E., González, J.R., and Cruz, Carlos, 1983, Analog model analysis of the north coast limestone aquifers, Puerto Rico: U.S. Geological Survey Open-File Report 82-52, 49 p.

Stevens, K.E., Gómez-Gómez, Fernando, and Alicea, José, 1981, Water wells in the U.S. Virgin Islands, Part 1, St. Thomas: U.S. Geological Survey Open-File Report 82-82, 112 p.

Johnson, K.G., Carrasquillo, R.A., and González, Ralph, 1982, Flood of October 8, 1977, in St. Croix, U.S. Virgin Islands: U.S. Geological Survey Water-Resources Investigations Open-File Report 82-262, 21 p., 3 pls.

82-332

Gómez-Gómez, Fernando, and Guzmán-Ríos, Senén, 1982, Reconnaissance of ground-water quality throughout Puerto Rico, September-October 1981: U.S. Geological Survey Open-File Report 82-332, 1 sheet.

Gómez-Gómez, Fernando, Quiñones, Ferdinand, and Ellis, S.R., 1983, Hydrologic characteristics of lagoons at San Juan, Puerto Rico, during an October 1974 tidal cycle: U.S. Geological Survey Water-Resources Investigations Open-File Report 82-349, 34 p.

83-546 Colón-Ramos, H.M., 1983, Ground-water records for St. Croix, U.S. Virgin Islands, 1969-1973: U.S. Geological Survey OpenFile Data Report 83-546, 28 p.

83-683 Guzmán-Ríos, Senén, 1983, Reconnaissance of the principal springs of Puerto Rico, 1982-83: U.S. Geological Survey Open-File Data Report 83-683, 1 sheet.

Guzmán-Ríos, Senén, and Quiñones-Márquez, Ferdinand, 1984, Ground-water quality at selected sites throughout Puerto Rico, September 1982 - July 1983: U.S. Geological Survey Open-File Data Report 84-058, 1 sheet.

84-126

Gómez-Gómez, Fernando, Quiñones, Ferdinand, and López, Marisol, 1984, Public water supplies in Puerto Rico, 1983: U.S. Geological Survey Open-File Data Report 84-126, 102 p.

Quiñones, Ferdinand, Colón-Dieppa, Eloy, and Juarbe, Max, 1984, Flow duration at streamflow gaging stations in Puerto Rico: U.S. Geological Survey Open-File Data Report 84-127, 93 p.

84-229

Quiñones, Ferdinand, and López, Marisol, 1984, Publications of the U.S. Geological Survey, Water Resources Division for Puerto Rico and the U.S. Virgin Islands, 1946-1984: U.S. Geological Survey Open-File Data Report 84-229, 32 p.

Torres-González, Arturo, and Wolansky, R.M., 1984, Planning report for the comprehensive appraisal of the ground-water resources of the north coast limestone area of Puerto Rico: U.S. Geological Survey Open-File Data Report 84-427, 32 p.

Torres-Sierra, Heriberto, and Dacosta, Rafael, 1984, Estimated water use in St. Thomas, U.S. Virgin Islands, July 1983 - June 1984: U.S. Geological Survey Open-File Data Report 84-721, 1 sheet. 


\section{Numbered Open-File Reports--Continued}

84-810 Guzmán-Ríos, Senén, and Quiñones-Márquez, Ferdinand, 1985, Reconnaissance of trace organic compounds in ground water throughout Puerto Rico, October 1983: U.S. Geological Survey Open-File Data Report 84-810, 1 sheet.

85-414 Quiñones, Ferdinand, and Rivera, Elba, 1985, Publications of the U.S. Geological Survey, Water Resources Division for Puerto Rico and the U.S. Virgin Islands, 1946-1985: U.S. Geological Survey Open-File Data Report 85-414, 21 p.

85-556

Quiñones-Márquez, Ferdinand, and Peña-Cruz, Gilberto, 1985, Water resources investigations in Puerto Rico and the U.S. Virgin Islands - Programs and activities of the U.S. Geological Survey, Water Resources Division, Caribbean District 19841985: U.S. Geological Survey Open-File Report 85-556, 43 p.

Torres-Sierra, Heriberto, and Avilés, Ada, 1986, Estimated water use in Puerto Rico, 1980-82: U.S. Geological Survey OpenFile Data Report 85-557, 77 p.

85-642

86-53

86-241

86-537

87-123

87-533

88-162

88-163

88-324

88-476

88-701

89-257

90-122

90-199

90-365

90-390

91-217

92-126

Quiñones, Ferdinand, and Alicea-Ortíz, José, 1985, Agua subterránea en Puerto Rico: U.S. Geological Survey Open-File Report $85-642,6$ p.

Román-Más, Angel, and Green, Bruce, 1987, Climatological data for the rice-growing areas along the north coast of Puerto Rico: U.S. Geological Survey Open-File Data Report 86-53, 90 p.

Quiñones, Ferdinand, Meléndez, Frank, and Bonnet, Carlos, 1989, Sedimentation survey of Lago Dos Bocas, Puerto Rico, June 1985: U.S. Geological Survey Open-File Report 86-241, 14 p.

Torres-Sierra, Heriberto, 1987, Estimated water use in St. Croix, U.S. Virgin Islands, October 1983 - September 1985: U.S. Geological Survey Open-File Data Report 86-537, 1 sheet.

Quiñones, Ferdinand, and Johnson, K.G., 1987, The floods of May 17-18, 1985 and October 6-7, 1985 in Puerto Rico: U.S. Geological Survey Open-File Report 87-123, 22 p.

Román-Más, Angel, and Ramos-Ginés, Orlando, 1988, Compilation of water-quality data for the north coast limestone aquifers, Puerto Rico, 1951 to 1987: U.S. Geological Survey Open-File Data Report 87-533, 133 p.

Troester, J.W., 1988, U.S. Geological Survey ground-water studies in Puerto Rico: U.S. Geological Survey Water Fact Sheet, Open-File Report 88-162, 2 p.

Troester, J.W., 1988, U.S. Geological Survey ground-water studies in the U.S. Virgin Islands: U.S. Geological Survey Water Fact Sheet, Open-File Report 88-163, 2 p.

Guzmán-Ríos, Senén, 1989, Suspended-sediment data in the upper Río Grande de Loíza basin, Puerto Rico: U.S. Geological Survey Open-File Data Report 88-324, 42 p.

Peck, D.L., Troester, J.W., and Moore, J.E., 1988, Karst hydrogeology in the United States of America: U.S. Geological Survey Open-File Report 88-476, 19 p.

Torres-González, Sigfredo, 1991, Compilation of ground-water level measurements obtained by the United States Geological Survey in Puerto Rico, 1958-1985: U.S. Geological Survey Open-File Data Report 88-701, 163 p.

Guariguata, M.R., and Larsen, M.C., 1990, Preliminary map showing locations of landslides in El Yunque quadrangle, Puerto Rico: U.S. Geological Survey Open-File Report 89-257, 1 sheet.

Veve, T.D., and Troester, J.W., 1990, Water-resources investigations in Puerto Rico and the U.S. Virgin Islands, 1986-1988: U.S. Geologic Survey Open-File Report 90-122, 39 p.

Figueroa-Alamo, Carlos, 1991, Sedimentation survey of Lago Toa Vaca, Puerto Rico, July 1985: U.S. Geological Survey OpenFile Report 90-199, 9 p.

Renken, R.A., Díaz, Pedro, Gómez-Gómez, Fernando, and Quiñones-Aponte, Vicente, 1990, Hydrologic excursion to Puerto Rico's Southern Plain: U.S. Geological Survey Open-File Report 90-365, 24 p., 1 pl.

Rodríguez-Martínez, Jesús, Hartley, J.L., and Torres-González, Arturo, 1991, Geologic and hydrologic data collected at test well NC-5, Barceloneta, Puerto Rico: U.S. Geological Survey Open-File Report 90-390, 30 p.

Rodríguez-Martínez, Jesús, Scharlach, R.A., and Torres-González, Arturo, 1991, Geologic and hydrologic data collected at test holes NC-1 and NC-3, Guaynabo and San Juan, eastern Puerto Rico: U.S. Geological Survey Open-File Report 91-217, $20 \mathrm{p}$.

Rodríguez-Martínez, Jesús, Scharlach, R.A., and Torres-González, Arturo, 1992, Geologic and hydrologic data collected at test holes NC-4 and NC-14, Manati and Vega Baja, Puerto Rico: U.S. Geological Survey Open-File Report 92-126, 18 p. 


\section{Unnumbered Open-File Reports}

Anders, R.B., 1968, Reconnaissance of the water resources of the Central Guanajibo Valley, Cabo Rojo, Puerto Rico: U.S. Geological Survey Open-File Report, 15 p.

Díaz, J.R., 1973, Chemical quality of water in Caño Tiburones, Puerto Rico: A reconnaissance study carried out in 1967: U.S. Geological Survey Open-File Report Map Series no. 2, 2 pls.

Grossman, I.G., 1959, Ground-water data from St. Thomas, Virgin Islands: U.S. Geological Survey Open-File Report, 35 p., 5 pls.

Haire, W.J., 1971, Flooding along the Río Piedras in the San Juan area, Puerto Rico: U.S. Geological Survey Hydrologic Investigations Map Series no. 1, 2 sheets.

Hendrickson, G.E., 1962, Development of the ground-water resources of St. Croix, Virgin Islands: U.S. Geological Survey Open-File Report, 84 p.

López, M.A., and Fields, F.K., 1970, A proposed streamflow-data program for Puerto Rico: U.S. Geological Survey Open-File Report, 42 p.

McGuinness, C.L., 1946, Ground-water reconnaissance of Vieques Island, Puerto Rico: U.S. Geological Survey Open-File Report.

McGuinness, C.L., 1946, Records of wells in Puerto Rico: U.S. Geological Survey Open-File Report, 267 p.

McGuinness, C.L., 1948, Ground-water resources of Puerto Rico: U.S. Geological Survey Open-File Report, 277 p.

McGuinness, C.L., 1953, Summary of the water resources of the Virgin Islands: U.S. Geological Survey Open-File Report, 8 p.

Quiñones, Ferdinand, and Alicea, José, 1981, Water resources investigations in Puerto Rico and the U.S. Virgin Islands - Programs and activities of the U.S. Geological Survey, Water Resources Division, Caribbean District: U.S. Geological Survey Open-File Report, 69 p.

Quiñones, Ferdinand, and Alicea, José, 1983, Water resources investigations in Puerto Rico and the U.S. Virgin Islands -Programs and activities of the U.S. Geological Survey, Water Resources Division, Caribbean District: U.S. Geological Survey Open-File Report, 28 p.

Quiñones, Ferdinand, and Alicea, José, 1984, Water resources investigations in Puerto Rico and the U.S. Virgin Islands -Programs and activities of the U.S. Geological Survey, Water Resources Division, Caribbean District: U.S. Geological Survey Open-File Report, 41 p.

Quiñones-Márquez, Ferdinand, 1973, Chemical-quality and flow-duration curves for selected streams in Puerto Rico: U.S. Geological Survey Open-File Report PR-7.

Quiñones-Márquez, Ferdinand, 1981, Frecuencia de magnitud y flujos en los ríos principales de Puerto Rico: U.S. Geological Survey Open-File Data Report.

Quiñones-Márquez, Ferdinand, 1981, Ground-water levels in the south coast of Puerto Rico, February 1969-71: U.S. Geological Survey OpenFile Data Report PR-1-71.

Robison, T.M., 1972, Ground water in central St. Croix, U.S. Virgin Islands: U.S. Geological Survey Open-File Report, 18 p.

Vaughan, T.W., 1920, The ground-water resources of the West Indian Islands, St. John, St. Thomas, Culebra and Vieques, and of the eastern end of Puerto Rico: U.S. Geological Survey Open-File Report.

Ward, P.E., and Jordan, D.G., 1963, Water resources of the Virgin Islands, A preliminary appraisal, 1963: U.S. Geological Survey Open-File Report, 44 p.

\section{Professional Papers}

Professional Papers are mainly comprehensive scientific reports of significant and lasting scientific interest. Included are reports on the results of resource studies, and of topographic, hydrologic, and geologic investigations. They also include collections of related papers addressing different aspects of a single scientific topic.

424-C Arnow, Ted, 1961, Water bearing properties of the rocks in the Arecibo-Barceloneta area, Puerto Rico: in Short Papers in the Geologic and Hydrologic Sciences, Articles 147-292, Geological Survey Research 1961, U.S. Geological Survey Professional Paper 424-C, Article 221, p. 201-202.

424-C Grossman, I.G., 1961, Ground-water conditions in the lower Tallaboa Valley, Puerto Rico: in Short Papers in the Geologic and Hydrologic Sciences, Articles 147-292, U.S. Geological Survey Professional Paper 424-C, Article 222, p. $202-203$.

450-B

Grossman, I.G., 1962, Chemical quality of ground water in St. Thomas, Virgin Islands: in Short Papers in Geology, Hydrology, and Topography, Articles 1-59, U.S. Geological Survey Professional Paper 450-B, Article 55, p. 131-133. 


\section{Professional Papers--Continued}

450-D Grossman, I.G., 1962, Stratigraphy and hydrology of the Juana Díaz Formation in the Yauco area, Puerto Rico: in Short Papers in Geology, Hydrology, and Topography, Articles 120-179: U.S. Geological Survey Professional Paper 450-D, Article 137, p. 62-63.

475-B Grossman, I.G., 1963, Geology of the Guánica-Guayanilla bay area, southwestern Puerto Rico: in Short Papers in Geology and Hydrology, Articles 1-59, U.S. Geological Survey Professional Paper 475-B, Article 29, p. 114-116.

550-C McClymonds, N.E., and Ward, P.E., 1966, Hydrologic characteristics of the alluvial fan near Salinas, Puerto Rico: in Geological Survey Research 1966, Chap. C, U.S. Geological Survey Professional Paper 550-C, p. 231-234.

750-B Giusti, E.V., 1971, Regional specific yield of the Coamo Fan, Puerto Rico, computed by the water budget method: in Geological Survey Research 1971, Chap. B, U.S. Geological Survey Professional Paper 750-B, p. 248-251.

750-B Robison, T.M., 1971, Earthquake-accelerated decline of water level in an observation well in St. Thomas, Virgin Islands: U.S. Geological Survey Professional Paper 750-B, p. 252-253.

750-D Bennett, G.D., and Giusti, E.V., 1971, Coastal ground-water flow near Ponce, Puerto Rico: in Geological Survey Research 1971, Chap. D, U.S. Geological Survey Professional Paper 750-D, p. 206-211.

800-D Jordan, D.G., 1972, Land-use effect on the water regimen of the U.S. Virgin Islands: in Geological Survey Research 1972, Chap. D: U.S. Geological Survey Professional Paper 800-D, p. 211-216.

813-U Gómez-Gómez, Fernando, and Heisel, J.E., 1980, Summary appraisals of the Nation's ground-water resources - Caribbean Region: U.S. Geological Survey Professional Paper 813-U, 32 p., 2 pls.

Monroe, W.H., 1976, The karst landforms of Puerto Rico: U.S. Geological Survey Professional Paper 899, 69 p., 1 pI.

Monroe, W.H., 1980, Geology of the middle Tertiary Formations of Puerto Rico: U.S. Geological Survey Professional Paper 953, 93 p., 1 pl.

1012

Giusti, E.V., 1978, Hydrogeology of the karst of Puerto Rico: U.S. Geological Survey Professional Paper 1012, 68 p., 2 pls.

1159

Monroe, W.H., 1980, Some tropical landforms of Puerto Rico: U.S. Geological Survey Professional Paper 1159,39 p., 1 pl.

\section{Water-Resources Bulletins (USGS)}

Bulletins contain significant data and interpretations that are of lasting scientific interest but are generally more limited in scope or geographic coverage than professional papers. They include the results of resource studies and of geologic and topographic investigations; as well as collections of short papers related to a specific topic.

Bogart, D.B., Arnow, Ted, and Crooks, J.W., 1960, Water problems of Puerto Rico and a program of water-resources investigations: U.S. Geological Survey Water-Resources Bulletin 1, 40 p.

Arnow, Ted, and Crooks, J.W., 1960, Public water supplies in Puerto Rico: U.S. Geological Survey Water-Resources Bulletin 2, $34 \mathrm{p}$.

Ward, P.E., and Truxes, C.S., 1964, Water wells in Puerto Rico: U.S. Geological Survey Water-Resources Bulletin 3, 249 p.

Bogart, D.B., Arnow, Ted, and Crooks, J.W., 1964, Water resources of Puerto Rico - A progress report: U.S. Geological Survey Water-Resources Bulletin 4, 120 p.

Crooks, J.W., Grossman, I.G., and Bogart, D.B., 1968, Water resources of the Guayanilla-Yauco area, Puerto Rico: U.S. Geological Survey Water-Resources Bulletin 5, 55 p.

McClymonds, N.E., 1967, Water resources of the Guánica area, Puerto Rico - A preliminary appraisal, 1963: U.S. Geological Survey Water-Resources Bulletin 6,43 p.

Grossman, I.G., Bogart, D.B., Crooks, J.W., and Díaz, J.R., 1972, Water resources of the Tallaboa Valley, Puerto Rico: U.S. Geological Survey Water-Resources Bulletin 7, 115 p.

Giusti, E.V., 1968, Water resources of the Juana Díaz area, Puerto Rico - A preliminary appraisal, 1966: U.S. Geological Survey Water- Resources Bulletin 8, 43 p.

Giusti, E.V., 1971, Water resources of the Coamo area, Puerto Rico: U.S. Geological Survey Water-Resources Bulletin 9, 31 p.

Bennett, G.D., and Giusti, E.V., 1972, Ground water in the Tortuguero area, Puerto Rico - As related to proposed harbor construction: U.S. Geological Survey Water-Resources Bulletin 10, 25 p. 


\section{Water-Resources Bulletins (USGS)--Continued}

11

12

13

14

Bennett, G.D., 1972, Ground water along Río Bucaná at Ponce, Puerto Rico - And the effects of a proposed floodway on groundwater quality: U.S. Geological Survey Water-Resources Bulletin 11, 29 p.

Haire, W.J., 1972, Flood of October 5-10, 1970 in Puerto Rico: U.S. Geological Survey Water-Resources Bulletin 12, 38 p.

McClymonds, N.E., and Díaz, J.R., 1972, Water resources of the Jobos area, Puerto Rico - A preliminary appraisal, 1962: U.S. Geological Survey Water-Resources Bulletin 13, 32 p.

McClymonds, N.E., 1972, Water resources of the Ponce area, Puerto Rico: U.S. Geological Survey Water-Resources Bulletin 14, $26 \mathrm{p}$.

\section{Water-Resources Investigations Reports}

Water-Resources Investigations Reports are of an interpretative nature made available to the public in hydrologic information, mainly of local interest, intended for quick release.

75-38 Ellis, S.R., and Gómez-Gómez, Fernando, 1976, Hydrologic characteristics of lagoons at San Juan, Puerto Rico, during a January 1974 tidal cycle: U.S. Geological Survey Water-Resources Investigations Report 75-38, 45 p.

75-41 Anderson, H.R., 1976, Ground water in the San Juan Metropolitan area, Puerto Rico: U.S. Geological Survey Water-Resources Investigations Report 75-41, $34 \mathrm{p}$.

75-42 Giusti, E.V., and Bennett, G.D., 1976, Water resources of the north coast limestone area, Puerto Rico: U.S. Geological Survey Water-Resources Investigations Report 75-42, 42 p.

76-3 Jordan, D.G., and Gilbert, B.K., 1976, Water supply and waste disposal, Culebra, Puerto Rico: U.S. Geological Survey WaterResources Investigations 76-3, $31 \mathrm{p}$.

Ellis, S.R., 1976, History of dredging and filling of lagoons in the San Juan area, Puerto Rico: U.S. Geological Survey WaterResources Investigations Report 76-38, 25 p., 4 pls.

76-68

Anderson, H.R., 1977, Ground water in the Lajas Valley, Puerto Rico: U.S. Geological Survey Water-Resources Investigations Report 68-76, $45 \mathrm{p}$.

76-91

76-115

77-122

Haire, W.J., and Johnson, K.G., 1977, Floods of November 12, 1974, in the Charlotte Amalie area, St. Thomas, U.S. Virgin Islands: U.S. Geological Survey Water-Resources Investigations Report 76-91, 3 sheets.

Adolphson, D.G., Seijo, M.A., and Robison, T.M., 1977, Water resources of the Maunabo Valley, Puerto Rico: U.S. Geological Survey Water-Resources Investigations Report 115-76, $38 \mathrm{p}$.

\section{8-58}

78-141

Quiñones-Márquez, Ferdinand, and Fusté, L.A., 1978, Limnology of Laguna Tortuguero, Puerto Rico: U.S. Geological Survey Water-Resources Investigations Report 77-122, 86 p.

Haire, W.J., and Johnson, K.G., 1978, Floods of November 11-13, 1974, in St. Croix, U.S. Virgin Islands: U.S. Geological Survey Water-Resources Investigations Report 77-136, 11 sheets.

Heisel, J.E., and González, J.R., 1979, Water budget and hydraulic aspects of artificial recharge, south coast of Puerto Rico: U.S. Geological Survey Water-Resources Investigations Report 78-58, 102 p.

López, M.A., Colón-Dieppa, Eloy, and Cobb, E.D., 1979, Floods in Puerto Rico, magnitude and frequency: U.S. Geological Survey Water-Resources Investigations Report 78-141, 68 p.

Quiñones-Márquez, Ferdinand, 1980, Limnology of Lago Loíza, Puerto Rico: U.S. Geological Survey Water-Resources Investigations Report 79-97, $113 \mathrm{p}$.

Johnson, K.G., 1982, Flood of September 16, 1975, in the Guayanilla Valley, Puerto Rico: U.S. Geological Survey WaterResources Investigations Open-File Report 80-1282, 1 sheet.

Johnson, K.G., 1981, Flood of September 16, 1975, in Tallaboa Valley, Puerto Rico: U.S. Geological Survey Water-Resources Investigations Open-File Report 80-1283, 5 sheets.

\section{1-345}

Johnson, K.G., 1982, Flood of September 16, 1975, in the Yauco Valley, Puerto Rico: U.S. Geological Survey Open-File Report 81-331, $13 \mathrm{p}$.

Johnson, K.G., and Quiñones-Aponte, Vicente, 1982, Flood of September 16, 1975, in the Añasco area, Puerto Rico: U.S. Geological Survey Water-Resources Investigations Open-File Report 81-345, 1 sheet.

Johnson, K.G., and Carrasquillo, R.A., 1982, Floods of October 9, 1970, and September 16, 1975, at Jayuya, Puerto Rico: U.S. Geological Survey Water-Resources Investigations Open-File Report 81-346, 1 sheet.

Johnson, K.G., Quiñones, Ferdinand, and Alicea, José, 1982, Flood of September 16, 1975, at Utuado, Puerto Rico: U.S. Geological Survey Water-Resources Investigations Open-File Report 81-413, 1 pl. 


\section{Water-Resources Investigations Reports--Continued}

81-480 Johnson, K.G., and González, Ralph, 1982, Flood of September 16, 1975, in the Guánica area, Puerto Rico: U.S. Geological Survey Open-File Report 81-480, 1 sheet.

81-805 Johnson, K.G., 1982, Flood of September 16, 1975, in the Guanajibo Valley, Puerto Rico: U.S. Geological Survey WaterResources Investigations Open-File Report 81-805, 1 sheet.

82-262 Johnson, K.G., Carrasquillo, R.A., and González, Ralph, 1982, Flood of October 8, 1977, in St. Croix, U.S. Virgin Islands: U.S. Geological Survey Water-Resources Investigations Open-File Report 82-262, 21 p., 3 pls.

82-4050 Colón-Dieppa, Eloy, and Quiñones-Márquez, Ferdinand, 1985, A reconnaissance of the water resources of the Central Río Guanajibo Valley, Puerto Rico: U.S. Geological Survey Water-Resources Investigations Report 82-4050, 47 p.

82-4115 Torres-González, Arturo, and Díaz, J.R., 1984, Water resources of the Sabana Seca to Vega Baja area, Puerto Rico: U.S. Geological Survey Water-Resources Investigations Report 82-4115, 53 p.

83-4055 McKinley, P.W., 1985, Surface water data network analysis for Puerto Rico: U.S. Geological Survey Water-Resources Investigations Report 83-4055, 14 p.

83-4071 Zack, A.L., and Class-Cacho, Angel, 1984, Restoration of freshwater in the Caño Tiburones area, Puerto Rico: U.S. Geological Survey Water-Resources Investigations Report 83-4071, 33 p., 1 pl.

83-4199 Gómez-Gómez, Fernando, 1984, Water resources of the lower Río Grande de Manatí Valley: U.S. Geological Survey WaterResources Investigations Report 83-4199, 42 p.

83-4266 Torres-González, Arturo, 1985, Use of surface-geophysical techniques for ground-water exploration in the Canóvanas-Río Grande area, Puerto Rico: U.S. Geological Survey Water-Resources Investigations Report 83-4266, 29 p.

84-4089 Colón-Dieppa, Eloy, and Quiñones-Aponte, Vicente, 1985, Estimates of 7-day, 10-year low flow at ungaged streams in Puerto Rico: U.S. Geological Survey Water-Resources Investigations Report 84-4089, 2 sheets.

84-4113 Torres-González, Arturo, 1985, Simulation of ground-water flow in the water table aquifer near Barceloneta, Puerto Rico: U.S. Geological Survey Water-Resources Investigations Report 84-4113, 39 p.

84-4184 Curtis, R.E., Jr., 1984, Floods of April 18, 1983 on St. Thomas and St. John, U.S. Virgin Islands: U.S. Geological Survey WaterResources Investigations Report 84-4184, 1 sheet.

85-89 Quiñones-Márquez, Ferdinand, Guzmán-Ríos, Senén, 1986, Determinación de caudal y técnicas de muestreo en agua superficial: U.S. Geological Survey Water-Resources Investigations Report 85-89, 68 p.

85-4160 Quiñones-Aponte, Vicente, 1986, Water resources of the lower Río Grande de Arecibo alluvial valley, Puerto Rico: U.S. Geological Survey Water-Resources Investigations Report 85-4160, 38 p., 1 pl.

85-4179 Quiñones-Aponte, Vicente, 1986, Simulation of ground-water flow in the Río Yauco alluvial valley, Yauco, Puerto Rico: U.S. Geological Survey Water-Resources Investigations Report 85-4179, 32 p.

85-4237 Díaz, J.R., and Jordan, D.G., 1987, Water resources of the Río Grande de Añasco - lower valley, Puerto Rico: U.S. Geological Survey Water-Resources Investigations Report 85-4237, 48 p.

$85-4268$

Torres-Sierra, Heriberto, 1985, Potentiometric surface of the upper limestone aquifer in the Dorado-Vega Alta area, north-central Puerto Rico, February 1983: U.S. Geological Survey Water-Resources Investigations Report 85-4268, 1 sheet.

85-4269 Guzmán-Ríos, Senén, 1988, Hydrology and water quality of the principal springs in Puerto Rico: U.S. Geological Survey WaterResources Investigations Report 85-4269, 30 p.

86-4074 Gómez-Gómez, Fernando, 1987, Planning report for the Caribbean Islands Regional Aquifer-System Analysis project: U.S. Geological Survey Water-Resources Investigations Report 86-4074, 50 p., 3 pls.

86-4080 Román-Más, Angel, and Lee, R.W., 1987, Geochemical evolution of waters within the north coast limestone aquifers of Puerto Rico: A conceptualization based on a flow path in the Barceloneta area: U.S. Geological Survey Water-Resources Investigations Report 86-4080, 28 p.

86-4100 Torres-González, Sigfredo, 1989, Reconnaissance of the ground-water resources of Vieques Island, Puerto Rico: U.S. Geological Survey Water-Resources Investigations Report 86-4100, 37 p.

86-4334 Román-Más, Angel, 1988, Water required, water used, and potential water sources for rice irrigation, north coast of Puerto Rico: U.S. Geological Survey Water-Resources Investigations Report 86-4334, 35 p.

87-4019 Quiñones, Ferdinand, Green, Bruce, and Santiago, Luis, 1989, Sedimentation survey of Lago Loíza, Puerto Rico, July 1985: U.S. Geological Survey Water-Resources Investigations Report 87-4019, 17 p.

87-4039 Johnson, K.G., Quiñones, Ferdinand, and González, Ralph, 1987, Hydraulic analyses of water-surface profiles in the vicinity of the Coamo Dam and Highway 52 bridge, southern Puerto Rico; Flood analyses as related to the flood of October 7, 1985: U.S. Geological Survey Water-Resources Investigations Report 87-4039, 26 p. 


\section{Water-Resources Investigations Reports--Continued}

87-4088 Graves, R.P., 1989, Water resources of the Humacao-Naguabo area, eastern Puerto Rico: U.S. Geological Survey WaterResources Investigations Report 87-4088, 69 p.

87-4105 Fernando, and Torres-Sierra, Heriberto, 1988, Hydrology and effects of development on the water-table aquifer in the Vega Alta quadrangle, Puerto Rico: U.S. Geological Survey Water-Resources Investigations Report 87-4105, 54 p.

$87-4123$

Román-Más, Angel, and Ramos-Ginés, Orlando, 1987, Elevation of the water-table surface for the alluvial aquifer and hydrologic conditions in the Santa Isabel-Juana Díaz area, Puerto Rico, March 1986: U.S. Geological Survey Water-Resources Investigations Report 87-4123, 2 sheets.

Torres-González, Sigfredo, and Gómez-Gómez, Fernando, 1987, Potentiometric surface of the alluvial aquifer and hydrologic conditions in the Central Aguirre quadrangle, Puerto Rico, March 1986: U.S. Geological Survey Water-Resources Investigations Report 87-4160, 1 sheet.

$87-4161$

Quiñones-Aponte, Vicente, and Gómez-Gómez, Fernando, 1987, Potentiometric surface of the alluvial aquifer and hydrologic conditions in the Salinas quadrangle, Puerto Rico, March 1986: U.S. Geological Survey Water-Resources Investigations Report $87-4161,1$ sheet.

Dacosta, Rafael, and Gómez-Gómez, Fernando, 1987, Potentiometric surface of the alluvial aquifer and hydrologic conditions in the Guayama quadrangle, Puerto Rico, March 1986: U.S. Geological Survey Water-Resources Investigations Report 87-4162, 1 sheet.

88-4037

Quiñones-Aponte, Vicente, Whitesides, D.V., and Zack, Allen, 1989, Single-well injection and recovery of freshwater from an aquifer containing saline water at Arecibo, Puerto Rico: U.S. Geological Survey Water-Resources Investigations Report 88$4037,19 \mathrm{p}$.

88-4131 Graves, R.P., and González, Ralph, 1988, Potentiometric surface of the Turpentine Run basin aquifer in the Tutu area, eastern St. Thomas, U.S. Virgin Islands, September 11, 1987: U.S. Geological Survey Water-Resources Investigations Report 88-4131, 1 sheet.

89-1989 Puig, J.C., Rodríguez-del-Río, Félix, and Rodríguez, J.M., 1989, Potentiometric surface of the alluvial aquifer and hydrologic conditions near Caguas, Puerto Rico, March 1988: U.S. Geological Survey Water-Resources Investigations Report 89-4075, 1 sheet.

$89-4085$

Torres-González, Sigfredo, and Rodríguez-del-Río, Félix, 1990, Potentiometric surface of the Kingshill aquifer and hydrologic conditions, St. Croix, U.S. Virgin Islands, July 1987: U.S. Geological Survey Water-Resources Investigations Report 89-4085, 1 sheet.

89-4115

Rodríguez-del-Río, Félix, and Quiñones-Aponte, Vicente, 1990, Potentiometric surface of the principal aquifer and hydrologic conditions in the Ponce-Juana Díaz area, Puerto Rico, April to May 1987: U.S. Geological Survey Water-Resources Investigations Report 89-4115, 1 sheet.

89-4116 Rodríguez-del-Río, Félix, and Gómez-Gómez, Fernando, 1990, Potentiometric surface of the alluvial aquifer and hydrologic conditions in the Santa Isabel-Juana Díaz area, Puerto Rico, March to April 1987: U.S. Geological Survey Water-Resources Investigations Report 89-4116, 1 sheet.

89-4182 Graves, R.P., 1991, Ground-water resources in Lajas Valley, Puerto Rico: U.S. Geological Survey Water-Resources Investigations Report 89-4182, 55 p.

90-4059

Puig, J.C., and Rodríguez, J.M., 1990, Potentiometric surface of the alluvial aquifer and hydrologic conditions near Gurabo and Juncos, Puerto Rico, March 1988: U.S. Geological Survey Water-Resources Investigations Report 90-4059, 2 sheets.

90-4088 Reid, Ken, 1991, Cost-effectiveness of the stream-gaging program in Puerto Rico and the U.S. Virgin Islands: U.S. Geological Survey Water-Resources Investigations Report 90-4088, 32 p.

90-4125 Ramos-Ginés, Orlando, 1991, Elevation of water table and hydrologic conditions in the Río Lapa to Río Majada area, Puerto Rico, for December 1988, and April, July, and October 1989: U.S. Geological Survey Water-Resources Investigations Report 90-4125, 4 p., 1 sheet.

91-4079 Puig, J.C., and Rodríguez, J.M., 1992, Ground-water resources of the Caguas-Juncos Valley, Puerto Rico: U.S. Geological Survey Water-Resources Investigations Report 91-4079, 48 p.

91-4124 Graves, R.P., 1992, Geohydrology of the Aguirre and Pozo Hondo areas, southern Puerto Rico: U.S. Geological Survey WaterResources Investigations Report 91-4124, 43 p.

91-4162 Sépulveda, Nicasio, 1992, Computer algorithm for the analysis of underdamped and overdamped water-level responses in slug tests: U.S. Geological Survey Water Resources-Investigations Report 91-4162, 20 p.

92-4063 Santiago-Rivera, Luis, 1992, Low-flow characteristics at selected sites on streams in eastern Puerto Rico: U.S. Geological Survey Water-Resources Investigations Report 92-4063, 46 p. 


\section{Water-Supply Papers}

Water-Supply Papers include reports on all aspects of hydrology, including quality, recoverability, and use of water resources. They include also several series of statistical reports on streamflow, floods, ground-water levels, and water quality; and collections of short papers on related topics.

32

1067

1460-A

1547

1663-D

1663-I

1786

2250

Wilson, H.M., 1899, Water resources of Puerto Rico: U.S. Geological Survey Water-Supply Paper 32.

Cederstrom, D.J., 1950, Geology and ground-water resources of St. Croix, Virgin Islands: U.S. Geological Survey Water-Supply Paper 1067, 117 p., 1 pl.

Lohr, E.W., 1957, Chemical character of public water supplies of the larger cities in Alaska, Hawaii, and Puerto Rico, 1954: U.S. Geological Survey Water-Supply Paper 1460-A, 39 p., 1 pl.

Harris, K.F., 1962, Inventory of published and unpublished sediment-load data, United States and Puerto Rico, 1950-60: U.S. Geological Survey Water-Supply Paper 1547, 117 p.

Hendrickson, G.E., 1963, Ground water for public supply in St. Croix, Virgin Islands: U.S. Geological Survey Water-Supply Paper 1663-D, 27 p.

Jordan, D.G., and Fisher, D.W., 1977, Relation of bulk precipitation and evaporation to water quality and water resources, St. Thomas, Virgin Islands: U.S. Geological Survey Water-Supply Paper 1663-I, 30 p.

Woodward, T.H., and Heidel, S.G., 1964, Inventory of published and unpublished chemical analyses of surface waters in the continental United States and Puerto Rico, 1961: U.S. Geological Survey Water-Supply Paper 1786, 490 p.

U.S. Geological Survey, 1983, Puerto Rico and the U.S. Virgin Islands water issues: National Water Summary 1983 - Hydrologic Events and Issues, U.S. Geological Survey Water-Supply Paper 2250, p. 200-202.

Zack, A.L., 1985, Effects of sand removal on the Camuy Mangrove Forest, Puerto Rico: U.S. Geological Survey Water-Supply Paper 2254.

Gómez-Gómez, Fernando, Quiñones-Márquez, Ferdinand, and Zack, A.L., 1984, U.S. Virgin Islands ground-water resources National Water Summary 1984: U.S. Geological Survey Water-Supply Paper 2275, p. 409-413.

Quiñones-Márquez, Ferdinand, Gómez-Gómez, Fernando, and Zack, Allen, 1984, Puerto Rico ground-water resources National Water Summary 1984: U.S. Geological Survey Water-Supply Paper 2275, p. 367-372.

Colón-Dieppa, Eloy, 1986, Puerto Rico surface-water resources - National Water Summary 1985: U.S. Geological Survey WaterSupply Paper 2300, p. 399-406.

Santiago-Rivera, Luis, and Colón-Dieppa, Eloy, 1986, U.S. Virgin Islands surface-water resources - National Water Summary 1985: U.S. Geological Survey Water-Supply Paper 2300, p. 447-452.

Zack, A.L., Rodríguez-Alonso, Teresita, and Román-Más, Angel, 1987, Puerto Rico ground-water quality - National Water Summary: U.S. Geological Survey Water-Supply Paper 2325, p. 437-442.

Zack, A.L., Rodríguez-Alonso, Teresita, and Román-Más, Angel, 1987, U.S. Virgin Islands ground-water quality - National Water Summary: U.S. Geological Survey Water-Supply Paper 2325, p. 489-492.

Zack, A.L., 1988, A well system to recover usable water from a freshwater-saltwater aquifer in Puerto Rico: U.S. Geological Survey Water-Supply Paper 2328, 15 p.

Colón-Dieppa, Eloy, and Torres-Sierra, Heriberto, 1991, Puerto Rico floods and droughts - National Water Summary 1988-89: U.S. Geological Survey Water-Supply Paper 2375, p. 475-482.

Colón-Dieppa, Eloy, Torres-Sierra, Heriberto, and Ortíz, Jorge, 1991, U.S. Virgin Islands floods and droughts - National Water Summary 1988-89: U.S. Geological Survey Water-Supply Paper 2375, p. 521-526.

Schuck-Kolben, R.E., and Kaufman, Lionel, 1991, Storm-surge flooding by Hurricane Hugo on the U.S. Virgin Islands, Puerto Rico, and South Carolina, September 1989 - National Water Summary 1988-89: U.S. Geological Survey Water-Supply Paper 2375 , p. 59-64. 


\section{WATER-DATA REPORTS}

The annual hydrologic data reports of Puerto Rico and the U.S. Virgin Islands are of a series of annual reports that document hydrologic data gathered from the U.S. Geological Survey's surface-and ground-water data-collection networks in each state, Puerto Rico, the U.S. Virgin Islands, and the other Trust Territories. These data, accumulated during many water years, constitute a valuable data base for developing an improved understanding of the water resources of the area.

Water-resources data for Puerto Rico for calendar years 1958-67 were released in a series of reports entitled "Water Records of Puerto Rico." Water-resources data for the U.S. Virgin Islands for the calendar years 1962-69 were released in a report entitled "Water Records of U.S. Virgin Islands." Included were records of streamflow, ground-water levels, and water-quality data for both surface and ground water.

Beginning with the 1968 calendar year, surface-water records for Puerto Rico were released separately on an annual basis. Ground-water level records and water-quality data for surface and ground water were released in companion reports covering periods of several years. Data for the 1973-74 reports were published under separate covers. Water-resources data reports for $1975-76,1977,1978,1979-80,1981-82,1983,1984,1985,1986,1987,1988,1989,1990$, and 1991 water years consist of one volume each and contain data for streamflow, water quality, and ground water.

Publications similar to these reports are published annually by the U.S. Geological Survey for all States. These official Survey reports have an identification number consisting of the two-letter State abbreviation, the last two digits of the water year, and the volume number. For example, the most recent volume is identified as "U.S. Geological Survey Water-Data Report PR-901." These water-data reports are for sale in paper copy or in microfiche by the National Technical Information Service, U.S. Department of Commerce, Springfield, Virginia, 22161, (Curtis and others, 1991).

Colón-Dieppa, Eloy, Díaz, P.L., and García, René, 1987, Water resources data Puerto Rico and the U.S. Virgin Islands, Water Year 1985: U.S. Geological Survey Water-Data Report PR-85-1, 400 p.

Curtis, R.E., Jr., Aquino, Zaida, Díaz, P.L., and García, René, 1988, Water resources data Puerto Rico and the U.S. Virgin Islands, Water Year 1986: U.S. Geological Survey Water-Data Report PR-86-1, 362 p.

Curtis, R.E., Jr., Aquino, Zaida, Díaz, P.L., and Vachier, Ricardo, 1989, Water resources data Puerto Rico and the U.S. Virgin Islands, Water Year 1987: U.S. Geological Survey Water-Data Report PR-87-1, 356 p.

Curtis, R.E., Jr., Aquino, Zaida, Díaz, P.L., and Vachier, Ricardo, 1989, Water resources data for Puerto Rico and the U.S. Virgin Islands, Water Year 1988: U.S. Geological Survey Water-Data Report PR-88-1, 460 p.

Curtis, R.E., Jr., Aquino, Zaida, Díaz, P.L., and Vachier, Ricardo, 1990, Water resources data for Puerto Rico and the U.S. Virgin Islands, Water Year 1989: U.S. Geological Survey Water-Data Report PR-89-1, 419 p.

Curtis, R.E., Jr., Aquino, Zaida, Díaz, P.L., and Vachier, Ricardo, 1991, Water resources data for Puerto Rico and the U.S. Virgin Islands, Water Year 1990: U.S. Geological Survey Water-Data Report PR-90-1, 514 p.

Curtis, R.E., Jr., Guzmán-Ríos, Senén, and Díaz, P.L., 1984, Water resources data Puerto Rico and the U.S. Virgin Islands, Water Year 1983: U.S. Geological Survey Water-Data Report PR-83-1, 302 p.

Curtis, R.E., Jr., Guzmán-Ríos, Senén, and Díaz, P.L., 1985, Water resources data Puerto Rico and the U.S. Virgin Islands, Water Year 1984: U.S. Geological Survey Water-Data Report PR-84-1, 374 p.

Curtis, R.E., Jr., McKinley P.W., and Colón-Ramos, H.M., 1983, Water resources data Puerto Rico, Water Years 1981-82: U.S. Geological Survey Water-Data Report PR-81-82-1, 414 p.

Kipple, F.P., and others, 1968, Water records of Puerto Rico, 1958-63: U.S. Geological Survey Water-Data Report, 353 p.

Rickler, J.G., and others, 1970, Water records of Puerto Rico, 1964-67, Volume 1, north and northeast slopes: U.S. Geological Survey WaterData Report 71-238, 265 p.

Rickler, J.G., and others, 1970, Water records of Puerto Rico, 1964-67, Volume 2, south and west slopes: U.S. Geological Survey Water-Data Report, $308 \mathrm{p}$.

Robison, T.M., and others, 1972, Water records of the U.S. Virgin Islands, 1962-69: U.S. Geological Survey Water-Data Report, 163 p.

U.S. Geological Survey, 1973, Water resources data for Puerto Rico, 1968, Part 1, Surface water records: U.S. Geological Survey Water-Data Report, 87 p. 


\section{Water-Data Reports--Continued}

U.S. Geological Survey, 1973, Water resources data for Puerto Rico, 1968, Part 2, Surface water records: U.S. Geological Survey Water-Data Report, 87 p.

U.S. Geological Survey, 1973, Water resources data for Puerto Rico, 1968-72, Part 3, Ground water records: U.S. Geological Survey Water-Data Report, 78 p.

U.S. Geological Survey, 1973, Water resources data for Puerto Rico, 1969, Part 1, Surface water records: U.S. Geological Survey Water-Data Report, 89 p.

U.S. Geological Survey, 1973, Water resources data for Puerto Rico, 1970, Part 1, Surface water records: U.S. Geological Survey Water-Data Report, 90 p.

U.S. Geological Survey, 1973, Water resources data for Puerto Rico, 1971, Part 1, Surface water records: U.S. Geological Survey Water-Data Report, $72 \mathrm{p}$.

U.S. Geological Survey, 1974, Water resources data for Puerto Rico, 1972, Part 1, Surface water records: U.S. Geological Survey Water-Data Report, 70 p.

U.S. Geological Survey, 1974, Water resources data for Puerto Rico, 1968-72, Part 2A, Water quality records: U.S. Geological Survey WaterData Report, 410 p.

U.S. Geological Survey, 1975, Water resources data for Puerto Rico, 1973, Part 1, Surface water records: U.S. Geological Survey Water-Data Report, 69 p.

U.S. Geological Survey, 1975, Water resources data for Puerto Rico, 1973, Part 2, Water quality records: U.S. Geological Survey Water-Data Report, 133 p.

U.S. Geological Survey, 1975, Water resources data for Puerto Rico, 1968-72, Part 2B, Water quality records (sediment): U.S. Geological Survey Water-Data Report, $182 \mathrm{p}$.

U.S. Geological Survey, 1976, Water resources data for Puerto Rico, 1974, Part 1, Surface water records: U.S. Geological Survey Water-Data Report, 66 p.

U.S. Geological Survey, 1976, Water resources data for Puerto Rico, 1974, Part 2, Water quality records: U.S. Geological Survey Water-Data Report, 158 p.

U.S. Geological Survey, 1978, Water resources data for Puerto Rico, Surface and quality-of-water records, Water Years 1975-76, Ground water records, Water Years 1973-76: U.S. Geological Survey Water-Data Report-PR-76-1, 366 p.

U.S. Geological Survey, 1980, Water resources data for Puerto Rico, Surface and quality-of-water records, Water Year 1977, Ground water records, Water Year 1977: U.S. Geological Survey Water-Data Report PR-77-1, 215 p.

U.S. Geological Survey, 1981, Water resources data for Puerto Rico, Water Year 1978: U.S. Geological Survey Water-Data Report PR-78-1, 255 p.

U.S. Geological Survey, 1982, Water resources data for Puerto Rico, Water Years 1979-80: U.S. Geological Survey Water-Data Report PR-79$80,408 \mathrm{p}$. 


\section{Abstracts, Articles, and Proceedings Papers}

Abstracts and Articles are condensed but informative summaries of presentations made at meeting of scientific and professional organizations. Typically they summarize the principal conclusions of an author's current work but contain little supporting data. These publications are not available from the U.S. Geological Survey.

Arnow, Ted, and Bogart, D.B., 1959, Water problems of Puerto Rico and a program of water-resources investigations: Transactions of the Second Caribbean Geological Conference, January 4-9, 1959, Mayagüez, Puerto Rico, p. 120-129.

Arroyo, I.E., Torres-González, Sigfredo, and Carrasquillo, R.A., 1990, A computer program for GEOphysical log data MANagement and plotting (GEOMAN): in Krishna, J.H., Quiñones-Aponte, Vicente, Gómez-Gómez, Fernando, and Morris, G.L., eds., Tropical Hydrology and Caribbean Water Resources, Proceedings of the International Symposium on Tropical Hydrology, San Juan, Puerto Rico, July 23-27, 1990, AWRA TPS-90-2, p. 395-401.

Collar, P.D., 1991, Fluvial metal transport during a storm event, Río Grande de Loíza basin, Puerto Rico [Abstract]: The Geological Society of America, Abstracts with Programs, v. 23, no. 5, p. 203.

Collar, P.D., and Guzmán-Ríos, Senén, 1991, Sedimentation rates and capacity restoration options, Lago Loíza, Puerto Rico: in Drs. Shou-Shan Fan and Yung-Huang Kuo, eds., Proceedings of the Fifth Federal Interagency Sedimentation Conference, Las Vegas, Nevada, March 18-21, 1991 , v. 2, p. $15-17$ to $15-25$.

Collar, P.D., Troester, J.W., Deike, R.G., and Robinson, P.D., 1990, Iron and manganese in alluvial ground water, Yabucoa, Puerto Rico: Proceedings of the Interamerican Association of Sanitary and Environmental Engineers Annual Meeting, v. 3, p. 708-732.

Conde-Costas, Carlos, and Troester, J.W., 1988, The effects of bat guano on carbonate chemistry in Cueva El Convento, Guayanilla, Puerto Rico [Abstract]: National Speleological Society, Forty-Fifth Annual Convention Program, Hot Spring, South Dakota, June 27 to July 1, 1988, p. 34.

Curtis, R.E., Jr., 1985, Floods of April 18, 1983 on St. Thomas and St. John, U.S. Virgin Islands: Proceedings of the Tropical Hydrology and Second Caribbean Islands Water-Resources Congress, May 5-8, 1985, American Water Resources Association, Technical Publication Series TPS-85-1, p. 90-95.

Ellins, K.K., Román-Más, Angel, and Lee, R.N., 1986, Estimating ground-water influx to a portion of the Río Grande de Manatí River basin in Puerto Rico through the measurement of ${ }^{222} \mathrm{Rn}$ : in Quiñones, Ferdinand, Sánchez, A.V., and Smith, H.H., eds., Proceedings of the Third Caribbean Islands Water-Resources Congress, U.S. Virgin Islands, July 22-25, 1986, Puerto Rico Water Resources Association, p. 27.

Gellis, Allen, 1990, Sediment loads in selected streams in Puerto Rico during the passage of Hurricane Hugo [Abstract]: The Geological Society of America, Abstracts with Programs, v. 22, no. 7, p. A331.

Gellis, Allen, 1991, Construction effects on sediment for two basins in Puerto Rico: in Drs. Shou-Shan Fan and Yung-Huang Kuo, eds., Proceedings of the Fifth Federal Interagency Sedimentation Conference, Las Vegas, Nevada, March 18-21, 1991, v. 1, p. 4-72 to 4-78.

Giusti, E.V., and López, M.A., 1967, Climate and streamflow of Puerto Rico: Caribbean Journal of Science, September-December, 1967, v. 7, no. 3-4, p. 87-93.

Gómez-Gómez, Fernando, 1990, Hydrochemistry of the South Coastal Plain Aquifer System of Puerto Rico and its relation to surface-water recharge: in Gómez-Gómez, Fernando, Quiñones-Aponte, Vicente, and Johnson, A.I., eds., Aquifers of the Caribbean Islands, Proceedings of the International Symposium on Tropical Hydrology, San Juan, Puerto Rico, July 23-27, 1990, AWRA Monograph Series no. 15, p. 57-75.

Grossman, I.G., 1966, Fluctuations of ground-water levels in Puerto Rico resulting from earthquakes (1959-1961) [Abstract]: Transactions of the Third Caribbean Geological Conference, Kingston, Jamaica, April 1962, p. 104-105.

Larsen, M.C., 1989, Use of seismic refraction techniques for investigating morphology of recent landslides in a tropical rain forest in Puerto Rico [Abstract]: The Geological Society of America, Abstracts with Programs, v. 21, no. 3, p. 46.

Larsen, M.C., 1990, Landslides and pore pressure responses associated with Hurricane Hugo, September 1989, eastern Puerto Rico [Abstract]: The Geological Society of America, Abstracts with Programs, v. 22, no. 7, p. A331.

Larsen, M.C., 1990, Landslides caused by the intense precipitation of Hurricane Hugo in El Yunque and surrounding areas: Boletín Oficial de la Sociedad de Historia Natural de Puerto Rico, v. 24, no. 12, p. 8.

Larsen, M.C., 1990, Landslides caused by the intense precipitation of Hurricane Hugo, September 1989, eastern Puerto Rico [Abstract]: EOS, Transactions, American Geophysical Union, v. 71, no. 6., p. 259.

Larsen, M.C., 1991, Mass wasting disturbance and denudation in a humid-tropical montane forest, Puerto Rico [Abstract]: The Geological Society of America, Abstracts with Programs, v. 23, no. 5, p. A256. 


\section{Abstracts, Articles, and Proceedings Papers--Continued}

Larsen, M.C., and Simon, Andrew, 1990, Landslide processes in saprolitic soils of a tropical rain forest, Puerto Rico: in Larue, D.K., and Draper, G., eds., Transactions of the 12th Caribbean Geological Conference, St. Croix, U.S. Virgin Islands, Miami Geological Society, p. $217-222$.

Larsen, M.C., and Simon, Andrew, 1992, A rainfall intensity-duration threshold relation for landslide occurrence in the humid-tropical environment of Puerto Rico [Abstract]: The Geological Society of America, Abstracts with Programs, v. 24, no. 7, p. A166.

Larsen, M.C., and Torres-Sánchez, A.J., 1990, Rainfall-soil moisture relations in landslide-prone areas of a tropical rain forest, Puerto Rico: in Krishna, J.H., Quiñones-Aponte, Vicente, Gómez-Gómez, Fernando, and Morris, G.L., eds., Tropical Hydrology and Caribbean Water Resources, Proceedings of the International Symposium on Tropical Hydrology, San Juan, Puerto Rico, July 23-27, 1990, AWRA TPS-90-2, p. 121-129.

Larsen, M.C., and Torres-Sánchez, A.J., 1992, Landslides triggered by Hurricane Hugo in eastern Puerto Rico, September 1989: Caribbean Journal of Science, v. 28, no. 3-4, p. 113-125.

Menoyo, L.E., 1992, Using a microcomputer to create an animated three-dimensional visualization of Bahra de Añasco, Puerto Rico [Abstract]: Joint U.S. Geological Survey/Jet Propulsion Laboratory Scientific Visualization Workshop, Program and Abstracts, Norfolk, Virginia, May 1819,1992, p. 22.

Puig, J.C., Rolón-Collazo, L.I., and Pagán-Trinidad, Ismael*, 1990, Development of an aquifer management model: AQMAN3D: in Krishna, J.H., Quiñones-Aponte, Vicente, Gómez-Gómez, Fernando, and Morris, G.L., eds., Tropical Hydrology and Caribbean Water Resources, Proceedings of the International Symposium on Tropical Hydrology, San Juan, Puerto Rico, July 23-27, 1990, AWRA TPS-90-2, p. 39-48.

Quiñones-Aponte, Vicente, 1987, Effects of the channelization of Río Bucaná on the ground-water resources north of the Ponce Valley, Puerto Rico; Numerical analysis: Proceedings of the 12th Natural Resources Symposium, San Juan, Puerto Rico, December 11-12, 1985, Puerto Rico Department of Natural Resources (Published in Spanish), 4 p.

Quiñones-Aponte, Vicente, 1988, Effects of the horizontal anisotropy on the determination of storage coefficient [Abstract]: International Conference on Advances in Ground-Water Hydrology, Tampa, Florida, November 16-18, 1988, American Institute of Hydrology.

Quiñones-Aponte, Vicente, 1989, Comparison of aquifer storage coefficients computed using anisotropic and isotropic analytical models: Proceedings of the Recent Advances in Ground-Water Hydrology, American Institute of Hydrology, p. 349-357.

Quiñones-Aponte, Vicente, 1989, Horizontal Anisotropy of the principal ground-water flow zone in the Salinas alluvial fan, Puerto Rico: Ground Water Journal, v. 27, no. 4, p. 491-500.

Quiñones-Aponte, Vicente, 1989, Hydrogeologic characteristics of the lower Río Grande de Arecibo alluvial valley: Proceedings of the 13th Natural Resources Symposium, San Juan, Puerto Rico, February 26, 1987, Puerto Rico Department of Natural Resources, p. 41-59.

Quiñones-Aponte, Vicente, 1988, Recovery efficiency from single-well injection/recovery tests in a limestone aquifer of high secondary porosity: Proceedings of the American Society of Civil Engineers, Irrigation and Drainage Division, Artificial Recharge of Ground Water, International Symposium, Anaheim, California, August 1988, p. 54-64.

Quiñones-Aponte, Vicente, 1991, Water-resources development and its influence on the water budget for the aquifer system in the Salinas to Patillas area, Puerto Rico: in Gómez-Gómez, Fernando, Quiñones-Aponte, Vicente, and Johnson, A.I., eds., Aquifers of the Caribbean Islands, Proceedings of the International Symposium on Tropical Hydrology, San Juan, Puerto Rico, July 23-27, 1990, AWRA Monograph Series no. 15 , p. $37-55$.

Quiñones-Aponte, Vicente, and Carrasquillo, R.A., 1986, Use of borehole neutron logs to estimate moisture content in the unsaturated zone of an alluvial aquifer: in Quiñones, Ferdinand, Sánchez, A.V., and Smith, H.H., eds., Proceedings of the Third Caribbean Islands WaterResources Congress, U.S. Virgin Islands, July 22-25, 1986, Puerto Rico Water Resources Association, p. 57-60.

Quiñones-Aponte, Vicente, and Torres-Sierra, Heriberto, 1985, Application of a ground-water flow digital model in evaluating alternate dewatering systems in the Río Grande de Arecibo alluvial valley, Puerto Rico: Proceedings of the Tropical Hydrology and Second Caribbean Islands Water-Resources Congress, May 5-8, 1985, American Water Resources Association, Technical Publication Series TPS-85-1, p. 129134.

Renken, R.A., Barker, R.A., and Gómez-Gómez, Fernando, 1990, Basin analysis, paleoenvironment reconstruction and tectonic structures: Application of geologic interpretations to regional ground-water assessment in large sedimentary basins: Proceedings of the International Conference on Ground Water in Large Sedimentary Basins, Australia Water-Resources Council Conference Series no. 20, Perth, Western Australia, July 9-13, 1990, p. 80-88. 


\section{Abstracts, Articles, and Proceedings Papers--Continued}

Renken, R.A., Gómez-Gómez, Fernando, Quiñones-Aponte, Vicente, and Dacosta, Rafael, 1991, Structure and depositional patterns and their influence on the hydraulic conductivity of fan-deltas in southern Puerto Rico: in Gómez-Gomez, Fernando, Quiñones-Aponte, Vicente, and Johnson, A.I., eds., Aquifers of the Caribbean Islands, Proceedings of the International Symposium on Tropical Hydrology, San Juan, Puerto Rico, July 23-27, 1990, AWRA Monograph Series no. 15, p. 25-36.

Richards, R.T., Troester, J.W., 1992, Using surface geophysical techniques to map the saline-freshwater interface and the depth to bedrock in the Valle de Yabucoa alluvial aquifer, Puerto Rico [Abstract]: Proceedings of the 17th Symposium of Natural Resources, San Juan, Puerto Rico, November 1991.

Rodríguez-Martínez, Jesús, 1991, The hydrogeologic framework of the Northern Coastal Province Aquifer System of Puerto Rico: in GómezGómez, Fernando, Quiñones-Aponte, Vicente, and Johnson, A.I., eds., Aquifers of the Caribbean Islands, Proceedings of the International Symposium on Tropical Hydrology, San Juan, Puerto Rico, July 23-27, 1990: AWRA Monograph Series no. 15, p. 5-16.

Rolón-Collazo, L.I., and González, Philip, 1990, An interactive computer program, GWARC, to create a geographic information system data set from ground-water site inventory data [Abstract]: National Computer Technology Meeting, May 7-11, 1990, Programs and Abstracts, U.S. Geological Survey Open-File Report 90-161, p. 34.

Román-Más, Angel, 1986, Role of blanket deposits on the hydrology and water chemistry of the limestone water-table aquifer within the north coast of Puerto Rico through interpretation of geochemical data: in Quiñones, Ferdinand, Sánchez, A.V., and Smith, H.H., eds., Proceedings of the Third Caribbean Islands Water-Resources Congress, U.S. Virgin Islands, July 22-25, 1986, Puerto Rico Water Resources Association, p. 33.

Román-Más, Angel, 1986, Role of climatic data in determining the water required, used, and supplied for irrigation in the rice-growing areas along the north coast of Puerto Rico [Abstract]: Conference on Climate and Water Management - A Critical Era, American Meteorological Society, August 4-7, 1986, p. 1-9.

Román-Más, Angel, and Lee, R.W., 1985, Water quality and chemical evolution of ground water within the north coast limestone aquifers of Puerto Rico: Proceedings of the Tropical Hydrology and Second Caribbean Islands Water-Resources Congress, May 5-8, 1985, American Water Resources Association, Technical Publication Series TPS-85-1, p. 57-63.

Scatena, F.N., and Larsen, M.C., 1991, Physical aspects of Hurricane Hugo in Puerto Rico: Biotropica, v. 23 , no. 4A, p. $317-323$.

Sepulveda, Nicasio, 1991, Solution of the one-dimensional consolidation theory equation with a Pseudospectral Method: Proceedings of the Fourth International Association of Hydrological Sciences, Symposium on Land Subsidence, Houston, Texas, IAHS no. 200 , p. 555-564.

Sepulveda, Nicasio, and Zack, A.L., 1990, Laboratory simulation of the effects of overburden stress on the specific storage of shallow artesian aquifers: in Krishna, J.H., Quiñones-Aponte, Vicente, Gómez-Gómez, Fernando, and Morris, G.L., eds., Tropical Hydrology and Caribbean Water Resources, Proceedings of the International Symposium on Tropical Hydrology, San Juan, Puerto Rico, July 23-27, 1990, AWRA TPS-90-2, p. 349-356.

Simon, Andrew, and Larsen, M.C., 1988, Shear strength and slope stability at sites in the Caribbean National Forest and Coamo area, Puerto Rico [Abstract]: The Geological Society of America, Abstracts with Programs, v. 20, no. 7, p. A144.

Simon, Andrew, Larsen, M.C., and Hupp, C.R., 1990, The role of soil processes in determining mechanisms of slope failure and hillslope development in a himid-tropical forest, eastern, Puerto Rico: in Kneupfer , P.L.D. and McFadden, L.D., eds., Soils and Landscape Evolution, Geomorphology, 3(1990), p. 263-286.

Torres-González, Arturo, 1981, Hydrology of the Río Camuy caves system, Puerto Rico [Abstract]: Proceedings of the Eighth International Congress of Speleology, July 18-24, 1981, Kentucky, no. 8, p. 475.

Torres-González, Sigfredo, 1984, Water-resources investigations of Vieques Island, Puerto Rico: Proceedings of the First Caribbean Islands Water Resources Congress, St. Thomas, U.S. Virgin Islands, July 26-27, 1984, p. 298-311.

Torres-González, Sigfredo, 1991, Steady-state simulation of ground-water flow conditions in the Kingshill aquifer, St. Croix, U.S. Virgin Islands, July 1987: in Gómez-Gómez, Fernando, Quiñones-Aponte, Vicente, and Johnson, A.I., eds., Aquifers of the Caribbean Islands, Proceedings of the International Symposium on Tropical Hydrology, San Juan, Puerto Rico, July 23-27, 1990, AWRA Monograph Series no. 15, p. 93-108.

Torres-González, Sigfredo, and Rolón-Collazo, L.I., 1990, The interactive computer program MODUMANAG, a data management tool for the modular finite-difference ground-water flow model: in Krishna, J.H., Quiñones-Aponte, Vicente, Gómez-Gómez, Fernando, and Morris, G.L., eds., Tropical Hydrology and Caribbean Water Resources, Proceedings of the International Symposium on Tropical Hydrology, San Juan, Puerto Rico, July 23-27, 1990, AWRA TPS-90-2, p. 403-410. 


\section{Abstracts, Articles, and Proceedings Papers--Continued}

Torres-Sierra, Heriberto, 1986, Estimated water use in St. Croix, U.S. Virgin Islands, 1983-1985: in Quiñones, Ferdinand, Sánchez, A.V., and Smith, H.H., eds., Proceedings of the Third Caribbean Islands Water-Resources Congress, U.S. Virgin Islands, July 22-25, 1986, Puerto Rico Water Resources Association, p. 7-11.

Troester, J.W., 1990, Hydrogeologic processes in the northern karst belt of Puerto Rico: A humid tropical karst [Abstract]: Proceedings of the International Symposium and Field Seminar on Hydrogeologic Processes in Karst Terranes, Antalya, Turkey, October 7-17, 1990 , p. $116-117$.

Troester, J.W., 1992, Wind as a hydrogeologic agent and cultural factor in the Lesser Antilles [Abstract]: The Geologic Society of America, Abstracts with Programs, v. 24, no. 7, p. A68.

Troester, J.W., 1992, The northern karst belt of Puerto Rico: A Humid Tropical Karst: in Back, William, Herman, J.S., and Paloc, Henri, eds., Hydrogeology of Selected Karst Regions, International Association of Hydrogeologists, v. 13, p. 475-486.

Troester, J.W., and Moore, J.E., 1989, Karst hydrogeology in the United States of America: Episodes, v. 12, no. 3, p. $172-178$.

Troester, J.W., and White, W.B., 1988, River knickpoints, uplift, and tilting in the northern karst belt of Puerto Rico [Abstract]: The Geological Society of America, Abstracts with Programs, v. 20, no. 7, p. 307.

Troester, J.W., and White, W.B., 1988, The carbonate chemistry of the Río Camuy drainage basin, Puerto Rico: A Humid Tropical Karst [Abstract]: National Speleological Society, Annual Convention Program, p. 34.

Troester, J.W., and White, W.B., 1989, Carbonate chemistry and hydrogeology of Río Camuy drainage basin, Puerto Rico [Abstract]: Humid Tropical Karst 28th International Geologic Congress, Washington D.C., July 9-19, 1989, v. 3, p. 255.

Troester, J.W., Back, William, and Mora, S.C., 1987, Karst of the Caribbean: in Graf, W.L., Geomorphic Systems of North America: The Geological Society of America, DNAG (Decade of North American Geology) Centennial Special Volume no. 2, p. 343-402.

Troester, J.W., Collar, P.D., Robinson, P.D.*, and Deike, R.G., 1990, Geochemical processes controlling manganese and iron concentrations in the ground water of the Valle de Yabucoa alluvial aquifer, Puerto Rico [Abstract]: EOS, Transactions, American Geophysical Union, April 24, 1990 , v. 71 , no. 17 , p. 506.

Troester, J.W., Deike, R.G., Robinson, P.D.*, and Collar, P.D., 1990, Petrographic analyses and geochemical modeling of aquequs/solid phase reactions in the Valle de Yabucoa alluvial aquifer, Puerto Rico [Abstract]: The Geological Society of America, Abstracts with Programs, p. A295.

Yuan, Daoxian, and Troester, J.W., 1990, Evidence of climatic control on hydrogeologic processes in the karst terranes of Central China and Puerto Rico [Abstract]: Proceedings of the International Symposium and Field Seminar on Hydrogeological Processes in Karst Terranes, Antalya, Turkey, October 7-17, 1990, p. 120-121.

Whitesides, D.V., Quiñones-Aponte, Vicente, and Zack, A.L., 1985, Estimating the capacity of a salty limestone aquifer in Puerto Rico to receive, store, and release injected freshwater using chloride mass balance: Proceedings of the Second Caribbean Islands Water-Resources Congress and Tropical Hydrology, May 5-8, 1985, American Water Resources Association, Technical Publication Series TPS-85-1, p. 50-55.

Zack, Allen, 1984, Use of scavenger-production well couples to optimize withdrawal of freshwater from saline aquifers in Puerto Rico: Proceedings of the First Caribbean Islands Water-Resources Congress, St. Thomas, U.S. Virgin Islands, July 26-27, 1984, p. 312-336.

Zack, Allen, 1986, Effects of sand removal on the shallow aquifer in the vicinity of the Camuy Mangrove Forest, Puerto Rico: in Quiñones, Ferdinand, Sánchez, A.V., and Smith, H.H., eds., Proceedings of the Third Caribbean Islands Water-Resources Congress, U.S. Virgin Islands, July 22-25, 1986, Puerto Rico Water Resources Association, p. 41-48.

Zack, Allen, and Román-Más, Angel, 1988, Hydrology of the Caribbean Islands Wetlands: Proceedings of the Caribbean Islands Wetlands Workshop, Forestry \& Wildlife Management Institute, University of Massachusetts at Amherst, October 28-29, 1986, p. 65-73. 


\section{REPORTS IN PREPARATION}

For the reader's information a list of approved reports pending publication is included. As these reports are completed and printed, they will be available for distribution. They are listed alphabetically by author.

Graves, R.P., In press, Hydrogeology of south-central St. Croix, U.S. Virgin Islands: U.S. Geological Survey Water-Resources Investigations Report 93-465.

Green, B.K., and Cherry, Gregory, In press, Water wells on St. Croix, U.S. Virgin Islands: U.S. Geological Survey Open-File Report 91-503.

Larsen, M.D., Collar, P.D., and Stallard, R.F., In press, Research plan for the investigation of water, energy, and biogeochemical budgets in the Luquillo Mountains, Puerto Rico: U.S. Geological Survey Open-File Report 92-150.

Puig, J.C., and Rolón-Collazo, Lourdes, In press, User's manual for AQMAN3D, a mathematical programming system dataset generator for aquifer management using the U.S. Geological Survey modular three-dimensional finite-difference ground-water flow model: U.S. Geological Survey Open-File Report 92-481.

Ramos-Ginés, Orlando, In press, Hydrology, water quality, and potential alternatives for water-resources development in the Río Majada and Río Lapa basins, southern Puerto Rico: U.S. Geological Survey Water-Resources Investigations 91-4174.

Ramos-Ginés, Orlando, In press, Effects of changing irrigation practices on the ground-water hydrology of the Santa Isabel-Juana Díaz area, south central Puerto Rico: U.S. Geological Survey Water-Resources Investigations 91-4183.

Rodríguez-Martínez, Jesús, and Hartley, J.L., In press, Geologic and hydrologic data collected at test holes NC-6 and NC-11, Hatillo and Isabela, northwestern Puerto Rico: U.S. Geological Survey Open-File Report 93-465.

Rodríguez-Martínez, Jesús, and Scharlach, R.A., In press, Geologic and hydrologic data collected at test hole NC-8, Vega Alta, Puerto Rico: U.S. Geological Survey Open-File Report 93-466.

Santiago-Rivera, Luis, and Quiñones-Aponte, Vicente, In press, Hydrology of Laguna Joyuda, Puerto Rico: U.S. Geological Survey WaterResources Investigations 93-4135.

Steiger, J.I., and Kessler, Richard, In press, Water wells on St. Johns, U.S. Virgin Islands: U.S. Geological Survey Open-File Report 92-131.

Steiger, J.I., and Kessler, Richard, In press, Water wells on St. Thomas, U.S. Virgin Islands: U.S. Geological Survey Open-File Report 91-504. 


\section{AUTHOR INDEX}

The Author Index was prepared using the "List of Publications by Authors" section. 


\section{AUTHOR INDEX}

\section{A}

ADOLPHSON, D.G.

AKERS, J.P.

ALICEA, J.

$23,25,29$

ANDERS, R.B.

16,28

ANDERSON, H.R.

....16

AQUINO, $\mathrm{Z}$.

ARNOW, T.

. .18

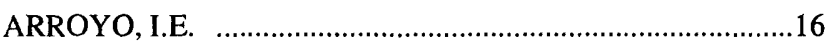

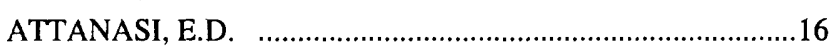

AVILÉS, A.

\section{B}

BACK, W. .31

BARKER, R.A. ..................................................... 27

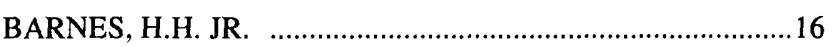

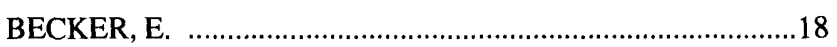

BENNETT, G.D. ...............................................16, 19

BOGART, D.B. ...................................................16, 17, 21

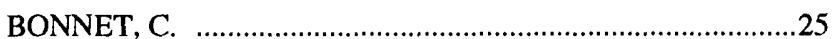

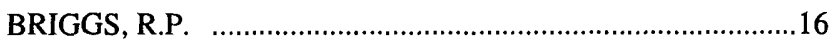

\section{C}

CANOY, M.

CARRASQUILLO, R.A.

CEDERSTROM, D.J.

$16,22,23,26$

CLASS-CACHO, A.

CLOSE, E.R

COBB, E.D.

COLLAR, P.D.

17,24

COLÓN-DIEPPA, E.

COLÓN-RAMOS, H.M.

CONDE-COSTAS, C.

COSNER, O.J.

CROOKS, J.W.

CRUZ, $\mathrm{C}$.

CURTIS, R.E., JR.

$.17,31$

$17,24,25,29$

...17, 18

....17

17,23

$16,17,21$

...22

$.17,18$

D

DACOSTA, $R$.

$18,20,27,30$

DEIKE, R.G.

DÍAZ, J.R.

$.17,31$

DÍAZ, P.L.

$18,21,24,29$

$17,18,27$

DURFOR, C.N.

DURUM, W.H.

E

ELLIS, S.R.

19,20

ELLINS, K.K

\section{F}

FIELDS, F.K.

19,24

FIGUEROA-ALAMO, C. ...................................................... 19

FISHER, D.W. .

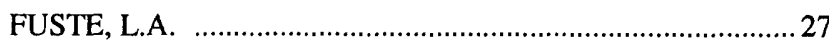

G

GARCÍA, R. .

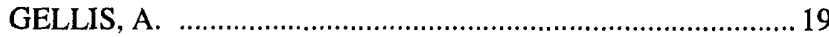

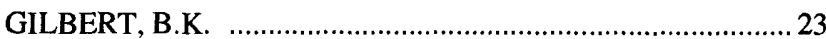

GIUSTI, E.V. ........................................................16, 19

GOMEZ-GOMEZ, F. ................... 18, 19, 20, 26, 27, 28, 29, 30

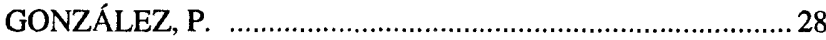

GONZÁLEZ, R. ........................................... 17, 20, 22, 23

GONZÁLEZ, J.R. ....................................................... 17, 22

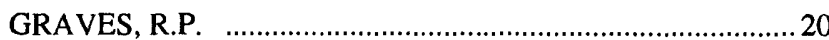

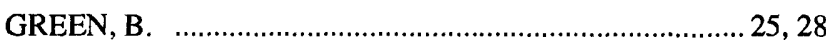

GROSSMAN, I.G. ...............................................17, 20, 21

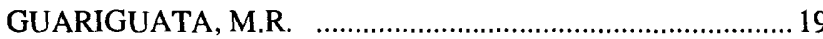

GUZMÁN-RÍOS, S. .....................................18, 18, 20, 21, 27

H

HAIRE, W.J.

21,22

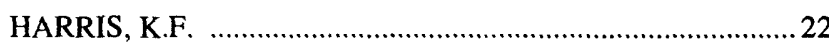

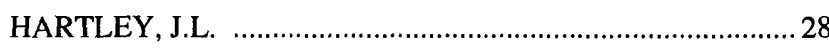

HEIDEL, S.G. . ...................................................... 18, 32

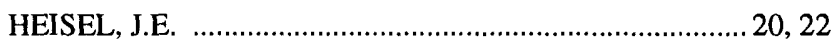

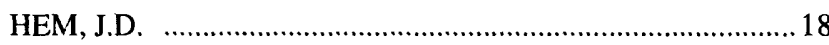

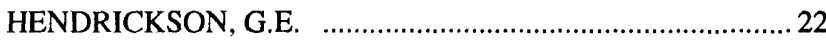

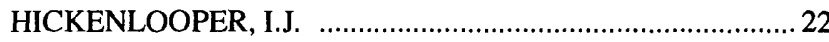

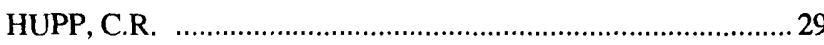

I

ISERI, K.T.

32

J

JOHNSON, K.G.

$21,22,23,25$

JORDAN, D.G. ............................................18, 19, 23, 32

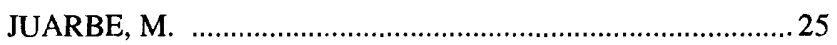

K

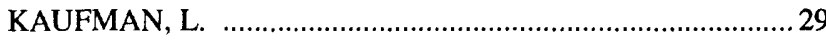

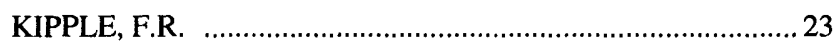

$\mathbf{L}$

LARSEN, M.C.

$21,23,29$

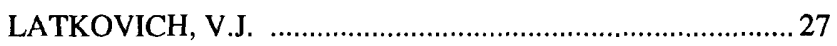

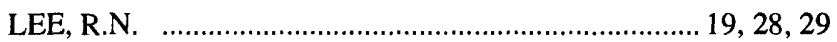

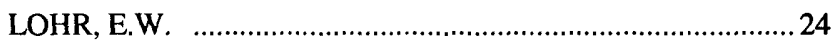

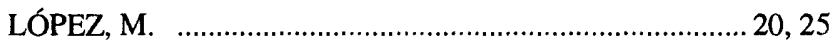

LÓPEZ, M.A. ………………………………....16, 19, 22, 24 


\section{AUTHOR INDEX--Continued}

$\mathbf{M}$

MANSUE, L.J. .17

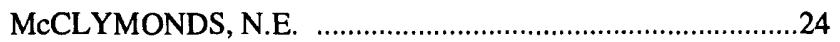

McCOY, J.H. ........................................................ 24

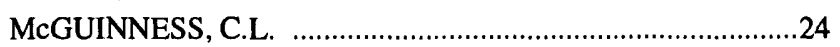

McKINLEY, P.W. ....................................................18, 24

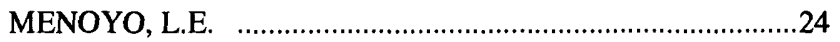

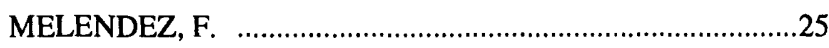

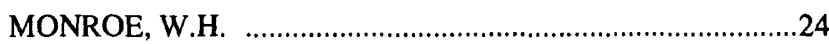

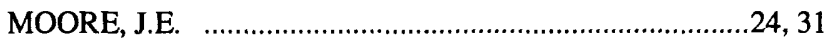

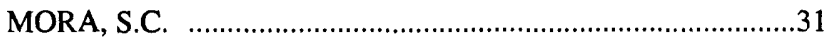

o

ORONA, M. . .20

ORTÍZ, J.

\section{$\mathbf{P}$}

PAGAN-TRINIDAD, I.

.25

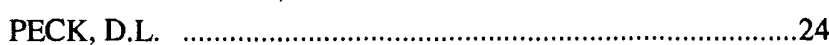

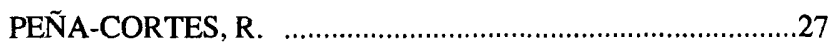

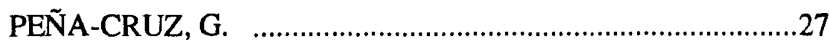

PUIG, J.C.

24,25

Q

QUIÑONES, F.

$20,23,25$

QUIÑONES-APONTE, $V$.

QUIÑONES-MÁRQUEZ, F.

$17,22,25,26,27,28,32$

$17,20,21,26,27$

R

RAMOS-GINÉS, $\mathrm{O}$.

$.27,29$

REID, $\mathrm{K}$.

RENKEN, R.A.

RICHARDS, R.T.

. .27

RICKLER, J.G.

RIVERA, E.

....27

$.27,28$

ROBINSON, P.D.

17,31

ROBISON, T.M.

$.16,28$

RODRÍGUEZ, J.M.

$.24,25$

RODRÍGUEZ-ALONSO, T

$.32,33$

RODRÍGUEZ-DEL-RÍO, F.

RODRÍGUEZ-MARTÍNEZ, J.

ROLÓN-COLLAZO, L.I.

ROMAN-MÁS, A.
$\mathbf{S}$

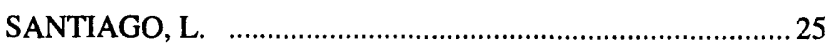

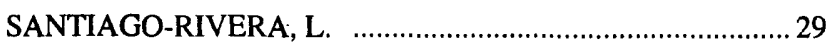

SCATENA, F.N. .................................................................. 29

SCHARLACH, R.A. ............................................................... 28

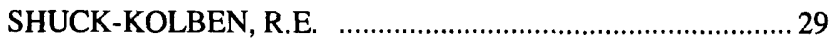

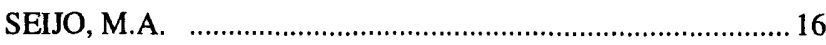

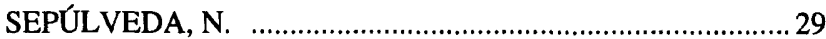

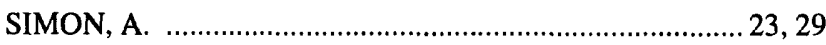

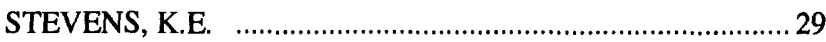

$\mathbf{T}$

TORRES-GONZÁLEZ, A.

$28,29,30$

TORRES-GONZÁLEZ, S.

TORRES-SÁNCHEZ, A.J.

16,30

TORRES-SIERRA, $\mathrm{H}$.

$17,20,26,30$

TROESTER, J.W.

TRUXES, C.S.

$17,24,27,30,31,32$

$\mathbf{U}$

U.S. GEOLOGICAL SURVEY

31,32

\section{V}

VACHIER, R. .18

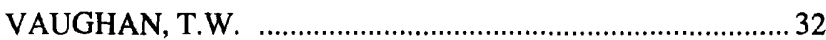

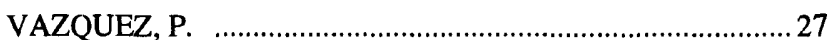

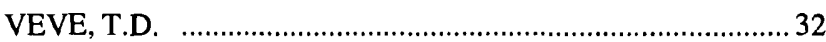

W

WARD, P.E.

WHITE, W.B. ................................................................... 31

WHITESIDES, D.V. .................................................... 26, 32

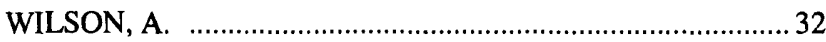

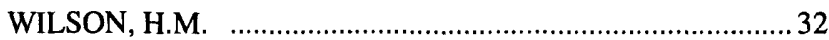

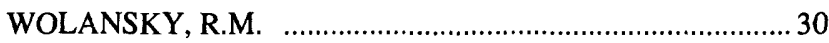

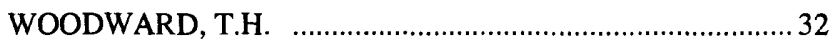

$Y$

YUAN, D.

32

$\mathbf{Z}$

ZACK, A.L.

$20,26,27,29,32,33$ 